\title{
Het nut van comparatieve begrippen : een studie omtrent de toepassing van begrippen in de rechtsvergelijking
}

Citation for published version (APA):

van Laer, C. J. P. (1997). Het nut van comparatieve begrippen : een studie omtrent de toepassing van begrippen in de rechtsvergelijking. [Doctoral Thesis, Maastricht University]. Intersentia. https://doi.org/10.26481/dis.19970613cl

Document status and date:

Published: 01/01/1997

DOI:

10.26481/dis.19970613cl

Document Version:

Publisher's PDF, also known as Version of record

Please check the document version of this publication:

- A submitted manuscript is the version of the article upon submission and before peer-review. There can be important differences between the submitted version and the official published version of record.

People interested in the research are advised to contact the author for the final version of the publication, or visit the DOI to the publisher's website.

- The final author version and the galley proof are versions of the publication after peer review.

- The final published version features the final layout of the paper including the volume, issue and page numbers.

Link to publication

\footnotetext{
General rights rights.

- You may freely distribute the URL identifying the publication in the public portal. please follow below link for the End User Agreement:

www.umlib.nl/taverne-license

Take down policy

If you believe that this document breaches copyright please contact us at:

repository@maastrichtuniversity.nl

providing details and we will investigate your claim.
}

Copyright and moral rights for the publications made accessible in the public portal are retained by the authors and/or other copyright owners and it is a condition of accessing publications that users recognise and abide by the legal requirements associated with these

- Users may download and print one copy of any publication from the public portal for the purpose of private study or research.

- You may not further distribute the material or use it for any profit-making activity or commercial gain

If the publication is distributed under the terms of Article $25 \mathrm{fa}$ of the Dutch Copyright Act, indicated by the "Taverne" license above, 
Het nut van comparatieve begrippen 
Ius Commune Europaeum

Van dit proefschrift verschijnt een bandelseditie in de Ius Commune Europaeum Reeks onder ISBN 9050950086 


\section{Het nut van comparatieve begrippen}

Een studie omtrent de toepassing van begrippen in de rechtsvergelijking

\section{PROEFSCHRIFT}

ter verkrijging van de graad van doctor

aan de Universiteit Maastricht,

op gezag van de Rector Magnificus, Prof.mr. M.J. Cohen,

volgens het besluit van het College van Decanen,

in het openbaar te verdedigen op

vrijdag 13 juni 1997 om 16.00 uur

door

Conrad Jean Pierre van Laer 
Promotores: $\quad$ Prof.mr. G.-R. de Groot

Prof.mr. N.H.M. Roos

Beoordelingscommissie: Prof.mr.drs. G.E. van Maanen (voorzitter)

Prof.dr. J. Dumortier (Katholieke Universiteit Leuven)

Prof.dr. D. Kokkini-Iatridou (Universiteit Utrecht)

Prof.dr. G.W. Mincke 


\section{Voorwoord}

$\mathrm{Na}$ het schrijven van een proefschrift past eerder een dankwoord dan een voorwoord. Vooreerst dank ik mijn promotor Prof.mr. G.-R. de Groot die mij eind 1990 heeft gevraagd om een proefschrift te schrijven: daaraan heb ik meestal met veel plezier gewerkt. Zijn voorstel en zijn werkplan hebben geleid tot een spannende ontdekkingstocht. Dat ik niet in vruchteloze bespiegelingen bleef steken, is te danken aan promotor Prof.mr. N.H.M. Roos. Zijn trefzekere kritiek heeft mij in staat gesteld om een eigen standpunt te formuleren ten opzichte van de opvattingen in de literatuur.

Prof.mr.drs. G.E. van Maanen, Prof.dr. J. Dumortier, Prof.dr. D. Kokkini-latridou en Prof.dr. G.W. Mincke dank ik hartelijk voor hun werkzaamheden als leden van de beoordelingscommissie.

Een stimulerende gedachtewisseling heeft plaatsgevonden met: Prof.dr. H. Kötz (Hamburg), W.A.F.P. Steiner (Cambridge, UK) en mr.drs. A.E. Oderkerk (Amsterdam). Van hun deskundigheid heb ik veel opgestoken.

Velen in de Faculteit der Rechtsgeleerdheid van dle Universiteit Maastricht hebben mij inspiratie en advies gegeven. Dit geldt wooral voor de medewerkers van de vakgroep privaatrecht. Ook L. Rayar B.tr. ben ik erkentelijk voor has zorgvuldige vertaling van de Nederlandse samenvatting in het Engels.

De Universiteitsbibliotheek Maastricht is de bakermat van dit proefschrift: mijn eerste taak als bibliotheekmedewerker was het ontwerpen van een onderwerpsindeling voor diverse rechtsstelsels. Als bibliotheekgebruiker kon ik profiteren van de laatste voorzieningen op het gebied van literatuuronderzoek. Ook de uitstekende samenwerking binnen 
de UB heeft een positieve invloed gehad op mijn proefschrift. Bibliothecaris J.D. Gilbert, native speaker, heeft de summary gecorrigeerd. Collega Jacqueline Klinkeberg heeft zich met grote inzet gewijd aan het drukklaar maken van het manuscript.

Dit proefschrift is niet in dienstbetrekking geschreven, maar als een vrijetijdsbesteding. Deze bezigheid is zo nu en dan uit de hand gelopen. Niettemin heeft mijn vrouw Cor mij haar emotionele steun en gezonde scepsis niet onthouden. Mijn zonen Tom en Frank hebben mij gelukkig slechts af en toe gevraagd waarom ik nog steeds met dat boek bezig was.

Het manuscript is eind 1996 afgesloten. De nieuwe spellingsregels zijn zoveel mogelijk gevolgd.

Meerssen, maart 1997 


\section{Inhoudsopgave}

Voorwoord $\ldots \ldots \ldots \ldots \ldots \ldots \ldots \ldots \ldots \ldots \ldots \ldots \ldots \ldots \ldots \ldots$

Inhoudsopgave $\ldots \ldots \ldots \ldots \ldots \ldots \ldots \ldots$ vii

\section{Hoofdstuk I}

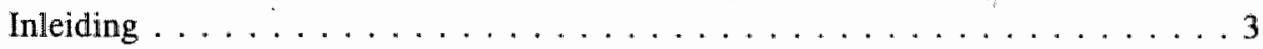

\section{Hoofdstuk II}

De problematiek van de comparatieve begrippen $\ldots \ldots \ldots . . \ldots$

$\S 1$. Soortbegrippen en typebegrippen $\ldots \ldots \ldots \ldots \ldots$

$\$ 2$. Verondersteld nut van comparatieve begrippen $\ldots \ldots \ldots \ldots \ldots \ldots$
A. DiRECT nUt . . . . . . . . . . . . . . . . . 12

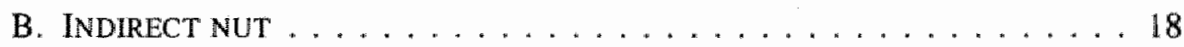

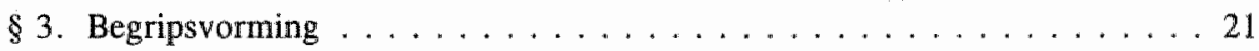

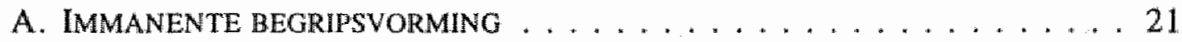
B. EXTENSIONELE BEGRIPSVORMING $\ldots \ldots \ldots \ldots \ldots \ldots \ldots \ldots \ldots$
C. FUnCTIONELE BEGRIPSVORMING $\ldots \ldots \ldots \ldots \ldots \ldots \ldots$

\$ 4. Rechtstermen voor comparatieve begrippen . . . . . . . . . . 30

A. VERSCHILLEN IN GEBRUIK .................. . . 30 


\section{Hoofdstuk III}

Mogelijk nut van comparatieve begrippen $\ldots \ldots \ldots \ldots \ldots$

$\$ 1$. Aanpak voor dit hoofdstuk $\ldots \ldots \ldots \ldots \ldots \ldots$

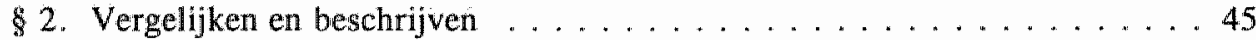

A. Comparatieve begrippen IN de beginfase . . . . . . . . . 45

B. Comparatieve BEgripPEn IN DE eINdfFASE . . . . . . . . . . . . 49

\$. Toetsing van vergelijkbaarheidsoordelen . . . . . . . . . . . 53

A. VERGELIJKBAARHEIDSOORDELEN MET FUNCTIEBEGRIPPEN . . . . . . 53

B. VERGELIJKBAARHEIDSOORDELEN MET IMMANENTE BEGRIPPEN $\ldots \ldots 56$

\$4. Presentatie van onderzoeksresultaten . . . . . . . . . . . . . 59

A. RECHTSVERGELIJKENDE CLASSIFICATIESYSTEMEN . . . . . . . . 59

B. EENDUIDIGE TERMINOLOGIE . . . . . . . . . . . . . 62

$\$ 5$. Comparatieve begrippen in de toepassingsgebieden $\ldots \ldots \ldots 66$

A. RECHTSVERGELUKING ALS HULPMIDDEL . . . . . . . . . . . . 66

B. BEPERKINGEN IN DE TOEPASSINGSGEBIEDEN . . . . . . . . . 68

\section{Hoofdstuk IV}

Rechtsvergelijkende ordeningssystemen $\ldots \ldots \ldots \ldots \ldots \ldots \ldots$. . . . . .

$\$ 1$. De constructie van een ordeningssysteem $\ldots \ldots \ldots \ldots \ldots 71$

A. INDELEN VAN BEGRIPPEN . . . . . . . . . . . . . 71

B. KEUZE VAN INDELINGSKARAKTERISTIEKEN $\ldots \ldots \ldots \ldots \ldots 75$

\$2. Juridische ordeningssystemen . . . . . . . . . . . . 78

A. KLASSEREN VAN JURIDISCHE DOCUMENTEN . . . . . . . . . . 78

B. RECHTSGEBIEDEN EN POLYHIËRARCHIE . . . . . . . . . . 81

C. OPVOLGINGSKARAKTERISTIEKEN . . . . . . . . . . 83 
\$ 3. Rechtsvergelijkende ordeningssystemen . . . . . . . . . . . 85

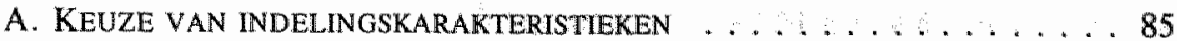

B. SELECTIE VAN GEMEENSCHAPPELIJKE KENMERKEN . . . . . . . . . . . 89

C. DE EXTENSIE VAN RECHTSVERGELJJKENDE CLASSIFICATIEBEGRIPPEN . . 990

\$4. Indelingskarakteristieken in rechtsvergelijkende systemen $\ldots \ldots \ldots \ldots 9$

A. DE RECHTSFAMILIE . . . . . . . . . . . . . . . . . 91

B. HET RECHTSSTELSEL . . . . . . . . . . . . . . . . . . . 95

C. HET RECHTSGEBIED . . . . . . . . . . . . . . 97

\$. Het systeem van de Library of Congress Classification . . . . . . . . . . . 99

A. HET INDIVIDUELE RECHTSSTELSEL ALS VERTREKPUNT . . . . . . . . 99

B. MODELCLASSIFICATIES . . . . . . . . . . . . . . . . . 10॥

C. Hiërarchische relaties $\ldots \ldots \ldots \ldots \ldots \ldots$

\section{Hoofdstuk V}

Rechtsvergelijkende thesauri . . . . . . . . . . . . . . . . . . . . 107

1. Begripsrepresentatie met een thesaurus . . . . . . . . . . . . . 107

A. RELATIES TUSSEN DESCRIPTOREN . . . . . . . . . . . . . . . 107

B. HiËrarchische relaties $\ldots \ldots \ldots \ldots \ldots \ldots \ldots \ldots \ldots$

$\S 2$. De geautomatiseerde thesaurus $\ldots \ldots \ldots \ldots \ldots \ldots \ldots \ldots \ldots$

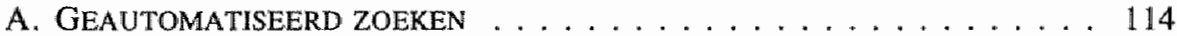

B. OPBRENGST EN PRECISIE $\ldots \ldots \ldots \ldots \ldots \ldots \ldots \ldots \ldots$

\$3. De juridische thesaurus . . . . . . . . . . . . . . . . 119

A. SElectie VAN RechtSTERMEN . . . . . . . . . . . . . . . . 119

B. POSTCOÖRDINATIE . . . . . . . . . . . . . . . . . . 122

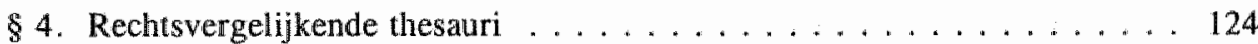

A. MeERTAlige thesauri . . . . . . . . . . . . . . . . . 124

B. De INdeX to Foreign Legal PERIOdicals . . . . . . . . . . . . . 129

C. RECHTSVERGELUKENDE THESAURI . . . . . . . . . . . . . 133 


\section{Hoofdstuk VI}

Rechtsvergelijkende begripskwalificatie in het $\mathrm{JPR} \ldots \ldots \ldots \ldots$

81. Het kwalificatieprobleem in het IPR . . . . . . . . . . 137

A. VERWIJZINGSREGELS IN HET IPR . . . . . . . . . . . 137

B. KWALIFICATIE MET EEN VERWIJZINGSCATEGORIE . . . . . . . . 141

82. Het yoorwerp van de begripskwalificatie . . . . . . . . . . 147

A. HET PREJURIDISCHE vOORWERP . . . . . . . . . . . 147

B. DE RECHTSVRAAG ALS VOORWERP $\ldots \ldots \ldots \ldots \ldots \ldots \ldots$

C. RECHTSREGELS ALS VOORWERP . . . . . . . . . . . . . 152

\$3. De grondslag van begripskwalificatie . . . . . . . . . . . 154

A. LEX FORI ALS UITGANGSPUNT . . . . . . . . . . . . . 154

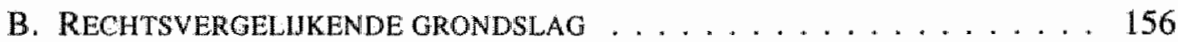

\$4. Verwijzingscategorie en materiële regels . . . . . . . . . . 160

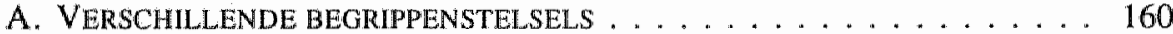

B. ONBEKENDE RECHTSINSTELLINGEN $\ldots \ldots \ldots \ldots \ldots \ldots \ldots$

\section{Hoofdstuk VII}

Conclusies . . . . . . . . . . . . . . . . . . . . . . . 165

$\S 1$. Direct nut van comparatieve begrippen . . . . . . . . . . 165

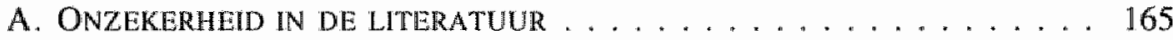

B. VOORWAARDEN VOOR DIRECT NUT . . . . . . . . . . . 167

82. Indirect nut van comparatieve begrippen . . . . . . . . . . . 169

A. RECHTSVERGELIJKENDE ORDENINGSSYSTEMEN . . . . . . . . . . 169

B. RECHTSVERGELIJKENDE THESAURI . . . . . . . . . . . . 171

C. RECHTSVERGELIJKENDE BEGRIPSKWALIFICATIE IN HET IPR $\ldots \ldots \ldots 172$

\$3. Mogelijke studies omtrent comparatieve begrippen . . . . . . . . 175 


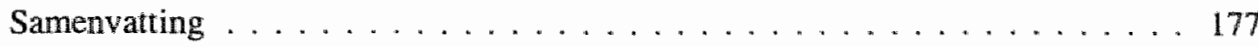

\section{Summary}

The Applicability of Comparative Concepts $\ldots \ldots \ldots \ldots \ldots . \ldots 181$

Glossarium en register $\ldots \ldots \ldots \ldots \ldots \ldots \ldots \ldots$

Geciteerde literatuur . . . . . . . . . . . . . . . . . . . . . . . 197

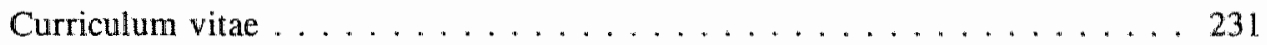




\section{Inleiding}

Rechtsbegrippen zijn veelal nationale rechtsbegrippen. Dit kan worden toegelicht met het voorbeeld van 'adioptie'. In de rechtsvergelijkende literatuur' wordt een onderscheid gemaakt tussen adoptie met een sterke werking en adoptie met een zwakke werking. Adoptie met een sterke werking, 'sterke adoptie' genoemd, heeft andere rechtsgevolgen dan adoptie met een zwakke werking, 'zwakke adoptie' genoemd. Het verschil in rechtsgevolgen betreft de band van het kind met de oorspronkelijke ouders. Sterke adoptie vervangt de oorspronkelijke band volledig, zwakke adoptie niet. In Engeland kent men uitsluitend de sterke adoptie ${ }^{2}$ zodat de rechtsterm 'adoption' daar betrekking heeft op rechtsregels met de rechtsgevolgen van de sterke adoptie. Het Engelse rechtsbegrip dat wordt weergegeven met "adoption", is geen universeel rechtsbegrip omdat er rechtsstelsels zijn met een zwakke adoptie, bijvoorbeeld dat van Oostenrijk $^{3}$. Rechtsstelsels ${ }^{4}$ bevatten verschillende rechtsbegrippen; deze rechtsbegrippen worden weergegeven met rechtstermen die verwijzen naar rechtsregels met uiteenlopende rechtsgevolgen.

1. Krause, 86-91, Schmidt, 2. In de lijst met geciteerde literatuur zijn de bibliografische gegevens opgenomen van de publicatie waarnaar wordt verwezen. Als er meer publicaties van dexelfde auteur geciteerd worden, wordt een jaartal toegewoegd aan do auteursnaam; zonodig met een letter erbij om publicaties van hetzelfde jaar te onderscheiden.

2. Krause, 87, 90-91.

3. Krause, 90 .

4. Ook al beweert Butler 1992, 699-701, dat het internationale publiekrecht als een afzonderlijk rechtsstelsel kan worden gezien, toch is de vergelijking tussen het wolkenrecht en nationale rechtsstelsels veelal van andere aard dan de vergelijking tussen nationale rechtsstelseis onderling. Hierna zal 'rechtsvergelijking' dan ook worden beperkt tot de vergelijking tussen nationale rechtsstelsels, met uitzondering van het internationale publiekrecht. 
Rechtstermen hebben een betekenis die is verbonden met een of ander rechtsstelsel. De Engelse rechtsterm 'adoption' kan niet zonder meer worden gebruikt voor het beschrijven van het thema van een rechtsvergelijker die zowel de Engelse als de Oostenrijkse adoptie onderzoekt. De mededeelbaarheid van het thema van rechtsvergelijkend onderzoek is gebrekkig. De Engelstalige term 'adoption' maakt niet onmiddellijk duidelijk dat het onderzoek zich uitstrekt naar rechtsstelsels met een zwakke adoptie. Een internationale rechtstaal of rechtsterminologie die eenduidig wordt verstaan door een mondiaal gehoor, ontbreekt wrijwel geheel ${ }^{5}$. Er bestaat geen juridisch Esperanto ${ }^{6}$.

De rechtsvergelijker moet taalbarrières overwinnen voordat hij toekomt aan het vergelijken van rechtsregels van verschillende landen. Omdat een internationale rechtsterminologie ontbreekt, moet de onderzoeker de rechtsbegrippen van een ander land identificeren. Het is de vraag of hij daarin volledig kan slagen want elke rechtsvergelijker is vooral vertrouwd met de begrippen van zijn eigen rechtsstelsel ${ }^{7}$. Het is echter niet noodzakelijk dat hij daarvan volledig afstand neemt ${ }^{8}$. Hij kan zijn nationale begrippen als uitgangspunt ${ }^{9}$ nemen en expliciteren in het vergelijkingsproces. Het vaststellen van de yergelijkbaarheid van de regels van bijvoorbeeld het Nederlandse appartementsrecht en het Duitse Wohnungseigentum is mogelijk vanuit de Nederlandse definitie ${ }^{10}$ die met de Duitse definitie ${ }^{\text {II }}$ geconfronteerd wordt. Dan blijkt het Nederlandse kenmerk "gebruiksrecht" ongeschikt in tegenstelling tot het comparatieve begrip "mede-eigendom".

5. Er bestadt een internationale vaktaall of terminologie voor het volkenrecht en het recht van de Europese Gemeenschap: De Groot 1990a, 21; De Groot 1990b, 122. In deze rechtsgebieden is een 'supranationalle" rechtstaal mogelijk als gevolg van overdracht van staatssoevereiniteit. Zo bezitten de termen in een meertslig verdrag ontanks de verschillende taalversies dezelfde betekenis in elke authentieke tekst: of. Butter 1985,65 ; cf. Jennings/Watts, 1283 . Overigens is de terminologie wan het internationale publiekrecht vectal ontleend an én of meer nationale rechtstalen: of. Butler $1985,58$.

6. Cf. Constantinesco 1974, 314.

7. Cr. Esser, 341, 346; cf. Rabel 1958, 65; cf. Rigaux 1956, 155; cf. Sauveplanme 1975a, 36-37.

8. Sauveplatne 1975a, 28; cf. Gadamer, 374-375: 'Die eigenen Begriffe bei der Auslegung vermeiden zu wollen, is nicht nur unmöglich, sonderi offenbarer Widersinm. Auslegen heiBt gerade: die eigenen Vorbegriffe mit ins Spiel bringen, ${ }_{\text {.... }}$.

9. Cf. Kant, 153a-154a: (A 106) 'Alles Erkenntnis erfordert einen Begriff, dieser mag nun so unvollkommen, oder so dunkel sein, wie er wolle:..."

10. Art. 106 lid 3 boek 5 BW: "Onder appartementsrecht wordt werstan een aandeel in de goederen die in de splitsing zijn betrokken, dat de bevoegdheid omwat tot het uitsluitend gebruik van bepaalde gedeelten van het gebouw die blijkens hun inrichting bestemd zijn of worden om als afzonderlijk geheel te worden gebnilikt"

11. Par. 1 Gesetz uber das Wohnungseigentum und das Dauerwohnrecht: "Wohnungseigentum ist das Sondereigentum an einer Wohnung in Verbindung nit dem Miteigentumsanteil an dem gemeinschaftlichen Eigentum, zu dem es gehört'. 
De onderzoeker moet een 'comparatief begrip' vormen; dit is een begrip dat in de rechtswergelijking ${ }^{12}$ gehanteerd wordt.

In de literatuur zijn voorbeelden van afzonderlijke comparatieve begrippen genoemd, zoals 'rule of law' ${ }^{13}$ en 'ongerechtvaardigde verrijking" "Een alomvattend stelsel waarmee alle rechtsregels van alie rechtsstelsels vergelijkbaar zouden worden, is niet gerealiseerd; dit is een desideratum. Een alomvattend comparatief begrippenapparaat moet misschien een utopie blijven. Dit neemt niet weg dat een minder omvattend begrippenstelsel bruikbaar is woor het rechtsvergelijkend onderzoek, ook all strekt dit stelsel zich niet uit tot complete rechtsstelsels. Dit leidt tot de vraag of het realiseren van een bescheiden comparatief begrippenapparaat kans van slagen heeft. Köt $\mathrm{Z}$ is optimistisch: hij is acht de constructie van een Europese lingua franca met ruime rechtsbegrippen eenvoudig. Deze mening wordt door anderen bestreden omdat het ontwikkelen van een stelsel van comparatieve begrippen de inspanning van een groot aantal rechtsvergelijkers gedurende een lange periode zou kunnen vergen ${ }^{16}$. Ook gezien de kosten $^{17}$ die hiermee gemoeid zouden zijn, moet het nut van comparatieve begrippen aannemelijk worden gemaakt.

Het bepalen van het nut van comparatieve begrippen is het doel van dit proefschrift, niet het bepalen van het nut van rechtsvergelijkend onderzoek. Comparatieve begrippen zijn bruikbaar voor het rechtsvergelijkend onderzoek als ze een basis verschaffen voor het

12. Binnen één rechtsstelsel lkan sprake zjijn van 'inteme techtswergelijking': de vergelijking tussen rechtisgebieden binnen dezelfde nationale rechtsorde: Van Schendel, 2. Interne reehtsvergelijking bijft hienha buiten beschouwing. Vergetijkende rechtsgeschiedenis blijft hiernat eveneens buiten beschouwing. Rechtsvergelijking wordt hier opgevat als de discipline die is gericht op hedendagge rechtsstelsels waarin de rechtstaal te onderscheiden is van de omgangstabl.

13. Kokkini 1985, 11-12; Kokkini 1988a, 92; Rozmaryn 1958, 72.

14. Esser, 357; Zweigert 1960, 199; Zweigert/Kötz 1996, 44.

15. Kötz 1992, 41 .

16. Cf. De Groot 1987, 24; cf. De Boer 1992, 45.

17. Een enigszins nawwkeurige benadering is net te geven. Een globale indicatie van de kosten die zijn gemoeid met organisatie en productie kan wellicht worden gevonden bij Drobnig 1972, 128, die destijds een totaalbedrag van drie miljoen Amerilkaanse dollars noemde voor de "International Encyclopedia of Comparative Law'. Daarbij kan worden werondersteld dat de baten in de vorm van tijdbesparing voor rechtsvergeljikende onderzoekers een veelvoud zullen zijn van de kosten. Een vorzichtige schatting leert immers dat ruim de helft van de werktijd van een rechtsvergelijkende onderzoeker wordt besteed aan het zoeken van informatie: of. Gödan 1986, 4 . 
vergelijken wan rechtsregels van verschillende rechtsstelsels ${ }^{18}$. Zij hebben dan direct nut binnen de rechtsvergelijking als theoretische discipline. Het is niet noodzakelijk dat rechtsvergelijking dienstbaar wordt gemaakt aan het wetgevingsproces: kennisvermeerdering is wellicht ${ }^{19}$ ook een legitieme doelstelling. Het directe nut van comparatieve begrippen is onafhankelijk van het nut van rechtsvergelijking. Het nut van rechtsvergelijkend onderzoek wordt op zijn beurt bepaald door de toepassing van de resultaten van dat onderzoek. De verworven kennis kan bijvoorbeeld gebruikt worden voor de oplossing van problemen van het eigen rechtsstelsel ${ }^{20}$. Het beoogde gebruik van rechtsvergelijking is van belang voor het onderzoeksthema ${ }^{21}$ waarvoor comparatieve begrippen gevormd wordlen. Het onderzoeksdoel kan echter geen basis verschaffen voor de vergelijkbaarheid van rechtsregels ${ }^{22}$. Niet elk onderzoeksthema is geschikt voor het beoogde gebruik van rechtsvergelijking. Het thema 'ongerechtvaardigde verrijking' is onbruikbaar voor het verbeteren van de nationale adoptiewetgeving. Als dit onderzoeksdoel niet voor ogen wordt gesteld, kan het comparatieve begrip 'ongerechtvaardigde verrijking' direct nut hebben.

De wenselijkheid van specifiek gebruik van rechtsvergelijking blijft hierna buiten beschouwing. Noch verbetering van wetgeving ${ }^{23}$ noch kennisvermeerdering zijn doelstel-

18. Rechtsvergelijking kan zich uitstrekken tot een hele rechtscultuur. Daaronder kan met Friedman, 76 , het wolgende verstaan worden: "attitudes, values, and opinions held in society, with regard to law, the legal system, and its various parts." Cf. Friedman, 7. Culturele aspecten blijwen in deze srudie buiten beschouwing.

19. Cf. De Boer 1994, 306 .

20. Cf. De Boer 1992, 40, 42, 46; cf. De Boer 1994, 306 .

21. Cf. Florijn, 144, 146.

22. Sclumidi, 12, 16, 19, suggereert het tegendeel.

23. Zowel Sandrock als Rozmanyn laten zich uit over het indirecte nut van comparatieve begrippen voor de toepassing op en rechtsstelsel. Sandrock 58 , beweert dat bovernationale begrippen, die uitsluitend de wezenlijke eigenschappen van nationale rechtsregels bevatten, slechts een zeer beperkte heuristische warde toekomt: met behulp van deze compratieve begrippen kan wonden aangetoond welke eigenschappen van een national rechtsbegrip essentieel zijn in het licht van andere rechtsstelsels. Dit kan vervolgens een nieuw en ruimer perspectief opleveren bij de watardering van afzonderlijke elementen van egn mational begrip. De heuristische waarde van bovennationale begrippen is volgens Sandrock, 59,61 , niettemin beperkt ondat de vorming en precisering van begrippen van én stat slechts in uitzonderlijke gevallen op een rechtsvergelijkende wijze kan geschieden omdat deze begrippen meestal overwegend bepaald zijn door het nationale rechtssysteem. Rozmaryn meent op zijn beurt dat comparatieve begrippen nut voor het eigen rechtsstelsel zouden kunnen hebben. Volgens Rozmaryn 1958, 71 72,75 , is een comparatief begrip zoals de "rule of law" een resultaat van rechtswergelijkend onderzoek dat heuristisch nut bezit want dit resultaat vestigt de aandacht op de rechtsinstellingen waarmee het eigen rechtssysteem verbeterd kan worden. Het gaat beide auteurs om het gebruik van rechtsvergellijking voor do verbetering van weigeving. De doelstelling van comparatieve begrippen die Sandrock en Rozmarym hier formuleren, bliff verder buiten beschouwing. 
lingen van comparatieve begrippen. Het nut van comparatieve begrippen wordt primair bepaald door het rechtsvergelijkend onderzoek warin ze worden toegepast. Comparatieve begrippen die binnen het onderzoek onbruikbaar zijn, zijn a fortiori onbruikbaar buiten het onderzoek.

Er is verondersteld dat comparatieve begrippen onderzoeksresultaten zijn met indirect nut buiten de rechtsvergelijking. In deze gebieden zou niet alleen sprake zijn van rechtsvergelijking, maar ook van toepassing van comparatieve begrippen. $Z 0$ is de vertaling van juridische teksten wellicht een toepassingsgebied van comparatieve begrippen, maar deze problematiek gaat het bestek van dit proefschrift te buiten. De volgende toepassingsgebieden zullen in afzonderlijke hoofdstukken geanalyseerd worden: rechtsvergelijkende ordeningssystemen voor bibliotheekcollecties, rechtsvergelijkende thesauri en de begripskwalificatie in het internationaal privaatrecht (IPR). Hierin zijn overeenkomsten en verschillen tussen rechtsstelsels aan de orde. De eventuele bruikbaarheid van comparatieve begrippen voor deze toepassingsgebieden moet nader onderzocht worden omdat hierin nog een reden gevonden kan worden om een stelsel van comparatieve begrippen te ontwikkelen.

Het doel van het toepassingsgebied is uiteindelijk bepalend voor het nut van comparatieve begrippen voor dat toepassingsgebied. Het doel van rechtsvergelijkende ordeningssystemen en thesauri is het terugvinden van documenten omtrent een buitenlands rechtsbegrip met een nationaal rechtsbegrip. Voor dat doel bevatten ordeningssystemen rechtsvergelijkende classificatiebegrippen, bijvoorbeeld een classificatiebegrip dat staat voor 'adoptie'. Hierbij staan de termen 'zwakke adoptie' en 'sterke adoptie' vermeld zodat met 'sterke adoptie' ook documenten omtrent 'zwakke adoptie' gevonden kunnen worden; deze documenten zijn bij hetzelfde classificatiebegrip "adoptie' ingedeeld.

Voor het terugvinden van documenten omtrent een buitenlands rechtsbegrip met een nationaal rechtsbegrip bevatten rechtsvergelijkende thesauri relaties van termen, bijvoorbeeld: 'zwakke adoptie' USE 'adoptie' en 'sterke adoptie' USE 'adoptie'. Omdat "adoptie' wordt toegekend aan de betreffende documenten, kunnen met 'sterke adoptie' ook documenten omtrent 'zwakke adoptie' gevonden worden. Voor de keuze van classificatiebegrippen of thesaurustermen kunnen comparatieve begrippen worden gebruikt. Met het comparatieve begrip 'adoptie' kunnen documenten omtrent corresponderende rechtsbegrippen van andere rechtsstelsels worden gevonden. Daarmee is het nut van comparatieve begrippen voor rechtsvergelijkende ordeningssystemen en thesauri nog niet aangetoond. 
Behalve rechtsvergelijkende ordeningssystemen en thesauri is er nog een derde toepassingsgebied van comparatieve begrippen. De begripskwalificatie is een probleem van het IPR. Wanneer de rechter in privaatrechtelijke kwesties met een grensoverschrijdende dimensie moet kiezen tussen rechtsregels van verschillende rechtsstelsels, wordt deze keuze geleid door verwijzingsregels. Een verwijzingsregel bevat een verwijzingscategorie die ook buitenlandse rechtsregels omvat. Met de verwijzingscategorie kunnen buitenlandse rechtsregels worden gekwalificeerd omdat de verwijzingscategorie in mindere mate is gebonden aan het eigen rechtsstelsel dan de overige nationale rechtsbegrippen. De keuze tussen verwijzingscategorieën is echter problematisch omdat zij ruim geformuleerd zijn: als een verbroken verloving gekwalificeerd moet worden, komen zowel 'familierecht' als 'onrechtmatige daad' in aanmerking ${ }^{24}$. Voor de oplossing van dit kwalificatieprobleem moet de verwijzingscategorie gepreciseerd worden met nationale en buitenlandse rechtsbegrippen. Als deze rechtsbegrippen gerelateerd kunnen worden met een comparatief begrip dat precies genoeg is om de toepasselijke verwijzingsregel te kiezen, heeft dit comparatieve begrip nut voor de begripskwalificatie in het IPR.

In dit proefschrift wordt de literatuur (hoofdstuk II) omtrent de verschillende vormen van comparatieve begrippen weergegeven voordat een kritische bespreking uitmondt in een eigen standpunt (hoofdstuk III). Het eigen standpunt betreft de vorming van een comparatief begrip dat nuttig is voor het rechtsvergelijkend onderzoek. Het eigen standpunt gaat vooraf aan de analyse van de toepassingsgebieden (hoofdstukken IV, V en VI) omdat de toepassingsgebieden aan hun doel kunnen beantwoorden zonder het gebruik van comparatieve begrippen. Deze studie wordt afgesloten met een aantal conclusies (hoofdstuk VII) ten aanzien van de eventuele bruikbaarheid van comparatieve begrippen voor het rechtsvergelijkend onderzoek en de drie toepassingsgebieden.

24. Rb Rotterdam 27-7-1932, Nederlandse Jurisprudentie 1933, p. 311-312; cf. Cohen Henriquez 1980. $46-47$. 


\section{De problematiek van de comparatieve begrippen}

\section{$\S 1$. Soortbegrippen en typebegrippen}

Dit hoofdstuk biedt een overzicht van de problematiek van de comparatieve begrippen in de rechtsvergelijkende literatuur. Eerst wordt ingegaan op het nut dat comparatieve begrippen zou toekomen. Vervolgens wordt de wijze van totstandkomen van comparatieve begrippen behandeld. Daarna komt aan de orde hoe comparatieve begrippen weergegeven kunnen worden in termen. Aan het einde van dit hoofdstuk wordt aangegeven hoe de problematiek van de comparatieve begrippen zal worden behandeld in de volgende hoofdstukken. Dit hoofdstuk begint met een aantal opmerkingen als kader voor de problematiek van de comparatieve begrippen.

In de rechtsvergelijkende literatuur omtrent comparatieve begrippen is het onderscheid tussen soortbegrippen en typebegrippen onderbelicht. Om dit onderscheid te illustreren zal hierna het voorbeeld van het 'appartementsrecht' worden gebruikt.

Stel dat de volgende objecten zijn gegeven: het Zwitserse, het Franse en het Duitse appartementsrecht. Deze objecten hebben verschillende eigenschappen en zijn voorzien van verschillende termen. De $Z$ witserse gemeenschap van appartementseigenaren is ten bijzondere vorm van mede-eigendom die 'Miteigentümergemeinschaft' of 'copropriété adaptée' wordt genoemd. In Frankrijk is de mede-eigendom van de gemeenschappelijke gedeelten afhankelijk van de volle eigendom van de privégedeelten; hier wordt het appartementsrecht 'copropriété des immeubles bâtis' genoemd. Voor het Duitse 'Woh" nungseigentum' geldt daarentegen dat de volle eigendom van de privégedeelten van 
woningen afhankelijk is van de mede-eigendom van de gemeenschappelijke gedeelten ${ }^{25}$. De rechtsvergelijker kan dit thema aanwijzen door het opsommen van de termen 'Miteigentümergemeinschaft', "copropriété des immeubles bâtis' en 'Wohnungseigentum". Vervolgens heeft hij een term nodig om over deze objecten te kunnen spreken. Daartoe kan de Engelstalige term "appartment ownership" ${ }^{26}$ worden gekozen. Met het comparatieve begrip 'appartment ownership' kan worden gesproken over 'Miteigentümergemeinschaft", "copropriété des immeubles bâtis" en 'Wohnungseigentum', termen uit de rechtstaal van Zwitserland, Frankrijk en Duitsland. Daarmee behoort 'appartment ownership' tot een 'metataal': een taal die geschikt is om uitspraken te doen over de objecttalen ${ }^{27}$ met de drie termen.

Oordelen met comparatieve begrippen behoren niet tot het niveau van een objecttaal maar tot een metataal. Oordelen die comparatieve begrippen bevatten, worden hiema "vergelijkbaarheidsoordelen" genoemd. Een vergelijkbaarheidsoordeel ${ }^{28}$ is een hypothese die getoetst moet kunnen worden aan verschillende rechtssielsels in de werkelijkheid. Een voorbeeld van een vergelijkbaarheidsoordeel is het volgende: de regels omtrent het appartementsrecht in het Nederlandse rechtsstelsel zijn vergelijkbaar met de regels omtrent het Duitse Wohnungseigentum vanwege de overeenkomst "mede-eigendom'29.

Een comparatief begrip moet expliciet gemaakt worden om een vergelijkbaarheidsoordeel te kunnen bevestigen of weerleggen. Dit impliceert dat duidelijk moet zijn welke "intensie' ${ }^{30}$ het comparatieve begrip bezit. Deze intensie bestaat uit één of meer kenmerken ${ }^{31}$. De intensie valt samen met de betekenis van een term ${ }^{32}$. De intensie van het comparatieve begrip 'appartment ownership' bestaat bijwoorbeeld uit de volgende kenmerken: individuele eigendom van een appartement; gemeenschappelijke eigendom

25. Mertens, 330-331; Van der Merwe, 20, 24-25.

26. Van der Merwe, 20.

27. Klug, 104 .

28. Niet verwarren met het oordeell 'dit is groter dan dat' dat een comparatieve eigenschap betreft: of. Herberger/Simon, 279: het ene object komt de eigenschap 'grootte' meer toe dan het andere object. Cf. Kuhlen 1976, 61: Kuhten 1977, 35; Speck, 63; Tsouyopoulos, 152; Wank, 36. Het voorstel van Hedenius (zoals weergegeven door Frändberg, 89-90) om "ideaaltypen" te construeren, heidt ertoe dat 'eigendom' als een comparatieve eigenschap wordt opgevat. Ook het comparatieve rechtsbegrip van Rottenthuer, 165-169. betreft comparatieve eigenschappen wan rechtsnomen. Comparatieve eigenschappen zijn hier niet aan de orde.

29. Zie hoofdstuk I.

30. De alternatieve term 'begripsinhoud' is niet meer gebruikelijk: Herberger/Simon, 248.

31. Loth 1991,78 ; cr. Sartori, 24,78 .

32. Loth $1986,233$. 
van de grond en het gebouw; lidmaatschap van een vereniging van appartementseigenaren $^{33}$. Deze kenmerken zijn de voorwaarden voor de juiste toepassing van het comparatieve begrip "appartment ownership" op een object met de vereiste eigenschappen ${ }^{34}$ Deze drie kenmerken zijn verbonden ("conjunct') in een "conjunct soortbegrip". Als de objecten 'Miteigentümergemeinschaft', 'copropriété des immeubles bâtis' en 'Wohmungs eigentum" slechts aan één of twee criteria van de intensie van "appartment ownership" voldoen, is dat comparatieve soortbegrip daarop niet van toepassing 35 . Dan behoren deze regels niet tot de "extensie" "36. de verzameling van objecten wararan een begrip toekomi $^{37}$. Deze regels zijn niet vergelijkbaar in het opzicht ${ }^{38}$ van het gekozen soortbegrip.

Als men het $\mathcal{Z}$ witserse appartementsrecht met andere rechtsstelsels wil vergelijken; is het wellicht ondoelmatig om een comparatief begrip in de vorm van een conjunct soortbegrip te gieten. Het alternatief is een "disjunct typebegrip" ${ }^{39}$. Dan behoeven de objecten niet aan alle kenmerken te beantwoorden omdat deze kenmerken in een disjunctieve verhouding staan ${ }^{*}$. Bij de toepassing van een typebegrip kan buiten beschouwing blijven dat aan een kenmerk niet wordt voldaan ${ }^{41}$. Tot de extensie van een typebegrip behoren objecten die niet allemaal voorzien zijn van gemeenschappelijke eigenschappen. Het is toegestaan dat een object niet alle eigenschappen theeft ${ }^{42}$. Tot de extensie van een typebegrip behoren objecten die gelijkenissen vertonen want niet alle objecten beantwoorden aan alle kenmerken ${ }^{43}$. Als het comparatieve begrip "appartment owner-

33. Vain der Merwe, 23, 27.

34. Cf. Herberger/Simon, 209, 291; of. Kuhlen 1977, 28-29.

35. Cf. Kuhlen 1976, 56; of. Loth 1991, 94; cf. Tsouyopoulos; 152.

36. De alternatieve term "begripsomyang" is niet meer gebruikelijk: Herberger/Simon, 248.

37. Franken, 69; cf. Norrektit, 92.

38. Cf. Norreklit, 192: Exery comparison presupposes a respect in which we compare.

39. In de literatuur omtrent comparatieve begrippen worden een aantal uitd rukkngengebezigd die wellicht duiden op een rypebegrip Constantinesco 1974,317 , werwijst nar de supranationale typen van Sandrock, 58, 65. Op zijh beurn werwerpt. Rozmaryn 1958, 70-71 "ideatitypen' of 'modelten'; cf. Kokkini 1985, 11: "ideaal-modellen". Het is voorts niet uit te sluiten dat er typebegrippen vergelijkend gehanteerd zijn in het onderzoek van Jowchim. In het Amerikaanse handelsrecht is sprake vian de 'reasonable man' en in thet Duitse Hande!srecht wan de "verständige Rechtsgenosse": cf. Joachin, 359. De 'verständige Rechtsgenosse' komt voor in de Duitse jurisprudentie, niet in het Handelsgesetabuch: Joachim, 351; fo. Joachim, 355-356. Deze begrippen kunmen warden beschouwd als een uitvloeisel van de traditie van de "prudentia", de deugd die de meins in staat stelt passend te handelen in verschillende situaties: cf. Esser, 96; cf. Van Laer 1978, 256-257.

40. Franken, 82: 'of/of' in plaats van "en/en".

41. Kuhlen $1977,120$.

42. Loth $1991,95$.

43. Kuhten 1977, 132; Loth 1991, 94, 100. 
ship' als een disjunct typebegrip wordt gehanteerd, kunnen objecten die niet aan alle criteria voldoen toch worden gerekend tot de objecten walarop dat comparatieve begrip van toepassing is. Mits dit typebegrip expliciet wordt geformuleerd, is het oordeel dat hier een vergelijkingsbasis aanwezig is, te bevestigen voor een ruimer onderzoeksthema dan in het geval van een soortbegrip. De keuze van de intensie van een comparatief begrip is een kwestie van doelmatigheid. Wanneer deze intensie opgenomen wordt in het oordeel dat rechtsregels van verschillende rechtsstelsels vergelijkbaar zijn, is dit oordeel te bevestigen of te weerleggen.

Soortbegrippen en typebegrippen zijn verschillende vormen waarin comparatieve begrippen gegoten kunnen worden. De vorm van het begrip mag niet verward ${ }^{44}$ worden met de eventuele vaagheid van een begrip. In het geval van vaagheid kan niet worden beslist tot toepassing van een begrip, bijvoorbeeld 'vaartuig', op het object: zeilplank ${ }^{45}$. Vaagheid kan gepaard gaan met soortbegrippen en met typebegrippen ${ }^{46}$. Het onderscheid tussen soortbegrippen en typebegrippen is van belang voor het vervolg van dit hoofdstuk waarin de literatuur omtrent comparatieve begrippen geanalyseerd wordt. Deze begripswormen keren terug in hoofdstuk III waarin een eigen standpunt wordt ontwikkeld ten aanzien van het nut van comparatieve begrippen.

\section{§ 2. Verondersteld nut van comparatieve begrippen}

\section{A. DiRect NuT}

Het centrale thema van deze studie is het nut van comparatieve begrippen. Daarom begint deze paragraaf met de behandeling van het nut dat comparatieve begrippen zouden hebben volgens de auteurs die daarover hebben geschreven. Eerst komt het directe nut van comparatieve begrippen aan de orde. Dat is aanwezig indien comparatieve begrippen de rechtswergelijkende onderzoeker leiden naar zijn voorwerp van onderzook: vergelijkbare rechtsregels. Van het directe nut van comparatieve begrippen is hun indirecte nut te onderscheiden. In het laatste geval gaat het om mogelijke toepassingen van comparatieve begrippen buiten de rechtsvergelijking in enge zin: bijvoorbeeld in het kader van het internationaal privaatrecht ${ }^{47}$. Wanneer comparatieve begrippen bijdragen aan het vinden van juridische documenten die relevant zijn voor rechtsvergelijkend onderzoek, is het indirecte nut van comparatieve begrippen eveneens aan de orde.

44. Kuhlen 1976, 63. Wellicht ten overvloede: een typebegrip is geen vaag begrip.

45. Kuhlen 1976, 53 noot $\llbracket$; Kuhlen 1977, 81-82; zie verder VI. 1 . B.

46. Loth 1991, 93 .

47. Cf. De Groot 1989,2 
Engisch veronderstelt dat comparatieve begrippen direct nut voor het rechtsvergelijkende onderzoek bezitten. Engisch ${ }^{48}$ poneert dat de rechtsvergelijkend onderzoeker universele ${ }^{49}$ begrippen nodig heeft die van bijzonderheden van de afzonderlijke rechtsstelsels abstraheren. Het is niet noodzakelijk dat universele rechtsbegrippen op alle rechtsstelsels van toepassing zijn. Als voorbeeld noemt hij het universele begrip wan de 'koop' dat ruimer ${ }^{s 0}$ moet zijn dan het begrip van de 'koop' volgens het Duitse burgerlijke recht. Volgens Engisch kunnen slechts met universele rechtsbegrippen relaties worden gelegd tussen de verschillende in aanmerking komende rechtsstelsels. Het directe nut van comparatieve begrippen is echter niet beperkt tot her vinden van relaties tussen rechtsstelsels. Volgens Engisch ${ }^{51}$ kan met een universeel rechtsbegrip in rechtsvergelijkend onderzoek worden vastgesteld dat een dergelijk rechtsbegrip thuishoort in rechtsstelsels van een bepaalde aard, daarentegen niet in rechtsstelsels die vreemd zijn aan een rechtsfamilie. In het laatste geval kan met het comparatieve begrip een uitwendige grens van een rechtsfamilie ontdekt worden. In het eerste geval kan een universeel rechtsbegrip binnen de grenzen van de rechtsstelsels die tot dezelfde rechtsfamilie behoren, worden gebruikt ter concretisering van overeenkomsten en verschillen, die zich voordoen in manifestaties van dat universele rechtsbegrip. In clat geval gat het volgens Engisch om een openheid voor differentiaties binnen de grenzen van een rechtsfamilie. Het directe nut van comparatieve begrippen manifesteert zich volgens Engisch niet alleen in het vinden van relaties tussen rechtsstelsels; maar ook in het ontdekken van grenzen tussen rechtsstelsels en van overeenkomsten en verschillen binnen een aantal rechtsstelsels. Men kan zeggen dat Engisch het nut van comparatieve begrippen ziet in een indeling van de werkelijkheid in een vergelijkbaar segment naast een onvergelijkbaar segment.

Kokkini ziet het nut van comparatieve begrippen in hun toepassing binnen het rechtsvergelijkend onderzoek. Volgens Kokkini ${ }^{52}$ moet een onderscheid worden gemaakt tussen het inleidende onderzoek enerzijds en het systematische rechtsvergelijkende onderzoek anderzijds. Het opsporen van de vergelijkbaarheid vormt het voorwerp van inleidend onderzoek ${ }^{53}$. Het inleidende onderzoek is geen onderdeel van het systematische onderzoek $^{54}$. De vaststelling van gelijkenissen en verschillen geschiedt in het stadium van systematische vergelijking ${ }^{55}$. Het systematische onderzoek kan de aanwezigheid van

48. Engisch 1958, 63-64. Hij baseert zich hier op Eltzbacher: zie verder 11 . \$ 3.A.

49. Deze universele begrippen zijn volgens Engisch 1958, 64, "empirisch allumfissend" en niet a priori.

50. Engisch 1958, 64, doet het Yoorstel om 'Austausch von Ware und Geld' tee introduceren.

51. Engisch 1958, 73: 'doppelte Relatiwitat'.

52. Kokkini $1988 \mathrm{~b}, 235-236$, in het kader van het tertium comparationis.

53. Cf. Kokkini 1988a, 131: "prealabel" onderzoek.

54. Kokkini 1988b, 235.

55. Kokkini 1988a, 145 . 
gemeenschappelijke elementen, die in het inleidende onderzoek zijn ontdekt, bevestigen $^{56}$. Volgens Kokkini is het nut wan comparatieve begrippen vooral gelegen in hun toepassing in het inleidende onderzoek. Bij het vinden van een vergelijkingsbasis is het probleem dat de gemeenschappelijke elementen zijn uitgedrukt in diverse termen en begrippen. Daarom dient het inleidende onderzoek grondig te zijn omdat de uiteindelijke keuze van het thema van vergelijking daarvan afhangt. In de systematische fase van thet onderzaek kan een verkeerde keuze van de vergelijkingsbasis niet meer ongedaan gemaakt worden zodat het inleidende onderzoek tijdverspilling nadien kan voorkomen ${ }^{57}$. Naar de overtuiging van Kokkini ${ }^{58}$ heeft een rechtsvergelijkend begrippenapparaat zowel praktische als methodologische betekenis; het zal een heuristische waarde voor het vergelijkende onderzoek hebben door behulpzaam te zijn bij het formuleren van juiste werkhypotheses en vraagstellingen. Foutieve redeneringen door terminologische voetangels zouden erdoor vermeden kunnen worden. Bovendien zou daarmee kunnen worden voldaan aan het fundamentele methodologische vereiste 'te vergelijken wat vergelijkbaar is':

Kokkini legt de nadruk op de eerste fase van rechtsvergelijkend onderzoek, Constantinesco op de laatste fase. Constantinesco ${ }^{59}$ beweert dat comparatieve begrippen geen uitgangspunt zijn van de toepassing van de vergelijkende methode; zij kunnen pas een rol spelen in de eindfase van het onderzoek, waarin de eigenlijke vergelijking plaatsvindt $^{60}$. Vergelijkbaarheid is een objectief gegeven dat voorafgaat aan de vergelijking; de onderzoeker moet de zekerheid hebben dat dit gegeven bestaat ${ }^{61}$, bijvoorbeeld uit onderzoeksresultaten van hemzelf of van anderen. Vergelijkbaarheid is geenszins afhankelijk van de resultaten van de vergelijking; de vergelijkbaarheid wordt geverifieerd en gepreciseerd door de daarop volgende vergelijking ${ }^{62}$. Constantinesco ${ }^{63}$ meent dat de rechtsvergelijkende methode volstaat voor een objectieve keuze en vergelijking van de objecten die in het onderzoek worden betrokken. Volgens Constantinesco is het mogelijk om rechtsstelsels direct te vergelijken zonder zijn toevlucht te nemen tot een

56. Kokkini 1988b, 235; ce. Kokkini 1988a, 132

57. Cr. Kokkini 1988b, 235-236.

58. Kokkini 1985, 9; Kokkini 1988a, 78 .

59. Constantinesco 1974,318 en noot 152 : in deze noot stent Constantinesco in met het standpunt wan Rozmatyn; of. Constantinesco 1983, 419.

60. Constantinesco $1974,123$.

61. Constantinesco 1974,79 en noot 91; cf. Van Reenen 1995, 180. Vergelijkbaarheid is volgens Constantinesco een eigenschap van de te vergelijken objecten: Constantinesco 1974, 79; cf. Van $\mathbb{R}$;eenen 1995, 179. Zo ook: Kokkini 1988b, 241.

62. Constantinesco 1974, 88; cf. Constantinesco 1974, 22, 24, 78 .

63. Constantinesco 1974,24 . 
tertium comparationis, een comparatief begrip. Volgens hem ${ }^{\text {th }}$ ontbreekt deze tevoren vastgestelde, objectieve en uitwendige maatstaf. Constantinesco ${ }^{65}$ beweert dat een comparatief begrip onpartijdig onderzoek verhindert. Hij ${ }^{\text {th }}$ meent dat comparatieve begrippen geen initiële vergelijkingsbasis opleveren; het zijn onderzoeksresultaten die de vergelijkbaarheid bevestigen.

Comparatieve begrippen kunnen niet alleen direct nut hebben voor begin- of eindfase van het rechtsvergelijkend onderzoek, maar ook voor het samenstellen van een classificatiesysteem dat resultaten van rechtsvergelijkend onderzoek geordend presenteert ${ }^{67}$, bijvoorbeeld in leerboeken of encyclopedieẽn. De mogelijkheid van dit laatste nut wordt onderkend in de rechtsvergelijkende literatuur. Daarin kunnen drie verschillende standpunten worden onderscheiden ten aanzien van bedoeld classificatiesysteem ${ }^{68}$ :

1) een absoluut-autonoom classificatiesysteem. Dit is een desideratum van Zweigert/Kötz ${ }^{69}$ die een bevrijding van de nationale systematiek verlangen voor de vorming van een eigen systematiek met universele, ruime functiebegrippen;

2) een relatief-autonoom classificatiesysteem. Dit wordt uitgewerkt door Drobnig;

3) een niet-autonoom classificatiesysteem; het standpunt van Constantinesco.

Ad 1) Het classificatiesysteem van Zweigert/Kötz is een uitvloeisel van hun functionele benadering die verderop in dit hoofdstuk ${ }^{70}$ wordt toegelicht. Daarop vooruitlopend kan worden geconstateerd dat dit classificatiesysteem niet wordt bepaald door de indeling van nationale rechtssystemen, maar door sociale problemen waarvoor functiebegrippen worden gevormd. Overigens komt het absoluut-autonome classificatiesysteem inductief tot stand, door voortdurend te experimenteren en te vergelijken ${ }^{71}$.

64. Constantinesco 1974, 36-37; cf. Van Reenen 1995, 177-178.

65. Constantinesco 1974,23 .

66. Constantinesco 1974, 78: ex is een tegensprask nussen de stelling dat het tertiun comparationis teen noodzakelijke voorwalude is voor vergelijking, en de stelling dat het tertium comparationis onderzoeksresultaat is.

67. Cf. Constantinesco 1974, 312-313; cf. Pawlowski, 84, 100, 238.

68. Het gaat hier niet on een programmatisch systeem zoals her 'Weltrechtssystem" van Coing. Coing. 28. staat een 'Welitrechtssystem' voor ogen dat onafhankelijk is wan wationale codificaties en dat ruimte biedt aan de privaatrechtelijke rechtsstelsels van de hele beschaafde wereld. Dit ' Weltrechtssystem' zow gefundeerd moeten zijn op de resultaten van rechtsvergelijkend en historisch onderzoek dat de algemene en principièle problematiek van de door het privatrecht te regelen 'Lebensbeziehungen' an de gezichtspunten voor de oplossing ervan, zou moeten uitwerken.

69. Zweigert/Kotz 1996, 43-44; cf. Zweigert 1960, 199; cf. Zweigert 1969 448; cf. Zweigert 1973.757.

70. Zie II. 3.C.

71. Zweigert/Kötz 1996, 45 
Ad 2) Drobnig 72 zoekt naar een systematiek die boven de nationale rechtssystemen staat om de resultaten van breed georiënteerd rechtsvergelijkend onderzoek te presenteren. Naar de mening van Drobnig ${ }^{73}$ mogen de bijzonderheden van bedoelde bovennationale systematiek niet a priori worden vastgelegd: ze moeten het resultaat van vergelijkend onderzoek ${ }^{74}$ zijn waarbij aansluiting moet worden gezocht bij éen of meer nationale classificatiesystemen en classificatiebegrippen. De nationale classificatiebegrippen kunnen echter niet zonder meer worden overgenomen in wat Drobnig ${ }^{75}$ een 'vergelijkend-autonome systematiek' noemt: deze bovennationale systematiek heeft eigen systeembegrippen nodig. Bij de ontwikkeling van een wergelijkend-autonome systematiek kan volgens Drobnig ${ }^{76}$ blijken dat de aansluiting bij nationale classificatiesystemen problematisch is; omdat deze voor een rechtsgebied niet overeenstemmen zodat een keuze moet worden gemaakt tussen de elkaar uitsluitende systemen. In dit verband haalt hij het voorbeeld van de trust aan: in het geval van deze rechtsinstelling sluiten de Anglo-Amerikaanse systematiek en de continentale indeling elkaar uit. Terwijl fundamentele begrippen zoals 'eigendom' universeel bekend zijn, beweerde Drobnig ${ }^{77}$ destijds dat de trust onbekend is buiten de common law-rechtsstelsels. Toch acht Drobnig het aanvaardbaar dat de 'International Encyclopedia of Comparative Law' de trust inpast in de continentale indeling van overeenkomstenrecht en goederenrecht, omidat deze encyclopedie de belangrijkste begrippen en functies van deze instelling in een afzonderlijk hoofdstuk beschrijft zodat de typische oplossingen die de trust biedt, volwaardig aan bod komen. Daarbij worden specifieke toepassingsgevallen naar AngloAmerikaans recht behandeld bij hun functionele tegenlhangers die zijn verspreid over de andere banden van de 'International Encyclopedia of Comparative Law', die de continentale benadering volgen ${ }^{78}$. Typische oplossingen moeten eerst worden vastgesteld en dan gedetailleerd ${ }^{79}$ worden beschreven; deze beschrijwing is beperkt tot de oplos-

72. Drobnig 1969,228 .

73. Drobnig 1969,229 .

74. Cf Drobnig 1986, 198 : macrovergelijking moet op intensieve nicrovergelijking gebaseerd zijn.

75. Drobnig 1969,230 .

76. Drobnig $1969,229-230$.

77. Drobnig 1972, 126. Inmiddels heeft de wetgever van Quebec aan de trust de benaning "fiducie" toegekend: ant 1260 BW van Quebec; of. Sacco, 29. Met deze "fiducie' is een begrip uit de common law geintroduceerd in een rechtsstelsel dat gerekend kan worden tot de civil taw. Overigens bevatten de continentale wetboeken belemmeringen voor een getrouwe nabootsing van de trust: of. Fratcher, $87,89,90$.

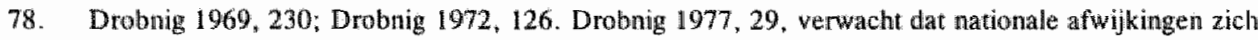
scherp aftekenen tegen het rechtsvergelijkende typebegrip. Zijn inspiratie is hier het ideaaltype van Weber: Drobnig 1977, 28.

79. Drobnig $1966,139$. 
singen die worden gebruikt door het representatieve rechtsstelsel ${ }^{20}$. Onder die voorwaarde kan voor de specifieke toepassingsgevallen aansluiting worden gezocht bij continentale classificatiesystemen.

Ad 3) Het standpunt van Constantinesco is niet helemaal helder en zal hierna behandeld. worden aan de hand van zijn kritiek op Drobnig. Deze kritiek bestaat uit twee punten. Het eerste punt van kritiek betreft het typebegrip van Drobnig. Volgens Constantinesco bieden typische oplossingen, zoals die van de trust, slechts een globaal overzicht wan een oplossing die min of meer gemeenschappelijk is aan meer rechtsstelsels: Dat overzicht mag een systematische vergelijking die is gericht op de exacte oplossing die een rechtsstelsel biedt, niet vervangen ${ }^{81}$. Deze kritiek is misplaatst. Bij de typische oplossingen van Drobnig gaat het om een selectie van oplossingen; de geselecteerde oplossing wordt niet in abstracto beschreven, maar als de oplossing die een specifiek rechtsstelsel biedt voor een sociaal probleem, bijvoorbeeld gebreken in verkochte zaken. Daarmee wil Drobnig het aantal te onderzoeken rechtsstelsels beperken ${ }^{82}$. Daaraan voegt hij toe dat een volledig begrip van een oplossing een discussie over de onderliggende verschillen vergt ${ }^{83}$.

Het tweede punt van kritiek betreft het classificatiesysteem van Drobnig. Dit classificatiesysteem is volgens Constantinesco ${ }^{84}$ ondoelmatig omdat de typische oplossingen van Drobnig losgemaakt zijn van de specifieke structuur van hun rechtsstelsel, omdat Drobnig geen recht doet aan de fundamentele verschillen tussen rechtsstelsels en rechtsfamilies, en omdat zijn classificatiesysteem beperkt is tot het privatrecht. Uit deze kritiek blijkt dat Constantinesco verlangt dat een classificatiesysteem rekening houdt met alle rechtsgebieden ${ }^{85}$ en met fundamentele verschillen tussen rechtsstelsels en rechtsfamilies. Het is echter niet geheel duidelijk hoe Constantinesco dit desideratum realiseert: volgens Constantinesco ${ }^{86}$ bestaat er een intersystematisch referentiesysteem ${ }^{87}$ dat

80. Drobnig 1969, 225; Drobnig 1972, 124. Rheinstein, 83 , stemt in net dese beperking tat typische oplossingen.

81. Constantinesco $1974,319$.

82. Drobnig 1972, 124. Volgens Drobnig 1977, 29, is het rechtswergelijkende typebegrip door sociologische factoren bepaald. Cf. Drobnig 1977, 30: het tertium comparationis is sociologisch.

83. Drobnig 1972, 125 .

84. Constantinesco 1983, 72-75.

85. Constantinesco 1983, 155-156, verwerpt een indeling van rechtsstelsels in rechtsfamilies die per rechtsgebied anders uitvalt.

86. Constantinesco 1983,421.

87. Daarnaast makk Constantinesco" 1974, 283-284, melding van een compatatief schema voor een rapport met resultaten van onderzoek naar onderdelen van rechtsstelsels. Cf. Kokkini 1988a, 187-188. 
mondiaal is, maar niet absoluut of supranationaal: Dit mondiale referentiesysteem is gebaseerd op determinerende elementen: onvervangbare, toonaangevende elementen die het mogelijk maken rechtsstelsels in rechtsfamilies in te delen ${ }^{88}$. Deze determinerende elementen zijn onder meer economisch en ideologisch van aard ${ }^{89}$.

Volgens Kokkini bezitten comparatieve begrippen direct nut in de aanvang van het rechtswergelijkende onderzoek; dat nut manifesteert zich in het vinden van een geschikt thema voor verder rechtsvergelijkend onderzoek. Overigens zijn de besproken auteurs niet expliciet over het direete nut van comparatieve begrippen. Sommigen leggen de nadruk op begin- of eindfase van het rechtsvergelijkend onderzoek, anderen op het samenstellen van een classificatiesysteem voor de presentatie van onderzoeksresultaten. In deze gevallen gaat het om rechtsvergelijkend onderzoek als doelstelling. De volgende paragraal behandelt mogelijkheden om comparatieve begrippen toe te passen buiten de rechtsvergelijking in enge zin.

\section{B. INDIRECT NUT:}

Comparatieve begrippen hebben niet alleen direct nut voor het rechtsvergelijkend onderzoek, maar kunnen ook nuttig zijn voor het vinden van documenten. In het geval van documentaire toepassingen is er eventueel sprake van indirect nut van comparatieve begrippen. Die toepassingen zullen eerst worden toegelicht. Vervolgens komt het mogelijke nut van comparatieve begrippen voor de beoefening van het internationaal privaatrecht aan de orde.

De Groot ${ }^{90}$ constateert dat het voor rechtsvergelijkend onderzoek en voor de grensoverschrijdende communicatie tussen juristen ideaal zou zijn indien men met een computer en via een uniforme thesaurus toegang zou kunnen verkrijgen tot de bibliografieën van andere rechtssystemen. Naar zijn overtuiging zou de verwerkelijking van deze droom door het ontwikkelen van een systeem van comparatieve begrippen worden bevorderd. De Groot ${ }^{91}$ meent dat het snel per computer opvragen van buitenlandse juridische documentatie is gediend met het opslaan van documentatie volgens een rechtsvergelijkend ontwikkeld classificatiesysteem, een juridische metataal met nummers die telkens refereren aan van nationale rechtssystemen geabstraheerde juridische categorieen. Een dergelijke metataal zou ook nuttig zijn bij het prepareren van juridische

88. Constantinesco $1972 b, 46,211$.

89. Constantinesco $1972 b, 215$; of. Van Reenen $1996,96-98$.

90. De Groot 1989, 28.

91. De Groot 1987, 23; cf. Drobnig 1969, 232. 
vertalingen ${ }^{92}$. Overigens tekent De Groot ${ }^{93}$ daarbij aan dat het creëren van een enigszins verfijnde metataal de krachtsinspanningen van enkele generaties rechtswergelijkers zou vergen. Er is weinig onderzoek verricht omtrent de ontwikkeling en realisering van een thesaurus van comparatieve begrippen ${ }^{*}$.

Kokkini ${ }^{95}$ ziet als een voordeel van bijzonder belang dat het samenstellen van een comparatief begrippenarsenaal, een Lexicon en een Thesaurus voor elke rechtsfamilie ${ }^{\% 6}$, kan bijdragen aan het ontwerpen van een internationale taal waardoor de rechtsvergelijkende onderzoeker toegang kan krijgen tot de geautomatiseerde documentatiebestanden van de verschillende landen. Deze toegang wordt eveneens nagestreefd door De Wild ${ }^{97}$ : deze auteur heeft een koppeling van verschillende juridische databanken voor ogen waarbij een Nederlandse jurist met gebruikmaking van begrippen uit het Nederlandse rechtssysteem, zou kunnen vragen met welke begrippen uit andere rechtsstelsels die begrippen corresponderen. Daartoe verlangt hij ${ }^{98}$ de ontwikkeling van gemeenschappelijke begrippen voor meertalige thesauri ${ }^{99}$. De Wild sluit niet uitdrukkelijk aan bij de uniforme thesaurus van De Groot, en evenmin bij de internationale taal van Kokkini.

92. De Groot 1987. 24; cf. Sacco, 27,31-32: abstracte, elementaire, gemeenschappelijke begrippen zijn nuttig voor het vertalen wan rechtstermen.

93. De Groot 1987, 24; cf. Van Laer 1987a, 19. De Boer 1992, 45, heef, gelet op de tijd die ermee gemoeid is, geen enkele fiducie in de onwikkeling van een internationale systematiek of wan een universele rechtsterminologie.

94. De Groot 1989, 21.

95. Kokkini 1985, 13 .

96. Zie II. $\$$ 4.B.

97. De Will, 26.

98. De Wild, 26,28 ; cf. 13,23 .

99. Door Mehl, 618-619, is geopperd dat de rechtsinfornatica cen epistemologische gids voor de rechtsvergelijking kan zijn. Voor het faciliteren van de toegang tot de bromen wan vreemde rechtsstelsels zou voor elk nationaal rechtsstelsel een thesaurus ontwikkeld en wertadld kunnen wordem: Meh!. 620-621. Bovendien acht Mehl, 622, een 'machine juridique comparatiste' mogelijk en zelfs wartschijnlijk. Deze machine zou voor een gestelde vraag de verschillende oplossingen verschaffen die door de uiteenlopende rechtsstelsels worden geboden; deze machine zou zodanig geprogrammeerd kunnen worden dat rechisgevongen worden afgeleid uit een werzaneling van complexe regels: Mehl, 623. Mits de machine bedoelde meertalige thesaurus bevat, kan de gebruiker de vraag in zijn eigen taal stellen: Mehl, 622. De 'machine juridique comparatiste" beoogt dus méér te zijn dan eun bibliografische databank met verwijzingen naar documenten: cf Mehl, 619. Het gaat Mehl om een rechtsvergelijkend expertsysteem voor het oplossen van rechtsproblemen. Het vinden van documenten ligt ten grondslag aan zijn rechtswergelijkende machine. Dit rechtswergelijkend expertsysteem zou in staat moeten zijin oplossingen woor een rechtswraag af te teiden wit werschillende rechtsstelsels dankzij een formalisering van de rechtstaal. Het deside ratum van $\mathrm{Meh}$ blifft buiten beschouwing: het formalise ren van redeneringen ten behoeve van een rechtswergelijkend expertsysteem gaat buiten het bestek van deze studie. 
Het indirecte nut van comparatieve begrippen manifesteert zich niet alleen in thesauri, maar ook in classificatiesystemen voor juridische documenten. Volgens De Groot ${ }^{100}$ zou een stelsel van juridische categorieën, geabstraheerd van nationale rechtssystemen, de grondstoffen kunnen leveren voor een classificatieschema voor juridische bibliotheken. Daarbij heeft hij ${ }^{101}$ een classificatieschema voor rechtsvergelijkende collecties op het oog: een dergelijk schema zou tegemoet kunnen komen aan de moeilijkheid dat de diverse rechtssystemen telkens andere verdelingen van rechtsgebieden vereisen door hun verschil in structuur. Dat classificatiesystemen een grondslag zouden kunnen bieden voor de indeling van collecties die literatuur van verschillende rechtsstelsels bevatten, is overigens een gedachte die ook door andere auteurs is geformuleerd: Zweigert/Kötz ${ }^{102}$ menen dat het presenteren van de resultaten van rechtsvergelijkend onderzoek evenals het catalogiseren van een bibliotheekcollectie met buitenlands recht naar zakelijke gebieden, om een internationale systematiek als grondslag vraagt.

De Groot ${ }^{103}$ meent bovendien dat een stelsel van juridische categorieën, geabstraheerd van nationale rechtssystemen, van nut zou zijn voor de beoefenaren van het internationaal privaatrecht: zij zien zich geconfronteerd met het probleem van de kwalificatie als situaties of rechtsregels door diverse landen uiteenlopend worden gekwalificeerd of als een buitenlands rechtsinstituut in het eigen land onbekend is ${ }^{104}$. Dat systemen met comparatieve begrippen een oplossing voor deze problematiek dichterbij zouden kunnen brengen, is een visie die ook is te vinden bij Mincke. Mincke ${ }^{105}$ signaleert dat de kwalificatieproblemen in het collisierecht gebaat zouden zijn met een taal ter beschrijving van vreemde rechtsstelsels. In dit verband verwijst hij ${ }^{106}$ naar Rabels ${ }^{107}$ pleidooi voor een universele taal met gemeenschappelijke rechtsbegrippen. Ook Kokkini verwijst in dit verband naar Rabel ${ }^{108}$ : zij ziet de autonome begripskwalificatie, zoals Rabel die voor het collisierecht heeft voorgesteld, als een hulpmiddel bij het formuleren van comparatieve begrippen die functioneel vergelijkbare rechtsinstituten zouden moeten dekken.

100. De Groot $1987,23-24$

101. Cf. De Groot 1987, 22 .

102. Cf. Zweigert/Kotz 1996,44 : zij nemen hier witd nukklijk afstand van een indeling 'nach Nationen'.

103. Cf De Groot 1987, 2324.

104. De Groot 1987, 21.

105. Mincke 1991, 464; cf. 448 .

106. Mincke 1984, 327.

107. Rabel 1931, 287: de rechtsvergelijking zou gemeenscharpelijke rechtsbegrippen kunnen ontwikkelen. Cf. Rabel 1958, 62: of. Zweigert/Kötz 1996, 6-7.

108. Kokkimi 1985, 10\%11. 
Samenvattend kan worden geconstateerd dat genoemde schrijvers zich positief uitlaten over het nut van comparatieve begrippen voor het winden van documenten en voor de oplossing van het kwalificatieprobleem in het international privaatrecht. Bovendien zouden juridische vertalingen baat kunnen hebben bij comparatieve begrippen; een algemene hypothese die niet wordt onderzocht in dit proefschrift. Daarbij past de kanttekening dat een systeem van comparatieve begrippen telkens wordt voorgesteld als een desideratum dat op realisering wacht.

\section{$\S$ 3. Begripsvorming}

\section{A. IMMANENTE BEGRIPSVORMING}

In de rechtsvergelijkende literatuur worden niet alleen veronderstellingen geopperd omtrent het nut van comparatieve begrippen, maar daarin word took aangeduid op welke wijze comparatieve begrippen gevormd zouden kunnen worden. In het laatste geval is de begripsworming aan de orde. De vorming van comparatieve begrippen zal worden onderscheiden in:

(1) immanente begripsvorming door begripsvereenvoudiging;

(2) extensionele begripsvorming door de selectie van gemeenschappelijke elementen;

(3) functionele begripsvorming door de abstractie van nationale rechtsbegrippen.

Immanente begripsvorming begint met de intensie van een nationaal rechtsbegrip; daarentegen komen nationale rechtsbegrippen niet onmiddellijk aan bod bij de extensionele en functionele begripsvorming.

Immanente begripsvorming is de wijze van begripsvorming die Sacco en Eltzbacher verdedigen. Dan worden comparatieve begrippen gevormd door de intensie van nationale rechtsbegrippen te vereenvoudigen. Eerst komt Sacco aan de orde, daarna wordt het standpunt van Eltzbacher behandeld.

Volgens Sacco ${ }^{109}$ is het voor de rechtsvergelijkende onderzoeker mogelijk om een abstract rechtsbegrip te vormen. Dit abstracte rechtsbegrip noemt hij een 'genotype' en de nationale rechtsbegrippen noemt hij 'fenotypen': empirisclie manifestaties van het genotype. Zo wordt het' genotype 'bezit' gekenmerkt door de feitelijke macht over een zaak en door een dienovereenkomstige rechtsbescherming, maar niet door "animus domini'. Dit laatste kenmerk kan ontbreken in het nationale rechtsbegrip, het fenotype. De aanwezigheid of afwezigheid van een dergelijk detail wordt bepaald door het natio-

109. Cf. Sacco, 26-27 
nale rechtsstelsel. Het genotype bevat twee conjuncte kenmerken; het is geen typebegrip maar een soortbegrip ${ }^{10}$ evenals dat van Eltzbacher.

Volgens Eltzbacher ${ }^{111}$ komen corresponderende begrippen tot stand door een abstractie van kenmerken van nationale rechtsbegrippen. Deze wijze van begripsvorming wordt hierna samengevat uitgaande van zijn driedeling van de rechtswetenschap ${ }^{112}$ :

(a) de wetenschappen van één rechtsstelsel en hun begrippen;

(b) de wetenschappen van én rechtsfamilie en hun begrippen;

(c) de algemene rechtswetenschap en haar begrippen.

Het geheel vormt volgens Eltzbacher ${ }^{113}$ een systeem van corresponderende ${ }^{1 / 4}$ soortbegrippen ${ }^{1 / s}$. Deze begrippen laten telkens een hoger abstractieniveau zien.

Zoals de wetenschap van een rechtsfamilie abstraheert van het begripskenmerk dat uitsluitend op één rechtsstelsel betrekking heeft, zo abstraheert de algemene rechtswetenschap van het begripskenmerk dat uitsluitend op éen rechtsfamilie slaat. In beide gevallen resteren begripskenmerken die onafhankelijk zijn van een rechtsstelsel respectievelijk van een rechtsfamilie ${ }^{116}$. Daarmee ontstaan volgens Eltzbacher ${ }^{117}$ telkens corresponderende begrippen: uitsluitend met de 'Gattungsbegriffe' van de wetenschappen van een rechtsfamilie corresponderen de begrippen van een rechtsstelsel; uitsluitend met de "Gattungsbegriffe' van de algemene rechtswetenschap corresponderen de begrippen van de beide overige rechtswetenschappen. Zo ontstaat bijvoorbeeld de volgende piramide van corresponderende begrippen: 'hoogverraad" van het Duitse recht, 'hoogverraad' van het recht van de Europese staten, 'hoogverraad' sec ${ }^{118}$. Het hogere soortbegrip bevat daarbij telkens het gemeenschappelijke kenmerk van de lagere begrippen; dankzij dat gemeenschappelijke kenmerk correspondeert het lagere met het hogere begrip ${ }^{119}$.

110. Zie II. 1 .

111. Leerling van R. von Jhering en van R. Stammler.

112. Eltzbacher, 39-42.

113. Dltzbacher, $49-50$.

114. Met de wijze van begripswoming die Eltzbacher werdedigt, kan het gewar zijn geweken dat het begrippenarsenaal der afzonderlijke rechtsstelsels niet correspondeert met een somparatief begrippenarsenal; dit gevaar wordt gesignaleerd door Sauveplanne 1975a, 37.

11.5. Etzbacher, 4748 .

116. Cf. Etzbacher, 44, 46,51-52,59. Afzonderlijke rechtsnormen zijn geen objecten van begrippen van de wetenschappen van een rechtsfamillie of van de algemene rechtswetenschap: cf. Eltzbacher, 44-45. Zo ook Kaden, 9: het is noodzakelijk dat de rechtsnomen die vergelleken worden, tot verschillende rechtsstelsels behoren; cf. Constantinesco 1974, 91.

117. Eltubacher, 48 .

118. Eltzbacher, 50. Eltzbacher schrijft over het recht anno 1900.

119. Cf. Eitzbacher, 51 . 
Hierbij passen twee kanttekeningen: Eltzbacher ${ }^{120}$ is de opvatting toegedaan dat een rechtsfamilie een willekeurigg ${ }^{121}$ geheel van rechtsstelsels is omdat een conceptueel selectiecriterium ontbreekt. De tweede kanttekening is dat de begrippen op de verschillende abstractieniveaus niet verwisselbaar zijn: valgens Eltzbacher ${ }^{122}$ bevatten de wetenschappen van een rechtsfamilie begrippen van de normen van die rechtsfamilie, die niet reeds door de wetenschappen van een afzonderlijk rechtsstelsel van die rechtsfamilie zijn gevormd. De algemene rechtswetenschap vormt op haar beurt slechts die begrippen van rechtsnormen, die niet reeds door de wetenschappen van rechtsstelsels of rechtsfamilies worden gevormd.

\section{B. EXTENSIONELE BEGRIPSVORMING}

De opvatting van Eltzbacher omtrent de vorming van comparatieve begrippen is niet de enige; er zijn andere standpunten ingenomen in de rechtsvergelijkende literatuur. Hierna wordt het standpunt van Rozmaryn besproken. Volgens Rozmaryn moeten er voor de vorming van comparatieve begrippen eerst gemeenschappelijke elementen worden geselecteerd ter concretisering van het toepassingsgebied van deze begrippen. De extensie met gemeenschappelijke elementen is het begin van de vorming van comparatieve begrippen zodat er sprake is van extensionele begripsvorming.

Volgens Rozmaryn ${ }^{123}$ moeten rechtsinstellingen die ook in andere rechtsstelsels worden aangetroffen en die daarmee gemeenschappelijk zijn aan een aantal rechtsstelsels, worden opgespoord. Deze rechtsinstellingen, complexen van rechtsregels ${ }^{124}$, zijn volgens Rozmaryn gemeenschappelijke elementen. Alle elementen die slechts nationaal zijn, zijn te beschouwen als variabele details: 'Est essentiel ce qui est commun' is zijn leidraad voor het vormen van comparatieve begrippen ${ }^{125}$. Volgens deze richtlijn blijven toevallige elementen, die slechts in één rechtsstelsel worden aangetroffen, buiten beschouwing als zijnde niet essentieel ${ }^{126}$. Rozmaryn licht dit toe met zijn voorbeeld van de 'rule of law' met rechtsinstellingen die beperkt zijn tot de westerse landen ${ }^{127}$.

120. Eltzbacher, 39 resp. 35 .

121. Zij het in verband met een volk of een deel van de aarde: Eltzbacher, 39. Bovendien kan eein rechtsfamilie wetenschappelijk bewerkt zijn: Eltzbacher ${ }_{n} 43-44.4$.

122. Eltzbacher, 39-40, 43, 45, 73-74.

123. Althans in een eerdere publicatie. Naar een latere publicatie wordt verwezen binnen het kader van II. 8 3.C.

124. Cf. Wróblewski, 92, 108 .

125. Rozmaryn 1958,70-71,74.

126. Rozmaryn 1958, 72 .

127. Rozmaryn 1958, 72, 74 . 
In dat woorbeeld somt hij ${ }^{128}$ zes essentiele of constitutieve elementen op die deze rechtsstelsels gemeenschappelijk hebben. De 'rule of law' bestaat volgens Rozmaryn uit de volgende zes instituties:

1) een verzameling van fundamentele rechten en van traditionele vrijheden en van hun traditionele garanties;

2) een verzameling van stabiele, samenhangende en algemene rechtsregels die bindend zijn voor de staatsorganen: zowel voor de uitvoerende macht als voor de wetgevende macht;

3) een onafhankelijke, stabiele rechterlijke macht die zich in de uitoefening van haar functies houdt aan algemene regels;

4) garanties voor een eerlijk proces voor de rechtbanken;

5) de noodzaak woor het bestuur om zich aan rechtsregels te houden;

6) een rechterlijke controle op bestuursdaden om te verzekeren dat die daden met de wet overeenstemmen.

Volgens Rozmaryn ${ }^{129}$ omvat het comparatieve begrip van de 'rule of law' instituties die ongewijzigd blijven door variabele details die zich in een rechtsstelsel kunnen voordoen. Buiten de instituties van de 'rule of law' vallen volgens Rozmaryn ${ }^{130}$ onder meer:

ad 1) de contractsvrijheid, de scheiding tussen kerk en staat;

ad 2) de wetgevende of jurisprudentiêle aard van die regels;

ad 3) de wijze van benoeming van de rechters; de methode van interpretatie die wordt toegepast door de rechters;

ad 4) de wijze van ondervraging; de bewijsmiddelen die zijn toegestaan; het bestaan van een jury;

ad 5) de juridische status van de 'examiners' in de Verenigde Staten of van de 'inspectors' in Engeland;

ad 6) de eventuele beperking van de rechterlijke controle tot rechtsvragen.

Het is aannemelijk dat Rozmaryn van de veronderstelling uitgaat dat alle moderne naties een aantal rechtsinstellingen als gemeenschappelijke elementen bezitten. Weliswaar verschillen deze rechtsinstellingen in hun details, maar het doel van de autonome rechtsvergelijking is de beschrijving van die gemeenschappelijke elementen ${ }^{131}$. Is er slechts

128. Rozmày 1958, 72-74.

129. Rozmaryn 1958, 74 .

130. Cf. Rozmaryn 1958, 72-74.

131. Cf. Arminjon/Nolde/Wolff, 29. Overigens nuken Arminjon c.s. in dit werband geen melding van comparatieve begrippen en worden Aminjon c.s. niet geciteerd door Rozmaryn. De owereenkomst in gedachtegang is niettemin frappant: het is annemelijk clat Arminjon c.s. Rozmaryn hebben beinvloed. 
een minimaal residu beschikbaar, dan is dat volgens Rozmaryn ${ }^{132}$ geen belemmering voor rechtsvergelijkend onderzoek. Niettemin streeft Rozmaryn naar een opsomming van alle elementen die gemeenschappelijk zijn aan de rechtsstelsels die tot het thema van een rechtsvergelijkend onderzoek worden gerekend ${ }^{133}$. Bij de comparatieve begrippen van Rozmaryn gaat het om het wezenlijke, en dit wordt gezien vanuit het gezichtspunt van het gemeenschappelijke zoals uit zijn reeds geciteerde richtlijn blijkt: 'Est essentiel ce qui est commun'. Als zijn richtlijn wordt opgevolgd, is volgens Rozmaryn '134 de betrekking tussen een comparatief begrip zoals de 'rule of law' en de nationale 'rule of law' immanent ${ }^{135}$. Deze immanente betrekking wordt door Rozmaryn verdedigd omdat hij niet wil weten van comparatieve begrippen waaraan een eigenmachtig bestaan wordt toegedicht: hij verwerpt een 'existence séparée' van comparatieve begrippen. De comparatieve begrippen worden volgens hem toegepast binnen de nationale rechtsstelsels; althans tot op zekere hoogte; daarbij zijn de comparatieve begrippen ${ }^{136}$ onderscheiden van de nationale instituties. Dit standpunt is een uitvloeisel van zijn bezwaren tegen de opvatting dat een comparatief begrip op voorhand alle noodzakelijke en essentiële kenmerken zou bevatten alvorens op een gegeven national rechtsstelsel te worden toegepast ${ }^{137}$.

Constantinesco ${ }^{138}$ verwerpt de zijns inziens onnauwkeurige en te algemene mening van Rozmaryn dat alleen gemeenschappelijke elementen wezenlijk zouden zijn. Constantinesco kan er weliswaar mee instemmen dat gemeenschappelijke elementen een institutionele gemeenschappelijke noemer in verschillende rechtsstelsels constitueren, maar differentiërende elementen mogen zijns inziens niet bij voorbaat buiten de vergelijking blijven. De kritiek van Constantinesco op Rozmaryn komt dus hierop neer dat Rozmaryn alle variabele details buiten beschouwing laat bij de vorming van een comparatief

132. Rozmaryn $1958,74-75$.

133. Rozmaryn 1958, 70.71.

134. Rozmaryn 1958, 71 : een aparte ideeünwereld wordt verworpen:

135. Daardoor is volgens Kokkini 1985, 12, de wrees van Sauvepdanne dal conparatieve begrippen een eigen leven gaan leiden, wiet gerechtwardigd.

136. Cf. Rozmaryn 1958, 70: comparatieve begrippen vormen de conceptuele structur van de rechusvergelijkende wetenschap.

137. Rozmary n 1958, 70. Overigens sluit Rozmary 1958, 74, niet uit dat in die mate afloreuk wordt gedan aan de essentiele elementen van zign comparatieve notie van de "rule of Haw' dat de daarutit voortvloeiende kwaltatieve wijzigingen worden weerspiegeld in deze comparatieve notie. Dat gevaar mag volgens hem nooit worden onderschat.

138. Traité de droit conparé. Tome II: La methode comparative, Paris 1974, is een bewerking van de oudere, Duitse tekst (Rechtsvergleichung. Band II: Die rechtsvergleichende Methode, Köln etc. 1972a). Hier wordt de Franse tekst aangehouden: $318-319$ en noot 154. 
begrip. Aan deze kritiek voegt Hall ${ }^{139}$ toe dat bij Rozmaryn niet uitgesloten is dat de gemeenschappelijke elementen vanuit cultureel oogpunt onbelangrijk zijn en dat Rozmaryn, afgezien van een verwijzing naar een gemeenschappelijke sociaal-economische structuur, niet aangeeft op welke grondslag hij de te vergelijken rechtsstelsels selecteert.

\section{FUNCTIONELE BEGRIPSVORMING}

Zweigert/Kötz streven maar de vorming van ruime 'Oberbegriffe' voor heterogene, maar functioneel vergelijkbare instituten. Elk 'Oberbegriff' vat een gemeenschappelijke functie samen ${ }^{140}$. Een voorbeeld van een functiebegrip is 'Seriositätsindizien' voor verbindende rechtshandelingen ${ }^{14 !}$. De comparatieve begrippen van Zweigert/Kötz zijn functiebegrippen. De sociale functie is volgens $\mathrm{Zweigert} / \mathrm{Köt} \mathrm{Z}^{142}$ het methodische grondbeginsel van elke rechtsvergelijking omdat slechts vergelijkbaar is wat in verschillende rechtsstelsels dezelfde taak, dezelfde functie vervult. De functie is het tertium comparationis, de vervulling van een juridische taak en de oplossing ${ }^{143}$ van een zakelijk probleem ${ }^{144}$. Dit tertium comparationis is sociologisch van aard en ligt buiten de vergeleken rechtsstelsels ${ }^{145}$. Tot het begrip functie behoren niet alleen het zakelijke probleem dat een rechtsinstelling moet oplossen, maar ook de oplossing die een rechtsinstelling feitelijk bewerkstelligt ${ }^{146}$. Het concrete zakelijke probleem is steeds de kern van elke rechtsvergelijking ${ }^{147}$. Elke samenleving stelt haar rechtsstelsel een identiek probleem tot tak ook al lossen de verschillende rechtsstelsels dat probleem op uiteenlopende wijze op ${ }^{448}$. Het sociale probleem dat moet worden opgelost met behulp van

139. Hall, $155-156$ noot 49.

140. Zweigert 1960, 199: Zweigert/Kötz 1996, 44.

141. Zweigert/Kotz 1996, 43-44; cf. Sauveplanne 1975a, 37: deze categorie omvat de geldigheidsvereisten voor overeenkomsten.

142. Kotz 1990, 209; Zweigert/Kötz 1996,33 . Dit is een postulalt: Zweigert 1973, 738.

143. Zweigert/Kotz 1984, 48: de 'totale" oplossing; dere toevoeging werd niet toegelicht. De betreffende passage ontbreekt in Zweigert/Kötz 1996.

144. Ook belangencontl ict of lewensprobleem genoend: Kotz 1990, 210; $\mathrm{cf}$. Zweigert/Kotz 1996, 11. Cf. Zweigert/Puttarken 1978, 404: sociaal-feitelijk probleem.

145. Drobnig 1977, 90; Zweigert/Kötz 1996, 11; cf. Mincke 1984, 323.

146. Cf. Zweigert 1969, 448; cf. Zweigert/Puttarken 1978, 402. Daarmee wordt het begrip functie vrijwel oneindig groot: Mincke 1984, 323 .

147. Zweigert/Kut 1996, 33.

148. Zweigert/Kotz 1996, 33; cf. Bartels, 90, 126. Overigens wordt onderkend dat voor een sociaal. probleem in het ene rechtsstelsel een juridische oplossing is voorzien, terwijl daarvoor in een ander land een niet-juridische oplossing bestant: Zweigert 1973, 749; Zweigert/Kötz 1996, 34, 37. 
rechtsregells ${ }^{149}$, zou een grotere mate van vergelijkbaatheid opleveren dan het juridische instrumentarium dat die oplossing dichterbij moet brengen ${ }^{150}$.

De systematische begrippen van het eigen rechtsstelsel mogen geen rol spelen bij de formulering van het te onderzoeken probleen en de oplossingen van de onderzochte rechtsstelsels moeten van alle systematische begrippen van deze rechtsstelsels bevrijd worden ${ }^{151}$. Er moet worden voorkomen dat het perspectief van de onderzoeker op het buitenlandse rechtsstelsel wordt beperkt door vooroordelen ontleend aan zijn eigen begrippenstelsel; er moet worden vermeden dat de onderzoeker een overeenkomstige regeling slechts op die systeemplaats zoekt waar hij die door zijn ervaring met het eigen recht verwacht ${ }^{152}$. Bij het opstellen van een werklhypothese in het begin van het rechtsvergelijkend onderzoek wordt volledig geabstraheerd van het nationale begrippenstelsel; men moet dan niet vragen 'welke vormvoorschriften kent het buitenlandse recht bij koopovereenkomsten?' maar 'hoe beschermt het buitenlandse recht partijen tegen overhaasting?' ${ }^{153}$. Juridisch-technische begrippen voor de oplossing van een levensprobleem en dogmatische constructies zijn variabel ${ }^{154}$. De nationale rechtsbegrippen bevatten volgens Zweigert/Kötz rechtstechnische criteria ${ }^{155}$ die niet voldoen aan de functionele criteria van 'Oberbegriffe'. Daarom moet het te onderzoeken probleem in eerste instantie geformuleerd worden in een neutrale omgangstaal, niet in de nationale vaktaal van een jurist ${ }^{156}$.

Zweigert/Kötz ${ }^{157}$ noemen hun benadering een radicale reductie naar de probleemoplossing in concreto, maar voegen daar onmiddellijk aan toe dat het van de bijzonderheden van het probleem in kwestie afhangt hoe die reductie er uitziet. Volgens hun standpunt is de vorming van comparatieve begrippen afhankelijk van het gemeenschappelijke

149. Rechtsregels zijn een middel voor de oplossing van een sociaal probleem, aldus Kotz mondelitig 12:11996.

150. Cf. Zweigert/Köz 1996, 45 .

151. Zweigert/Kotz 1996, 11,33, 43; cf. Zweigert 1973, 739; of. Zweigert/Puttfarken 1978, 404, 426.

152. Cf. Zweigert 1973, 739-740; cf. Zweigert/Kötz 1996, 33-34.

153. Zweigert 1973, 739; Zweigert/Köt 1996, 33; of. Kötz 1990, 209.

154. Kotz 1990, 210; cf. Zweigert 1973, 754 .

155. Zseigert/Kötz 1996, 43.

156. Kötz 1990, 209-210, cf. Zweigert/Kötz 1996, 11; cf. Van Reenen 1995, 189, 193. Overigens heeft Kötz op 12-1-1996 mondeling toegegeven dat het onmogelijk is de juridische vaktail volledig te vermijden.

157. Zweigert/Kotz 1984, 49. Deze passage ontbreekt in Zweigert/Kotz 1996. 
gezichtspunt van een identiek rechtsprobleem ${ }^{158}$. Zij beweren dat de functies van rechtsinstellingen begrepen en adequaat beschreven kunnen worden zonder naar rechtsbegrippen te verwijzen ${ }^{15 \%}$. Aan het functionele 'Oberbegriff' van Zweigert/Kồtz ligt de weronderstelling ten grondslag dat een vergelijking niet mogelijk wordt gemaakt door rechtsbegrippen maar door functies ${ }^{169}$. Functies zijn vergelijkbaar omdat ze door sociale problemen bepaald zijn ${ }^{16 !}$. Hun functionele benadering wordt ingegeven door een reactie op de Begriffsjurisprudenz ${ }^{162}$. Daarmee verzetten zij zich tegen een overheersende rol van rechtsbegrippen ${ }^{163}$ die kan leiden tot de introductie van nieuwe regels ${ }^{164}$. Rechtsbegrippen mogen niet worden verheven tot een rechtsbron waaruit rechtsregels worden afgeleid zonder te letten op de maatschappelijke consequenties ${ }^{165}$. In het geval wan een dienende rol van rechtsbegrippen bestaat niet het gevaar ${ }^{166}$ dat comparatieve begrippen een eigen leven gaan leiden.

Zweigert/Kötz ${ }^{167}$ verwerpen een dienende rol van rechtsbegrippen niet. Juridische clogmatiek is een nuttig oriëntatiemiddel waar de juridische dogmatiek de stof doelmatig ordent, maar komt pas na de functionele beginvraag aan de orde ${ }^{16 \%}$. Na de conclusie dat verschillende rechtsstelsels verwante oplossingen bevatten, is de rechtsvergelijker geïnteresseerd in de details van de dogmatiek die de juridische oplossing van een afzon-

158. Cf. Rozmaryn 1973,583-585: er moet worden gezocht naar zoveel mogelijk gemeenschappelijke, identieke eigenschtappen die essentieel zijn vanuit het gezichtspunt van de sociale functie van de rechtsinstellingen, om die rechtsinstellingen vergelijkbaar te doen zijn. Daarmee getuigt Rozmaryn 1973 van een andere benadering dan Rozmarym 1958 zonder dat deze auteur aangeeft of hij zijn eerdere opwarting will aanwullen met zijn latere, postuum werschenen publicatie.

159. Cf. Hall, 106, 109 .

160. Cf. Bsser, 352. Anders: Sauveplanne 1981, 16: bij de rechtsvergelijking gaat het om de functies die

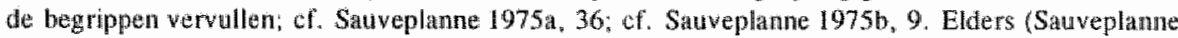
$1975 \mathrm{a}, 28-29,37)$ ziet hij te verge lijking van tuncties ats het noodzakellijk complement wan de vergelijking der rechtsbegrippen.

161. Cf. Esser, 357.

162. Zweigent/Kölz 1996, 140; cf. Constantinesco 1974, 37: autonome comparatieve begrippen bevatten het risico slechis Begriffsiurisprudenz te zijm.

163. Cf. Rodriguez Mol linero, 125.

164. Cf. Loth $1990,5-7$.

165. Loth 1991, 110-111. Cf. Zweigert 1977a, 159, 167; de evaluatie van een juridische oplossing van een buitendands rechtsstelsel moet aandacht schenken aan het sociale effect wan die oplossing. Cf. Esser, 298: de functionele methode is athistorisch.

166. Sauveplame 1975a, 37.

167. Kötz $1990,204,210,213,214$. Cf. Zweigert 1969, 448: de functionele methode is antidogmatisch.

168. Kötz 1990, 209-210, 212. Volgens een brief (6-12-1995) van Kötz an de auteur van dit proefschrift moeten de systematische begrippen in een tweede fase onderzocht worden. 
derlijk rechtsstelsel laten zien ${ }^{169}$. In de laatste lase van het onderzoek moet worden getoetst of de gevonden juridische oplossingen inderdaad in functioneel opzicht verwant zijn $^{170}$. Eventueel wordt de werkhypothese van de beginfase weerlegd.

De kritiek van Constantinesco ${ }^{17}$ op het bovenstaande luidt als volgt: internationale begrippen zoals $Z$ weigert/Kötz die opvatten, zijn te ver verwijderd van de realiteit van de nationale regelgeving. Dergelijke abstracte begrippen gaan naar zijn mening voorbij aan de differentia specifica die de oplossingen van elke rechtsorde karakteriseert ${ }^{172}$. Aangaande een gemeenschappelijke rechtsinstelling met dezelfde functie in verschillende rechtsstelsels is het standpunt van Constantinesco ${ }^{173}$ dat het betreffende gemeenschappelijke begrip beperkt blijft tot een fundamentele functie die niet identiek is voor elk rechtsstelsel afzonderlijk: de ontstaansgronden en de bestaansvoorwaarden, de juridische techniek waarmee die rechtsinstelling gerealiseerd wordt, en de rechtsgevolgen kunnen per rechtsstelsel tot op zekere hoogte verschillen. Zo is het begrip 'overeenkomst" vanuit een formeel gezichtspunt weliswaar gemeenschappelijk aan alle rechtsstelsells, maar de overeenkomst heeft in de socialistische rechtsfamilie een heel andere functie dan in de Europese rechtsfamilie ${ }^{174}$. Constantinesco is van mening dat Zweigert/Körz het 'Oberbegriff' te globaal ${ }^{775}$ opvatten. Dit punt van kritiek kan worden toegelicht met de vraagstelling die Zweigert/Kötz kiezen: 'hoe beschermt het buitenlandse recht partijen tegen overhaasting?' Hierin ontbreken 'vormvoorschriften' en 'koopovereenkomsten'. Aan hun vraagstelling beantwoordt ook de consumentenbescherming met bijvoorbeeld een afkoelingsperiode ${ }^{176}$. De beginvraag van Zweigert/Kötz is niet gericht op rechtsproblemen, maar op sociale problemen. Deze sociale problemen moeten niettemin leiden naar de rechtsregels die in de vergelijking worden betrokken.

Constantinesco ${ }^{177}$ bestrijdt vervolgens het postulaat van $\mathrm{Zweigert/Kötz} \mathrm{dat} \mathrm{rechtspro-}$ blemen in alle landen identiek zijn omdat de sociale behoeften overal dezelfde zouden

169. Zweigert 1973,754.

170. Zweigert 1973, 755-756; Zweigert/Kötz 1996, 39.

171. Constantinesco 1974, 323.

172. Kokkini 1985, 12, acht het bezwaar van Constantinesco ongegrond ondat een comparatief begrip het vinden van een probleemoplossing in een national rechtsstelsel niet overbodig matkit.

173. Constantinesco 1974, 314 .

174. Constantinesco 1974, 318. Hier blijft buten beschouwing hoe de socialistische rechtsfamilie afgebakend kon worden van de Europese rechtsfamilie.

175. Cf. Constantinesco 1974, 86 noot 121; cf. Constantinesco 1983, 69.

176. Cf. Schmidt, 9, 17.

177. Constantinesco 1983, 63 . 
zijn: dat postulaat ${ }^{178}$ miskent volgens Constantinesco de grote diversiteit van rechtsproblemen en de verschillen tussen primitieve en post-industriële samenlevingen ${ }^{179}$. Specifieke behoeften ${ }^{180}$, variëren met de aard van de samenleving. Bovendien zijn rechtsproblemen niet het rechtstreekse gevolg van sociale behoeften omdat nationale regeringen naar eigen opvattingen interveniëren in de relatie tussen sociale behoefte en rechtsprobleem ${ }^{181}$. Rechtsstelsels zijn slechts vergelijkbaar voor zover de wetgever dezelfde behoefte wil bevredigen ${ }^{182}$. Volgens Constantinesco ${ }^{183}$ is het 'Oberbegriff' van Zweigert/Kötz niet universeel. De sociale werkelijkheid vestigt geen tertium comparationis ${ }^{1 \% 4}$. Zweigert/Kötz gaan niet in op de kritiek van Constantinesco. Het ontbreken van discussie blijkt uit de opmerking dat Constantinesco onvoldoende duidelijk zou zien dat het 'so oft gesuchte und lange unentdeckte tertium comparationis' in der Rechtsvergleichung die Funktion ist' ${ }^{\text {sas. }}$.

\section{\& 4. Rechtstermen voor comparatieve begrippen}

\section{A. VERSCHILLEN IN GEBRUIK}

Het vormen van een comparatief begrip impliceert de keuze van een rechtsterm om dat begrip weer te geven. Comparatieve begrippen zijn mededeelbaar dankzij begripsrepresentatie: het vastleggen van een begrip met een rechtsterm. De keuze van een geschikte rechtsterm voor het weergeven van een comparatief begrip is echter problematisch: als rechtsstelsels vergeleken worden, manifesteren zich verschillen in het gebruik van rechtstermen (II.\$ 4.A) en in de betekenis van rechtstermen (II.\& 4.B). Mincke bespreekt het verschil in gebruik van nationale rechtstermen. Volgens Mincke valt een

178. Cf. Drobnig 1986, 196-197, 199.

179. Dit Iatste punt van kritiek is overigens niet helemaal terech: Z weigert/Purfarken, 402 , wijzen erop dat een sociaal probleem miet zonder meer op dezelfde wijze bestat in economisch ontwikkelde en minder ontwikkelde samenlevingen. $\mathrm{Cl}$. Z weigent 1973, 738, 752, 756, cf. Zweigert/Kötz 1996, 39; cf. Rheinstein, 13, 26. Bowendien beperken Z weigert/Kötz zich in hun hoofdwerk tot westerse rechtsstelsels: Rheinstein, 82. Volgens een mondelinge toelichting vatn Kötz op 12-1-1996 wordt de functionele beginwrag niet begreper in primitiewe samentevingen. $\mathrm{Cr}$. Zweigert $1977 \mathrm{a}_{0} 156$ : verondersteld wordt dat het beschavingsniveau wan minder antwikkelde landen zich onder meer in hun rechtsstelsels manifesteert:

180. Bijvoorbeeld de sociale behoeften eigen aan de culturele dimensie van de mens: Constantinesco 1983. 65 .

181. Constantineseo 1983, 66-67.

182. Cf. Wähler, 219.

183. Cf. Constantinesco 1983, 70, 74-75.

184. Constantinesco 1974, 38 .

185. Zweigert $1977 \mathrm{~b}, 176$. 
begrip samen met het correcte gebruik van de daarbij behorende term in de context wan een afzonderlijk rechtsstelsel ${ }^{186}$. Dit uitgangspunt brengt hem tot de keuze dat zuiver gemeenschappelijke rechtsbegrippen worden weergegeven door elementaire rechtstermen met een absoluut identieke betekenis. Het radicale standpunt van Mincke wijkt af van het gematigde standpunt van Kokkini en Drobnig (II. \$ 4.B): zij zien in rechtstermen die in betekenis verschillen, geen onoverkomelijke beperking voor het weergeven van comparatieve begrippen.

Volgens Mincke staan rechtstermen voor individuele objecten. Volgens hem ${ }^{187}$ kan men "enrichissement sans cause" vertalen met 'ongerechtvaardigde verrijking', maar het object achter de term, de rechtsinstelling is in het geheel niet identiek. Zelfs voor een linguïstisch gezien identieke term zoals 'ungerechtfertigte Bereicherung' geldt dat het object niet exact hetzelfde is: de onderliggende regels van het Oostenrijkse recht verschillen van die van het Duitse recht ${ }^{198}$. Als men ervan uitgaat dat met het Nederlandse begrip 'ongerechtvaardigde verrijking' de Nederlandse regels worden bedoeld, en met het Duitse begrip 'ungerechtfertigte Bereicherung' de Duitse regels, dan hebben deze begrippen betrekking op een ander object omdat het gaat om per rechtsstelsel afwijkende regels ${ }^{189}$. Mincke ${ }^{190}$ licht vervolgens toe dat rechtstermen verwijzen naar individuele objecten: de woorden 'Eigentum' en 'Ehe' duiden als rechtstermen objecten aan die slechts in één rechtsstelsel, bijvoorbeeld het Duitse ${ }^{191}$, voorkomen. In het recht stellen we immers de vraag of een huwelijk geldig is volgens de toepasselijke regels, bijvoorbeeld die van het Duitse recht. Daarom staat de vertaalbaarheid in "property" respectievelijk 'marriage' principieel ter discussie. Van dit vertaalprobleem is men zich bewust in het geval van rechtstermen die gewoonlijk onvertaald blijven zoals de trust: deze eigennaam betreft een object dat niet alleen individueel is voor het Engelse recht, maar waarvoor buiten het Engels geen geschikte ${ }^{192}$ woorden beschikbaar zijn ${ }^{193}$. Nationale rechtstermen weerspiegelen te beschrijven objecten die van individuele aard

186. Cf. Barberis, 7.

187. Mincke 1991, 447. Uit de context blijkt dat thij geen meertalig rechtsstelsel zoals het Belgische. op het oog heeft. Het gaat om het geval dat de andere taral tevens de taal van een ander rechissysteem is todat toepassingsvoorwaarden en rechtsgevalgen verschillen; cf. Mincke 1987, 108-109.

188. Mincke 1991, 450

189. Mincke 1987, 109; cf. David 1992, 69.

190. Mincke $1991,459$.

191. Of het $Z$ witserse of het Oostenrijkse rechtsstelsel: beide rechtsstelsells hanteren eveneens het Duits alls rechtstaall.

192. Volgens Mincke 1991, 460, zijn nieuwe, buitenlandse woorden voor trust verwarrend.

193. Mincke 1991, 459. Barberis, 11: het betreffende rechtsstelsel doet rechtstermen voor unieke rechis. instellingen onvertaalbare eigennamen zijn. $\mathrm{Cf}$. Riesthuis/Wijnands, 89: een eigemaarm is een exclusieve aanduiding. 
zijn: de individuele, nationale regels zijn volgens Mincke ${ }^{194}$ noch te beschrijven, noch te vergelijken. Wanneer de individuele, nationale rechtsinstellingen slechts kunnen worden benoemd of getoond, treft de geschetste beperking van onze woordenschat uiteindelijk de rechtsvergelijking zelf, die daarmee een niet te beschrijven object zou thebben 195 .

Het vertalalprobleem dat zich bij juridische teksten voordoet, leidt Mincke tot de fundamentele vraag natar de relatie tussen taal en werkelijkheid ${ }^{195}$; vallen de grenzen van de werkelijkheid samen met de grenzen van de taal ${ }^{197}$ ? Dan zou elk rechtsstelisel een gesloten werkelijkheid zijn. of is er een universeel object dat onafhankelijk van de taal bestaat in die zin dat het object identiek is voor Fransen, Nederlanders, Oostenrijkers en Duitsers? Als een algemeen begrip van een universeel object zou bestaan, zou dat verklaren thoe we de nationaal verschillende objecten wan de taalvarianten van 'ongerechtvaardigde verrijking' in de werkelijkheid kunnen waarnemen en relateren. Als een begrip beschikbaar zou zijn dat boven de te vergelijken objecten staat, kunnen de objecten beschreven worden met dat begrip als criterium. Zodra een begrip optreedt in de vergelijking, wordt het tot dan toe individuele een bijzondere vorm van iets algemeens ${ }^{198}$.

Op zoek naar algemene begrippen voor universele objecten heeft Mincke ${ }^{199}$ zich bezig gehouden met de speciale aard van die rechtsbegrippen die van toepassing lijken op meer dan eén rechtssysteem en die wellicht zelfs universeel zijn. Hij onderscheidt 'beschrijvende begrippen' waarmee men het objectieve recht differentieert, van 'normatieve begrippen' die voor een complex van normen staan. Het is aannemelijk dat Mincke daarmee aangeeft dat de toepassingscriteria of vooronderstellingen van beschrijvende begrippen afwijken van die van normatieve begrippen ${ }^{200}$. Voorbeelden van de eerste eategorie zijn volgens hem: 'subjectief recht', 'objectief recht' en 'overeenkomst'; voorbeelden van de laatste categorie zijn 'eigendom' en 'huwelijk'. Met de beschrijvende begrippen zouden rechtsinstellingen van verschillende rechtsstelsels vergelijkend

194. Mincke 1984, 317.

195. Cf. Mincke 1984, 321 .

196. Cf. Mincke 199॥, 451.

197. Wittgenstein, 89: (5.6) "Die Grenzen meiner Sprache bedeutendie Grenzen meiner Welt"; $\mathrm{cf}$. Wittgenstein, 16: (2.063) 'Die gesamte Wirklichkeit ist die Welt".

198. Cf. Mincke 1984, 322.

199. Mincke 1991 462. Hij vernijdt overigens de uitdrukking 'comparatieve begrippen': cf. Mincke 1984, 326-327.

200. Cf. Herberger/Sinon, 291. 
beschreven ${ }^{201}$ kunnen worden, tenzij ze zijn gebonden aan een rechtsstelsel op de wijze van normatieve begrippen. Het verschil in gebondenheid aan rechtsstelsels is bepalend voor het onderscheid tussen beschrijvende begrippen en normatieve begrippen.

De beschrijvende begrippen overschrijden de grenzen van een rechtsstelsel niet volledig waar het Duitse en het Zwitserse recht in het voorbeeld van "koop" een andere indeling van de rechtsstof kennen in verband met verschillen tussen de ingedeelde objecten ${ }^{202}$ : de Duitse abstracte leer maakt de eigendomsoverdracht helemaal los van de koopovereenkomst, terwijl een geldige koopovereenkomst in Zwitserland voorwaarde voor de eigendomsoverdracht kan zijn. Mincke kan echter niet volledig verklaren waarom de Duitse rechtsstof in dit geval verschilt van de Zwitserse rechtsstof. Het verschil betreft hier miet zozeer de rechtsbegrippen 'koopovereenkomst' en 'eigendomsoverdracht', maar veeleer de mogelijkheid deze begrippen te combineren ${ }^{203}$. Een ander gebruik van rechtstermen impliceert volgens Mincke dat de complete rechtsstof verschillend is. De Duitse abstracte leer scheidt volgens Mincke ${ }^{204}$ het verbintenissenrecht van het goederenrecht zodat het onmogelijk is om 'koopovereenkomst' te combineren met 'eigendomsoverdracht" ${ }^{\text {; }}$ het Zwitserse rechtsstelsel mist deze combinatiemogelijkheid niet. Volgens Mincke ${ }^{205}$ ontbreken er elementaire rechtstermen die dit verschil kunnen uitdrukken zonder gebruik te maken van Duitse of Zwitserse normatieve begrippen. Het consensusbeginsel verklaart volgens hem onvoldoende zodra het Franse rechtsstelsel in de vergelijking wordt betrokken. Het consensusbeginsel is erkend in het Franse recht, maar het Franse recht onderschrijft de abstracte leer niet. In het Franse recht geschiedt eigendomsoverdracht met het sluiten van de koopovereenkomst. Het consensusbeginsel speelt in het Franse recht een andere rol dan in het Duitse recht. Mincke verlangt blijkbaar dat verklaard wordt hoe verschillende combinatiemogelijkheden herleid worden op beschrijvende begrippen die constant zijn ${ }^{206}$.

De beschrijvende begrippen zijn van toepassing op meer rechtsstelsels en wellicht universeel ${ }^{207}$. Daarbij signaleert Mincke ${ }^{208}$ de volgende problemen: bedoelde be-

201. Mincke 1984, 324; cf. Mincke 1984, 322 .

202. Mincke 1984,325 .

203. Mincke 1984, 326: "Wirkungszusammenhang won Rechtsgeschaffen", Cf. Von Jhering, 334-335: combinatie valn grondbegrippen of elementen van het recht.

204. Mincke 1984,325 .

205. Cf. Mincke 1984, 326 .

206. Overigens heeft Mincke op 25-10-1995 de mogelijkheid erkend dat rechtsvergelijking geschiedt met 'generaliserende begrippen' die in zijn opvatting geen beschrijvende begrippen zijn.

207. Mincke 1991, 462.

208. Mincke 1991, 462. 
schrijvende begrippen zijn voor zover bekend niet ontwikkeld tot een systeem; en er is geen omvattende terminologie om rechtsinstellingen te beschrijven. Dit leidt hem tot de vraag of een rechtsstelsel met de linguistische middelen van een ander rechtsstelsel kan worden beschreven. Zijn antwoord op deze vraag is dat daartoe een bovengeschikt niveau geconstrueerd moet worden, een aan de rechtsstelsels gemeenschappelijke taal met elementen waarop hun rechtsinstellingen te herleiden zijn ${ }^{209}$. Deze gemeenschappelijke taal die Mincke als oplossing ziet, is een universele metataal ${ }^{210}$. Een metataal $^{211}$ zou gerealiseerd moeten worden in een vergelijkende analyse ${ }^{212}$, bestaat uit begrippen waarin de nationale talen kunnen opgaan, bevat als fundamentele elementen alle objecten watuit 'recht' samengesteld kan zijn en toont de bouwstenen waaruit alle rechtsstelsels zijn samengesteld ${ }^{213}$. Een volledige metataal is een desideratum.

\section{B. VERSCHILLEN IN BETEKENIS}

Het standpunt van Mincke leidt ertoe dat comparatieve begrippen beperkt blijven tot de begrippen die worden weergegeven met elementaire rechtstermen die voor bijna alle rechtsstelsels bruikbaar zijn. Dit is een beperkter standpunt dan in deze paragraaf aan de orde wordt gesteld. Dit ruimere standpunt staat toe dat verschillend gebruik van

209. Mincke 1991, 463; cf. Mincke 1984, 322; cf. Mincke 1991, 465.

210. Behalve Mincke streeft Mehl naar de ontwikkeling van een metataal. Mehl, 624, acht het waarschijnlijk dat er fundamentele begrippen bestaan die gemeenschappelijk zijn aan alle rechtsstelsels. Volgens Mehl suggereert een grondige analyse van de gebruiksvoorwarden van woorden als "personnes physiques" het bestaan van een verborgen strucnutr van het rechtsdenken. Deze structuur bestaat volgens Mehl wit eerste begrippen die onbenoemd en deels onbewust zün. Hij komt na classificerende vingeroefenimgen ten aanzien wan het woord "personnes physiques', tot het fundamentele rechtsbegrip 'entitê": Mehl, 624-625. Dit begrip behoort volgens Mehl tot de latente structuur van het rechtsdenken. Deze structuur is volgens $\mathrm{Mehl}_{1} 620$, niet de heterogene structuur die de verschillende rechisstelsels ten opzichte van elkaar manifesteren, zeker niet wanneer die rechtssystemen opgebouwd zijn vanuit conceptuete elementen zonder equivalent daabuiten. Die heterogene structuur is de voornamste moeilijkheid die de rechtsvergelijker zou willen ophelderen en bedwingen. Daaron zoekt Mehl, 621, naar een structun die het mogelijk maakt tenzelffle semantische inhoud te lierkennen zonder dat daaraan aforeuk wordt gedaan door woordwarianten zoals synonymie. Als oplossing stelt Mell, 626-627, woor de rechtstaal minstens gedeeltelijk te formaliseren om te komen tot een systeem van gemeenschappelijke symbolen. Daabij stat hem het model van de wiskunde voor ogen. De aldus geformaliseendle taal zou de rechtsnoimen moeten uitdrukken: Mehw, 623. De wiskundige symbolen van deze kunstmatige metataal zouden comparatieve begrippen zoals 'entité kunnen weergeven zonder hinder te ondervinden wan woordvarianten in natuurlijke talen.

211. Zie 11.1 .

212. Cr. Von Jhering, 349-351: anallyse van rechtsinstellingen levert elementen.

213. Cf. Mincke 1984, 327-328. 
rechtstermen gepaard gaat met een gemeenschappelijke betekenis ${ }^{2 t, 4}$. Comparatieve begrippen kunnen door rechtstermen gerepresenteerd worden indien de intensie algemeen is, niet indien het gebruik algemeen is zoals Mincke verlangt. Verschillen in betekenis maken de keuze van rechtstermen niettemin problematisch. In dit verband zijn de volgende overwegingen van Kokkini, Drobnig en Constantinesco van belang.

Kokkini ${ }^{215}$ veronderstelt dat een rechtsvergelijkend begrippenapparaat onder meer het directe nut toekomt de onderzoeker tijd te besparen door terminologische voetangels te vermijden. Kokkini ${ }^{216}$ is tamelijk concreet in het aangeven van de weg waarlangs een comparatief begrippenstelsel ontwikkeld zou kunnen worden. $\mathrm{Zij}^{217}$ stelt het volgende werkplan en de volgende werkwijze voor: eerst worden relevante rechtstermen geïnentariseerd door juristen uit dezelfde groep rechtsorden ${ }^{2 ! 8}$; deze termen worden geclassificeerd in wat zij een Lexicon noemt. Daarbij is de vooronderstelling van Kokki$\mathrm{ni}^{219}$ dat een zekere consensus onder de vergelijkers is ontstaan met betrekking tot de groeperingen van de rechtsstelsels in rechtsfamilies met subgroepen. Het Lexicon bevat volgens het voorstel van Kokkini niet alleen een inventarisatie en classificatie van rechtstermen, maar ook een vergelijking ten aanzien van de begrippen die al dan niet corresponderen met de geselecteerde termen. Daarbij onderscheidt Kokkini ${ }^{220}$ de volgende vier gevallen:

a) voor alle rechtsorden van dezelfde groep zijn de termen letterlijk ${ }^{221}$ gelijk; de termen drukken relatief identieke begrippen uit;

b) alle rechtsorden van dezelfde groep bezitten gemeenschappelijke begrippen ${ }_{\text {, }}$ doch de benaming ervan verschilt;

214. Cf. Loth 1986,246 .

215. Zie II. 2.A.

216. Kokkini 1985, 9-13, is nagenoeg identiek aan Kokkini 1988a, 78, 90-93.

217. Kokkini 1988a, 91-92.

218. Het werkplan van Altamira, $237-238$, voor het samenstellen van een vijftalige woordenschat, begint eveneens met de selectie van relevante rechistermen door een aantal personen. Vervolgens zou een commissie de verschillende taalvarianten aan een rechtsvergelijkende studie moeten onderwerpen. Het kan noodzakelijk zijn dat aan bedoelde inventarisatie voorafgiaat dat de nationale termen worden afgebakend door middel van interne rechtsvergelijking: cf. Rayar, $73,87$.

219. Kokkini 1985, 9; Kokkini 1988a, 90. Cf. David 1992, 15; de grondslagen wan de classificaties wan rechtsstelsels lopen uiteen.

220. Kokkini 1985, 10; Kokkini 1988a, 91.

221. Kokkini laat hier taalvarianten en vertalproblemen buiten beschouwing. Die komen pas aan de orde bij de vertaling van het Lexicon en de Thesaurus, waarvan elders sprake is: Kokkini 1985, 12. Er worden in eerste instantie onvertaalde termen geïnventariseerd. 
c) de termen zijn weliswaar letterlijk identiek, maar ze dekken begrippen die tenminste gedeeltelijk verschillend zijn ${ }^{222}$;

d) de termen of begrippen van een bepaalde rechtsorde bezitten geen parallel in de andlere rechtsorden van dezelfde groep ${ }^{223}$.

Op de gevallen (a) tot en met (d) wordt ingegaan na de bespreking van het derde stadium van het werkplan van Kokkini.

In het tweede stadium wordt hetgeen Kokkini een Thesaurus noemt, gevuld met comparatieve begrippen die door vergelijking worden geformuleerd uit de elementen van de gegeven juridische fenomenen die tot de rechtsorden van dezelfde groep behoren. Daarbij poneert ze ${ }^{224}$ dat een comparatief begrip een globaal overzicht geeft van een antal nationale begrippen die fundamentele gemeenschappelijke kenmerken hebben; dit is een formulering die overeenkomt met die van Eltzbacher. Omdat ze bovendien de indruk wekt dat ze het comparatieve begrip van de 'rule of law' van Rozmaryn als exemplarisch beschouwt ${ }^{225}$, zou echter ook verondersteld kunnen worden dat Kokkini hier met Rozmaryn een selectie van gemeenschappelijke elementen verkiest. Kokkini onderschrijft verder de begripsvorming van Zweigert/Kötz waar ze streeft naar de formulering van comparatieve begrippen die voldoende ruim zijn geformuleerd om rechtsinstituten te dekken die hoewel heterogeen toch vergelijkbaar zijn op grond van hun functie ${ }^{226}$. In het kader wan het Lexicon en de Thesaurus stelt Kokkini 'functie' gelijk met 'taak' ${ }^{227}$ ondat het Lexicon en de Thesaurus het inleidende onderzoek dienen. In het inleidende onderzoek gaat het bij de functie om de identieke of equivalente taak ${ }^{228}$; in de systematische fase van het rechtsvergelijkende onderzoek gaat het volgens Kokkini om de reële werking of het effect van een rechtsinstituut of rechtsregel ${ }^{229}$. Ofschoon Kokkini dat niet expliciet vermeldt, is het aannemelijk dat de Thesaurus evenals het Lexicon een classificatie van termen bevat. Dan maakt de Thesaurus gebruik van de classificatie in het Lexicon. Daarbij blijft in het midden om welke

222. Gutteridge, 118, ziet een groot gevar voor rechtsvergetijkende studies in identieke termen die in andere rech tsstelsels verschillende rechtsinstituten aangeven.

223. Een variant op het ontbreken van een paraltel is dat in de andere rechtsorden rechtsinstituten worden aangetroffen die qua functhe uiteenlopen: Kokkini 1985, 10; Kokkini 1988, 91. David 1992, 12, acht een gebrek aan correspondentie tussen nationale begrippen een grote moeilijkheid voor de rechtsvergelijkende onderzoeker. Cf. Leluto, 152-153; als de ene rechtstaal een begrip mist, dat in de andere rechtstalal wordt gebruikt, ontbreken er equiwallente begrippen.

224. Kokkini $1985,12$.

225. Kokkini 1985, 11-12; Kokkini 1988a, 92; cf. Kokkini 1988b, 231, 241.

226. Kokkini 1985; 10; Kokkini 1988a, 92.

227. Kokkini 1988a, 91-92.

228. Cf. Kokkini 1988b, 238.

229. Kokkini 1988a, 136-137. 
classificatie het gaat; Kokkini verwijst niet naar de classificatiesystemen van Zweigert/Kötz, Drobnig of Constantinesco ${ }^{230}$.

In het derde stadium komt Kokkini bij het vraagstuk van de weergave van comparatieve begrippen waar zij opmerkt dat aan de comparatieve begrippen eventueel nieuwe, maar ook wel bestaande nationale benamingen kunnen worden gegeven ${ }^{231}$. Kokkini werkt niet uit in welke gevallen bestaande nationale benamingen geschikt zijn om comparatieve begrippen weer te geven. Geschikte benamingen zijn wellicht de letterlijk identieke termen van de gevallen (a) en (c) die in het kader van het Lexicon zijn opgevoerd. Het is onduidelijk welke geïnventariseerde termen geschikt zijn voor de representatie van comparatieve begrippen. Niettemin vertegenwoordigt Kokkini het standpunt dat de intensie van comparatieve begrippen kan worden uitgedrukt in rechtstermen. In het stadium van het Lexicon wordt al onderzocht in hoeverre begrippen corresponderen met rechtstermen. Dan zijn er volgens Kokkini vier mogelijkheden: (a) relatief identieke begrippen; (b) gemeenschappelijke begrippen; (c) tenminste gedeeltelijk verschillende begrippen; (d) begrippen zonder parallel. Geval (a) valt echter samen met geval (b) of (c); het is althans niet duidelijk wat geval (a) onderscheidt van geval (b) of (c) ${ }^{232}$. Omdat er in geval (d) geen sprake kan zijn van comparatieve begrippen, resteren er bij Kokkini uiteindelijk twee mogelijkheden ofwel gemeenschappelijke begrippen met verschillende termen, ofwel gedeeltelijk verschillende begrippen met identieke termen. $\mathrm{Zij}$ vermeldt niet de volgende varianten: gemeenschappelijke begrippen met identieke termen; gedeeltelijk verschillende begrippen met verschillende termen. Dit is een omissie tenzij Kokkini deze gevallen om een of andere reden wil uitsluiten van haar Lexicon. Niettemin huldigt Kokkini een ruimer standpunt dan Mincke ${ }^{233}$ omdat ze toestaat dat niet alleen gemeenschappelijke maar ook gedeeltelijk verschillende begrippen weergegeven worden met rechtstermen.

Kokkini streeft naar een classificatie van nationale rechtstermen; Drobnig zoekt naar uniforme termen die veelal nieuw zijn. Drobnig ${ }^{234}$ is ervan overtuigd dat overwegingen van rechtsvergelijkende aard vooraf dienen te gaan aan de vastlegging van uniforme

230: Zie II. \& 2.A.

231. Kokkini 1985, 11; Kokkini 1988a, 92. Deze keuze kon niet aan de orde komen in thet inventariserende stadium van het Lexicon dat geen nieuwe benamingen bevat ondat het Lexicon is beperkt tot bestande termen.

232. Vermoedelijk zün de 'relatief' identieke begrippen (a) "bijna" of 'praktisch' identiek, dat wil zeggen: minder uiteenlopend dan tenminste (!) gedeeltelijk werschillende begrippen (c).

233. Zie ll. $\$$ 4.A.

234. Drobnig 1969, 233. 
termen. $\mathrm{Hij}^{235}$ ziet zijn standpunt bevestigd in de werkzaamheden voor de "International. Encyclopedia of Comparative Law" die als nevenproduct de bouwstenen, althans de grondslagen voor een uniforme terminologie geleverd zouden hebben. In dit verband signaleent Drobnig ${ }^{236}$ de volgende typische problemen bij de voor de Encyclopedia onmisbare schepping ${ }^{237}$ van cen uniforme terminologie in de Engelse ${ }^{238}$ taal:

a) rechtshegrippen zoals 'jurisprudence' hebben een totaal verschillende intensie al naargelang de taal en de rechtsordle: Misverstanden zijn hier slechts te voorkomen door volledig af te zien van het gebruik van dergelijke woorden. Het Engelse respectievelijk Franse woord 'jurisprudence' moet worden vervangen ten behoeve van het formuleren van uniforme termen 239 ;

b) een rechtsbegrip zoals "guter Glaube" dat tot verschillende rechtsstelsels behoort, bezit naast een identieke intensie nog een bijzondere intensie ${ }^{240}$. Of het nu gaat om dezelfde (linguistische) taal zoals in dit voorbeeld of om verschillende talen zoals het Engels of het Frans, aan een dergelijk rechtsbegrip kan geen eenduidige internationale betekenis worden toegekend. Uitkomst biedt volgens Drobnig slechts de duidelijke aanwijzing in welke betekenis het begrip ${ }^{241}$ telkens gebruikt wordt: in de betekënis van een of ander rechtsstelsel, of in een algemeen vergelijkende betekenis;

c) er moeten nieuwe Engelse termen gevormd worden voor al die begrippen van nietEngelse rechtsstelsels, waarvoor het Engels geen eigen vertalingen beschikbaar heeff ${ }^{242}$. Wanneer als oplossing voor dit probleem 'Rechtsgeschäft' wordt vervangen door 'legal transaction', moet de nieuwe rechtstechnische betekenis van deze laatste term worden toegelicht. Als een vervangend woord ontbreekt, is een beknopte omschrijving niet te vermijden;

d) zo mogélijk nog meer delicaat is het creëren van neologismen voor die rechtsinstituten waarvoor het Engelse en Amerikaanse recht geheel verschillende uitdrukkingen gebruiken ${ }^{243}$. Voor bijvoorbeeld 'corporation' dan wel 'share company' zou als nieuwe kunstmatige uitdrukking 'markelable share company' geïntroduceerd kunnen worden

235. Drobnig 1969, 231 .

236. Drobnilg $1969,232-233$.

237. Drobnig 1972, 127 .

238. Drobnig 1966, 140 en Drobnig 1972, 117. de Encyclopedia wordt in het Engels gepubliceerd om het grootst nogelijke gehoor te bereiken.

239. Drobnig 1972, $12 \%$.

240. Drobnig 1972, 127 : andere juridische implicaties.

241. Dat wil zeggen het vertalde begrip, ondat Drobnig geen soelaas verwacht van het niet vertalen van dergelijke begrippen.

242. Drobnig 1972, 127: die onbekend zijn aan Engelse juristen.

243. Cf. David 1992, 341: cf. Kisch, 214.215. 
als de keuze van één van beide begrippen onmogelijk is. Deze nieuwe, neutrale ${ }^{244}$ term kan volgens Drobnig echter slechts mondiaal worden begrepen als daarbij de functie van de te vervangen begrippen zo aanschouwelijk mogelijk wordt beschreven.

Drobnig ziet evenals Kokkini het probleem dat een rechtsbegrip geen parallel heeft in een ander rechtsstelsel; daarvan getuigt categorie (a) van Drobnig. Categorie (a) mist een comparatief begrip in tegenstelling tot categorie (c) waarvoor het Engelse rechtsstelsel geen term bevat. Verder onderkent Drobnig met Kokkini dat een gemeenschappelijke intensie vergezeld kan gaan van een bijzondere intensie zoals blijkt uit de categorieën (b) en (d) van Drobnig; ook hier doen zich comparatieve begrippen voor. De term 'guter Glaube' is letterlijk identiek voor verschillende rechtsstelsels;' in categorie (d) ontbreken termen die letterlijk identiek zijn. Anders dan Kokkini vermeldt Drobnig niet de mogelijkheid van zuiver gemeenschappelijke begrippen. Anders dan Kokkini geeft Drobnig sub (c) en (d) voorbeelden van nieuwe, internationale termen in én linguistische taal: het Engels.

Drobnig signaleert vier verschillende gevallen waarin het creëren van een uniforme terminologie problematisch is. Omtrent het streven van Drobnig merkt Constantinesco ${ }^{245}$ op dat het ontwikkelen van een nieuwe juridische terminologie slechts gerechtvaardigd is voor zover de nationale rechtsterminologie ongeschikt is om nieuwe comparatieve begrippen uit te drukken; volgens Constantinesco bezitten internationale rechtstermen slechts bestaansrecht waar ze niewwe begrippen weergeven. Constantinesco beperkt het bestaansrecht van nieuwe rechtstermen tot nieuwe begrippen die geen nationale bestanddelen bevatten. Volgens Constantinesco ontbreekt een supranationale rechtsterminologie, die autonoom is en ontdaan van elk nationaal bestanddeel. Een uniforme terminologie acht hij in beginsel mogelijk binnen één rechtsfamilie; Constantinesco ziet af van universele termen voor elementaire begrippen zoals 'recht' en 'rechtvaardigheid' omdat hun betekenis fundamenteel verschilt per rechtsfamilie. Constantinesco is zeer terughoudend ten aanzien van nieuwe termen ter vervanging van nationale rechtstermen; dit betreft vooral de categorieèn (a) en (c) waarin sprake is van verschillende rechtsfamilies waarvoor volgens Constantinesco geen uniforme rechtstermen mogelijk zouden zijn. Waar geen sprake is van nieuwe begrippen is het gebruik van een nationale rechtsterm, bijvoorbeeld "ungerechtfertigte Bereicherung' of 'enrichissement sans cause', als een gemeenschappelijke rechtsterm mogelijk en noodzakelijk. Daarmee lijkt Constantinesco in te stemmen met de oplossing die Drobnig voor categorie (b) geeft, terwijl hij de oplossing voor categorie (d) zou moeten verwerpen. Nationale rechtstermen zijn

244. Drobnig 1972, 127.

245. Cf. Constantinesco $1974,314-315$. 
weliswaar niet uniform, maar ze zijn volgens Constantinesco geschikt voor de weergave wan comparatieve begrippen met nationale bestanddelen.

\section{\$ 5. Besluit}

Het woorafgaande is een zo volledig mogelijke inventarisatie van de verschillende standpunten omtrent comparatieve begrippen. Tezamen roepen deze standpunten verschillende vragen op. Het is de vraag of immanente vorming van comparatieve begrippen even goed verdedigbaar is als extensionele of functionele begripsvorming. Weliswaar zijn de besproken auteurs positief over het direete nut van comparatieve begrippen, maar alleen Kokkini is daarin expliciet. Niet alle standpunten zijn zonder meer verenigbaar. Kokkini en Z weigert/Kötz beweren dat comparatieve begrippen nuttig zijn voor de beginfase van het rechtsvergelijkende onderzoek, terwijl Constantinesco het houdt bij de eindfase. Comparatieve begrippen zouden ook nuttig zijn voor het samenstellen van een classificatiesysteem voor de presentatie van onderzoeksresultaten, maar daaromtrent is er evenmin consensus in de besproken literatuur. Er is ook een controverse over de keuze van geschikte rechtstermen voor het weergeven van comparatieve begrippen. Het indirecte nut van comparatieve begrippen voor het vinden van documenten en voor de oplossing van het kwalificatieprobleem in het internationaal privaatrecht berust op desiderata die wellicht niet gerealiseerd kunnen worden. Er is eerst een eigen standpunt nodig ten aanzien van de verschillende voorwaarden watonder comparatieve begrippen nut hebben voor het rechtsvergelijkende onderzoek. Nadat deze voorwaarden geformuleerd zijn, kan het indirecte nut van comparatieve begrippen onderzocht worden.

Op het bovenstaande zal het plan van behandeling van de problematiek van comparatieve begrippen aansluiten. In hoofdstuk III zal het mogelijke nut van comparatieve begrippen worden onderzocht om te komen tot een eigen standpunt aangaande het directe nut van comparatievè begrippen. Het indirecte nut komt in de hoofdstukken IV, V en VI aan de orde; deze hoofdstukken gaan over de toepassingsgebieden van comparatieve begrippen. Na hoofdstuk III volgt een bespreking van rechtswergelijkende ordeningssystemen (hoofdstuk IV). Daarna komen rechtsvergelijkende thesauri (hoofdstuk V) aan de orde, gevolgd door een bespreking van de rechtsvergelijkende begripskwalificatie in het international privaatrecht (hoofdstuk VI). In hoofdstuk VII zullen conclusies worden getrokken ten aanzien van het directe en indirecte nut van comparatieve begrippen. 


\section{Mogelijk nut van comparatieve begrippen}

\section{\$1. Aanpak voor dit hoofdstuk}

De in hoofdstuk II besproken literatuur vraagt om een eigen standpunt omtrent het nut van comparatieve begrippen. Daarvoor zijn twee redenen. De eerste reden is dat de literatuur niet duidelijk maakt welke wijze van begripsvorming de voorkeur verdient. De tweede reden is dat in de literatuur verschillende onderzoeksactiviteiten genoend worden waarvoor comparatieve begrippen nuttig zouden zijn. Daarom behandelt hoofdstuk III de voorwaarden waaronder comparatieve begrippen nuttig zijn voor verschillende onderzoeksactiviteiten. Elke onderzoeksactiviteit is medebepalend voor het directe nut. Dit hoofdstuk is beperkt tot het directe nut van comparatieve begrippen, met uitzondering van de laatste paragraaf waarin drie mogelijke toepassingsgebieden aan de orde komen.

Het uitgangspunt is dat comparatieve begrippen nuttig zijn woor een vergelijkbaarheidsoordeel: een hypothese die getoetst moet kunnen worden aan verschillende rechtsstelsels in de werkelijkheid ${ }^{246}$. Een comparatief begrip wordt hier opgewat als een conceptueel criterium voor de vergelijkbaarheid van rechtsregels. Dit criterium bezit empirisch nut indien de toetsing van een vergelijkbaarheidsoordeel mogelijk wordt gemaakt. Deze toetsing kan vanaf de beginfase of pas in de eindfase van het onderzoek plaatsvinden.

246. Zie II.\& I. 
In het eerste geval moet een rechtsvergelijkende methode ${ }^{247}$ gekozen worden die geschikt is voor de toetsing van een vergelijkbaarheidsoordeel, bijvoorbeeld de functionele methode voor een hypothese met een functiebegrip ${ }^{248}$. In het tweede geval wordt het vergelijkbaarheidsoordeel getoetst in de eindfase zodat het gevaar bestaat dat dan pas voldaan wordt aan het fundamentele methodologische vereiste 'te vergelijken wat vergelijkbaar is "249. Daarom is het van belang om na te gaan of comparatieve begrippen empirisch nut hebben vanaf de beginfase van het onderzoek. Dit gebeurt in III. \$2.A. Hierin wordt kritiek geleverd op het standpunt van Constantinesco dat de vergelijkbaarheid van rechtsregels gegeven is met de objecten waarop een rechtsvergelijkende methode wordt toegepast. Zijn standpunt bevat het risico dat aanvankelijk vergeleken wordt wat onvergelijkbaar blijkt in de eindfase. Comparatieve begrippen kunnen dit risico wegnemen indien ze eenduidig zijn zodat in de eindfase hetzelfde begrip ${ }^{250}$ optreedt als in de beginfase. De extensionele begripsvorming van Rozmaryn voldoet niet aan deze voorwaarde omdat hij het onderzoek laat beginnen met een verzameling elementen waarvan niet eenduidig vaststaat in welk opzicht zij vergelijkbaar zijn.

Functiebegrippen en immanente begrippen zijn bruikbaar vanaf de beginfase van het onderzoek. De keuze tussen functiebegrippen en immanente begrippen is niet willekeurig. Deze keuze wordi bepaald door de onderzoeksactiviteit die beoogd wordt. Het beschrijven van rechtsregels van verschillende rechtsstelsels stelt andere eisen dan het toetsen van een vergelijkbaarheidsoordeel. Het verklaren van dogmatische verschillen tussen rechtsstelsels stelt weer andere eisen dan het beschrijven van rechtsregels. Daarom wordt in III.\$2.B onderzocht onder welke voorwaarden comparatieve begrippen nuttig zijn voor het beschrijven van rechtsregels of het verklaren van dogmatische verschillen. In deze paragraaf wordt de vraag beantwoord of het functiebegrip van

247. Er is geen rechtsvergelijkende methode die algemeen anvaatd is of algemeen atavarard zou noeten worden: of. Bartels, 90; $\mathrm{cf}$. Whithler, $211.212,219$. Cf. Zweigert/Kotz 1996, 32: een 'gesicherter Methodenkanori ontbreekt. Hier wordt verondersteld dat er zodanige methodologische regels worden gevolgd dat de toetsing van een vergelijkbaartheidsoordeel niet op willekeurige wijze geschiedt. De toetsing van vergelijkbaarheidsoordelen wind plaats binnein de rechtswergelijking in enge zin: of. De Groot 1989, 2.

248. Immanente begrippen gaan gepand met het hanteren van niet-functionele methodes van rechtsvergelijking of. De Boer 1994, 309: conceptuele, 'begrifflich-dogmatische' en institutionele methodes. De keuze van geschikte methodes van rechtswergelijkend onderzoek kan hier in het midden bljijven omdat dere keuze mede wordt bepaald door de beoogde toepassing wan onderzoekstesultaten: $c f$. Wâhter, 211, 224. Daarbij past de katuttekening dat de stelling dat toegepaste rechtswergelijking is gediend met een functionele benadering terwijl niet-functionele methodes op kennisvermeerdering zijn gerichat, te absolut is: of. De Boer 1994, 309.

249. Dit vereiste wordt genoend door Kokkini in II.\$2. A.

250. Cf. Herberger/Simon, 261. 
Zweigert/Kötz voldoende specifiek is voor het beschrijven van rechtsregels van verschil lende rechtsstelsels. Dezelfde vraag wordt gesteld voor het functiebegrip van Drobnig. Het standpunt van Mincke dat comparatieve begrippen geschikt moeten zijn voor het verklaren van dogmatische verschillen wordt eveneens in III.\$2.B aan de orde gesteld.

De toetsbaarheid van het vergelijkbaarheidsoordeel dat een functiebegrip of een immanent begrip bevat, komt aan de orde in III. $\$ 3 . A$ en III. $\$ 3 . B$. Toetsbaarheid is een noodzakelijke voorwaarde voor het empirisch nut van comparatieve begrippen. De toetsbaarheid van een vergelijkbaarheidsoordeel is de mogelijkheid tot bevestiging of weerlegging van dit oordeel ${ }^{251}$. Of aan deze voorwaarde wordt voldaan, moet blijken uit de toetsing aan de eigenschappen ${ }^{252}$ wan de vergeleken rechtsregels. Als daaraan niet getoetst kan worden, mist het comparatieve begrip empirisch nut. De waarheid van het oordeel dat de regels van bijvoorbeeld het Nederlandse appartementsrecht vergelijkbaar zijn met die omtrent het Duitse Wohnungseigentum ${ }^{253}$ mag niet bepaald worden door subjectieve vooronderstellingen ten aanzien van de werkelijkheid ${ }^{354}$. In dit verband past het onderscheid tussen oordelen met functiebegrippen (III.\$3.A) en oordelen met immanente begrippen (III.\$3.B). In het eerste geval blijft het nationale begrippenstelsel buiten beschouwing, in het tweede geval niet. De functionele begripsworming elimineert subjectieve vooronderstellingen ontleend aan nationale rechtsbegrippen waarmee de onderzoeker het meest vertrouwd is. De immanente begripsvorming ontleent kenmerken aan de vergeleken begrippenstelsels. Dit vestigt de indruk dat vergelijkbaarheidsoordelen met functiebegrippen toetsbaar zijn in tegenstelling tof oordelen met immanente begrippen. Deze indruk zal genuanceerd worden.

Het is voorts de vraag of comparatieve begrippen nuttig zijn voor onderzoeksactiviteiten als het samenstellen van een rechtsvergelijkend classificatiesysteem (III.\$ 4.A) of het ontwikkelen van een eenduidige terminologie (III. \$ 4.B). Deze presentatievormen moeten het mogelijk maken nieuwe vergelijkbaarheidsoordelen te relateren aan beschikbare onderzoeksresultaten ${ }^{255}$ om te voorkomen dat elk onderzoek met een tabula rasa

251. Oordeten kumnen waar zijn, begrippen niet: begrippen kunnen nuttig zijn: of. Kuflen 1977, 20, 100.

252. Cf. Hage 1986, 502, 505.

253. Zie II $\$ 1$.

254. Subjectieve vooronderstellingen ten aanzien van de werkelijkheid mogen niet bepalend zijn voor de toepassing van comparatieve begrippen op rechtsregels. Dit laat onverlet dat de onderzoeker een comparatief begrip kan kiezen voor zijn onderzoeksthema : vanuit persoonilijke belangstelling of beleidsmatige prioriteiten beslist de onderzoeker welke rechtsregels hij relewant acht. Daarbij speelt de ervaring van de rechtsvergelijker ook een rol. In die $z$ in is een subjectief perspectief onvermijdelijk.

255. Cf. Mincke 1993, 175. 
moet beginnen ${ }^{256}$. Waar resultaten van voltooid onderzoek berusten op vergelijkbaarheidsoordelen die bevestigd zijn, ligt het voor de hand de comparatieve begrippen in deze vergelijkbaarheidsoordelen te gebruiken voor het samenstellen van een rechtsvergelijkend classificatiesysteem of het ontwikkelen van een eenduidige terminologie. Daarmee staat nog niet vast onder welke voorwaarden functiebegrippen of immanente begrippen nuttig zijn ter voorkoming van misverstanden omtrent voltooid onderzoek. De presentatie van onderzoeksresultaten stelt andere eisen dan het toetsen van vergelijkbaarheidsoordelen of het beschrijven van rechtsregels.

Aan het eind van dit hoofdstuk wordt de aandacht gevestigd op de volgende toepassingsgebieden van comparatieve begrippen: rechtsvergelijkende ordeningssystemen, rechtsvergelijkende thesauri, en de rechtsvergelijkende begripskwallificatie in het IPR. Het is aannemelijk dat comparatieve begrippen indirect nut hebben woor genoemde toepassingsgebieden: rechtsvergellijkende ordeningssystemen en thesauri zijn presentatievormen voor gedocumenteerde onderzoeksresultaten en beogen hetzelfde doel als rechtsvergelijkende classificatiesystemen en een rechtsvergelijkende terminologie. Comparatieve begrippen zijn nuttig voor rechtsvergelijkende ordeningssystemen en thesauri indien zij eraan bijdragen dat documenten gevonden worden die relevant zijn voor het rechtsvergelijkende onderzoek. Ook voor de begripskwalificatie in het IPR kunnen comparatieve begrippen nuttig zijn: comparatieve begrippen die de toetsing van vergelijkbaarheidsoordelen en de beschrijving van rechtsregels dienen, bevatten geen waardeoordeel ${ }^{25}$. Comparatieve begrippen zijn nuttig voor de" rechtsvergelijkende begripskwalificatie indien ze niet leiden tot een voorkeur voor de juridische oplossing die eén van de vergeleken rechtsstelsels biedt voor het geschil dat beslecht moet worden.

In III.\$ 5.A zal voorlopig worden geconcludeerd dat de drie toepassingsgebieden resultaten van rechtsvergelijkend onderzoek bevatten zodat deze gebieden in aanmerking komen voor de toepassing van comparatieve begrippen. In III. \& 5.B wordt overwogen dat het indirecte nut van comparatieve begrippen afhankelijk is van beperkingen inherent aan de toepassingsgebieden.

256. Het ontbriken van een vabula rasa is van belang ongeacht of met onderzoeksresultaten kennisverineerdering wordt beoogd of de verbetering van wetgeving. Kenniswermeerdering en de werbetering. van wetgeving zijn geen doelstellingen van comparatiève begrippen: zie hoofdstuk I.

257. Kokkini 1988a 179, acht een waarde-oordeel terecht overbodig woor comparatieve begrippen. De kritische wardering wan juridische oplossingen behoort niet tot het tertium comparationis: De Groot/Sclaneider, 62. Of het vervangen van nationale regelgeving door vergelijkbare oplossingen van elders, leidt tot een rechtwaardiger resultaat, kan niet met comparatieve begrippen bepaald worden omdat deze begrippen geen maatstaven verschaffen woor een dergelijke waardering. 


\section{§ 2. Vergelijken en beschrijven}

\section{A. COMPARATIEVE BEgRIPPEN IN DE BEGINFASE}

Constantinesco ${ }^{258}$ beweert dat comparatieve begrippen geen nut hebben in de beginfase van het onderzoek. De te onderzoeken objecten zijn volgens hem vergelijkbaar voordat de rechtsvergelijkende methode wordt toegepast. Comparatieve begrippen worden volgens hem pas getoetst in de eindfase van het onderzoek. De vergelijkbaarheid van de onderzoeksobjecten mag volgens Constantinesco niet worden bepaald door een sertium comparationis omdat dit een subjectief criterium zou zijn ${ }^{259}$. Volgens Constantinesco is er tot de eindfase geen plaats voor een comparatief begrip. Hij miskent de objectiviteit van een vergelijkingsbasis: een criterium voor de vergelijkbaarheid van rechtsregels ${ }^{260}$, een begripskenmerk waarop de vergelijking betrekking heeft ${ }^{261}$. Tot de eindfase van het onderzoek zou een comparatief begrip geen empirisch nut hebben.

Het standpunt van Constantinesco dat comparatieve begrippen overbodig zijn in de beginfase van het onderzoek, lijkt op het eerste gezicht te verdedigen. In de situatie dat er geen relevant ${ }^{262}$ onderzoeksresultaat beschikbaar is, is geheel onduidelijk in welk opzicht rechtsregels vergelijkbaar moeten worden geacht. Het onderzoek kan bijvoorbeeld beginnen met de wettelijke definities van het Nederlandse appartementsrecht en het Duitse Wohnungseigentum ${ }^{263}$. De vergelijking van deze definities kan aanvankelijk het intuîtieve begrip 'mede-eigendom' opleveren ${ }^{264}$; dan zijn de kenmerken van het comparatieve begrip nog onbekend ${ }^{265}$. Het intuïtieve begrip 'mede-eigendom' maakt niet duidelijk in welk opzicht de regels omtrent het appartementsrecht vergelijkbaar geacht worden met die omtrent het Duitse Wohnungseigentum.

258. Zie II. 8 . A

259. Cf. Kaufmann, 36: de keuze van het tertium comparationis is beslissend voor hei perspectief van de vergelijking.

260. Cf. De Groot/Schneider, 62; cf. Van Reenem 1995, 181. 198.

261. De GrootMedendorp, 71. Het tertion comparationis is conceptueel van aard: Mincke 1984, 322.

262. Cf. Kokkini 1988a, 132: tertia comparationis zijn zelden tevoren geformuleerd.

263. Zie hoofdstuk I.

264. Uit de wettelijke definities blijkt overigens ook dat er een verschil is tussen het appartementsrecht en het Wohnungseigentum: de appartementseigenaar heeft slechts een gebruiksrecht ten aanzien van zijn appartement, terwijl het Duitse rechtsstelsel hier eigendom toekent. Zie III. $2, \mathrm{~B}$ voor verschillen ussen rechtsregels.

265. Cf. Huppes, 178 . 
In de beginfase verwacht een jurist een bepaalde betekenis ${ }^{260}$ als hij een buitenlandse rechtsterm ziet, maar een terminologische overeenkomst kan misleidend zijn ${ }^{267}$. Het is niet noodzakelijk dat de Duitse rechtsterm 'Feststellungswertrag' dezelfde betekenis heeft als de Nederlandse : vaststellingsovereenkomst" ${ }^{268}$. Een intuïtief begrip staat niet toe om vergelijkbaarheid of onvergelijkbaarheid vast te stellen. Een intuitief begrip heeft geen enipirisch nut omdat een vergelijkbaarheidsoordeel dat een intuittief begrip bevat, niet toetsbaar is. Daarentegen is een vergelijkbaarheidsoordeel met een comparatief begrip toetsbaar omdat de kenmerken van dat begrip geëxpliciteerd zijn.

De opvatting van Constantinesco bevat het gevaar dat het vergelijkbaarheidsoordeel met een comparatief begrip pas in de eindfase weerlegd wordt omdat de onderzochte objecten niet vergelijkbaar blijken. Hiervoor waarschuwt Kokkini ${ }^{269}$ terecht: in de eindfase kan een verkeerde keuze in de beginfase niet meer ongedaan gemaakt worden. Een comparatief begrip in de beginfase kan tijdverspilling voorkomen door bij te dragen aam het formuleren van een uitgangshypothese die beantwoordt aan het fundamentele methodologische vereiste om te vergelijken wat vergelijkbaar is ${ }^{270}$. In tegenstelling tot Constantinesco ${ }^{271}$ is Kokkini terecht van mening dat comparatieve begrippen bruikbaar zijn in de aanvang van het rechtsvergelijkende onderzoek. De veronderstelling van Constantinesco dat vergelijkbaarheid gegeven is met de objecten waarop de rechtsvergelijkende methode ${ }^{272}$ wordt toegepast, leidt tot de verwerpelijke consequentie dat in

266. Cf. Van Laer $1978,262-263$

267. Volgens Kokkini (11. $\$ 2 . A$ ) helpen comparatieve begrippen terminologische voetangels te vermijden.

268. Meijers 1948, 112: de bedoeling van partijen kan verschil maken; Meijers 1972, 1133: het rechtskatrakter van de vaststellingsovereenkomst is zeer onstredien in de literatuur. In de Duitse literatuur bestaut geen consensus ten atazien van thet begrip 'Feststellungsvertrag'; Rizmamn, 7.

269. Zite 11.82.A.

270. Overigens is volgens Kokkini een vergelijking zonder comparatieve begrippen mogelijk. Dat blijkt uit haar Lexicon dat een vergelijking van nationale rechtsbegrippen bevat: zie II.\$4.B. Dit Lexicon bevat geen comparatieve begrippen in tegenstelling tor haar Thesaurus die in het volgende stadium wordt gevald met comparatieve begrippen die door vergelijking worden geformuleerd.

271. Het verschil tussen beide opvattingen ligt niet zozeer in de fase van het rechtsvergelijkend onderzoek: de eerste onderzoeksfase van Kokkini onnat de eindfase van Constantinesco. Zie Constantinesco 1974, 122 123, Kokkini 1988a. 145, 155; of. Florijn, 148-149. De exacte afbakening wan fases van onderzoek blift hier buiten beschouwing. Beslissend voor het verschil tussen Constantinesco en Kokkini is dat tot de eindfase van Constantinesco een rechtsvergelijkend perspectief ontbreekt.

272. Hat toepassen wan een rechtswergelijkende methode op een verzameling objecten makt weliswaar intersubjectief controleerbatr welke objecten in het onderzoek zijn betrokken, maar is geen rechtvarardiging van de vergelijkbaarheid van de opgesomde objecten. Er is behoefte aan een conceptueel criterium voor de vergelijkbaarheid van rechtsregels voordat de rechtsvergelijkende methode wordt toegepast. 
de beginfase niet vast komt te staan in welk opzicht rechtsregels vergelijkbaar worden geacht.

Niet alleen het gebruik van intuïtieve begrippen, maar ook de aanwijzing van het onderzoeksthema door middel van een opsomming van rechtstermen ${ }^{273}$ laat impliciet in welk opzicht rechtsregels vergelijkbaar worden geacht. Ook extensionele begripsvorming komt voor in de beginfase van het onderzoek. Deze begripsworming wordt verdedigd door Rozmaryn voor zes complexen van rechtsregels die hij tot de "rule of law" rekent ${ }^{274}$. Evenals Constantinesco verwerpt Rozmaryn comparatieve begrippen die op voorhand en eigenmachtig gemeenschappelijke elementen selecteren uit verschillende rechtsstelsels. Rozmaryn laat het rechtsvergelijkende onderzoek beginnen met een opsomming van gemeenschappelijke elementen. Deze gemeenschappelijke elementen vormen een "internationale verzameling". Dit is een verzameling met elementen die tot verschillende rechtsstelsels behoren, bijwoorbeeld die van de 'rule of law'. Variabele details, bijvoorbeeld de contractsvrijheid, vallen buiten de internationale verzameling omdat deze verzameling volgens Rozmaryn uitsluitend identieke elementen omvat. De internationale verzameling is de doorsnede van twee of meer rechtsstelsels, want Rozmaryn ziet een rechtsstelsel als een verzameling elementen waarvan een deelverzameling kan samenvallen met elementen van een ander rechtssysteem. De elementen in de internationale verzameling zijn vergelijkbaar, de variabele details niet. De elementen in de internationale verzamelling zijn volgens Rozmaryn vergelijkbaar in het opzicht van 'rule of law' zonder op voorhand gebruik te maken van comparatieve begrippen.

Rozmaryn brengt een scheiding aan tussen vergelijkbare elementen enerzijds, en variabele details anderzijds: zijn internationale verzameling is homogeen. Niettemin beweert hij dat comparatieve begrippen tot op zekere hoogte worden toegepast binnen de nationale rechtsstelsels. Het gevolg daarvan noet zijn dat de extensie van het comparatieve begrip van Rozmaryn toch variabele elementen bevat ${ }^{275}$. Omdat het comparatieve begrip tot op zekere hoogte wordt toegepast, is de internationale verzameling heterogeen

273. Zie II. 11.

274. Zie II. 3.B.

275. Daarmee zou Rozmaryn de kritiek van Constantinesco (zie II. 3. B slot) kurnen wegnemen dat differentiërende elementen bij voorbat butten de wergelijking blijwen. 
en niet homogeen zoals Rozmaryn veronderstelt ${ }^{276}$. Het standpunt van Rozmaryn is inconsistent ${ }^{27}$. De extensionele begripsvorming van Rozmaryn werschaft geen eenduidige criteria om te bepalen welke objecten vergelijkbaar zijn omdat in het midden blijft welke nationale begripskenmerken als comparatieve begrippen toegepast worden. Eenzelfde internationale verzameling kan leiden tot deze of gene intensie van comparatieve begrippen ${ }^{278}$. Dé extensie van opgesomde elementen kan de intensie van een comparatief begrip zoals "rule of law" niet eenduidig vastleggen ${ }^{279}$. De intensie bepaalt de extensie $^{280}$, niet andersom. De opvatting van Rozmaryn moet worden verworpen.

Extensionele begripsvorming verschaft geen comparatief begrip, geen tertium comparationis. Extensionele begripsvorming levert geen begrippen die geschikt zijn voor hantering vanaf de beginfase. Extensionele begripsvorming woorkomt niet dat in de eindfase een vergelijkbaarheidsoordeel wordt weerlegd, zodat achteraf geconcludeerd moet worden dat vergeleken is wat onvergelijkbaar is. Comparatieve begrippen moeten eenduidig zijn om te voorkomen dat rechtsregels in de beginfase in een ander opzicht vergelijkbaar worden geacht dan in de eindfase ${ }^{281}$.

Het is niet aanvaardbaar dat de uitgangshypothese een ander comparatief begrip bevat dan het vergelijkbaarheidsoordeel dat uiteindelijk getoetst wordt met de gekozen rechtsvergelijkende methode. Deze overweging is van belang voor een welwillende interpretatie van de functionele benadering van Zweigert/Kötz ${ }^{282}$. Volgens Zweigert/Kötz moet het functiebegrip dat in de beginfase van het onderzoek tot een werkhypothese geleid

276. Rozmaryn zou de homogeniteit van zijn internationale verzameling slechts kurnen handhaven met de veronderstelling dat" de intensie van de begrippen in meer dan eén rechtsstelsel volledig samenvalt zodat uitsluitend identieke elementen tot hun extensie behoren: of. Herberger/Simon, 259. Maar dan kan Rozmaryn niet meer beweren dat comparatieve begrippen tot op zekere hoogte worden toegepast in de nationale rechtsstelsels. Als de intensie van nationale rechtsbegrippen niet volledig samenvalt, is de internationale verzameling wan Rozmaryn niet homogeen en vallen er variabele details binnen de extensite van zijn comparatiove begrip.

277. Rozmaryn zou zijn onderzoek natr de 'rule of law' kunnen beginnen net een typebegrip om dat te laten uitmonden in een soontbegrip, maar dat zou in strijd komen met zijn streven om niet op voorhand getbruik te maken van begrippen.

278. Ci, Pawlowiski, 55.

279. Cf. Brouwer, 51 .

280. Franken, 68; Loth 1991, 79; Sartori, 25, Op dit uitgang spunt is kritiek geleverd door Putnam: Douven, 144-145. Putnam levert geen overtuigend argument orn de betekenistheorie van Frege te verwerpen. Een begrip is zijn intensie ondat de intensie al zijn kenmerken omvat: Sartori, 40; cf. Franken, 69 noot 1; cf, Norreklit; 93.

281. Hieraan makkt Kokkini (II.\&4.B) zich schuldig war ze het functiebegrip in de betginfase opvat als "taak' en in de eindfase als "effect".

282. Zie II $\$ 3 . \mathrm{C}$. 
heeft, in de eindfase geverifieerd worden. Hun functiebegrip is echter meerduidig ${ }^{283}$ want het heeft zowel de betekenis van sociaal effect als die van juridische intentie: hun functiebegrip betreft enerzijds de feitelijke oplossing van een probleem ${ }_{\text {anderzijds de }}$ taak van rechtsregels dat probleem op te lossen. Daardoor bestaat het gevaar dat het vergelijkbaarheidsoordeel nu eens getoetst wordt aan sociale, dan weer aan juridische eigenschappen van de vergeleken rechtsregels. Dit gevaar ontbreekt indien strikt wordt vastgehouden aan het uitgangspunt van Zweigert/Kötz dat het functiebegrip een sociologisch tertium comparationis is dat buiten de vergeleken rechtsstelsels ligt. Dit is conform hun standpunt dat bij het opstellen van een werkhypothese in het begin van het onderzoek volledig wan het nationale begrippenstelsel geabstraheerd moet worden ${ }^{284}$. Dit impliceert dat een beginvraag als 'hoe beschermt het buitenlandse recht partijen tegen overhaasting?' slechts getoetst mag worden aan het sociale effect van rechtsregels. Een functiebegrip dat eenduidig is, laat hier geen onderscheid toe tussen rechtsregels die expliciet tegen overhaasting beogen te beschermen en rechtsregels die deze juridische intentie missen. Dienovereenkomstig wordt de volgende interpretatie van de functionele benadering aangehouden: het functiebegrip van Zweigert/Kötz heeft uitsluitend betrekking op het sociale effect waar het gaat om vergelijkbaarheid van rechtsregels.

\section{B. COMPARATIEVE BEGRIPPEN IN DE EINDFASE}

Het beschrijven van de vergeleken rechtsregels is aan de orde indien het vergelijkbaarheidsoordeel met een comparatief begrip is bevestigd. Als het vergelijkbaarheidsoordeel is bevestigd, is de intensie van het comparatieve begrip algemeen. Comparatieve begrippen bepalen dan het perspectief waarin de onderzochte rechtsregels vergelijkbaar zijn. De beschrijving met comparatieve begrippen in de eindfase ${ }^{285}$ moet berusten op een vergelijkbaarheidsoordeel. Er kan een internationale verzameling beschreven worden als thet vergelijkbaarheidsoordeel ${ }^{286}$ niet is weerlegd. Het comparatieve begrip is bruikbaar voor het beschrijven van een overeenkomstige eigenschap, bijvoorbeeld 'medeeigendom", in het geval van een internationale verzameling, hier: de regels van het Nederlandse en Duitse appartementsrecht ${ }^{287}$. Als het vergelijkbaarheidsoordeel is

283. Cf. Herberger/Simon, 261.

284. Van Reenen 1995, 187-188

285. De beschrijving van de inhoud wan rechrsregels kan owerigens hypothetisch zijn: Van Hoecke 191. Deze hypothese kan worden bevestigd met de bevestiging wan het vergelijkbaarheidsoordeel

286. Dit oordeel is voortopig: cf. Popper, 225.

287. Zie $11 . \S 1$. 
weerlegd, is de extensie van het comparatieve begrip empirisch leeg ${ }^{288}$ zodat beschrijving onmogelijk is omdat de vergelijkbaar geachte objecten de toegeschreven eigenschappen niet blijken te bezitten. Comparatieve begrippen zijn onbruikbaar voor het besehrijven van verschillen tussen rechtsregels. Verschillen tussen rechtsregels zijn variaties ${ }^{269}$ in de geobjectiveerde rechtsregels waarvoor de intensie van het comparatieve begrip geen criteria bevat. In die zin is het nut van comparatieve begrippen beperkt.

Het is de vraag onder welke voorwaarden comparatieve begrippen nuttig zijn voor de beschrijving van overeenkomsten of gelijkenissen ${ }^{290}$ tussen rechtsregels. Deze vraag zal worden beantwoord vanuit de kritiek van Constantinesco ${ }^{291}$ op het functiebegrip van Zweigert/Kötz. Het globale functiebegrip van Zweigert/Kötz gaat volgens hem voorbij aan de ontstaansgronden en de bestaansvoorwaarden, de juridische techniek waarmee een gemeenschappelijke rechtsinstelling zich realiseert en de rechtsgevolgen. Deze kritiek kan met een voorbeeld worden toegelicht. De Engelse 'mortgage' en de Franse 'hypothèque' vervullen grosso modo dezelfde functie ${ }^{292}$ : het verschaffen van zekerheid voor de betaling van een schuld ${ }^{293}$. Dit functiebegrip beschrijft geen overeenkomsten in juridische eigenschappen van de Engelse en Franse hypotheek omdat dit functiebegrip betrekking heeft op het sociale effect van rechtsregels ${ }^{294}$. Immanente begrippen zijn minder globaal dan het functiebegrip van Zweigert/Kötz omdat ze criteria zijn voor juridische eigenschappen zoals rechtsgevolgen. Met het immanente begrip 'adoptie' bijwoorbeeld kan de onderzoeker niet alleen de Engelse en Nederlandse 'sterke adoptie' vergelijken ${ }^{295}$, maar ook de Oostenrijkse rechtsregels met de rechtsgevolgen van "zwakke adoptie" ${ }^{296}$. Voor specifieke overeenkomsten tussen rechtsstelsels kunnen

288. Woor het empirische nut van begrippen in de rechtswergelijking geldt in beginsel dezelfde eis als voor de brukbatheid van begrippen in het algemeen, te weten dat de extensie niet empirisch leeg is: Tsouyopoulos, 161; ct. Sartori, 28, 51. Omdat nationale rechtsbegrippen met unieke kenmerken ook kumen beantwoorden an de eis dat de extensie niet enpirisch leeg is, moet deze algemene eis gespeciffued worden voor comparatieve begrippen. De extensie van een uniek rechtsbegrip is onvoldoende voor rechisvergelijkend onderzoek.

289. Doze wariaties zijn bijzondere eigenschappen van rechtsregels, geen overeenkomstige eigenschappen.

290. In het geval van een typebegrip: zie II. 1 .

291. Zie II. 3.C slot.

292. Cf. Schwab, 71.

293. Sarcevio, 284.

294. Zie III. 2. A slot.

295. Krause, 87, 90-91.

296. Krause, 90. 
twee verfijnde ${ }^{297}$ begrippen gevormd worden zoals het volgende voorbeeld ${ }^{298}$ laat zien. In twee rechtsstelsels bestaat er een verbintenis om uit de nalatenschap een geldbedrag aan bepaalde wettelijke erfgenamen te betalen, terwijl de erflater in drie andere rechtsstelsels niet onbeperkt mag beschikken over zijn nalatenschap. Voor immanente begrippen kan de opvatting van Engisch ${ }^{299}$ worden onderschreven dat comparatieve begrippen openstaan voor differentiaties en gebruikt kunnen worden ter concretisering van overeenkomsten tussen in aanmerking komende rechtsstelsels.

Het functiebegrip van Zweigert/Kötz voor sociale effecten van rechtsregels is onvoldoende specifiek voor het beschrijven van overeenkomsten in juridische eigenschappen van de vergeleken rechtsregels. Dit bezwaar geldt niet voor het functiebegrip van Drobnig ${ }^{300}$; de kritiek van Constantinesco is niet van toepassing op Drobnig zoals hierna aangetoond zal worden. Het functiebegrip van Drobnig is een typebegrip ${ }^{301}$ dat gelijkenissen in juridische oplossingen beschrijft. Het typebegrip van Drobnig betreft de juridische intentie ${ }^{302}$ van rechtsregels. Dit typebegrip omvat de typische oplossingen van bijvoorbeeld de trust, zowel de oplossingen in hoofdlijnen als de specifieke toepas singsgevallen die afzonderlijk worden beschreven. Dit typebegrip beoogt een beschrijving van het grote aantal ${ }^{303}$ en de grote diversiteit van verschijningsvormen en toepassingen van de trust ${ }^{304}$. Daaraan verbindt Drobnig de keuze van een representatief rechtsstetsell: een rechtsstelsel dat de typische oplossingen van de trust in zuivere vorm bevat. Het representatieve rechtsstelsel is het rechtsstelsel waarin de juridische oplossingen van bijvoorbeeld de trust bij uitstek aanwezig worden geacht. Dit representatieve rechtsstelsel bevat de trust als een exemplarisch object ${ }^{305}$ : een object dat de eigenschappen van de onderzochte objecten zo volmaakt mogelijk representeert ${ }^{306}$. Deze

297. Begripsverfjining inpliceer dat de algemene intensie van comparatieve begrippen wordt uitgebreid met additionele kenmerken. Er is echter een grens want begripsverfijining mag er niet toe leiden dat de vergelijkingsbasis verdwijnt onndat de internationale verzameling ontbreekt door de toegevoegde kenmerken: cf. Sartori, 68 noot 36. Als er slechts in éen rechtsstelsed een verbintenis zou bestaan om een geldbedrag aan wettelijke erfgentmen te betalen, terwijl de erflater in éćn ander rechtsstelsel niet onbeperkt mag beschikken ower zijn nalatenschap, kan het abstracte begrip niet worden verfijnd. De vergelijkingsbasis ontbreekt als slechts éerr rechtsstelsel blijkt te voldoen aan het verfijinde begrip.

298. Zie V.\& 4.A.

299. Zie II. \& 2.A.

300. Zie II. \& 2.A.

301. Zie II. 1: 'appartment ownership' als typebegrip.

302. Bartels, 77, 79: juridische functie; cf. Sarcevic, 287.

303. Fratcher, 3-5, onderscheidt 26 toepassingsmogelijkheden. Cf. Van Boeschoten 1994, 9-11.

304. Cf. Van Loon, 61 .

305. Cf. Esser, 368-369.

306. Cf. Engisch 1968, 245, 264; cf. Kuhlen 1977, 150. 
probleemoplossing is geintegreerd in het rechtsstelsel waartoe het behoort ${ }^{307}$. Deze probleemoplossing in het representatieve rechtsstelsel is beperkt tot hoofdlijnen, bijvoorbeeld het creëren van een afgezonderd vermogen in het geval van de trust ${ }^{308}$. De kenmerken van het functionele typebegrip zijn immanent aan het representatieve rechtsstelsel; die voor de specifieke toepassingsgevallen zijn immanent aan andere rechtsstelsels. Het typebegrip van Drobnig is een immanent begrip dat voldoende specifiek is voor de beschrijving ${ }^{30 \%}$ van gelijkenissen in juridische intenties.

Comparatieve begrippen die bruikbaar zijn voor het beschrijven van overeenkomsten tussen rechtsregels zijn nog niet geschikt woor het verklaren wan dogmatische verschillen tussen rechtsstelsels. Deze verklaring wordt nagestreefd door Mincke ${ }^{310}$. Mincke laat slechts beschrijvende begrippen toe als tertia comparationis. Voorbeelden van beschrijvende begrippen zijn: 'subjectief recht', 'objectief recht' en 'overeenkomst' ${ }^{11}$. Dit zijn zuiver gemeenschappelijke begrippen die door voortgaande vergelijkende analyse aangetroffen worden in bij voorkeur alle rechtsstelsels. Normatieve begrippen komen juist niet in aanmerking als tertia comparationis omdat ze gebonden zijn aan een rechtsstelsel. Mincke ziet een verschil tussen rechtsstelsels als een verschil in combinatiemogelijkheden van descriptieve begrippen. Deze combinatiemogelijkheden worden bepaald door het nationale begrippenstelsel. Dit kan worden toegelicht met het volgende verschil tussen het Duitse en Zwitserse rechtsstelsel dat door Mincke als voorbeeld wordt genoemd: anders dan her $Z$ witserse recht hanteert het Duitse recht een abstracte leer. Door deze abstracte leer is het Duitse verbintenissenrecht gescheiden van het goederenrecht, en kan 'koopovereenkomst' niet gecombineerd worden met 'eigendomsoverdracht'. Deze combinatiemogelijkheid ontbreekt niet in Zwitserland waar een rechtsgeldige titel is vereist voor de eigendomsoverdracht. Wanneer het Franse recht in de vergelijkende analyse wordt betrokken, blijkt het consensusbeginsel ongeschikt om de dogmatische verschillen van dit voorbeeld te verklaren. Daardoor kan Mincke niet bevestigen dat "overeenkomst' een beschrijvend begrip is. Voor de drie rechtsstelsels van zijn voorbeeld ontbreekt een tertium comparationis.

307. Cf. Esser, 349. Voor de beschrijving van het exemplarische object wordt niet volledig geabstraheerd wan het nationale begrippensielsel.

308. Van Boeschoten 1994, 5, 8, Van Loon, 51 .

309. Deze beschrijving kan niet bensten op een vergelijkbaarheidsoordeel met een functiebegrip voor sociale effecten. Drobnig is inconsequent waar hij een sociologisch tertium comporationis verkiest: zie II. $\$ 3, \mathrm{C}$.

310. Zie II: 4.A.

311. Het is overigens betwist dat het begrip "overeenkomst" identiek is voor her Engelse en het continentaalEuropese reclut: cf. Sanuel, 388-389; cf. Samuel/Rinkes, 75 . 
Mincke zoekt eigenlijk naar verklarende begrippen, niet naar beschrijvende begrippen zoals hij schrijft. Het streven naar verklaring dat de opvatting van Mincke bepaalt, leidt tot een vergaande beperking van het rechtsvergelijkende onderzoek. Verklaring van dogmatische verschillen is geen noodzakelijke fase in het rechtsvergelijkend onderzoek in tegenstelling tot beschrijving van geldende rechtsregels. Immanente begrippen die gedeeltelijk verschillend zijn, zijn voldoende voor het beschrijven van rechtsregels ${ }^{312}$. Voor het voorbeeld van Mincke kan "rechtsgeldige titel" als immanent begrip ${ }^{313}$ worden gekozen om een vergelijkbaar object te beschrijven. Het begrip 'rechtsgeldige titel' bevat naast gemeenschappelijke kenmerken nog bijzondere kenmerken die inherent zijn aan één van de begrippenstelsels. Deze bijzondere kenmerken betreffen de uiteenlopende sancties die de vergeleken rechtsstelsels verbinden aan het ontbreken van een rechtsgeldige titel ${ }^{314}$. De rechtsgevolgen van het ontbreken van een rechtsgeldige titel zijn verschillen ${ }^{315}$ waarvoor de intensie van het comparatieve begrip 'rechtsgeldige titel geen criteria bevat. Het begrip 'rechtsgeldige titel' kan correct toegepast worden op objecten met overeenkomstige eigenschappen. Voor de beschrijving van een internationale verzameling is het niet noodzakelijk dat de objecten van een comparatief begrip bijzondere eigenschappen missen.

\section{\$ 3. Toetsing van vergelijkbaarheidsoordelen}

\section{A. VERGELIIKBAARHEIDSOORDELEN MET FUNCTIEBEGRIPPEN}

Het functiebegrip is een sociologisch tertium comparationis ${ }^{316}$. Het functiebegrip van Zweigert/Kötz kan nuttig zijin in het geval van een sociaal probleem waarvoor juridische belangstelling bestaat zonder dat er sprake is van dogmatische probleemdefinities ${ }^{317}$. Het functiebegrip kan bovendien voorkomen dat het tot elkaar brengen van onderdelen

312. Mincke veronderstelt een tegenstelling tussen indiwiduele objecten enerajds, en dankzij negatiove abstractie wergelijkbare objecten anderzijds; of. Engisch 1968, 20, 24

313. Imnanerite begripsworming door middel van begripsvereenwoudiging: 2 ie $11 . \$ 3 . A$ :

314. Revindicatie in $Z$ witserland; actie wit ongerechtvaardigde verrijking in Duitsland: Meier, 61; Sauveplanne 1981,83. Het voert te ver om op de betreffende casuistiek in te gaan. Een woorbeeld met een conclusie als die van Mincke, is te vinden bij De Groot 1990a, 22; De Groot 1990b, 125: het Duitse beguip "Irrtum" is niet vergelijkbaar met het Franse begrip "erreur" of het Nederlandse "dwalling" omdat de betreffende rechtsgevolgen te zeer werschillen.

315. Door het verschil in rechtsgevolgen kunnen de rechtsbegrippen 'koopovereenkomst" en "eigendoms. overdracht" niet op dezelfde wijze gecontineerd worden.

316. Zie II. \$ 3.C en III. \$2.A slot.

317. Gessner, $133-134$. Een woorbeeld van een matschappelijk probleem dat in weel landen juridische belangstelling krijgt maar slechts in weinig landen gereguleerd is, is het gebnik van encryptic : een techniek ter beveiliging van her elektronische berichtenverkeer. 
uit rechtsorden wordt geforceerd, bijvoorbeeld adoptieregelingen en antitrustregelingen; het gaat hier om verschillende maatschappelijke behoeften ${ }^{318}$. De vraag is echter of een vergelijkbaarheidsoordeel met een functiebegrip, toetsbaar is. Deze vraag is van belang omdat er over het effect wan regelgeving in de verschillende landen weinig bekend is ${ }^{319}$ zodat er veelal geen gebruik gemaakt kan worden van resultaten van rechtssociologisch onderzoek.

Voor de toetsing van een vergelijkbaarheidsoordeel met een functiebegrip moet er worden gezocht naar specifieke rechtsregels voor gedragingen die op hun beurt leiden tot de oplossing van een sociaal probleem ${ }^{320}$. Het oorzakelijk verband tussen specifieke rechtsregels en het oplossen van een sociaal probleem is echter moeilijk vast te stel$\operatorname{len}^{321}$. Deze stelling zal worden toegelicht met een eigen voorbeeld. Stel: er is een specifieke regeling voor de besluitvorming in de gemeenschap van appartementseigenaars $^{322}$ voor woningnood ${ }^{323}$ als sociaal probleem. De vraag is dan welke sociale effecten deze besluitvormingsregels hebben op het lenigen van woningnood. Deze vraag is moeilijk te beantwoorden, zeker wanneer blijkt dat deze regels niet alleen positieve effecten hebben, maar ook leiden tot starheid in de besluitvorming ${ }^{324}$. Dergelijke negatieve effecten mogen niet buiten beschouwing blijven ${ }^{325}$ omdat ongewenste effecten tot de oplossing van een sociaal probleem behoren ${ }^{326}$. Met het sociologische tertium comparationis van Zweigert/Kötz kan geen onderscheid worden gemaakt tussen positieve en negatieve effecten. Bovendien kan daarmee niet worden uitgesloten dat het oplossen van woningnood dichterbij wordt gebracht door andere voorschriften dan die van

318. Kokkini 1988a, 131. Adoptieregels hebben betrekking op de institutie 'familie', antitustregels niet. Sociale instituties zoals 'familie' betreffen fundamentele problemen wan de maatschappij: Eisenstadt, $409-410$.

319. Eckhorf/Sundby, 214-215.

320. Cr. Griffiths, 8-9. Normconform gedrag is een middel ter bereiking van het doel dat de wetgever woor ogen stat: Rottleathuer, $113-11$ 年.

321. Cf. Griffiths, 10 .

322. Cf. Martens/van der Merwe, 276.

323. Cr. Mertens/van der Merwe, 275. Het sociale probleem is "woningnood" en niet bijvoorbeeld: het regelen van zeggenschap in woningcomplexen met meer rechthebbenden, ondat in het laatste geval niet volledig geabstraheerd zou worden van nationale rechtsbegrippen. Voor "woningnood' kan overigens de zwakkere formulering "behoefte aan woonruimte" gekozen worden.

324. Cf. Mertensivan der Merwe, 281. Starheid in de besluitvorming van appartementseigenaars kan het investeren in appartementsgebouwen doen afnemen.

325. Cf. Gessner, 138, 146: cf. Schmidt, 18.

326. Ook effecten die pas op lange termijn optreden, behoren tot de oplossing van een sociaal probleem. 
besluitvorming of zelfs door andere voorschriften dan die van het appartementsrecht ${ }^{327}$. Het functiebegrip omvat hier alle regels met een positief of negatief effect op woningnood zodat beperking tot specifieke regels met een positief effect moeilijik is. Daarom is een hypothese met een functiebegrip moeilijk te toetsen.

Waar de toetsbaarheid van een vergelijkbaarheidsoordeel ontbreekt, berust het functiebegrip op subjectieve vooronderstellingen ten aanzien van de werkelijkheid. Het functiebegrip is gebaseerd op een sociaal model, niet op rechtssociologisch onderzoek ${ }^{328}$. Dit model is geen afbeelding van de werkelijkheid maar een uitbeelding van de werkelijkheid ${ }^{329}$. Een model is een voorlopige ${ }^{330}$ objectivering van de werkelijkheid door middel van een inperking van die werkelijkheid ${ }^{331}$. Een model is een eenvoudiger voorstelling van zaken ${ }^{332}$ om het uiteindelijke object van onderzoek hanteerbaar te maken ${ }^{333}$. Een model maakt een chaotische veelheid van verschijnselen hanteerbaar door de onderzoeker een weg te wijzen ${ }^{334}$. Het functiebegrip biedt slechts een mogelijkheid tot oriëntatie op de sociale werkelijkheid ${ }^{335}$. Het functiebegrip heeft heuristisch in plaats van empirisch nut. Dit heuristische nut is wellicht voldoende voor een verkennend onderzoek naar een sociaal probleem waarvoor juridische belangstelling bestaat, of om te voorkomen dat het tot elkaar brengen van onderdelen uit rechtsorden wordt geforceerd. Het functiebegrip van Zweigert/Kötz heeft echter geen empirisch nut voor de rechtsvergelijking tenzij het vergelijkbaarheidsoordeel in uitzonderlijke gevallen getoetst kan worden.

De kritiek van Constantinesco ${ }^{336}$ op de functionele begripsvorming is terecht. Zijn kritiek bestaat uit twee samenhangende punten: Zweigert/Kötz reduceren de diversiteit van juridische oplossingen en rechtsproblemen; zij postuleren ten onrechte universaliteit

327. Er wordt inmers bij het opstellen van een werkhypothese in het begin van het onderzoek volledig geabstraheerd van het nationale begrippenstelsel: zie $11.83 . \mathrm{C}$ en III. 2.A. Eenbeperking tot regels van appartementsrecht, laat staan tot specifieke regels wan besluitworming, is onmogeljik als $Z$ weigert/Kötz consequent zijn. In een vervolgfase van het onderzoek komt niettenin de juridische dogmatiek in beeld, maar met het functiebegrip kan dan nauwelijks een rechtsgebied of specifieke rechtsregel geselecteerd worden.

328. Cf. Van Reenen 1995, 184, 190.

329. Cf. Van Peursen, 211, 218-219.

330. Van Peursen, 209, 219-220.

331. Cf. Van Peursen, 217, 219.

332. Bertels/Nauta, 159; cf. Sartori, 79.

333. Cf. Bertels/Nauta, 156.

334. Cf. Van Peursen, 214-215.

335. Gessner, 136; of. Gessner, 144-145.

336. Zie II. \& 3.C slot. 
voor hun functiebegrip. Het eerste punt van kritiek is een verwijt van vereenvoudiging dat strookt met bovenstaande constatering dat Zweigert/Kötz een model hanteren. Met Constantinesco kan daaraan het volgende worden toegevoegd: Zweigert/Kötz postuleren weliswaar dat elke ontwikkelde samenleving haar rechtsstelsel een identiek probleem tot taak stelt omdat de sociale behoeften dezelfde zouden zijn, maar het is onduidelijk wat onder sociale behoeften verstaan moet worden ${ }^{337}$. Daardoor staat niet vast welke sociale behoefte tot welk sociaal probleem leidt, lat staan welk sociaal probleem door het recht opgelost moet worden. Het is van de regelgever afhankelijk of een sociaal probleem wordt erkend als een rechtsprobleem: normatieve ${ }^{338}$ of ideologische ${ }^{339}$ overwegingen spelen een rol bij de definiëring wan een sociaal probleem als een door het recht op te lossen probleem. Dit alles wordt niet onderkend. Zweigert/Kötz maken geen principteel onderscheid tussen sociale problemen en rechtsproblemen ${ }^{340}$. Ook het tweede punt van kritiek van Constantinesco is juist: de vermeende ${ }^{34 i}$ universaliteit van het functiebegrip berust op subjectieve vooronderstellingen ten aanzien van rechtsinstellingen ${ }^{342}$. De kritiek van Constantinesco is van toepassing op Zweigert/Kötz, maar niet op Drobnig: een welwillende interpretatie van het standpunt van laatstgenoemde leidt ertoe dat Drobnig een immanent begrip uitwerkt ${ }^{3+3}$.

\section{B. VERGELUKBAARHEIDSOORDELEN MET IMMANENTE BEGRIPPEN}

Immanente begripsvorming vindt plaats door begripsvereenvoudiging ${ }^{344}$ en levert een kenmerk waarvan verondersteld wordt dat het gemeenschappelijk is aan meer rechtsstel-

337. Huppes, 192

338. Het verschaffen van rechtswaarborgen mag niet ondergeschikt zijn an de sociale werkelijkheid: cff Lecheler. 2275-2277.

339. Hill, 108.

340. Een witvloeisel daarvan is dat thet aanvankelijk te onderzoeken probleem zoveel mogelijk in de omgangstal omschreven wordt.

341. Universaliteit is niet vereist voor comparatieve begrippen. De toetsing wan een vergelijkbaarheidsoordeel kan beperkt worden tot een gering anttal rechtsstelsels. Het is niet noodzakelijk dat een vergelijkbaarheidsoordeel voor alle rechtsstelsels geldt. Dit neemt niet weg dat universaliteit bij wijze van hypothese opgenomen kan worden in een vergelijkbaarheidsoordeel, bijvoorbeeld als volgt: voor alle rechtsstelsels geldt dat zij regels wan nationaliteitsrecht bevatten : of. De Groot 1988b, 3. Dan is sprake wan een postulat van empirische universaliteit: of. Engisch 1958, 64. Deze hypothese kan op enig moment weentegd worden want een universeel oondeel kan niet worden afgeleid uit een eindige hoeveetheid hypothetische warnemingsuitspraken: ef. Popper, 34-35, 54 noot 1. Cf. De Vries, 55-56: een sanenvatting van het standpunt van Popper.

342. Hill, 104 .

343. Zie II. $\$ 2 . A$ en III. $\$ 2 . B$.

344. Zie II.8. 3.A. 
sels. Nadat een gemeenschappelijk begripskenmerk is gevormd, moet het vergelijkbaarheidsoordeel getoetst kunnen worden aan eigenschappen van de vergeleken rechtsregels. Deze eigenschappen worden mede bepaald door de vergeleken begrippenstelsels. Daarom impliceert de toetsbaarheid van vergelijkbaarheidsoordelen met immanente begrippen het volgende: er moeten begripskenmerken gelokaliseerd kunnen worden in verschillende begrippenstelsels; er moet binnen deze begrippenstelsels een interpretatie kunnen plaatsvinden die niet wordt overheerst door het nationale begrippenstelsel waarmee de onderzoeker het meest vertrouwd is ${ }^{345}$. Als aan deze voorwaarden niet voldaan kan worden, heeft het immanente begrip geen empirisch nut. Het vergelijkbaarheidsoordeel met een immanent begrip is weerlegd indien slechts één rechtsstelsel blijkt te voldoen aan dit begrip. Een vergelijkbaarheidsoordeel met immanente begrippen is bevestigd indien de juridische intentie ${ }^{346}$ van de vergeleken regels dezelfde is. Het immanente begrip heeft empirisch nut indien de interpretatie van de vergeleken begrippenstelsels laat zien dat voor deze intentie een gemeenschappelijk kenmerk aanwezig is.

Het lokaliseren van begripskenmerken in verschillende begrippenstelsels is problematisch. Dit is het gemakkelijkst wanneer deze begripskenmerken zich op dezelfde systeemplaats bevinden ${ }^{347}$. Het is echter niet vanzelfsprekend dat de gezochte begripskenmerken op een overeenkomstige plaats te vinden zijn. Zweigert/Kötz waarschuwen terecht dat de onderzoeker moet vermijden slechts op die systeemplaats te zoeken die correspondeert met zijn eigen begrippenstelsel ${ }^{348}$. Zo worden regels met overeenkomstige eigenschappen in het ene rechtsstelsel binnen het bewijsrecht ingedeeld en in het

345. Cf. Koopmans, 6-7.

346. Cf. Alchourrón/Bulygin, 68: oplossing voor een groep gevallen. $\mathrm{Cr}$. Wank, 112 doel van de reggelgeving.

347. Overeenkomstige systeemplaatsen doen zich voor bij de receptie van een wetboek in een ander rechtsstelsel. Bij thet ontwerpen van codificaties wordt weelal rekening gehouden met exenplarische wetboe. ken: cf. De Groot 1987, 20-21. Een rechtsstelsel kan echter meer wetboeken en wethen onvatten.

348: Zie II. \& 3.C. Overigens is het nationale begrippenstelsel geen absolutut gegeven. Dit blijkt uit de indeling in traditionele rechtsgebieden enerzijds en functionele rechtsgebieden anderzijds. De toerekening van rechtsregels tot traditionele dan wel functionele rechtsgebieden brengt een ander normdoel met zich: Van Laer 1990, 100-101. De ordening naar normdoel is immanent: Van Laer 1990, 105. De periferie van functionele rechrsgebieden kan corresponderen met het nomdoel van traditionele rechtsgebieden: Van Laer 1990, 106. Dan is polyhiërarchie mogelijk. Deze polyhierarchie kan worden verzacht door een optimale, dominante systemplaats: ef. Engisch 1957, 187. Zo heeft "huwelijkssluiting 'geen dominante plaats in het nationaliteitsrecht. Daarentegen heeft de 'optiewerklaring" in hoofdzaak rechtsgewolgen binnen het nationaliteitsrecht: of. De Groot $1988 \mathrm{~b}, 216$. 
andere rechtsstelsel als vormvoorschriften beschouwd ${ }^{349}$, Bij een afwijkende indeling in rechtsgebieden corresponderen de systeemplaatsen van de vergeleken begrippenstelsels niet, waardoor het lokaliseren van een immanent begrip bemoeilijkt wordt. Het is bovendien niet noodzakelijk dat de vergeleken begrippenstelsels evenveel systeemplaatsen hebben één van de vergeleken begrippenstelsels kan meer gedifferentieerd zijn $^{\text {}}{ }^{\text {s0 }}$. Als het buitenlandse begrippenstelsel niet evenveel systeemplaatsen ${ }^{351}$ heeft, is dit geen yolledige afspiegeling ${ }^{352}$ van het eigen begrippenstelsel. Dan heeft het buitenlandse begrippenstelsel een andere samenhang waardoor het lokaliseren van in aanmerking komende systeemplaatsen wordt bemoeilijkt. In het meest ongunstige ge$\mathrm{val}^{353}$ is het onderzoeken van alle systeemplaatsen van het buitenlandse begrippenstelsel nodig. Dit maakt het lokaliseren van begripskenmerken niet volstrekt onmogelijk. Toch is het vergelijkbaarheidsoordeel niet tøetsbaar als het buitenlandse begrippenstelsel een totaal afwijkende samenhang heeft, want dan zal een interpretatie plaatsvinden die wordt overheerst doot het eigen begrippenstelsel.

Op het lokaliseren van kenmerken in uiteenlopende begrippenstelsels kan de weerlegging van een vergelijkbaarheidsoordeel met een immanent begrip volgen. In onderstaand voorbeeld ${ }^{354}$ ontbreekt een immanent begrip omdat het Engelse en het Franse goederenrecht geen uniforme structuur bezitten. Deze begrippenstelsels staan niet toe dat er een gemeenschappelijke betekenis voor een immanent begrip vastgesteld wordt. De 'real mortgage' in het Engelse rechtsstelsel en de 'hypothèque' in het Franse rechtssysteem vallen onder het bovengeschikte rechtsgebied 'real property" respectievelijk 'biens immeubles'. Aan de Engelse onderscheiding tussen 'personal property' en 'real property' ligt een ander criterium ten grondslag dan aan de Franse onderscheiding tussen

349. Cf. David 1992, 12. Een ander voorbeeld wordt genoemd door De Groot 1989, 5: problement die in het ene land wia het privatrecht worden opgelost, worden in het andere land opgelost via het besruursrecht of het strafrecht. Door zogeheten 'schakelbepalingen' in een rechtsstelsel kan de grens tussen privaatrecht tur bestuurstecht vervagen of. Samuel/Rinkes, 94.

3.50. Zo kent Duitsland een meer gedetailleerde en uitvoerige wettelijke regeling wan het overheidstoeziclit op iming sorganisaties in het auteursrecht, wergeleken met de toezichtsregeling in Nederland. Cf. Dahberg $₫ 981 \mathrm{~b}, 87$ : eem meer gedifferentieend systeem is slechts gedeeltelijk verenigbar met het grovere systeen.

351. Of evenveel systeemplaatsen met een afwijkende samenhang.

352. Cr. Klug, 87 . Klug beweert dat het isomorfiebegrip voor elke rechtsvergelijking relevant is omdat het de taak van de rechtsvergelijking is om isomorfie op te sporen.

353. Een grensgeval is dat slechts eén systeemplaats correspondeert zodat de omgewing daarvan total verschilt ten opzichte wan het eigen begrippenstelsel. Er is geen garantie dat de vergelleken rechtsstelsels geen radical verschillende begrippenstelsels zijn: of. Douven, 155 .

354. Sarcevic, 284-286. 
"biens meubles" en "biens immeubles" 355 : het Engelse criterium betreft de procedure, het Franse criterium betreft de inhoud ${ }^{356}$. Daarom is het rechtsgebied 'real property' niet identiek aan 'biens immeubles'. Omdat een gemeenschappelijk kenmerk op een hoger niveau ontbreekt, is het ondergeschikte 'real mortgage' niet identiek aan 'hypothèque'. Bovendien kent het Franse recht geen onderverdeling van 'personal property' in 'chattels real' en 'chattels personal'. Daardoor kan er evenmin een gemeenschappelijk kenmerk worden geselecteerd voor de Engelse "chattel mortgage" enerzijds, en de Franse hypotheekvorm 'hypothèque mobilière' anderzijds ${ }^{357}$. De hierrarchische relaties binnen het ene rechtsstelsel verschillen van de hierrarchische relaties binnen het andere rechtsstelsel. Een immanent begrip met empirisch nut ontbreekt op hogere en lagere niveaus.

De toetsbaarheid van een vergelijkbaarheidsoordeel met immanente begrippen bestaat uit de mogelijkheid om een gemeenschappelijke intentie vast te stellen. Deze intentie wordt mede bepaald door de begrippenstelsels waartoe de juridische oplossing behoort. Dit geldt niet alleen voor soortbegrippen, maar ook voor typebegrippen zoals dat van Drobnig voor de trust ${ }^{358}$. Immanente typebegrippen hebben empirisch nut indien zij gemeenschappelijke begripskenmerken voor een juridische intentie blijken te bezitten.

\section{$\S 4$. Presentatie van onderzoeksresultaten}

\section{A. RECHTSVERGELIJENDE CLASSIFICATIESYSTEMEN}

De presentatie van onderzoeksresultaten is een noodzakelijke fase in het rechtsvergelijkend onderzoek omdat nieuw onderzoek aan voltooid onderzoek gerelateerd moet kunnen worden ${ }^{359}$. Voltooid onderzoek is in elk geval een beschrijving van overeenkomsten tussen rechtsstelsels. Voltooid onderzoek beschrijft een internationale verzameling, bijvoorbeeld de regels van het Nederlandse en Duitse appartementsrecht ${ }^{360}$. Daarom

355. David 1980, 35.

356. Cf. Bell, 19 .

357. Cf. Sarcewic, 285, 286, 289; of. Sauveplanne 1974, 299: anders dan het Franse recht heeft het Engelse recht de "chattel mortgage' geaccepteerd.

358. Zie III. $2 . B$.

359. Zie III. 1. Nieuw onderzoek behoeft owerigens niet tot kenniswermeerdering te leiden, want in nieuw onderzoek kan een eerder vergelijkbaarhe id soordeel weerlegd worden. Bovendien kan het relateren van nieuw onderzoek aan voltooid onderzoek miet alleen bijdragen aan kennisverineerdering, maar ook akn de verbetering wan de nationale wetgeving. Specifiek gebruik van rechtswergelijking blifft hise buiten beschouwing: zie hoofdstuk I.

360. Zie III. \& 2.B. 
geldt niet alleen voor deze beschrijving, maar ook voor de presentatie van onderzoeksresultaten de noodzakelijke voorwaarde dat het vergelijkbaarheidsoordeel niet is weerlegd.

De presentatie van onderzoeksresultaten kan geschieden met een "rechtsvergelijkend classificatiesysteem': een systematisch geheel van comparatieve begrippen ${ }^{36}$. Dit zijn de volgende classificatiesystemen van het vorige hoofdstuk ${ }^{362}$ : thet absoluut-autonome systeem van Zweigert/Kötz en het relatief-autonome systeem van Drobnig. Het classificatiesysteem van Zweigert/Kötz bevat functiebegrippen voor het sociale effect van rechtsregels ${ }^{363}$, dat van Drobnig bevat immanente begrippen voor de juridische intentie van rechtsregels ${ }^{364}$. Comparatieve begrippen zijn volgens $Z$ weigert/Kötz en Drobnig noodzakelijk als bouwstenen van rechtsvergelijkende classificatiesystemen. Zij zijn bovendien van mening dat de indeling van rechtsvergelijkende classificatiesystemen niet a priori maar door vergelijkend onderzoek tot stand komt. Dit leidt tot de vraag of comparatieve begrippen voldoende zijn voor een zodanige indeling van een rechtsvergelijkend classificatiesysteem dat misverstanden omtrent voltooid onderzoek worden voorkomen.

Een comparatief begrip beschrijft een overeenkomstige eigenschap, geen verschil tussen het Nederlandse en Duitse appartementsrecht ${ }^{365}$. In een rechtsvergelijkend classificatiesysteem heeft het comparatieve begrip 'hypotheek' geen betrekking op een verschil tussen rechtsstelsels. Toch is een comparatief begrip onvoldoende om dit misverstand te voorkomen. Een rechtsvergelijkend classificatiesysteem moet hiërarchische relaties bevatten voor een juiste interpretatie van het comparatieve begrip als rechtsgebieden een verschillende structuur hebben ${ }^{366}$. Dit blijkt uit het relatief-autonome systeem van

361. Dahiberg 1974, 27: gen classificatiesystem is een geheel var begrippen. Dobrowolski, 247: classificeren impliceert systematiseren.

362. Zie II. \&2. A. Het is onduidelijk of het niet-autonome systeem watn Constantinesco comparatiewe begrippen bevat, mede omdat Constantinesco een conceptueel tertum comparationis verwerpt. Bovendien gat atan het systeem van Constantinesco een atgemeen rechtsbegrip wooraf: Constantinesco 1981, 184; of. Constantinesco 1981, 178, 183 noot 31, 190. De definitie ervan zou neutraal moeten zijn woor her recht van moderne, traditionele of primitieve samenlevingen. Met het algemene rechtsbegrip wan Constantinesco zou dle vergelijking wan rechtsstelsels onderscheiden kunnen worden van de vergelijking van bijwoorbeeld politieke systemen. Dit algemene rechtsbegrip schiet eelater zijn doel voorbij ondat het niet beperkt is tot juridische regels: Van Reenen 1995, 197-198. Het systeem van Constantinesco komt niet in aanmerking als een rechtsve rgelijkend classificatiesysteem.

363. Zie I., 3.C, MII, 2.A en HII 3.A.

364. Zie III.\$2.B.

365. Zie II. \$ 1 en III. \& 2.B.

366. Zie III. \$ 3.B over het werschil in stnucturur tussen het Engelse en Franse goederenrecht in verband met het voorbeeld van de hypotheek. 
Drobnig. Drobnig is zich ervan bewust dat de trust moet worden begrepen tegen de achtergrond van het Anglo-Amerikaanse goederenrecht met een andere structuur dan het continentale goederenrecht ${ }^{367}$. Drobnig behandelt de hoofdzaken van de trust binnen een Anglo-Amerikaans kader; het continentale classificatiesysteem wordt niet toegepast op deze beschrijving. Drobnig is echter inconsequent door de keuze van het continentale classificatiesysteem voor de trust, als specifieke toepassingsgevallen naar Anglo-Amerikaans recht beschreven worden. Omdat deze toepassingsgevallen bij hun continentale tegenhangers zijn ingedeeld, worden er overeenkomsten gesuggereerd waar verschillen tussen rechtsfamilies zijn geconstateerd. Drobnigs inconsistentie kan leiden tot misverstanden omtrent voltooid onderzoek.

Constantinesco ${ }^{36 \%}$ beweert dat Drobnigs relatief-attonome systematiek de typische oplossingen losmaakt van de specifieke structuur van hun rechtsstelsel. Deze kritiek op Drobnig is misplaatst: deze kritiek is van toepassing op het absoluut-autonome classificatiesysteem van Zweigert/Kötz waarmee gestreefd wordt maar een bevrijding van de nationale systematiek. Het systeem van Zweigert/Kötz bevat sociale problemen met een samenhang die niet door de indeling van rechtsstelsels wordt bepaald ${ }^{369}$. Daar staat tegenover dat Zweigert/Kötz vermijden een rechtsfamilie te prefereren, terwij] Drobnig voor de 'International Encyclopedia of Comparative Law' de voorkeur geeft aan het continentale classificatiesysteem. Drobnigs voorkeur is subjectief. Ook de keuze van een Anglo-Amerikaans kader als uitzondering voor de trust is subjectief ${ }^{370}$. Deze keuze berust op een waardering van het rechtsstelsel dat als representatief is aangemerkt, een waardering die achterwege zou moeten blijven bij de indeling van rechtsstelsels in rechtsfamilies ${ }^{37 !}$.

De kritiek van Constantinesco is voorts gericht op het continentale classificatiesysteem van Drobnig ${ }^{372}$, dat in beginsel voor de hele "International Encyclopedia of Comparative Law' moet gelden. Volgens Constantinesco moet een rechtsvergelijkend classificatiesysteem rekening houden met fundamentele verschillen tussen rechtsfamilies. Dit impliceert dat een rechtsvergelijkend classificatiesysteem misverstanden omtrent de ver-

367. Cf. Van Boeschoten 1994, 6, 8; cf. Lipstein, $4,17$.

368. Zie III. 2.A.

369. Cf. Canaris, 30 .

370. Cf. Hill, 106.

371. Cf. De Groot/Schneider, 57-58.

372. Ook Kokkini heeft har rechtsvergelijkende classificatiesysteem beperkt tot eên rechtsfamilie: zie II. \$ 4.B. 
gelijkbaarheid van complete rechtsstelsels ${ }^{373}$ zou moeten voorkomen ${ }^{374}$. Aan dit vereiste kunnen comparatieve begrippen niet voldoen want comparatieve begrippen hebben betrekking op afzonderlijke rechtsregels ${ }^{375}$, niet op complete rechtsstelsels. $\mathrm{E} r$ is hier sprake van een verschil in schaal of niveau ${ }^{376}$. Een comparatief begrip bevat geen deugdelijk criterium ${ }^{37}$ om vergelijkbare rechtsstelsels in rechtsfamilies af te bakenen. Dit neemt niet weg dat woltooid onderzoek kan bijdragen aan het ontdekken van grenzen van rechtsfamilies, zoals Engisch ${ }^{378}$ terecht heeft opgemerkt. Voltooid onderzoek trekt grenzen van vèrgelijkbaarheid: de Franse en Engelse hypotheekvormen zijn bijwoorbeeld niet vergelijkbaar ${ }^{379}$. Het is echter niet denkbeeldig dat grenzen van vergelijkbaarheid voor bijvoorbeeld 'adoptie', 'huwelijk' en 'wettelijk erfdeel', telkens andere rechtsstelsels omvatten zodat de groepering van deze rechtsstelsels een sterk wisselend beeld laat zien. Comparatieve begrippen zijn onvoldoende voor een indeling van rechtsstelsels in rechtsfamilies ten behoeve van een rechtsvergelijkend classificatiesysteem.

\section{B. EENDUIDIGE TERMINOLOGIE}

Omdat comparatieve begrippen eenduidig moeten zijn ${ }^{380}$, zijn ze in beginsel geschikt voor de ontwikkeling van een eenduidige terminologie ${ }^{381}$ voor de rechtsvergelijking. Het is echter de vraag of comparatieve begrippen voldoende zijn om misverstanden omtrent voltooid onderzoek te voorkomen. Misverstanden zijn uitgesloten indien comparatieve begrippen zuiver gemeenschappelijk zijn zodat ze door synoniemen weergegeven

373. Kokkini 1988b, 232: macrovergelijking.

374. Cr. De Boer 1994, 307-308. Een rechtsfamilie biedt niet meer dan een allereerste orièntatie omtrent al dan aiet getijksoortige rechtssteisels: De Groot 1988a, 10, 13, 16; cf. Kokkini 1988a, 78, 87, 179; cf. Van Reenen 1996, 82.

375. Kokkini 1988a, 131; Kokkini 1988b, 233: microvergelijking.

376. Constantinesco 19726, 211; Constantinesco 1983; 161 .

377. Bijwoonbeeld een criterium woor de hierarchische relaties binnen een rechtsgebied zoals het goederenrech. De indeling van conplete rechtsstelsels in een rechtsfamilie kan echter niet worden gebaseerd op én rechtsgebied. De groepering van rechtsstelsels in rechtsfamilies kan onder meer berusten op de conceptuele struciuur van complete rechtsstelsels: of. David 1992, 15: cf. Van Reenen 1996, 78. Bovendien is ten comparatief begrip geen exclusief criterium om vergelijkbare rechtsstelsels in rechtsfamilies af te bakenen, ondat de groepering wan complexe rechtsstelsels meer dan eén criterium vereist: cf. Van Reenen 1996, 93.

378. Zie III.82.A.

379. Zie III.8 3.B.

380. Zie III. 2.A.

381. Een eendudige terminologie dient het ideaal van wetenschappelijke communicatie: of. Baumann, 85 ; of. Engelien, $59 ;$ of. Gadamer, 410 . 
worden. Dit grensgeval doet zich voor bij elementaire rechtstermen met een absoluut identieke betekenis ${ }^{382}$. Elementaire rechtstermen zijn synoniemen die hetzelfde begrip aanduiden ook al worden deze termen uitgedrukt in werschillende talen ${ }^{383}$. Synoniemen zijn slechts bij hoge uitzondering beschikbaar voor de representatie van comparatieve begrippen ${ }^{384}$. Alleen dan zijn comparatieve begrippen voldoende voor een eenduidige terminologie.

Het maken van afspraken is nodig als synoniemen ontbreken omdat het comparatieve begrip niet zuiver gemeenschappelijk is. Dit zal met het volgende voorbeeld worden toegelicht: de nationale rechtsterm 'réservataire' betreft Franse rechtsregels ${ }^{385}$, 'Noterbe' heeft betrekking op Oostenrijkse rechtsregels ${ }^{386}$. Dit verschil ligt besloten in de bijzondere intensie van deze nationale rechtsbegrippen. De intensie ${ }^{387}$ van een immanent begrip is niet van toepassing op de verschillende rechtsgevolgen ${ }^{388}$ : in Frankrijk heeft de "réservataire" recht op een fractie van de nagelaten goederen, in Oostenrijk heeft de 'Noterbe' slechts recht op een fractie van de geldwaarde daarvan ${ }^{389}$. De Franse en Oostenrijkse rechtsstelsels verbinden geen internationale betekenis aan de rechtstermen 'réservataire' en 'Noterbe'. Daartoe is een afspraak nodig. Dat geldt meestal ook voor nationale rechtstermen die door hun veelvuldig gebruik in meer dan één rechtsstelsel een algemene bekendheid genieten ${ }^{300}$ zoals 'eigendom', 'contract', 'huwelijk' en 'hypotheek' ${ }^{39 !}$. Bekendheid maakt termen niet tot synoniemen.

382. Niet zozeer 'recht' en 'rechtvaardigheid' die Constantinesco (II. $\$ 4$. B) tot een rechtsfamillie beperkt acht, maar wellicht "subjectief recht", "objectief recht' en 'overeenkomst' die Mincke (II.\& 4.A) noemt.

383. Cf. Franken, 69; cf. Loth 1991, 76; cf. Sartori, 84.

384. Mincke (zie II. 4.A) betwist dat bestaande rechtsternen geschikt zijn voor de weergave van begrippen die niet zuiver gemeenschappelijk zijn, zoals "huwelijk". Volgens Mincke verwijzen dergelijke rechts termen naar rechtsregels die in het ene, maar niet in het andere rechtsstelsel van toepassing zijn. Ondat deze regels miet identiek zijn, is een perfecte vertaling van nationale rechsstermen zijns inziens onmogelijk. Deze constateringen zijn weliswaar juist, maar geen argument tegen de mededeelbatheid wan gedeeltelijk verschillende begrippen. Buitenlandse rechtstermen zijn ook mededeelbatr als absolute begripsidentiteit ontbreekt: De Groot/Rayar, 526; cf. Kisch, 209

385. Art. 913 e.v. Code Civit.

386. Par. 784 e.ฬ. Allgemeines Bürgerliches Gesetzbuch.

387. Er is een gemeenschappelijke juridische intentie omdat zowel thet recht op een firactie van de nagelaten goederen als het recht op de geldwaarde daarvan, in het leven zijn geroepen ter bescherming wan verwanten tegen onterving door de erflater: cf. Mellema, 142.

388. Zie III.\& 2.B.

389. Zie V.\$ 4.A.

390. Cf. Meijers 1948, 24.

391. David 1992, 273; cf. Drobnig 1972, 126. 
Indien de vergeleken rechtsstelsels een bijzondere betekenis toekennen aan hun rechtstermen, is er geen sprake van synoniemen maar van meerduidige ${ }^{392}$ rechtstermen met een gemeenschappelijke betekenis naast een bijzondere betekenis. In dat geval representeert eenzelfde term zowel de intensie van een comparatief begrip als de intensie van een national rechtsbegrip ${ }^{399}$. Dan duidt dezelfde term verschillende begrippen aan ${ }^{354}$. Een nationale term die nu eens de algemene intensie van een comparatief begrip, dan weer tevens de bijzondere intensie van een nationaal rechtsbegrip uitdrukt, is niet eenduidig. Drobnig ${ }^{395}$ noemt in dit verband: 'guter Glaube' als voorbeeld. Deze term is weliswaar letterlijk identiek voor verschillende Duitstalige rechtsstelsels, maar niettemin meerduidig. Om verwarring te voorkomen verlangt Drobnig terecht dat de nationale betekenis wordt onderscheiden van de algemeen vergelijkende betekenis die daaraan wordt toegevoegd. Daartoe moet een afspraak worden gemaakt. Dergelijke afspraken zijn niet bindend omdat er geen autoriteit ${ }^{396}$ is om naleving af te dwingen. Afspraken voor de introductie van een term voor een comparatief begrip zijn slechts geldig voor degenen die deze afspraken onderschrijven ${ }^{39}$.

Een term voor gedeeltelijk werschillende comparatieve begrippen moet trefzeker zijn om de aanvaarding van afspraken omtrent een eenduidige terminologie te bevorderen ${ }^{398}$. De keuze van een term moet duidelijk maken dat slechts een algemeen vergelijkende betekenis wordt weergegeven. Daarom verdient het aanbeveling dat zo min mogelijk wordt aangesloten bij meerduidige rechtstermen in gebruik bij de vergeleken rechtsstelsels ${ }^{399}$. Tegelijkertijd moeten termen voor comparatieve begrippen herkenbaar zijn als termen met een juridische betekenis ${ }^{400}$. Het voldoen aan beide vereisten is mogelijk door het gebruik van nummers die telkens refereren aan van nationale rechtssyste-

392. Het gat hier niet om meerduidigheid binnen hetzelfde, bijvoorbeed Franse, rechtsstelsel zoals in het gevall van 'adoption". Deze nationate term staat voor "adoption plèrière' of 'adoption simple': cf. Krause, 87,90.

393. Cf. Herberger/Simon, 261.

394. Cf. Franken, 69.

395. Zie II. \& 4 sub (b).

396. Cf. Sacco. 29.

397. Nationale rechtstalen blijven onmisbaar voor de introductie wan een internationale betekenis voor een comparatiof begrip: cf: Vitu den Bergh, 36; cf. Gadamer, 422; of. Van Laer 1977, 384. De afgesproken betekenis is intersubjectief: tef. Norreklit; $69,101_{\text {, }} 114$.

398. Cf. Dahlloerg 1974, 111 .

399. Santori, 50: 'different things should have different aames'. Hier wordt het standpunt van Constantinesco die vrijwel onwoorwaardelijk de voorkeur geeft aan nationale rechtstermen (II. \$ 4. B slot) werworpen.

400. Cf. Baumainn, 89 . 
men geabstraheerde juridische categorieën ${ }^{40 !}$ indien de toekenning van deze nummers geschiedt overeenkomstig een rechtswergelijkend classificatiesysteem ${ }^{402}$. De vervulling van deze voorwaarde is van belang omdat nummers die onathankelijk zijn wan een rechtsvergelijkend classificatiesysteem, geen algemeen juridische betekenis hebben. Overigens zijn termen uit een omgangstaal, die Zweigert/Kötz ${ }^{403}$ verkiezen voor het formuleren van de werkhypothese in de beginfase van het onderzoek, ongeschikt. Omschrijvingen zoals "Beschränkungen des Erblassers bei Verfügungen von Todes wegen zugunsten bestimmter Personen (z.B. Ehegatten) ${ }^{404}$ hebben nauwelijks juridische betekenis. Omgangstaal is onvoldoende precies voor een eenduidige terminologie $^{405}$.

De wraag is vervolgens of nieuwe termen ${ }^{406}$ geformuleerd kunnen worden die eenduidig zijn en als rechtstermen herkenbaar. Als dat mogelijk is, is er een alternatief voor het gebruik van nummers van een rechtsvergelijkend classificatiesysteem. Naar dit alternatief is gezocht door Drobnig voor gevallen waarin het Engels geen vertaling bevat voor de vergeleken rechtstermen. Drobnig ${ }^{407}$ noemt twee gevallen waarin nieuwe Engelstalige termen nodig zijn voor de weergave van comparatieve begrippen: een vertaling ontbreekt in elke Engelse rechtstaal; er worden verschillende uitdrukkingen gebruikt in verschillende Engelse rechtstalen. Wat het eerste geval betreft: een vertaling van 'Rechtsgeschäft' in de nieuwe term 'legal transaction' is wellicht aanvaardbaar ${ }^{408}$. Als vertalingen ontbreken, moet worden verlangd dat de nieuwe term wordt ingevoerd voor een buitenlandse rechtsterm met hetzelfde abstractieniveau ${ }^{409}$. Twee voorbeelden kunnen dit toelichten. Zolang de Franse wetgever de rechtsterm 'fiducie' niet heeft geïntroduceerd ${ }^{410}$, is 'fiducie' een aanvaardbare nieuwe term. Dit geldt echter niet in het

401. Zie II. 2.B. Elk nummer is cen notatie, een verkorte schriffwijze (zie IV. 2.A) voor bedoelde categorie.

402. Cr: Dobrowolski, 37; cf. Pawlowski; 84.

403: Zie II: 3.C.

404. Kreuzer, 145 .

405. Cf. Baumann, 85, 88; of. Loth 1986, 248.

406. Ook neologismen genoemd. Nieuwe termen zijn termen niet in gebruik bij eet rechtsstelsel voor de weergave van een nationaal rechtsbegrip.

407. Zie 11.8. 4 .B sub (c) en (d).

408. De 'International Encyclopedia of Comparative Law' wordt in het Engels gepubliceerd. Cf. Weston, 28: het introduceren van een neologisme moet voor vertallers een laatste redmiddel zijn.

409. Cf. Sancevic, 286 .

410. In het Franse Burgerlijk Wetboek zou niet de trust maar een fiduciecontract worden ingevoerd: Herbots, 317. Dit wetsontwerp is inmiddels ingetrokken: Van Boeschoten 1994, 41 noot 150. Overigens heeft de wetgever wan Quebec voor trust het Franstalige equiwalent. "fiducie" geintroduceerd: art, 1260 BW van Quebec; Sacco, 29. 
geval van een afwijkend abstractieniveau tussen het Engelse en Franse recht ${ }^{4 i 1}$ : "unjust enrichment' suggereert een algemeen begrip voor het Engelse recht dat daarin ontbreekt ${ }^{412}$. De kans op miswerstanden is hier aanwezig.

Het is moeilijker on voor het tweede geval van Drobnig te aanvaarden dat "corporation" en 'share company" vervangen moeten worden door de nieuwe uitdrukking 'marketable share company". Dat de Engelse rechtsterm niet letterlijk hetzelfde is als de Amerikaanse rechtsterm, is onvoldoende reden voor deze vervanging. De nieuwe uitdrukking 'marketable share company' kan tot misverstanden aanleiding geven. Ook de term "appartment ownership" ${ }^{* 13}$ kan misverstanden oproepen met een rechtsterm die een of ander Engelstalig rechisstelsel gebruikt of waarmee men het meest vertrouwd is ${ }^{414}$. Om verwarring met bestaande termen te voorkomen moet een nieuwe term eenduidig zijin.

\section{\$ 5. Comparatieve begrippen in de toepassingsgebieden}

\section{A. RECHTSVERGELIJKING ALS HULPMIDDEL}

In de literatuur is de ontwikkeling van een systeem van comparatieve begrippen gerechtvaardigd met het indirecte nut voor de volgende toepassingsgebieden: rechtsvergelijkende ordeningssystemen, rechtsvergelijkende thesauri en de rechtsvergelijkende begripskwalificatie in het IPR. Dit indirecte nut wordt verwacht van een of ander rechtsvergelijkend classificatiesysteem ${ }^{415}$. Het beoogde systeem zou niet alleen toegepast kunnen worden om documenten te vinden voor rechtsvergelijkend onderzoek, maar ook om een oplossing voor het kwalificatieprobleem in het internationaal privaatrecht dichterbij te brengen. Dat blijkt uit de volgende desiderata ${ }^{416}$ : volgens De Groot zou een systeem van comparatieve begrippen niet alleen kunnen leiden tot een uniforme thesaurus, maar ook tot een classificatiesysteem voor bibliotheekcollecties met documenten over rechtsstelsels die verschillen qua indeling in rechtsgebieden. Bovendien zou dit systeem indirect nut bezitten voor het kwalificatieprobleem in het internationaal privaatrecht door

411. Omdat het Engelse recht meer casuïstisch is, kan een Engels rechtsbegrip een lager abstractieniveau hebben dan bijyoorbeeld wen Frams rechtsbegrip: cf. David 1992, 292-293.

412. Esser, 167: Mincke 1984, 323-324: ff. Samuel/Rinkes, 187. Een notatie in plats van een woord kan duideligk maken dat een woord ontbreekt voor het begrip in kwestie: cf. Dahlberg 1974, 285.

413. Zie II. 1.

414. Cf. Sauveplanne 1975a, 36-37.

415. Zie II.\$ 2.A en III \$ 4.A.

416. Zie II. 2.B. 
een oplossing te bieden voor uiteenlopende kwalificaties van situaties of rechtsregels. De laatste verwachting wordt gedeeld door Mincke en Kokkini.

Vermelde desiderata veronderstellen dat rechtsvergelijking hulpmiddel is voor de toepassingsgebieden. Daartoe is vereist dat daarin rechtsvergelijkende momenten aanwezig zijn. Dit moet eerst (in III. $\$ 5 . A$ ) worden besproken omdat rechtsvergelijking niet noodzakelijk is voor het bereiken van de doeleinden van de toepassingsgebieden. Het terugvinden van een document of de kwalificatie van een rechtsregel is mogelijk zonder toepassing van resultaten van rechtsvergelijkend onderzoek. Als rechtsvergelijking geen hulpmiddel is voor het bereiken van het doel van ordeningssystemen, thesauri of begripskwalificatie, kan er geen sprake zijn van toepassing van comparatieve begrippen: begrippen die in de rechtsvergelijking gehanteerd worden ${ }^{417}$. De aanwezigheid van rechtsvergelijkende momenten in de toepassingsgebieden moet aannemelijk zijn voordat wordt besloten tot een gedetailleerd onderzoek van die gebieden.

Het is aannemelijk dat rechtsvergelijking hulpmiddel is voor de constructie van ordeningssystemen of thesauri en voor de oplossing van het kwalificatieprobleem: een groepering van vergelijkbare rechtsstelsels zal behulpzaam zijn bij het terugvinden van documenten en bij het oplossen van een rechtsvraag die de grenzen van één rechtssysteem overschrijdt ${ }^{418}$. Een groepering van vergelijkbare rechtsstelsels in de toepassingsgebieden is een argument om verder onderzoek naar het indirecte nut van comparatieve begrippen te rechtvaardigen want comparatieve begrippen kunnen bijdragen aan een afbakening van vergelijkbare rechtsstelsels ${ }^{419}$. Een tweede argument is dat er in de toepassingsgebieden onderdelen van rechtsstelsels gerelateerd worden: in ordeningssystemen en thesauri worden documenten van verschillende rechtsstelsels tot éen notatie $^{420}$ of één descriptor ${ }^{421}$ herleid; in het IPR worden rechtsregels en rechtsbegrippen ${ }^{422}$ van verschillende rechtsstelsels vergeleken. Rechtsvergelijking zou een onmisbaar hulpmiddel voor de rechter zijn om oplossingen te ontdekken ${ }^{423}$ voor de kwalificatie an de hand van een nationale verwijzingscategorie die naar buitenlands recht verwijst ${ }^{424}$. Het terugvinden van een document of de kwalificatie van een rechtsregel kan

417. Zie hoofdstuk 1 .

418. Cf. Kokkini 1988a, 20.

419. Zie III.\$4.A.

420. Ziv IV.\$2.A.

421. Zie V.\$1.A.

422. Cf. Scholten, $155,168$.

423. Cf. Rugaux 1978, 67, 73, 77; of. Van Ginsbergen 1968, 356; cf. Vranken, 129, 131, 132.

424. Verheul, 66: de rechterlijke beslissing is ther bestend voor een internationale rechtskring. 
geschieden zonder rechtsvergelijkend classificatiesysteem. Afzonderlijke comparatieve begrippen kunnen nuttig zijn voor de drie toepassingsgebieden.

De voorlopige conclusie luidt dat comparatieve begrippen afzonderlijk toegepast kunnen worden in ordeningssystemen, thesauri of de begripskwalificatie. Deze toepassingsgebieden kunnen echter onoverkomelijke beperkingen bevatten voor de toepassing van comparatieve begrippen en daarmee het potentiële nut van comparatieve begrippen illusoir maken. Voorafgaand aan een gedetailleerd onderzoek in de volgende hoofdstukken moet ook aannemelijk zijn dat deze gebieden geen onoverkomelijke beperkingen bevatten. Dit wordt in de volgende paragraaf (III.\& 5.B) besproken.

\section{B. BEPERKINGEN IN DE TOEPASSINGSGEBIEDEN}

Het doel van ordeningssystemen en thesauri is het doen terugvinden van documenten die relevant zijn voor rechtsvergelijkend onderzoek. Daartoe worden documenten van verschillende rechtsstelsels tot één notatie of eén descriptor herleid. Als de notatie of descriptor de weergave is van een comparatief begrip, wordt een comparatief begrip toegepast op documenten omtrent verschillende rechtsbegrippen. De relevante documenten zullen voldoen aan buitenlandse begrippen ${ }^{425}$ die corresponderen ${ }^{426}$ met de begrippen van bijvoorbeeld het Nederlandse rechtssysteem waarmee een Nederlandse jurist documenten heeft gezocht ${ }^{427}$. Dat notaties of descriptoren comparatieve begrippen weergeven, kan echter verhinderd worden door onoverkomelijke beperkingen. Zo moet er rekening mee gehouden worden dat ordeningssystemen bestaan uit hiërarchische relaties tussen soortbegrippen ${ }^{428}$. Dit impliceert een beperking voor de vorm ${ }^{429}$ van comparatieve begrippen. Thesauri bevatten beperkingen voor de termen voor comparatieve begrippen: thesauri laten niet alle woorden toe als descriptoren, terwijl de relaties tussen de descriptoren genormaliseerd zijn ${ }^{430}$. Indien deze beperkingen ertoe leiden dat comparatieve begrippen niet toegepast kunnen worden binnen ordeningssystemen of thesauri, moet worden geconcludeerd dat comparatieve begrippen geen indirect nut hebben voor deze toepassingsgebieden.

425. Ook al kent de Nederlandse jurist het buitenlandse rechtssteisel en de buitenlandse rechtstanl niet of nauwelijks: cf. Baner 1973, 98, 113.

426. Nationale rechtsbegrippen met een gemeenschappelijk kenmerk zijn gerelateerd: cf. Dahlberg 1974, 102, 109 .

427. Cf. De Wild, 26; zie II. 2.B.

428. Zie IV. 1 .A.

429. Zie II. $\$ 1$.

430. Zie V.S 1.A. 
Aan het doel van de begripskwalificatie kunnen comparatieve begrippen bijdragen door een zodanige begripsworming dat de verwijzingscategorie een vergelijkende betekenis krijgt die niet beheerst wordt door én van de betrokken rechtsstelsels. De verwijzingsregel beoogt immers onpartijdig te zijn ${ }^{43 .}$. De toepassing van comparatieve begrippen ten behoeve van de begripskwalificatie kan nuttig zijn voor een zodanige precisering van de definitie van de verwijzingscategorie dat de rechter kan verwijzen naar een of ander rechtsstelsel. Met het additionele kenmerk 'affectieve relatie' kan bijwoorbeeld 'familierecht' verfijnd worden voor de kwalificatie van een verloving zodat de reikwijdte van de verwijzingscategorie 'fanilierecht' wordt afgebakend ten opzichte van de verwijzingscategorie "overeenkomstenrecht" ${ }^{432}$. Aan de literatuur zijn echter drie beperkingen te ontlenen. De volgende beperkingen kunnen de toepassing van comparatieve begrippen verhinderen:

(a) de verwijzingscategorie is geformuleerd in rechtstermen van een nationale verwijzingsregel ${ }^{433}$;

(b) het aantal verwijzingscategorieën is beperkt zodat er comparatieve begrippen zullen zijn met kenmerken die ontbreken in de gegeven verwijzingscategorie;

(c) de verwijzingscategorie is geen typebegrip, maar een soortbegrip ${ }^{434}$. Dit is een beperking voor de vorm ${ }^{435}$ van comparatieve begrippen.

Als er geen onoverkomelijke beperkingen zijn die de toepassing van comparatieve begrippen beletten, kunnen comparatieve begrippen indirect nut hebben voor de toepassingsgebieden. Daartoe moet worden aangetoond dat het doel van het betreffende toepassingsgebied wordt bereikt met behulp van comparatieve begrippen. Dit moet blijken uit de relevantie van de documenten gevonden met een ordeningssysteem of thesaurus. In het geval van de begripskwalificatie moet het indirecte nut van comparatieve begrippen blijken uit de precisie van de definitie van de verwijzingscategorie. Om het indirecte nut van comparatieve begrippen te bepalen, volgt eerst een analyse van de verschillende toepassingsgebieden: in de hoofdstukken IV, V en VI. Conclusies omtrent het indirecte nut van comparatieve begrippen worden in hoofdstuk VII getrokken. Het is mogelijk dat in de toepassingsgebieden nieuwe problemen worden gesignaleerd die repercussies zullen hebben voor het directe nut van comparatieve begrippen.

431. Zie VI.\$ 1.A, VI.\$1.B, VI.\$2.B en VI.\$2.C.

432. Cf. De Boom/etc, 454,461, 463 noot 65: ten aanzien wan een samenlevingscontract. Cf. Striewe, 388 noot 137, 394: de verloving wordt evenals het huwelijk gekenmerkt door een persoonlijke band waardoor er sprake is van een familterechtelijke verhouding.

433. Rabel 1958, 62.

434. Zie VI.\$2.C.

435. Zie II. $\$ 1$. 


\section{Rechtsvergelijkende ordeningssystemen}

\section{$\S 1$. De constructie van een ordeningssysteem}

\section{A. INDELEN VAN BEGRIPPEN}

De centrale vraag in dit hoofdstuk is: aan welke criteria moet een ordeningssysteem voor bibliotheekcollecties voldoen om rechtsvergelijkend onderzoek te vergemakkelijken? De beantwoording van deze vraag vereist de bespreking van een aantal deelproblemen die elkaar opvolgen. Eerst wordt nagegaan volgens welke beginselen begrippen worden ingedeeld in een ordeningssysteem. In $\S 1$ is de toepassing van een ordeningssysteem op een bibliotheekcoilectie met juridische documenten nog niet aan de orde. Vervolgens zal in $\& 2$ worden onderzocht of de algemene criteria voor een ordeningssysteem onverkort gelden voor een ordeningssysteem dat bestemd is voor documenten met betrekking tot éen rechtsstelsel. Dit ter voorbereiding op een uitwoerige behandeling van de classificatieproblemen die zich bij rechtsvergelijkende bibliotheekcollecties ${ }^{436}$ voordoen. In $\$ 3$ worden de problemen van rechtsvergelijkende ordeningssystemen besproken. Dan is het de vraag of de hoofdlijnen en de opbouw van het ordeningssysteem voor eén rechtsstelsel, geschikt zijn voor bibliotheekcollecties met documenten omtrent meer dan één rechtsstelsel. De beantwoording van deze vraag zal in $\$ 4$ plaatsvinden aan de hand van een aantal rechtsvergelijkende ordeningssystemen voor bibliotheekcollecties. Aan het belangrijke rechtsvergelijkende systeem van de Library of Congress Classification is $\S 5$ gewijd.

436. Althans bij bibliotheekcollecties die gericht zijn op rechitswergelijkend onderzoek: een bibliotheekcollectie kan op zichzelf niet rechtswergelijkend zijn. 
Het doel van een rechtsvergelijkend ordeningssysteem is het terugvinden van documenten omtrent een buitenlands rechtsbegrip met behulp van bijvoorbeeld een Nederlands rechtsbegrip dat daarmee correspondeert ${ }^{437}$. Of een rechtsvergelijkend ordeningssysteem comparatieve begrippen bevat die eventueel in een rechtsvergelijkend classificatiesysteem ${ }^{438}$ zijn ingedeeld, blijft in dit hoofdstuk buiten beschouwing. Dit hoofdstuk gaat over 'rechtsvergelijkende ordeningssystemen', niet over 'rechtsvergelijkende classificatiesystemen'. Dit hoofdstuk betreft evenmin het indirecte nut van comparatieve begrippen voor rechtsvergelijkende ordeningssystemen als toepassingsgebied. In dit hoofdstuk wordt onderzocht hoe rechtswergelijkende ordeningssystemen zijn geconstrueerd om rechtsvergelijkend onderzoek te vergemakkelijken. Het indelen van begrippen is het uitgangspunt van de constructie van een ordeningssysteem; daarover gaat de rest van deze paragraaf $(\$ 1$ 1.A). Veryolgens worden indelingskarakteristieken (in \& $1 . B$ ) besproken omdat zij kunnen voorkomen dat een ordeningssysteem zodanig wordt geconstrueerd dat de gebruiker documenten met veel gemeenschappelijke eigenschappen verspreid aantreft.

Een ordeningssysteem voor bijvoorbeeld een bibliotheekcollectie beoogt deze verzameling overzichtelijk te ordenen om het terugvinden van de objecten in die collectie te vergemakkelijken ${ }^{439}$. Het middel daartoe is het indelen van soortbegrippen. Een ordeningssysteem is ingedeeld in soortbegrippen ${ }^{440}$ en meer specifieke begrippen. Wanneer deze indeling herhaald wordt, ontstaat een groter geheel van soortbegrippen en meer specifieke begrippen. Een 'ordeningssysteem' is het systeem voor dit geheel van soortbegrippen en meer specifieke begrippen ${ }^{44}$. Aan elk ordeningssysteem ligt een indeling van begrippen in soortbegrippen en meer specifieke begrippen ten grondslag. Deze indeling begint met een ontleding van het soortbegrip in zijn kenmerken ${ }^{442}$. Vervolgens worden soortbegrippen ingedeeld in meer specifieke begrippen doordat aan de algemene ${ }^{443}$ kenmerken van het soortbegrip een soortmakend verschil wordt toegevoegd. Het soortmakend verschil is het kenmerk dat toegevoegd moet worden aan een soortbegrip om meer specifieke begrippen te verkrijgen; bijwoorbeeld: "lappen' plus 'blauw' geeft "blauwe lappen', 'lappen' plus 'rood" geeft "rode lappen', enzovoorts ${ }^{444}$. Elk specifiek begrip kan op zijn beurt worden behandeld als cen soortbe-

437. Zie III. 5.B.

438. Zie III. 4.A.

439. Engisch 1973, 148; of. 150 .

440. Zie II. \& 1 .

441. Cf. Engisch 1968, 171-172 noot 72: de terminologie is allerminst vast.

442. Dahilberg 1974, 21 .

443. Worden ook 'getneenschappelijke" of "generieke" kenmerken genoemd.

444. Cf. Groeneveld, 234-235. 
grip waaraan weer een soortmakend verschil wordt toegevoegd ${ }^{445}$. De meer specifieke begrippen zijn specifieker omdat ze dankzij het soortmakend verschil meer kenmerken bezitten dan het soortbegrip ${ }^{446}$. Het soortmakend verschil specificeert het soortbegrip in meer specifieke begrippen.

Tussen het soortbegrip en de meer specifieke begrippen bestaat een hiërarchische relatie $^{447}$ : de meer specifieke begrippen zijn ondergeschikt aan het hogere soortbegrip. Aan het hogere begrip is een groter aantal meer specifieke begrippen ondergeschikt. Het hogere soortbegrip kan zich vertakken in twee lagere begrippen, bijvoorbeeld "koolwaterstoffen' en 'niet-koolwaterstoffen'. Dit is de eenvoudigste vorm van een ordeningssysteem $^{448}$. Een dichotomie is echter niet noodzakelijk ${ }^{449}$. De vertakkingen van het hogere soortbegrip vormen een begrippenpiramide. Deze begrippenpiramide is opgebouwd uit hiërarchische relaties tussen hogere soortbegrippen en ondergeschikte, meer specifieke begrippen. Aan de top van de begrippenpiramide staat het hoogste soortbegrip ${ }^{450}$, de grondslag van het ordeningssysteem. Het geheel van soortbegrippen en hiërarchische relaties is een ordeningssysteem. Er is sleclits een gradueel onderscheid tussen afzonderlijke soortbegrippen enerzijds en een ordeningssysteem anderzijds ${ }^{451}$. Een ordeningssysteem met een begrippenpiramide komt tot stand door de herhaalde indeling van soortbegrippen.

Bij de specificatie van soortbegrippen dienen de volgende regels in acht genomen te worden: er dient te worden voorkomen dat iets tegelijk soortbegrip en meer specifiek begrip is ${ }^{452}$; en het soortbegrip mag niet in tegenspraak met het meer specifieke begrip zijn doordat een kenmerk van het soortbegrip in het meer specifieke begrip wordt ontkend ${ }^{453}$. Voorts wordt verlangd dat de extensie ${ }^{454}$ niet gedeeltelijk samenvalt met de extensie van een ander soortbegrip ${ }^{455}$ en dat het domein wordt uitgeput door alle soortbegrippen tezamen ${ }^{456}$. De laatste regel verlangt van het ordeningssysteem

445. Cr. Langitidge, 15 .

446. Dahlberg 1974, 21.

447. Cf. Dahilberg 1974, 22.

448. Groeneveld, 235 .

449. Engisch $1973,131,143$.

450. Engisch $1973,131$.

451. Engisch 1973, 128 .

452. Herberger/Simon, 295.

453. Cf. Broadfield, 2 ; cf. Engisch 1968, 165, 169.

454. Zie II $\$ 1$.

455. Nederlandse Classificatie Sticliting, 29: dit is een streven.

456. Cf. Groeneveld, 240-241; cf. Mills, 25-26. 
een volledige dekking doordat alle objecten worden omvat door extensies van de soortbegrippen ${ }^{457}$. Elk object moet onder een soortbegrip vallen ${ }^{458}$. Het is echter geen vereiste dat de kenmerken van het meer specifieke begrip afgeleid moeten worden van de kenmerken van het soortbegrip ${ }^{459}$. Er zijn twee mogelijkheden: ofwel het soortmakend verschill dat wordt gecombineerd met het soortbegrip, is inherent aan datzelfde soortbegrip; ofwel de specificatie van het soortbegrip geschiedt door toevoeging van een extern soortmakend verschil ${ }^{460}$.

Het kenmerk van het soortbegrip is het criterium voor de toepassing van dat soortbegrip op een object ${ }^{461}$. Zonder soortbegrippen kunnen objecten niet in klassen worden onderverdeeld ${ }^{462}$. Het kenmerk van het soortbegrip maakt het mogelijk om te beslissen dat een of ander object behoort tot de klasse van dat soortbegrip ${ }^{463}$. De klasse van het soortbegrip is geen willekeurige verzameling van objecten ${ }^{464}$. Er is een onderscheid tussen klasse en 'verzameling' dat zich als volgt laat illustreren: het bos is een verzameling bomen zonder daarvan de klasse te zijn. Van een afzonderlijke boom kan niet zinvol worden gezegd dat het tevens een bos is; daarentegen kan van een linde of pijnboom worden beweerd dat het tevens bomen zijn zodat ze behoren tot de klasse 'bomen'. Is 'bos' geen verzameling maar een klasse dan behoren daartoe bijzondere bossen, bijvoorbeeld bossen van coniferen ${ }^{465}$. De verdeling van een geheel in delen, bijvoorbeeld van een continent in landen, levert geen klassen op ${ }^{456}$. Er is pas sprake van een klasse als gemeenschappelijke kenmerken van een soortbegrip van toepassing zijn.

Soortbegrippen in een ordeningssysteem zullen hierna 'classificatiebegrippen' worden genoemd: Classificatiebegrippen kunnen meer of minder specifieke begrippen zijn. Classificatiebegrippen verschillen onderling door de specifieke kenmerken die aan hun gemeensehappelijke kenmerken zijn toegewoegd. Meer specifieke begrippen kunnen op hun beurt soortbegrippen zijn ten opzichte van classificatiebegrippen die zich nog lager

457. Cf. Merberger/Simon, 255, 277 .

458. Kuhlen 1977,34 .

459. Cf. Engisch 1968, 165, 171; cf. Engisch 1973, 134, 138.

460. Het is afluankelijk van de definitie van de hogere begrippen of hun specificaties tevens modificaties van de generieke kenunerken zijn: Engisch 1973, 137; of. Engisch 1968, 163.

461. Zie II. \$1.

462. Eisenmann, 34 .

463. Cf. Wersig, 18.

46. Cf. Brondfield, 26.

465. Dobrowalski, 8 .

466. Cf. Dobrowolski, 27. 
in de hiërarchie bevinden. Alle classificatiebegrippen bevinden zich, ongeacht de mate van specificiteit, in de begrippenpiramide van een ordeningssysteem. Bij elk classificatiebegrip hoort een klasse van objecten; de extensie van die klasse is kleiner ${ }^{467}$ als het corresponderende classificatiebegrip specifieker is.

\section{B. KEUZE VAN INDELINGSKARAKTERISTIEKEN}

De 'indelingskarakteristiek' is het criterium om te bepalen welk soortmakend verschil toegestaan is ter specificatie van het hogere soortbegrip. Terwijl de ene indelingskarakteristiek de combinatie van een soortbegrip met een soortmakend verschil toestaat; verbiedt de andere indelingskarakteristiek de specificatie van een soortbegrip met datzelfde soortmakende verschil. De indelingskarakteristieken van een ordeningssysteem bepallen de hoofdlijnen van de opbouw van dat ordeningssysteem. De indelingskarakteristieken zijn de gezichtspunten volgens welke de klassen van dat ordeningssysteem worden ingedeeld. Binnen eenzelfde ordeningssysteem zijn verschillende indelingskarakteristieken mogelijk waar de te classificeren objecten diverse eigenschappen bezit$\operatorname{ten}^{468}$. Daarom is de keuze van indelingskarakteristieken van belang.

Het volgende voorbeeld ${ }^{46 \%}$ kan het gebruik van indelingskarakteristieken illustreren. De klasse 'schoenen' kan worden ingedeeld naar twee indelingskarakteristieken: 'kleur" en 'geslacht en leeftijd van de drager'. Volgens de eerste indelingskarakteristiek moeten de schoenen worden onderscheiden naar kleur en kan de klasse 'schoenen' dienovereenkomstig worden onderverdeeld in 'rode schoenen', 'bruine schoenen' enzovoorts. Hier is de indelingskarakteristiek 'kleur' het gezichtspunt dat bepalend is voor rode en bruine schoenen. Volgens de tweede indelingskarakteristiek moeten de schoenen worden onderscheiden naar geslacht en leeftijd van de drager, en kan de klasse 'schoenen' worden ingedeeld in "herenschoenen", 'meisjesschoenen' enzovoorts. De indelingskarakteristie ken moeten niet worden verward met de grondslag van het ordeningssysteem: het soortbegrip "schoenen". Deze basis is kenmerkend voor alle classificatiebegrippen van het ordeningssysteem ${ }^{470}$. Deze grondslag moet voldoende algemeen zijn zodat de specificaties van het hoogste soortbegrip de te classificeren objecten kuninen omvatten ${ }^{471}$. Het domein moet immers worden uitgeput ${ }^{472}$. Of dat lukt is primair afhankelijk van

467. Cf. Dobrowolski, 11: de extensie van bijzondere klassen is kleiner. Cf. Herberger/Simon, 251.

468. Cf. Eisiemmann, 36-37.

469. Nederlandse Classificatie Stichting, 8, 25 .

470. Cf. Dobrowolski, 46.

471. Cf. Dobrowolsk:, 253.

472. Zie IV.\$1.A. 
de keuze van de generieke kenmerken van het hoogste soortbegrip. De generieke kenmerken van de soortbegrippen kunnen niet in volledige vrijheid worden gekozen ${ }^{473}$.

De gekozen indelingskarakteristiek dient consequent te worden toegepast bij het affeiden van alle direct ondergeschikte begrippen uit het soortbegrip. De indelingskarakteristiek moet bepalend zijn woor de keuze van de specifieke kenmerken van de lagere classificatiebegrippen. Dit wordt verlangd door het beginsel van eenheid van indelingskarakteristiek. Het verbiedt dat op hetzelfde classificatieniveau sommige schoenen naar kleur en andere schoenen naar geslacht en leeftijd van de drager worden ingedeeld. De indelingskarakteristiek 'kleur' staat de klasse 'herenschoenen" niet toe. Het consequent toepassen van een indelingskarakteristiek bevordert de overzichtelijkheid van het ordeningssysteem ${ }^{424}$. Het beginsel van eenheid van indelingskarakteristiek is echter niet dwingend. Het is mogelijk dat de ene vertakking volgens een andere indelingskarakteristiek wordt gespecificeerd dan de andere vertakking ${ }^{475}$. De klasse 'schoenen' kan deels worden onderverdeeld naar kleur en deels naar geslacht en leeftijd van de drager. Het gevolg daarvan is dat 'bruine herenschoenen' in meer dan één klasse ingedeeld kunnen worden ${ }^{476}$ : ze voldoen zowel aan de kenmerken van het soortbegrip "bruine schoenen" als aan die vân het soortbegrip 'herenschoenen'. Beide klassen sluiten elkaar niet volledig uit ${ }^{477}$. Dit doet afbreuk aan de overzichtelijkheid van het ordeningssysteem.

De indelingskarakteristieken kunnen verschillen voor verschillende trappen van subordinatie. Voor het eerste classificatieniveau kan een andere indelingskarakteristiek worden gekozen dan voor de indeling van de tweede orde ${ }^{478}$. Om terug te komen op het voorbeeld van de lappen: op het eerste niveau kan worden onderverdeeld naar kleur om vervolgens op het tweede plan zowel de blauwe als de rode lappen verder te verdelen naar bijvoorbeeld de stof waaruit elke klasse is samengesteld. Bij een indeling van de derde orde kunnen de lappen die reeds zijn onderscheiden naar kleur en samenstelling, nog eens naar afmeting worden ingedeeld. In dit voorbeeld doen zich vertakkingen woor die per classificatieniveau door een andere indelingskarakteristiek zijn bepaald: kleur, samenstelling respectievelijk afmeting. Deze afwisseling van indelingskarakteristieken is niet in strijd met de eenheid van indelingskarakteristiek: dit principe geldt slechts op

473. Cf. Engisch 1973, 150: de keuze van de generieke kenmerken draagt bij aan het slagen wan een ordeningssysteen.

474. Nederhandse Classificatie Stichting, 24.

475. Cr. Engisch 1973, 142.

476. Cr. Mills, 15; of. Nederlandse Classificanie Stichting, 25.

477. Cf. Langridge, 15 .

478. Cf. Groeneveld, 237, 239. 
hetzelfde niveau. Dit beginsel is evenmin van toepassing op de volgorde van indelingskarakteristieken voor de verschillende trappen van subordinatie.

De volgorde van indelingskarakteristieken kan worden bepaald door de omstandigheid dat een aantal begripskenmerken de logische voorwaarde is voor andere begripskenmerken $^{479}$. Overigens is de volgorde van indelingskarakteristieken afhankelijk van het doel van het ordeningssysteem ${ }^{480}$. De behoeften van de gebruikers van het ordeningssysteem bepalen de volgorde van de indelingskarakteristieken ${ }^{48 i}$. Als die gebruikers vooral geïnteresseerd zijn in de kleur van schoenen moet de indelingskarakteristiek 'geslacht en leeftijd van de drager' op de tweede plaats komen. Dan worden rode en bruine schoenen onderverdeeld in meisjesschoenen en herenschoenen. De meisjesschoenen en de herenschoenen zijn echter verspreid over de kleurgroepen. Wil men dat voorkomen, dan moet 'geslacht en leeftijd van de drager' de eerste indelingskarakteristiek zijn zodat de rode en de bruine schoenen zowel bij de meisjesschoenen als bij de herenschoenen zijn aan te treffen. Dan zijn de kleurgroepen verspreid. Dat is ondoelmatig voor de gebruikers van het ordeningssysteem die vooral geïnteresseerd zijn in de kleur.

Zelfs de meest eenvoudige objecten bezitten vele eigenschappen waardoor deze objecten kunnen behoren tot verschillende klassen voor objecten met gemeenschappelijke eigenschappen ${ }^{482}$. De keuze en de volgorde van indelingskarakteristieken bepalen met welk specifiek classificatiebegrip het object wordt ingedeeld in het ordeningssysteem. Daarbij is de keuze van de eerste indelingskarakteristiek cruciaal voor de doelmatigheid van het ordeningssysteem. Het volgende voorbeeld ${ }^{483}$ kan dit illustreren: men kan de eerste indelingskarakteristiek van een ordeningssysteem zodanig kiezen dat alles wat op én been, alles wat op twee benen en alles wat op vier benen staat, tot een afzonderlijke hoofdklasse worden gerekend. Deze constructie staat toe: (1) bomen, bergen, en ooievaars; (2) mensen, kippen en poorten; (3) paarden, stoelen, en wagens bij een andere hoofdklasse in te delen. Dit ordeningssysteem is ondoelmatig omdat objecten die veel eigenschappen gemeenschappelijk hebben, verspreid worden over verschillende hoofdklassen ${ }^{484}$. Bovendien worden in dezelfde hoofdklasse objecten aangetroffen die meer verschillende dan gemeenschappelijke eigenschappen blijken te bezitten zodra men het

479. Cf. Engisch 1968, 172 noot 72; cf. Engisch 1973, 141.

480. Dobrowolski, 18; Mills, 29.

481. Buclianan, 38-39; Mills, 13.

482. Cf. Langridge, 6 .

483. Glastra van Loon, 105.

484. Cf. Eisenmann, 40,42 . 
ordeningssysteem confronteert met ervaringsgegevens ${ }^{485}$. De eigenschappen van objecten zijn ervaringsgegevens die niet verwaarloosd kunnen worden ${ }^{486}$.

Het doel van een ordeningssysteem is bepalend voor de inhoud en de hoofdlijnen ervan $^{487}$. Een ordeningssysteem is een doelmatig ordeningsinstrument als er rekening wordt gehouden met ervaringsgegevens. Een ordeningssysteem moet worden beoordeeld op zijn doelmatigheid ${ }^{488}$ voor de objecten waarop het ordeningssysteem betrekking heeft. Deze uitgangspunten zijn van belang voor de constructie van ordeningssystemen voor juridische documenten in een bibliotheekcollectie.

\section{\$2. Juridische ordeningssystemen}

\section{A. KLASSEREN VAN JURIDISCHE DOCUMENTEN}

Een ordeningssysteem beoogt het ordelijk indelen van objecten zodat die kunnen worden teruggevonden. Het doel van een juridisch ordeningssysteem voor juridische documenten $^{489}$ in een bibliotheekcollectie is daarvan afgeleid. Juridische documenten worden ingedeeld in de klasse van het toepasselijke classificatiebegrip. Dit indelen wordt "klasseren' genoemd. Door juridische documenten te klasseren wordt deze objecten een eigen plaats toegekend in het ordeningssysteem ${ }^{490}$. Indien het klasseren correct geschiedt, worden juridische documenten over hetzelfde onderwerp op dezelfde plaats aangetroffen.

De notatie ${ }^{491}$ is de aanduiding van de plaats van juridische documenten binnen het geheel van een ordeningssysteem. De notatie is een verkorte schrijfwijze: een combinatie van cijfers, van letters of van cijfers en letters. Notaties kunnen in de plaats van het

485. Cf. Plato 46 (Phaedrus 265e): men mag niet als een onhandige slager lukraak stukken afhakken.

486. Cf. Enguisch 1968,29 noot 83,171 .

487. Cf. Dobrowolski, 18

488. Langridlge, 10 ; cf. Langridge 20.

489. Objecten in een bibliotheekcollectie zijn documenten. Documenten zijn teksten zoals boeken en tijdschriftartikelen: cf. Van de Walle, 45. Juridische documenten zijn teksten die juridische zinnen bevat. win: cf: Knapp, 275; of. Lehto" 168 . Niet als juridische documenten worden beschouwd: certificaten, testamenten; of contracten die rechten of verplichtingen met zich brengen: cf. Lehto, 170-171. Deze categorie juridische documenten blifft hier butten beschouwing omdat die gewoonlijk niet in een bibliotheekcollectie is opgenomen.

490. Cf. Groeneveld, 224-225: 'klasseren' is te onderscheiden wan 'classificeren', het construeren van een ordeningssysteem.

491. Ook onderwerpsingang of systematische code genoemd. 
overeenkomstige classificatiebegrip worden gebruikt ${ }^{492}$. Zij fixeren de hele indeling van een ordeningssysteem ${ }^{493}$. Notaties zijn een hulpmiddel bij het ordeningssysteem ${ }^{44}$. Als de notaties de hiërarchische relaties tussen de classificatiebegrippen van een ordeningssysteem volgen, is er sprake van een "expressieve notatie" ${ }^{495}$. Aan een expressieve notatie is te zien welke plaats het classificatiebegrip inneemt in de hiërarchie van het ordeningssysteem. Bijvoorbeeld: ' $\mathrm{K} \mathrm{10}$ ' is de notatie voor een hoger begrip, de decimale notatie ' $\mathrm{K} 10.1$ ' staat voor een lager begrip. Vervolgens kan de notatie ' $\mathrm{K} 10$ ' worden toegekend aan een document over wilsgebreken en ' $\mathrm{K} 10.1^{\prime}$ ' an een document over dwaling. Daarmee wordt aangegeven dat het corresponderende classificatiebegrip van toepassing is op het geklasseerde document. Juridische documenten met dezelfde inhoud moeten worden ingedeeld in dezelfde klasse met dezelfde notatie ${ }^{496}$. De intensie van het classificatiebegrip is het criterium voor de toepassing van de notatie. De inhoud van het document moet beantwoorden aan die intensie. Daarom moet voor de toekenning van een notatie worden vastgesteld wat de inhoud van het document is. Daartoe is vereist dat de inhoud van het te klasseren document geanalyseerd wordt. Deze inhoudsanalyse is noodzakelijk ${ }^{497}$ voor het klasseren van juridische documenten.

Een ordeningssysteem voor bibliotheekcollecties bevat niet alleen notaties maar ook rubrieksomschrijvingen ${ }^{498}$. Een 'rubrieksomschrijving' bestaat uit één of meer ${ }^{499}$ termen die een classificatiebegrip representeren. Evenals notaties zijn rubrieksomschrijvingen een hulpmiddel voor het klasseren en terugvinden van juridische documenten. De intensie van het classificatiebegrip is beslissend voor de keuze van een notatie, niet de rubrieksomschrijving in één of meer termen. Als documenten slechts met behulp van de rubrieksomschrijving worden geklasseerd, bestaat het gevaar dat een onjuiste notatie wordt toegekend. Dan vindt de gebruiker van het ordeningssysteem irrelevante documenten; bijvoorbeeld via de notatie 'K 10.1 ' niet alleen documenten over 'dwaling'. Het

492. Cf. Dahlberg 1974. I1S. Notaties kunnen worden gecombineerd met logische operatoren: cf: Gödert. 165. Zie datarover V.\$2.A.

493. Dobrowolski; 84 ; ef. Moys 1976,556 .

494. Cff. Groeneveld, $241-242$.

495. Cf. Van Laer 1982, 149. In het geval van een expressieve notatie kan een zoekactie worden verbreed tot het hogere begrip: Svenonius 1983, 76. Bijwoorbeeld: door de decimaal ". I" te laten vallen wordt de zoekactie uitgebreid naar ' $\mathrm{K} 10^{\prime}$ inclusief $\mathrm{K}$ 10.1'. Het weglaten van een decimaal kan gesclieden met de truncatiefaciliteit: Gödent, 165. Zie daarover V.\$2.A en V.\$2.B.

496. Cf. Moys 1976, 576.

497. Cf. Riesthuis/Wijnands, 11 .

498. Cf. Wersig, 18: een rubrieksomschrijwing is uitgedrukt in een natuurlijke taal, een notatie is een kunstmatige aanduiding.

499. Het poneren van equivalentie van quasi-synoniemen (zie V. 1 .A.) dient zorgvuldig te geschiedem: Gödert, 160,162 . 
is ook mogelijk dat relevante documenten door onjuiste notaties niet gevonden worden ${ }^{500}$.

De inhoud van een document moet beantwoorden aan de intensie van een classificatiebegrip. Dit leidt tot de vraag waaruit de inhoud wan juridische documenten bestaat. De verschijningsworm ${ }^{50 !}$ van juridische documenten is te onderscheiden van de inhoud ${ }^{502}$. Dit onderscheid is moeilijk te maken voor 'wetgeving' dat zowel verschijningsvorm als onderwerp kan zijn ${ }^{303}$. De inhoud van juridische documenten is primair voor het klasseren. De inhoud wan een document moet worden gedistilleerd uit de woorden en zinnen die het bevat. Daartoe gaat degene die klasseert af op een aantal indicaties voor de inhoud van het juridisch document zoals de titel, de inhoudsopgave, het voorwoord, de inleiding, de samenvatting, het register, enzovoorts ${ }^{504}$. Deze inhoudsanalyse moet leiden tot de vaststelling van het rechtsbegrip ${ }^{505}$ dat in het document wordt behandeld. De inhoud van juridische documenten kan worden samengevat in rechtsbegrippen die worden geklasseerd met classificatiebegrippen ${ }^{506}$. Met een classificatiebegrip kan een document over een rechtsbegrip worden teruggevonden.

Het klasseren van een document geschiedt met de classificatiebegrippen van een juridisch ordeningssysteem. Deze classificatiebegrippen zijn te onderscheiden van de 'rechtsbegrippen" 507 van een rechtsstelsel. Rechtsbegrippen hebben een ander object dan elassificatiebegrippen. Niet documenten maar rechtsregels zijn het object van rechtsbegrippen. Rechtsbegrippen verwijzen naar rechtsnormen ${ }^{508}$ "Classificatiebegrippen verwijzen naar documenten omtrent rechtsbegrippen die op hun beurt verwijzen naar

500. Zie V.\$2.B over opbrengst en pracisie.

501. Of juridische documenten het licht zien als (losbladige) boeken, tijdschriften of feestbundels, is niet bepalend woor de ithoud.

502. Cf. Riesthuis/Wijhands, 12: de bibliografische worm iss strikt genomen geen deel van het onderwerp.

503. Cf. Steiner 1974b 11 ; $\mathrm{cf}$. Riesthuis/Wijnands, 119 . Het onderscheid ussen primaire literatuur (bijvoorbeeld wetgevingy enerzijds en secundaire litheratuur (bijwoorbeeld commentaren) anderzijds, is een onderscheid van verschijningsvorm respectievelijk onderwerp: Moys 1976, 555. Dit onderscheid moet in een ordeningssysteem tot uitdrukking komen: Kreuzer, 143.

504. Cr. Birch, 793 794 ten aamzien wan boeken. Moys 1992, xwi: men kan nooit alleen op de titel afgaan omdat de titel waak geen aunwijzing geeft omtrent het behandelde rechtsstelsel.

505. Cf. Van de Walle, 55.

506. Cf. Dobrowolski, 7, 32, 37; cf. Moys 1976, 548.

507. Of rechtsbegrippen onmiddelijk uit eén of meer juridische zinnen worden gedistilleerd of door de rechtswetenschap worden gevormd, blifft hier buiten beschouwing: cf. Engisch 1958, 60, Engisch 1968,164 ; en Eingisch 1973, 129, 149 noot 68 .

508. Cf. Dahlberg 1974, 18: met begrippen kumen objecten geïdentificeerd worden. 
rechtsnormen ${ }^{509}$. Met classificatiebegrippen kunnen rechtsnormen via de gekilasseerde documenten gelokaliseerd worden. Er is bovendien een onderscheid tussen een juridisch ordeningssysteem voor documenten in een bibliotheekcollectie en een rechtssysteem van rechtsbegrippen ${ }^{510}$. Een rechtssysteem ${ }^{511}$ kan afwijken van de indeling van een juridisch ordeningssysteem. Een ordeningssysteem is gericht op het gebruikersgemak waardoor ook rekening wordt gehouden met het tezamen behandelen vain thema's in de juridische literatuur. Zo worden voor het gemak van de gebruiker documenten over 'chattel mortgage' ingedeeld bij 'security' en niet bij 'personal property" ${ }^{5 / 2}$. Het gemak van de gebruiker is echter een nogal willekeurig criterium ${ }^{513}$; het rechtssysteem moet de indeling van een juridisch ordeningssysteem zoveel mogelijk bepalen.

Het is niet noodzakelijk dat de hiërarchische relaties tussen de classificatiebegrippen van een ordeningssysteem een exacte afspiegelling zijn van de hiërarchische relaties tussen de rechtsbegrippen in een rechtssysteem. Toch moet een juridisch ordeningssysteem zoveel mogelijk aansluiten bij een rechtssysteem; er moet naar parallellie gestreetd worden ${ }^{5 / 4}$. Voor het terugwinden van juridische documenten is het van belang dat de hiërarchische relaties van het ordeningssysteem zoveel mogelijk aansluiten bij die van het rechtssysteem. Het is ondoelmatig dat documenten omtrent 'chattel mortgage', een rechtsbegrip ingedeeld bij 'personal property' 515 , door het ordeningssysteem worden ondergebracht in de klasse voor 'security'. Deze discrepantie tussen rechtssysteem en ordeningssysteem is slechts doelmatig als het gebruikersgemak zwaar weegt omdat genoemde thema's tezamen worden behandeld in de literatuur.

\section{B. RECHTSGEBIEDEN EN POLYHIËRARCHIE}

De verenigbaarheid van rechtssysteem en ordeningssysteem levert problemen op bij polyhiërarchische relaties van rechtsbegrippen die ondergeschikt zijn aan meer rechtsge-

509. Cf. Knapp, 275.

510. Hier wondt werondersteld dat een rechtssysteem vil rechtsbegrippen begtat; of. Kamphuisen, 76. Rechtsbegrippen hebben op hun beurt betrekking op rechtsnomen: Eltzbacher, 18, 33. 82. Het rechtssysteem bestaat niet alleen uit rechtsbegrippen nuar ook uit rechtregels. Hier worden rechtsregels num opgevat zodat ze rechtsbeginselen omvatten. Overigens worden rechtsregels in enge zin onderscheiden wan rechtsbeginselen: Esser, 95: Scholten, 62-68.

511. Het rechtssystem is niet alleen een didactische of informatieve ordening, maar ook een mieuww interpretatie van bestaande begrippen getet op matschappelijke ontwikkelingen: Van Hoecke, 193-194.

512. Ellinger 1964, 363. Zie IV.8 5.C.

513. Ellinger 1949,82 noot 16,83 .

514. Bauer 1982, 241.

515. Zie III. 3.B. 
bieden. Het aansluiten bij polyhiërarchische relaties in het rechtssysteem vereist dat de ene vertakking van het ordeningssysteem wordt gespecificeerd volgens een andere indelingskarakteristiek dan de andere vertakking. Dit is in beginsel toegestaan omdat het beginsel van indelingskarakteristiek niet dwingend is. Heterogene indelingskarakteristieken op hetzelfde classificatieniveau brengen echter onoverzichtelijkheid met zich $^{516}$. Dit is niet doelmatig voor de gebruikers.

Binnen het rechtssysteem doen zich met traditionele rechtsgebieden en functionele rechtsgebieden ${ }^{517}$ twee verschillende vertakkingen op hetzelfde plan voor. Een document omtrent de geneeskundige behandelingsovereenkomst kan zowel binnen het traditionele burgerlijke recht als binnen het functionele gezondheidsrecht ingedeeld worden ${ }^{518}$. Als een juridisch ordeningssysteem deze indeling volgt, zullen twee verschillende indelingskarakteristieken op hetzelfde niveau met zich brengen dat lagere classificatiebegrippen onder meer dan én rechtsgebied vallen. Dan is er ook binnen het ordeningssysteem een polyhiërarchie omdat het ondergeschikte classificatiebegrip twee hiërarchische relaties heeft tot twee hogere begrippen ${ }^{519}$. Deze polyhiërarchie heeft tot gevolg dat de plaats van het ondergeschikte begrip in het ordeningssysteem niet eenduidig is vast te leggen ${ }^{520}$. Als op hetzelfde plan indelingskarakteristieken voor traditionele en functionele rechtsgebieden worden gehanteerd, kunnen de documenten ontrent de geneeskundige behandelingsovereenkomst op twee plaatsen aangetroffen worden. Dit zal het terugvinden van juridische documenten bemoeilijken.

Het kan doelmatig zijn het ordeningssysteem zodanig te construeren dat de ondergeschikte begrippen volledig onder één en slechts één rechtsgebied vallen. Daartoe moeten samengestelde rechtsbegrippen ${ }^{521}$ vereenvoudigd worden tot enkelvoudige classificatiebegrippen. Deze enkelvoudige classificatiebegrippen passen in één vertakking van het ordeningssysteem. Bijvoorbeeld: het samengestelde rechtsbegrip 'appartementsrecht' valt zowel onder 'eigendonsrecht' als onder 'verenigingsrecht'. Het rechtsbegrip 'appartementsrecht' kan vereenvoudigd worden tot 'mede-eigendom' ${ }^{522}$. Het enkelvoudige classificatiebegrip 'mede-eigendom' is onafhankelijk van het classificatiebegrip 'lidmaatschap van een vereniging van appartementseigenaren'. Het classificatiebegrip 'medeeigendom' valt uitsluitend onder het rechtsgebied 'eigendomsrecht'. Het nadeel van deze

516. Zie IV. 1.B.

517. Zie 1II.\$3,B.

518. Cf. Van Laeri 1990, 104.

\$19. Cf. Dathlberg 1974, 108.

\$20. Grunwald, 19.

521. Soortbegrippen met vertbonden kenmerkem: zie $11 . \$ 1$.

522. Zie III.\$1. 
vereenvoudiging is dat het enkelvoudige classificatiebegrip minder specifiek is dan het samengestelde rechtsbegrip zodat er irrelevante documenten gevonden worden ${ }^{523}$. Het nadeel van geringere precisie moet worden afgewogen tegen de grotere overzichtelijkheid van het ordeningssysteem.

\section{OPVOLGINGSKARAKTERISTIEKEN}

Indelingskarakteristieken leggen de volgorde van nevengeschikte classificatiebegrippen niet vast. Bijvoorbeeld: als schoenen worden onderscheiden naar kleur blijft de volgorde wan 'rode schoenen' en 'bruine schoenen' in het midden. De volgorde op dezelfde trap wan subordinatie wordt niet bepaald door indelingskarakteristieken maar door 'opvolgingskarakteristieken'. Deze opvolgingskarakteristieken bevorderen dat de volgorde van nevengeschikte classificatiebegrippen samenhangt met de eigenschappen van de objecten in de klassen. Opvolgingskarakteristieken woorkomen dat documenten met veel gemeenschappelijke eigenschappen verspreid raken op dezelfde trap van subordinatie. Zo kan voor de volgorde van de gekleurde schoenen aansluiting worden gezocht bij de volgorde van kleuren in de regenboog ${ }^{524}$. De fixatie door opvolgingskarakteristieken is echter zwakker dan die door indelingskarakteristieken ${ }^{525}$. Als er geen opvolgingskarakteristiek gevonden kan worden in de eigenschappen van de objecten moet er een ander criterium worden gezocht, bijvoorbeeld een traditie of een conventie, of desnoods de alfabetische volgorde van de termen die de classificatiebegrippen representeren ${ }^{526}$. Eventueel kunnen er chronologische of geografische criteria worden toegepast ${ }^{527}$.

Voor het gemak van de gebruikers is het doelmatig dat de volgorde van nevengeschikte classificatiebegrippen in juridische ordeningssystemen overeenstemt met die van rechtsbegrippen van rechtssystemen. Een opvolgingskarakteristiek ontleend aan rechtsbegrippen verdient de voorkeur boven criteria zoals traditie, conventie of alfabetische volgorde. Dit leidt tot de vraag welke opvolgingskarakteristiek gemeenschappelijk is aan rechtsbegrippen op dezelfde trap van subordinatie. Daarop kan worden geantwoord dat een reeks van rechtsbegrippen moet beginnen met de belangrijkste begrippen: dragende

523. Zie V. 2.B over opbrengst en precisie.

524. Cf. Loth 1987, 363: volgens de Sapir/Whorf-hypothese is het kleurenspectrum in verschillende talen anders samengesteld. Verificatie van die hypothese zou impliceren dar de regenboog geen taatonafhamkelijke volgorde biedt.

525. Groeneveld, 237.

526. Cf. Nederlandse Classificatie Stichting, 7, 27. Een alfabetsche volgorde is overigens beperkt tot eén linguistische taal: Goldberg 1986, 333 .

527. Groeneweld, 237 ; ef. Mills, 24. 
begrippen die eenheid in het rechtssysteem brengen ${ }^{528}$. Dergelijke rechtsbegrippen moeten voorafgaan aan minder belangrijke rechtsbegrippen. Dit uitgangspunt biedt echter geen hanteerbare opvolgingskarakteristiek voor een reeks van even belangrijke rechtsbegrippen of rechtsgebieden. Een dwingende volgorde zou vereisen dat rechtsgebied A een noodzakelijke voorwaarde is voor rechtsgebied B, en dat rechtsgebied B op zijn beurt een noodzakelijke voorwaarde is voor rechtsgebied $\mathrm{C}$, enzovoorts. Dan zou rechtsgebied A zonder meer voorrang hebben op rechtsgebied B, en zou rechtsgebied $B$ vooraf moeten gaan aan rechtsgebied $C^{529}$. Het is moeilijk om uit drie rechtsgebieden het belarigrijkste te kiezen; voor een groter aantal rechtsbegrippen is dat nog moeilijker. Het is niet uit te sluiten dat een rechtssysteem geen opvolgingskarakteristiek verschaft aan een juridisch ordeningssysteem.

Bij het bepalen van de volgorcle van classificatiebegrippen gaat het niet alleen om de keuze van het eerste begrip of rechtsgebied, want de opvolgingskarakteristiek betreft een hele reeks. Het blijkt echter problematisch om rechtsgebieden in elkaars nabijheid te brengen als ze veel eigenschappen gemeenschappelijk hebben. Het volgende voorbeeld dat is ontleend aan een juriclisch ordeningssysteem ${ }^{530}$ kan dit illustreren voor rechtsgebieden naar maatschappelijke sectoren.

\subsection{GEMENGDE ${ }^{531}$ RECHTSGEBIEDEN}
86.71 BOUWRECHT
86.72 HUURRECHT
86.73 VERVOERSRECHT
86.74 VERKEERSRECHT
86.75 MLLIEURECHT
86.76 RUIMTELIIKE-ORDENINGSRECHT
86.77 AGRARISCH RECHT

Voor deze rechtsgebieden is er geen sprake van een dwingende volgorde, bijvoorbeeld omdat het belang van de ene sector telkens groter is dan dat van een andere sector. Verwante maatschappelijke sectoren ontbreken in het geval van huurrecht (86.72) en vervoersrecht $(86.73)$. Er is geen opvolgingskarakteristiek voor alle opgesomde rechtsgebieden.

528. Cf. Loth 1987. 364

529. Cf Wan Laer 1984, 35 .

530 . Gemeenschappelijke Onderwerpsontsluiting. 119.

531. Men zou deze "gemengde" rechtsgebieden kunnen zien als "functionele" rechtsgebieden. 
Niet alleen het bepalen van de volgorde tussen rechtsgebieden is problematisch, ook binnen én rechtsgebied is een opvolgingskarakteristiek voor de ondergeschikte classificatiebegrippen met moeite te vinden. Dit kan blijken uit het volgende fragment uit een juridisch ordeningssysteem ${ }^{532}$ :

\subsection{STAATSRECHT: ALGEMEEN}

86.51 GRONDWET

86.52 GRONDRECHTEN

86.53 RECHT VAN LAGERE OVERHEDEN

86.54 STAATSRECHT: OVERIGE

De restcategorie met de notatie ' 86.54 ' doet de rubriek ' 86.50 ' volledig zijn ${ }^{533}$ maar moet buiten beschouwing blijven omdat 'staatsrecht: overige' geen rechtsbegrip is; de plaats van deze restcategorie wordt bepaald door traditie of conventie. Is overigens een opvolgingskarakteristiek ontleend aan een rechtssysteem? Aannemelijk is dat het 'recht van lagere overheden' als van lagere rang moet volgen op 'grondwet' en 'grondrechten'. Het is echter niet vanzelfsprekend dat de grondwet van hogere rang is dan de grondrechten. Hier is een andere opvolgingskarakteristiek gehanteerd: de grondwet is een rechtsbron voor het staatsrecht in het algemeen en voor de grondrechten in het bijzonder. Een opvolgingskarakteristiek met de rangorde van regelgeving als criterium is niet consequent gehanteerd in dit voorbeeld. Het bovenstaande fragment toont een volgorde die voor de constructie van een juridisch ordeningssysteem gebruikelijk is geacht ${ }^{534}$.

Rechtsstelsels verschaffen veelal geen opvolgingskarakteristiek aan juridische ordeningssystemen. Voor een hele reeks is een dwingende volgorde van classificatiebegrippen vrijwel witgesloten. Tradities of conventies voorzien in opvolgingskarakteristieken.

\section{§ 3. Rechtsvergelijkende ordeningssystemen}

\section{A. KEUZE VAN INDELINGSKARAKTERISTIEKEN}

In een rechtsvergelijkend ordeningssysteem kunnen met dezelfde notatie documenten omtrent overeenkomstige rechtsbegrippen worden teruggevonden ${ }^{535}$. Er is sprake van

532. Gemeenschappelijke Onderwerpsontsiuiting, 118.

533. Cf. Mills, 25.

534. Met het oog op de gebruikers van het ordeningssysteem die gewend zijn aan een volgorde van documenten op de planken of in de bibliotheekcatalogus: cf. Van Laer 1984, 34.

535. Zie III.\$ S.B. 
een rechtsvergelijkend ordeningssysteem indien hetzelfde classificatiebegrip verwijst naar documenten met betrekking tot meer dan éen rechtsstelsel ${ }^{536}$. Deze classificatiebegrippen zullen hierna "rechtsvergelijkende classificatiebegrippen" worden genoemd. Zij zijn opgenomen in een rechtsvergelijkend ordeningssysteem dat bestemd is voor een bibliotheekcollectie die gericht is op rechtsvergelijkend onderzoek. Van dit ordeningssysteem is geen sprake wanneer een bibliotheekcollectie documenten omtrent verschillende rechtsstelsels bevat, terwijl elk rechtsstelsel volledig volgens zijn uniciteit is ingedeeld. Deze bibliotheekcollectie is weliswaar bruikbaar voor rechtsvergelijkend onderzoek maar dit ordeningssy steem mist rechtsvergelijkende classificatiebegrippen met kenmerken gemeenschappelijk aan verschillende rechtsstelsels.

Volgens Ellinger kunnen opvolgingskarakteristieken in nationale rechtsstelsels reden zijn om elk rechtsstelsel volgens zijn uniciteit in te delen. Dit zal eerst worden besproken omdat Ellinger een grensgeval belicht waarin hij een rechtsvergelijkend ordeningssysteem onmogelijk acht. Ellinger ${ }^{537}$ onderkent de mogelijkheid dat de volgorde van rechtsbegrippen in een rechtssysteem zodanig dwingend is dat een afwijkende volgorde in een ordeningssysteem zou leiden tot aantasting van wat hij 'structurele integriteit' noemt. In het geval van een dwingende volgorde van rechtsbegrippen is er volgens Ellinger sprake van onverenigbare rechtssystemen zodat er voor elk rechtsstelsel een apart ordeningssysteem ontwikkeld zou moeten worden. Een dwingende volgorde ontbreekt indien de volgorde van classificatiebegrippen in een rechtsvergelijkend ordeningssysteem mag afwijken van die van de rechtsbegrippen in een nationaal rechtssysteem, bijwoorbeeld als de relatieve plaats van een rechtsgebied in een rechtssysteem een kwestie van voorkeur is. Dan kan een opvolgingskarakteristiek worden ontleend aan een ander rechtsstelsel met rechtsgebieden in een volgorde die niet kan worden gewijzigd zonder de structurele integriteit van dat laatste rechtssysteem aan te tasten. Ellinger geeft echter niet verder aan hoe zijn criterium van structurele integriteit een dwingende volgorde bepaalt. Hij heeft een grensgeval op het oog omdat een dwingende volgorde van rechtsgebieden zelden zal voorkomen ${ }^{538}$. Een afwijkende volgorde in twee rechtsstelsels zal veelal geen beletsel zijn voor het construeren van een rechtsvergelijkend ordeningssysteem.

536. Strikt genomen zijn er drie mogelijkheden te onderscheiden: (1) éen document vergelijkt twee of meer rechtssstelsels; (2) éến document behandelt twee of meer rechtsstelsels zonder die te vergelijken; (3) twee of meer documenten die ieder ến of meer andere rechtsstelsels behandelen, wordt één notatie toegekend:

537. C. Ellinger $1964,364$.

538. Zie IV.\&2.C. 
Een rechtsvergelijkend ordeningssysteem is opgebouwd uit een grondslag en uit indelingskarakteristieken. De grondslag is het hoogste soortbegrip ${ }^{539}$ dat voldoende algemeen moet zijn. Een mondiale dekking is het meest doelmatig tenzij een bibliotheekcollectie beperkt blijft tot documenten omtrent enkele rechtsstelsels. De indelingskarakteristieken bepalen welk soortmakend verschil toegestaan is ter specificatie van de hogere soortbegrippen. Aan deze indelingskarakteristieken worden bijzondere eisen gesteld in een rechtsvergelijkend ordeningssysteem omdat ze moeten leiden tot rechtsvergelijkende classificatiebegrippen: soortbegrippen met kenmerken die gemeenschappelijk zijn aan verschillende rechtsstelsels. Hetzelfde rechtsvergelijkende classificatiebegrip moet documenten omtrent twee of meer rechtsstelsels omvatten. De selectie van gemeenschappelijke kenmerken zal in de volgende paragraaf $(\$ 3 . \mathrm{B})$ aan de orde komen en de bepaling van de extensie van rechtsvergelijkende classificatiebegrippen in \$3.C. Hier (in \$ 3.A) gaat de aandacht verder uit naar de keuze van indelingskarakteristieken omdat zij de hoofdlijnen van het rechtsvergelijkende ordeningssysteem bepalen.

De opbouw van een juridisch ordeningssysteem moet zoveel mogelijk aansluiten bij de hiërarchische relaties tussen de rechtsbegrippen in een rechtssysteem ${ }^{540}$. Dat geldt ook voor een rechtsvergelijkend ordeningssysteem. De keuze van indelingskarakteristieken voor een rechtsvergelijkend ordeningssysteem moet de hiërarchische relaties van de rechtsvergelijkende classificatiebegrippen doen aansluiten bij de hiërarchische relaties van de verschillende rechtsstelsels. Er kan worden overwogen on met dezelfde indelingskarakteristiek alle juridische documenten zonder onderscheid in één rechtsvergelijkend ordeningssysteem in te delen. Dit ordeningssysteem is echter weinig doelmatig in het geval van uiteenlopende hiërarchische relaties in de rechtsstelsels. Dan is het doelmatig om verschillende indelingskarakteristieken te kiezen zodat de gebruiker de documenten kan terugvinden op de plaats waar hij die verwacht. Het nadeel is echter dat heterogene indelingskarakteristieken het ordeningssysteem onoverzichtelijk maken ${ }^{541}$.

Het is de vraag welke indelingskarakteristieken ertoe leiden dat rechtsvergelijkende classificatiebegrippen de documenten in het juiste verband plaatsen. Deze vraag is beantwoord voor varianten van rechtsvergelijkende ordeningssystemen die hierna geanalyseerd zullen worden ${ }^{542}$. Een ordeningssysteem kan zodanig zijn opgebouwd dat

539. Zie IV.\$1.B.

540. Zie IV.\$2.A.

541. Zie IV. 1.B.

542. Daaronder bevinden zich systemen die hoofdzakelijk voor de rechtswergelijkende documentencollectie van ëén bibliotheek zijn ontworpen maar ook systemen die alle wetenschapsgebieden omwatten en die in vele bibliotheken worden gehanteerd. 
rechtsvergelijkende classificatiebegrippen van toepassing zijn op de documenten van een beperkt aantal rechtsstelsels. Dit geldt voor de ordeningssystemen van Moys en Steiner ${ }^{543}$, Lansky ${ }^{544}$ en de Library of Congress ${ }^{545}$. Een volgende variant is dat elk rechtsstelsel een afzonderlijke hoofdklasse krijgt terwijl eên indelingskarakteristiek voorziet in een uniforme indeling op het tweede classificatieniveau. Deze variant doet zich voor bij Schiller ${ }^{346}$. Ook het ongekeerde wordt verdedigd: de Universele Decimale Classificatie ${ }^{547}$ bevat een uniforme indeling op thet eerste classificatieniveau en een indeling naar rechtsstelsel op het tweede niveau. Het is onverschillig of dezelfde indelingskarakteristiek op het eerste of het tweede classificatieniveau wordt toegepast. In beide varianten zijn rechtsvergelijkende classificatiebegrippen van toepassing op de documenten van alle rechtsstelsels. Met een uniforme indeling wordt bovendien het beginsel van eenheid van indelingskarakteristiek gehonoreerd. Dit bevordert dat het ordeningssysteem overzichtelijk is ${ }^{544}$.

Er is geen algemeen antwoord te geven op de vraag welk rechtsvergelijkend ordeningssysteem het meest doelmatig is. Hierna zal worden besproken welke argumenten zijn gelewerd voor de keuze van grondslag en indelingskarakteristieken. De grondslag en de daarbij behorende indelingskarakteristieken zullen worden onderscheiden in: de rechtsfamilie, het rechtsstelsel of het rechtsgebied ${ }^{549}$. Deze indelingskarakteristieken kunnen worden gekozen voor de eerste of de tweede trap wan een ordeningssysteem; dat is een doelmatigheidskwestie. Er gelden geen algemene normen voor de keuze van indelingskarakteristieken op het eerste of tweede classificatieniveau ${ }^{550}$. Er is geen algemene consensus ten aanzien van de hoofdlijnen van de opbouw van rechtsvergelijkende ordeningssystemen.

Rechtsvergelijkende ordeningssystemen bevatten rechtsvergelijkende classificatiebegrippen die verwijzen naar documenten met betrekking tot meer dan één rechtsstelsel. Dit geldt ongeacht de keuze en de volgorde van indelingskarakteristieken. Rechtsvergelijkende classificatiebegrippen bestaan uit kenmerken die gemeenschappelijk zijn aan verschillende rechtsstelsels. Daarom zal in $\$ 3$. B worden ingegaan op de selectie van gemeen-

543. Zie IV. 4.A.

544. Zie IV. \$4.B.

545. Zie IV.\$5.A, IV.\$5.B en IV.\$5.C.

546. Zie IV.\$3.B.

547. Zie IV.8 4.A.

548. Zie IV. $11 . \mathrm{B}$.

549. Zie IV.84.A, IV. 4. B en IV.8 4.C.

550. Een inventarisatie van ordeningssystemen in gebruik bij Duitse bibliothelken heeft tot deze conclusie geleid: Kreuzer, 148; of. 141-142. 
schappelijke kenmerken voor rechtsvergelijkende classificatiebegrippen. Een rechtsvergelijkend classificatiebegrip omvat documenten van meer rechtsstelsels. Daarom wordt (in \& 3.C) de extensie van rechtsvergelijkende classificatiebegrippen behandeld.

\section{B. SELECTIE VAN GEMEENSCHAPPELIJKE KENMERKEN}

Classificatiebegrippen in een rechtsvergelijkend ordeningssysteem bevatten kenmerken voor documenten met gemeenschappelijke eigenschappen. Bij de selectie wan de kenmerken voor rechtsvergelijkende classificatiebegrippen moet rekening gehouden worden met de hiërarchische relaties van de verschillende rechtsstelsels ${ }^{551}$. De plaats van het rechtsbegrip in zijn rechtssysteem is een belangrijk ervaringsgegeven bij het klasseren van documenten met behulp van één notatie. Als de grondslag van de begripsindeling verschilt, ontbreken er gemeenschappelijke eigenschappen zodat het ondoelmatig is dezelfde notatie toe te kennen aan de betreffende documenten. Er kunnen bijvoorbeeld geen gemeenschappelijke kenmerken geselecteerd worden voor de Engelse 'real mortgage' en de Franse 'hypothèque', of voor de Engelse 'chattel mortgage' en de Franse "hypothèque mobilière" 552 .

In het rechtsvergelijkende ordeningssysteem van Schiller worden de hiërarchische relaties van het rechtsbegrip verwaarloosd. Hij postuleert dat er tussen de materie in de verschillende rechtssystemen conformiteit aanwezig is ${ }^{553}$. Nadat hij zijn ordeningssysteem op de eerste trap heeft ingedeeld naar rechtsstelsels, verdeelt hij elk rechtssysteem op de tweede trap naar materie met gebruik van identieke getallen voor elk rechtssysteem ${ }^{554}$.Zo veronderstelt Schiller dat bijzondere overeenkomsten zoals koop en ruil in vrijwel alle rechtssystemen conformiteit vertonen zodat eenzelfde notatie kan worden toegekend ${ }^{555}$. Hij is echter bedacht op uitzonderingen: voor de Nederlandse 'vaststellingsovereenkomst' geeft hij ${ }^{556}$ aan dat deze slechts in het Nederlandse rechtsstelsel voorkomt ${ }^{557}$. De notatie 541 voor de Nederlandse vaststellingsovereenkomst is geen rechtswergelijkend classificatiebegrip. Daarentegen is 'Property - Cooperative housing' met de notatie $413^{558}$ een rechtsvergelijkend classificatiebegrip dat op alle apparte-

551. Zie IV. 3.A.

552. Zie III. 3.B.

553. Schiller $1964,13,19$.

554. Szladits, 579, ziet en en ander als een groot woordeel woor de onderzoeker.

555. Schiller 1964, 15, 38 .

556. Schiller 1964, 19, 38 .

557. De opvatting van Schiller dat de vaststellingsovereenkomst uniek is voor Nederland, is een interpretatiekwestie: zie III. 2.A.

558. Schiller 1964,35 . 
mentsrechten van toepassing is. Ofschoon de hiërarchische relaties van dit rechtsbegrip aanleiding geven tot een heterogene indelingskarakteristiek ${ }^{559}$ verkiest Schiller een uniforme indelingskarakteristiek voor het tweede classificatieniveau. Daardoor is zijn ordeningssysteem overzichtelijk ${ }^{560}$. Zijn ordeningssysteem is echter ondoelmatig waar gemeenschappelijke eigenschappen van documenten ontbreken: de notatie 435 voor 'Property - Mortgage' ${ }^{561} \mathrm{kan}$ niet worden toegekend aan documenten omtrent de Franse 'hypothèque'. Aan de selectie van gemeenschappelijke kenmerken voor een rechtsvergelijkend classificatiebegrip dient een onderzoek vooraf te gaan naar de rechtsbegrippen in hun rechtsstelsels.

\section{DE EXTENSIE VAN RECHTSVERGELIKENDE CLASSIFICATIEBEGRIPPEN}

Op welke documenten een rechtswergelijkend classificatiebegrip van toepassing is, wordt bepaald door zijn intensie ${ }^{562}$. De extensie van een classificatiebegrip bestaat uit de documenten die tot de klasse behoren. De rubrieksomschrijving is slechts een hulpmiddel $^{563}$ voor het toepassen van het classificatiebegrip. De rubrieksomschrijving kan de extensie van rechtsvergelijkende classificatiebegrippen helpen bepalen ${ }^{564}$. In de rubrieksomschrijving kan worden opgesomd welke rechtsstelsels behoren tot de extensie van het classificatiebegrip. Zo vermeldt Schiller ${ }^{565}$ bij het getal ${ }^{566} 550$ naast 'Contracts - Mandate': 'Auftrag' voor Duitsland en 'Lastgeving' voor Nederland. Dit is geen limitatieve opsomming maar een illustratie van toepassingsmogelijkheden van dezelfde notatie.

De extensie van een rechtsvergelijkend classificatiebegrip kan afhankelijk worden gesteld van de gebruikersgroep waarvoor het ordeningssysteem is bestemd. Dit wordt toegelicht door Ellinger ${ }^{567}$. Hij ontwikkelt zijn standpunt vanuit de common law. Volgens Ellinger is her mogelijk dat het buitenlandse recht wordt ingedeeld met categorieền van de common law indien het ordeningssysteem is bestemd voor praktijkjuristen en een kleine collectie. Dit leidt volgens hem tot 'assimilatie' van onderwerpen van

559. Zie IV. 2.B

560, Zile IV. 1.B.

561. Schiller 1964, 35

562. De intensie bepalti de extensie: zie III. 2.A.

563. Zie IV.\$2.A.

564. Cf. Ellinger 1964, 364-365.

565. Sehiller 1964, 38.

566. Deze notatie is neutraal ten opzichte van rubrieksonuschrijvingen in verschilhende talen: cf. Gödert, 161. Zie V. 4.A voor het gebrik van notaties in meertalige thesauri.

567. Elllinger $1962,380-381$. 
buitenlands recht aan verwante onderwerpen van Anglo-Amerikaans recht. Deze assimilatie is volgens Ellinger uitvoerbaar indien de hièrarchische relaties van het buitenlandse rechtssysteem buiten beschouwing blijven door de indeling te beperken tot rechtsgebieden zoals auteursrecht of strafrecht, ofwel tot groepen van onderwerpen zoals inkomstenbelasting of kiesrecht. Ellinger veronderstelt dat het voor praktijkjuristen die een kleine collectie raadplegen geen bezwaar is dat de extensie van een klasse voor de common law ook documenten van een andere rechtsfamilie omvat. Deze assimilatie is volgens Ellinger ondoelmatig in het geval van een grote bibliotheekcollectie die is bestemd voor wetenschappelijk onderzoek; dan moet het onderwerp in de juridische omgeving van zijn rechtssysteem en zijn rechtsliteratuur aangetroffen kunnen worden. Omdat de hiërarchische relaties in de common law verschillen van die in de civil law, is differentiatie naar rechtsfamilies doelmatig voor wetenschappelijke onderzoekers.

Op pogingen om Anglo-Amerikaanse rechtsliteratuur te forceren in begrippen van de civil law heeft Ellinger ${ }^{568}$ de volgende kritiek: deze pogingen leiden ertoe dat onderwerpen die gewoonlijk in elkaars context worden behandeld, worden geseheiden terwijl onderwerpen met elkaar in verband worden gebracht die in het algemeen niet worden gecombineerd. Vanuit de behoeften van de Amerikaanse praktijkjurist is het volgens Ellinger onaanvaardbaar om Anglo-Amerikaanse rechtsliteratuur binnen de extensie van classificatiebegrippen van de civil law te brengen. Voor dezelfde doelgroep van praktijkjuristen bleek het echter geen bezwaar te zijn om onderwerpen van buitenlands recht in te delen met classificatiebegrippen van de common law. Ook ${ }^{569}$ hier is het gemak van de gebruiker een willekeurig criterium.

\section{\$. Indelingskarakteristieken in rechtsvergelijkende systemen}

\section{A. DE RECHTSFAMILIE}

De grondslagen en bijbehorende indelingskarakteristieken voor rechtsvergelijkende ordeningssystemen worden onderscheiden in: de rechtsfamilie $(\$ 4 . A)$, het rechtsstelsel $(\$ 4 . B)$ en het rechtsgebied $(\$ 4 . C)$.

Het is de vraag of indelingskarakteristieken voor rechtsfamilies nodig zijn. Er is een ordeningssysteem dat geen onderscheid maakt naar rechtsfamillies: de Universele Decimale Classificatie. De Universele Decimale Classificatie beoogt een mondiale dekking. Dit ordeningssysteem is ontworpen vanuit een rechtsvergelijkend geziclitspunt en is

568. Ellinger 1956, 456 .

569. Zie IV.\& 2.A. 
gebaseerd op begrippen die in beginsel dezelfde zouden zijn in de verschillende landen, ofschoon ze soms zeer verschillende namen dragen ${ }^{570}$. Deze universalistische pretentie wordt echter bestreden. Zo meent Nagy ${ }^{571}$ dat de Universele Decimale Classificatie minder geschikt is voor de islamitische rechtsfamilie, de rechtsstelsels van het verre Oosten en die in sommige ontwikkelingslanden. Verder beweert Korevaar ${ }^{572}$ dat common law-iteratuur slechts met moeite is in te delen omdat de Universele Decimale Classificatie het continentale West-Europese recht weerspiegelt. Uit deze kritiek blijkt dat het problematisch is om een indelingskarakteristiek voor rechtsfamilies achterwege te laten. Het differentiëren van een rechtsvergelijkend ordeningssysteem naar rechtsfamilies is echter evenmin zonder problemen.

Degene die een rechtsvergelijkend ordeningssysteem wil differentiëren naar rechtsfamilies wordt geconfronteerd met het probleern de rechtsfamilies af te bakenen om de rechtsstelsels te groeperen naar rechtsfamillies. Er kan geen aansluiting worden gezocht bij een heersende opvatting in de rechtsvergelijking omdat een consensus omtrent de indeling van rechtsstelsels naar rechtsfamilies ontbreekt ${ }^{573}$. Er zijn diverse criteria voor de groepering van rechtsstelsels: geografisch, bijvoorbeeld Latijns-Amerika; politick, bijvoorbeeld EG-lidstaten; naar taaleenheil, bijvoorbeeld Arabische staten; of naar thema's in de literatuur, bijvoorbeeld ontwikkelingslanden ${ }^{574}$.

Ten aanzien wan het geografische criterium is omstreden welke kenmerken moeten voorzien in een geschikte indelingskarakteristiek voor rechtsfamilies. $\mathrm{Er}$ is voorgesteld ${ }^{535}$ om rechtsstelsels naar continenten te groeperen om veroudering van de groepering te voorkomen en de afbakening te vergemakkelijken. Dit voorstel komt echter niet tegemoet aan de verschillen tussen rechtsstelsels binnen hetzelfde geografische gebied ${ }^{57 \%}$ : het rechisstelsel van Griekenland bijvoorbeeld kan niet als Oost-Europees worden beschouwd. Een continent Afrika zou minstens vier grote rechtsstelsels omvat-

570. Lă Fontu ine (zonder paginèring) Droit, législation, jurisprudence. Observations générales, $\mathrm{A}$.

571. Nagy, 31.

572. Korevaar 1974, 20: cf. Groll 1974t, 30. Cf. Moys 1976, 562: de juridische klasse van de Universele Decimate Classificatio is in hoofdzak door continentale documental isten ontwikkeld.

573. Kokkini 1985, 9; of. Hall, 94

574. Steiner $1981,120-121$. Overigens is het criterium wan ontwikkelingslanden problematisch ondlat niet eetududig is welke staten op een zeker monient tot de ontwikkelingslanden moeten worden gerekend; aldus: Lansky 1981, XVII.

575. Kreuzer, 152. Lunsky 1968,9 10, prefereert een indeling van het buitenlandse recht naar continenten in plaats van nar rechtsfamilies, ondat de eerste indeling minder twijfelachtig en meer uniform naar rechtsstof en periode zou zijn.

576. Stepan, 564. In dezelfde geografische regio kunnen rechtsstelsels niettemin vergelijkbaar zijn ondat de matatschappijstructuren elkwar weinig ontlopen: De Boer 1.992, 47. 
ten. Een regio verre Oosten zou zowel het communistische Chinese recht als het kapitalistische Japanse recht bevatten. Een puur geografisch criterium doet dan ook geen recht aan de eigen aard van rechtsstelsels. Een niet-geografische indeling in rechtsfamilies dient echter rekening te houden met de ontwikkeling van rechtssystemen en is tijdgebonden ${ }^{57}$.

Een rechtsvergelijkend ordeningssysteem met een heterogene indeling van rechtssystemen is dat van Moys ${ }^{578}$ : zij scheidt de common law van de andere modeme rechtssystemen door de common law onder te brengen in de hoofdklassen KF tot en met KN; en de overige moderne rechtsstelsels in de hoofdklassen $\mathrm{KR}$ tot en met $\mathrm{KV}$ voor respectievelijk Afrika, Latijns-Amerika, Azië en de Stille Zuidzee, en Europa ${ }^{579}$. Moys brengt een dichotomie aan tussen de rechtsstelsels die tot de common law behoren en die niet daartoe behoren; waar deze hoofdklassen elkaar uitsluiten, is haar ordeningssysteem volledig ${ }^{580}$. De vertakking van de common law wordt echter volgens een andere indelingskarakteristiek gespecificeerd dan de tweede vertakking. De common law wordt beperkt tot de rechtsstelsels van Engeland en Wales, Canada, Australie, Nieuw-Zeeland en de Verenigde Staten ${ }^{581}$ omdat deze rechtsstelsels volgens Moys geheel of nagenoeg geheel op de common law gebaseerd zijn ${ }^{582}$. Gemengde rechtssystemen zoals die van India ${ }^{583}$ of Nigeria ${ }^{584}$, die niet alleen common law bevatten, worden niet tot de common law gerekend omdat ze verwacht dat deze rechtssystemen zich van de common law zullen verwijderen ${ }^{585}$.

Volgens Moys wordt de kern van de rechtssystemen van de common law veelal als homogeen beschouwd ofschoon er lokale detailverschillen zijn. Vanwege een kruisbe-

577. Op de tijdgebondenheid van de indeling in rechtsfamilies wijxen De Groot $1988 \mathrm{a}, 8$ en Kokkini $1988 \mathrm{a}$, 86.

578. Moys 1992. De belangrijkste actualisering wan de tweede druk (Moys 1982) ten opzichte wan de eerste druk (Moys 1968) bestal uit de toevoeging van een compleet nieuwe indeling voor EG-recht; aldus Moys, 1982, 5. Dit zal samenhangen met het EG-lidmatatschap van Groot-Brittannie.

579. Moys 1992, xxiv-xxv. De hoofdklasse KD is gereserveend voor religieuze rechtsstelsels. De hoofdklasse KU ontbreekt.

580. Cf. Engisch 1973, 143.

581. Birch, 787 ; ef. Moys 1992, xii, xxiv.

582. Moys 1968, 8; Moys 1992, xii.

583. Met de notatie "KT 1501" ingedeelld in Azie: Moys $1992,147$.

584. Met de notatie 'KR 1401' ingedeeld in Afrika: Moys 1992, 142.

585. Moys, 1968, 8-9: buiten de common law in enge zin vallen ook rechtsstelsels zoals die van Schotland, Quebec of Louisiana die be invloed zijn door de common law maar hun diarvan onderscheiden rechtsstelsel hebben behouden; deze categorie wordt bij voorkeur niet gescheiden van, maar onderscheiden binnen de common law. 
stuiving in de jurisprudentie behandelt ze de landen waarvan de rechtsstelsels vrijwel geheel op de common law zijn gebaseerd, als dellen van één rechtssysteem naast alle overige rechtssystemen ${ }^{3}$. Op grond van juridische criteria reduceert Moys de centrale common law tot enkele rechtsstelsels die daartoe strikt genomen behoren ${ }^{587}$; deze rechtsstelsels worden zonder onderscheid ingedeeld in de hoofdklassen KL voor algemene onderwerpen, $\mathrm{KM}$ voor publiekrecht en $\mathrm{KN}$ voor privaatrecht ${ }^{588}$. Moys beschouwt de rechtsstelsels van Engeland en Wales, Canada, Australië, Nieuw-Zeeland en de Verenigde Staten als een eenheid. De andere rechtsfamilies Afrika, Latijns-Amerika, Azjề en de Stille Zuidzee, en Europa zijn een restcategorie; zij komen met een geografi sche indelingskarakteristiek tot stand. Deze indeling in rechtsfamilies is mede afhankelijk van het doel van het rechtsvergelijkende ordeningssysteem: Moys geeft toe dat haar ordeningssysteem een duidelijke vertekening vertoont in de richting van de common law $^{589}$.

De volgende indeling van rechtssystemen in rechtsfamilies is aanwezig in het ordeningssysteem van Steiner voor de Squire Law Library van de universiteit van Cambridge $^{590}$. Evenals Moys maakt Steiner op het niveau van de rechtsfamilies een onderscheid tussen de common law-rechtsstelsels en wat hij noemt: de 'non-common law"rechtsstelsels. Tot de common law-rechtsstelsels rekent hij onder meer: het Verenigd Koninkrijk, Canada, Australië, Nieuw-Zeeland, Zuid-Afrika, Maleisië, India en de Verenigde Staten ${ }^{591}$. Het Schotse recht wordt niet bij het Engelse recht ingedeeld ${ }^{592}$. Daarentegen worden verhandelingen die voortkomen uit common law-rechtsstelsels en die onderwerpen van common law in het algemeen behandelen, bij het Engelse recht ingedeeld ondat ze daarvoor relevant $z^{i j n}{ }^{593}$. Dit hangt waarschijnlijk samen met de aard van de collectie van de Squire Law Library: Engels recht vormt de kern daarvan ${ }^{594}$ en Steiner beperkt zich tot de bezoekers van de collectie van de Squire Law Library in het Engellse Cambridge ${ }^{595}$. Deze collectie en deze doelgroep heeft

586. Moys 1982, 12: Moys 1992, xii.

587. Het primaire bronnenmaterial van Engeland, Wales en de Verenigde Staten wordt apart ingedeeld: Moys 1992, xii, xix. Voor dit primaire materiaal zijn de hoofdklassen KF, KG en KH bestemd. Overigeng vatriëren de criteria voor primair materiaal per rechtsstelsel: Moys 1968, 12.

588. Moys 1992 , xxiv- $x \times y$.

589. Moys 1968, 19; of Korewar 1968, 18.

590. Steiner 1974b. Dit ordeningssysteem was in 1991 nog in gebruik: Steiner 1991, 286.

591. MoVeigh, 49.

592. Steiner $1974 b, 7,70$.

593. Steiner $1974 b, 70$.

594. McVeigh, 49.

595. Steiner 1974b, 5 . 
Steiner in zijn overwegingen betrokken om te komen tot een doelmatig ordeningssysteem. De heterogene indelingskarakteristiek voor rechtsfamilies doet echter afbreuk aan de overzichtelijkheid.

De keuze van een indelingskarakteristiek voor rechtsfamilies blijkt problematisch: deze indeling is tijdgebonden tenzij geografische criteria consequent worden toegepast. Het is mede afhankelijk van het gebruikersgemak welke rechtsstelsels tot een rechtsfamilie behoren. In de volgende paragraaf komt aan de orde welke moeilijkheden de indelingskarakteristiek voor rechtsstelsels oplevert.

\section{B. HET RECHTSSTELSEL}

Een indelingskarakteristiek voor rechtsstelsels ontmoet twee problemen: de tijdgebondenheid van rechtsstelsels; en de indeling van gelijksoortige rechtsstelsels in subgroepen. Een indelingskarakteristiek naar rechtsstelsels kan op elke trap van een rechtsvergelijkend ordeningssysteem voorkomen. Deze keuze is afhankelijk van doelmatigheidsoverwegingen. Veelal wordt de voorkeur gegeven aan een indeling naar rechtsstelsels op het eerste classificatieniveau ${ }^{596}$.

De doelmatigheid van de presentatie bepaalt wat men tot een rechtssysteem rekent ${ }^{597}$. Het is ondoelmatig om voor elke momentopname een ander rechtsstelsel aanwezig te achten, ook al is bijvoorbeeld het Franse rechtsstelsel een opeenvolging van meer rechtsstelsels die zich op een ondeelbaar moment woordoen ${ }^{598}$. Men kan een rechtsstelsel ongewijzigd achten zolang dezelfde grondwet ${ }^{599}$ of dezelfde wetgevende en rechterlijke macht ${ }^{600}$ bestaan. Steiner ${ }^{60 l}$ hanteert dit laatste criterium omdat het preciezer is dan een politiek criterium. Het probleem is voorts dat staten geannexeerd

596. Kreuzer, 142; Steiner 1973a, 15. Cf. Pierard, 837, 843, ten aanzien wan een bibliotheek uitsluitend bestemd voor rechtsvergelijkend onderzoek. Soms gat voor de eerste trap de voorkeur uit naar een indeling in rechtsgebieden: aldus Gödan 1991,8485 , ten aanzien wan rechtsvergelijkende bibliografieen. Ct. Daly, 94.

597. Eckhoff/Sundby, 176 .

598. Alchourron/Bulygin, 89.

599. Cf. Eckhoff/Sundby, 189\%190.

600. Cf. Eckhoff/Sundby, 25.

601. Steiner 1974b, 5. Daarbij merkt hij op dat dit criterium geen uitkomst biedt in het geval van rechtssystemen zoals het Romeinse recht of het internationale publiekrecht. Het intemationale publiekrecht valt buiten het kader van dit proefschrift: zie hoofdstuk L. Moys 1968, 3, ziet het Romeinse recht als een niet-nationaal rechissysteem dat niet samenvalt met de moderne nationale grenzen. Ook dit is een restcategorie die verder buiten beschouwing blift. Datzelfde geldt voor descriptieve wetenschappen zoals criminologie; cf. Van Laer 1982, 152.154; cf. Moys 1992, xiii. 
of juist onafhankelijk kunnen worden. Er kan dan worden verlangd dat de onafhankelijkheid van de staat algemeen wordt erkend ${ }^{602}$. De vervulling van dit criterium is echter tijdgebonden. In het geval van koloniale staten is er geen afzonderlijk rechtsstelsel; de juridische documenten omtrent de kolonie worden bij het moederland geklasseerd ${ }^{603}$. Zodra de kolonie onafhankelijk is geworden, worden de juridische documenten uit de koloniale periode niet meer bij het moederland geklasseerd " maar bij de inmiddels zelf'standige staat ${ }^{604}$. Deze staat kan worden beschouwd als de opvolgende staat ${ }^{605}$ ten opzichte van de voormalige kolonie.

Een indelingskarakteristiek voor rechtsstelsels kan leiden tot een dichotomie waarbij hetzelfde kenmerk in de ene vertakking aanwezig is en in de andere vertakking niet. Een voorbeeld van een dergelijk ordeningssysteem is dat van Lansky ${ }^{606}$ die een principiële scheiding aanbrengt tussen het Duitse recht en dat van buitenlandse staten. Het nationale recht staat centraal in het ordeningssysteem van Lansky. Aannemelijk is dat deze dichotomie is atingebracht met het oog op de herkenbaarheid van de documenten omtrent het Duitse rechtsstelsel ten behoeve van Duitse bibliotheekbezoekers. Een dergelijke indeling verhindert echter dat het Duitse recht bij gelijksoortige rechtsstelsels wordt ingedeeld.

Een andere opvatting is die van Steiner. Steiner brengt gelijksoortige rechtsstelsels zoveel mogelijk bijeen ${ }^{607}$ in een subgroep. Dit wordt in zijn ordeningssysteem zichtbaar gemaakt met een expressieve notatie ${ }^{608}$. Deze notatie toont een hiërarchische ordening van rechtssystemen, bijvoorbeeld Maleisië (P), de in een federatie verbonden Maleisische staten (PE) en de deelstaat Pahang (PED) ${ }^{609}$. Behalve een federatief verband hanteert Steiner nog andere criteria voor subgroepen van gelijksoortige rechtsstelsels zoals de afsplitsing van hetzelfde grotere rechtsstelsel en het delen van een hogere rechterlijke instantie ${ }^{\text {tio. }}$.

602. Cf. Lansky 1968,12 noot $26 a$ ten aanzien var Rhodesiê.

603. Sehiller 1948, 271: als uitvloeisel dartrwan is Nederlands-Indie deel van de Nederlandse collectie.

604. Lansky 1968, 10 en noot 22 . Schiller 1964,6 , staat in dit verband een gedeeltelijk opnieuw klasseren voor.

605. Cf. Steiner $1974 \mathrm{~b}, 6$ : opvolgende staten worden niet gescheiden van hun voorgangers; daarom worden Palestina en lsrä̌l als és rech resstelsel behandeld.

606. Lansky 1968,9 .

607. Sueiner 1991; 287 .

608. Zie IV \$2.A.

609. Steiner 1974b, 6-7; cf. Moys 1992, 149.

610. Steiner 1974b, 6 . 


\section{HET RECHTSGEBIED}

Een rechtsvergelijkend ordeningssysteem bevat meestal een indelingskarakteristiek voor rechtsgebieden en daaraan ondergeschikte rechtsbegrippen. Hier gelden andere criteria voor de indeling in rechtsgebieden dan in het geval van een ordeningssysteem voor documenten omtrent één rechtsstelsel. Zo kan het aanbeveling vèrdienen om voor rechtsvergelijkend onderzoek het onderscheid tussen privaatrecht en publiekrecht achterwege te laten ${ }^{611}$. Rechtsgebieden zoals arbeidsrecht en sociaal recht enerzijds en handelsrecht en economisch recht ${ }^{6.2}$ anderzijds, zouden in hechte samenhang ingedeeld moeten worden ${ }^{613}$. Een indelingskarakteristiek voor rechtsgebieden moet op meer dan één rechtsstelsel toegepast kunnen worden.

Een rechtsvergelijkend ordeningssysteem met een homogene indelingskarakteristiek voor rechtsgebieden staat op gespannen voet met de diversiteit van nationale begrippenstelsels. Ter oplossing van dit probleem stelt Kreuzer ${ }^{6 / 4}$ een ${ }^{3}$ systemfreie problemorientierte Klassifikation' voor waarin specifieke, nationale rechtstermen worden vermeden. Hij prefereert generieke, neutrale aanduidingen op grond van dezelfde of analoge zakelijke problemen, bijvoorbeeld 'huwelijkssluitingsgebreken'. Dergelijke classificatiebegrippen zijn ondergeschikt aan vertrouwde rechtsgebieden zoals familierecht. Dit rechtsvergelijkend ordeningssysteem is volgens Kreuzer op alle rechtsstelsels van toepassing. Het nadeel van een probleemgeoriënteerde specificatie van rechtsgebieden is echter dat juridische documenten verspreid worden over de externe problemen waarop ze betrekking hebben.

611. Cf. Zweigert/Puttarken 1978, 418. Overigens onderstreept Moys 1968, 15, dat het onderscheid tussen publiekrecht en privaatrecht in de civil law veel duidelijker is dan in de common law. Toch heeft Godan 1992, 336, kritiek op het ordeningssysteem van de Library of Congress voor civil law dat is gebaseerd op de traditionele dichotomie van publiekrecht en privaatrecht zodat handelsrecht en economisch recht gescheiden worden. Voor genoemd ordeningssysteem bevestigt Goldberg 1986, 342, de algemene dichotomie van publiekrecht en priwatrecht. Deze dichotomie ontbreekt echter in de KK. klasse voor Duits recht: Goldberg $1981 \mathrm{a}_{n}$ 61; Goldberg $1981 \mathrm{c}_{\mathrm{x}} 624$.

612. Steiner 1982,321 , meent dat er sprake is van een 'interactie' tussen handelsrecht en econonisch recht. Cf. David 1992,71 .

613. Gödan 1991, 87, ten aanzien van rechtsvergelijkende bibliografieën.

614. Kreuzer, 145. Hij schrijft tot deze opvatting te zijn gekomen dankzij de moderne functionele rechisvergelijkende methode. 
Steiner ${ }^{6 i 5}$ wenst geen consequent doorgevoerde probleemgeoriënteerde specificatie van rechtsgebieden. Volgens Steiner ${ }^{616}$ kleven er bezwaren aan een eenzijdige benaderitng. Zowel juridische begrippen als thema's met juridische aspecten zijn volgens hem noodzakelijk voor de interne consistentie van een ordeningssysteem. Als een ordeningssysteen uitsluitend wordt gebaseerd op thema's en situaties met voorbijgaan aan juridische begrippen of de aard van rechtsregels, ontstaan er volgens Steiner moeilijkheden bij de juridische documenten die rechtsbegrippen zoals 'overeenkomstenrecht' behandelen. Een grondslag uitsluitend bestaande uit rechtsbegrippen acht hij ook problematisch omdat veel thema's onderworpen zijn aan rechtsregels uit verschillende rechtsgebieden. Voor milieubescherming bijwoorbeeld is zowel het bestuursrecht als het volkenrecht van belang: dit onderwerp overschrijdt de grenslijnen tussen verschillende rechtsgebieden. Volgens Steiner ${ }^{613}$ is een oplossing dat verschillende aspecten van thema's worden ingedeeld bij de relevante begrippen. Deze oplossing impliceert bijvoorbeeld dat de publiekrechtelijke regelgeving omtrent het transport ondergeschikt is aan het bestuursrecht, en dat het vervoerscontract ondergeschikt is aan het privaat- of handelsrecht ${ }^{518}$. Deze indelingskarakteristiek gaat niet voorbij aan rechtsbegrippen of de aard van rechtsregels. Steiner komt tot een soortgelijk compromis als de probleemgeoriënteerde specificatie van rechtsgebieden wan Kreuzer. Kreuzers 'systemfreie problemorientierte Klassifikation berust immers niet alleen op sociale problemen, maar ook op vertrouwde rechtsgebieden. Dergelijke ordeningssystemen gaan volgens Ellinger ${ }^{619}$ echter gepaard met de nadelen van segregatie en onduidelijkheid.

In $\$ 5$ komt het ordeningssysteem van de Library of Congress aan de orde. Dit systeem is gebaseerd op verschillende grondslagen. Eerst volgt een toelichting op de ontwikkeling van dit belangrijke rechtsvergelijkende ordeningssysteem.

615. Steiner 1981, 117 , ziet de indeling natar rechtsgebiedenals een wezenlijk probleem gelet op de verschillen iussen de rechtsstelsels.

616. Cf. Steiner 1982, 320-321.

617. Steiner 1982,321 .

618. Dat er niet steeds dezelfde keuze wordt gemaakt, zal samenhangen met het onnauwkeurige onderscheid tussen "priwatrecht" en "handelsrecht': Stepan, 569 noot 29. Overigens is bedoeld onderscheid in de chill law veetal duidelijker dan in de common law: Steiner $1977,860$.

619. Cf. Ellinger 1949, 84. Bovendien leidt een niet consequent doorgevoerde indeling van het recht bij het gerelateerde thems tot een onevenwichtige classificatie: als het auteursrecht op muziek wordt geklasseerd bij muxiek, zou het auteursrecht op kunst of literatuur bij die toepassingen ingedeeld moeten worden: Ellinger 1949, 90 noot 37. 


\section{$\S 5$. Het systeem van de Library of Congress Classification}

\section{A. HET INDIVIDUELE RECHTSSTELSEL ALS VERTREKPUNT}

Het ordeningssysteem van de Library of Congress (LCC) is de meest gedetailleerde classificatie van diverse rechtssystemen. Dit ordeningssysteem geeft blijk van een genuanceerde tussenpositie: het heeft niet de universalistische pretentie van de Universele Decimale Classificatie ${ }^{620}$ maar het bevat ook geen classificatie voor elk rechtssysteem afzonderlijk. Dit rechtvaardigt een uitvoerige bespreking van thet juridische ordeningssysteem van de Library of Congress. De overige ordeningssystemen van de LCC, die alle menselijke kennis poogt te omvatten ${ }^{621}$, blijven hierna buiten beschouwing.

Uit de geschiedenis van de LCC blijkt dat het vertrekpunt bij de constructie van de juridische ordeningssystemen individualiserend is geweest: voor elk rechtssysteem zou een eigen ordeningssysteem worden ontwikkeld. Men wilde geen begrippen of terminologie opleggen aan een ander rechtsstelsel dan waarvoor ze geldig zijn ${ }^{622}$. Daarom werd aanvankelijk voor het rechtsstelsel als grondslag gekozen. De bijzondere begrippen en begripsrelaties van elk rechtsstelsel moesten opgenomen worden in een systematische, hiërarchische orde ${ }^{623}$. Toch is de hiërarchie van het eerste juridische ordeningssysteem van de LCC, dat voor het recht van de Verenigde Staten ${ }^{624}$, niet absoluut. Daarin ontbreekt een hiërarchische piramide van rechtsbegrippen of rechtsregels met 'recht' aan de top; het hoogste classificatieniveau bestaat uit nevengeschikte rechtsgebieden. Bovendien zijn de rechtsgebieden in het ordeningssysteem voor de Verenigde Staten niet hiërarchisch onderverdeeld indien de juridische literatuur van een strikte hiërarchie afwijkt door de combinatie van een aantal onderwerpen tot één heterogeen onderwerpsgebied ${ }^{625}$. Het ordenen van juridische documenten in de open opstelling yan één bibliotheek staat voorop. Ook voor de latere juridische ordeningssystemen van

620. Zie IV. 8 4.A.

621. In die zin is de LCC universeel: cf. Evans, 35-36; cf. Groeneveld, 225 ,

622. Goldberg 1986, 334 .

623. Goldberg 1981c, 620 .

624. Goldberg $1981 \mathrm{c}, 620$.

625. Cf. Ellinger 1968, 229: 'collecting of accounts' bevat elementen van verschillende rechtsgebieden. 
de LCC is rekening gehouden met de uitgebreide collecties van de Library of Congress $^{626}$.

In een vroeg stadium van de ontwikkeling van de juridische ordeningssystemen van de LCC werd begrepen dat niet elk rechtsstelsel een volledig ontwikkeld ordeningssysteem zou vergen ${ }^{627}$. Tevens werd de gebruikelijke groepering van rechtsstelsels in common law, civil law en socialistisch recht verlaten ten gunste van een geografische ordening naar continenten als een relatief stabiele ordening die minder onderhevig zou zijn aan politieke veranderingen ${ }^{62 \%}$. Het werd bovendien mogelijk geacht om modelclassificaties te ontwikkelen op de grondslag van een regio ${ }^{629}$. Er werden modelclassificaties geconstrueerd voor exemplarische rechtsstelsels ${ }^{630}$ : rechtsstelsels die, zoals het Duitse rechtsstelsel, exemplarisch zijn voor een regio. Een regio is kleiner dan een continent en is te beschouwen als een subgroep binnen een rechtsfamilie. Een regio is niet zuiver geografisch zoals een continent. Dit blijkt uit de complexe definitie van een regio: een geografisch bepaald gebied waarin (1) historische, religieuze en heersende sociaaleconomische of etnische gelijkenissen - zoals weerspiegeld in de regelgeving en de verdragen geproduceerd in dat gebied - toestaan dat specifieke indelingen worden toegepast op een veelheid van rechtssystemen; en waarin (2) culturele, wetenschappelijke en economische belangen hebben geleid tot regionale integratie en regionale organisaties in verschillende vormen. Regionale ordeningssystemen zijn het resultaat van rechtsvergelijkend onderzoek dat het algemene substraat van begrippen bepaalt met identificatie

626. Cf. Angell, 353-354. Deze collecties bepaalden de prioriteiten voor de ontwikkeling van de juridische ordeningssystemen. De beslissing voor welk recthtsstelsel een ordeningesysteem wolledig ontwikkeld moest worden, was primair afhankelijk wan de omvang van de deelcollecties van de Library of Congress en vervolgens van de complexiteit wan het onderwerpsgebied zoals dat in monografieen was behandicld: Goldberg 19810,620 .

627. Goldberig 1986, 335 .

628. Goldberg 1986, 335; cf. Goldberg 1981c, 620 .

629. Cr. Goldberg 1987, 67, 70: met de KDZ, KG, KH-klasse voor Midden-en Zuid-Amerika is de nieuwe generatie van vergelijkende of regionale ondeningssystemen begonnen. Daarop is de KJ-KKZ-klasse voor Europa gevolgd: Goldberg 1987, 68-69. Destijds stonden ordeningssy stemen voor de Sovjet-Unie, Azis, Afrika respectievelijk Australie op het programma: Goldberg 1987,71 noot 21, 91. Zie inmiddels: Goldberg 1993. Hiermee is het juridische ordeningssysteem van de LCC voltooid: Daly, 92; Goldberg 1994, 347. Een gedetailleerd overzicht van de juridische klassen van de LCC is te vinden bij Chan, 192-197; het defmitieve overzicht bij Daly, 95-96.

630. Cf. Goldberg 1987,69. 
van gemeenschappelijke patronen die essentieel zijn voor het grootste aantal rechtssystemen ${ }^{631}$.

Met de ontwikkeling van modelclassificaties volgt de LCC de tendens om aan rechtssystemen gemeenschappelijke verschijnselen meer te benadrukken dan de verschillen ertussen ${ }^{632}$. Deze tendens werd al gemanifesteerd door het toepassingsgebied van de algemene K-klasse ${ }^{633}$ die in 1977 is geïntroduceerd binnen het geheel van het ordeningssysteem voor juridica. De K-klasse beoogt een compromis te zijn tussen de common law en de civil law ${ }^{634}$. Voor de algemene $\mathrm{K}-\mathrm{k}$ lasse resteren hoofdzakelijk die onderwerpsgebieden die van substantieel belang zijn voor vrijwel alle rechtsstelsels ${ }^{635}$. De algemene $\mathrm{K}$-klasse is van toepassing op de juridische documenten omtrent twee of meer landen, zoals Nederland en Suriname, die niet tot dezelfde geografische regio behoren ${ }^{636}$. Overigens wordt een rechtsstelsel ingedeeld bij de eigen regio, bijvoorbeeld Zuid-Amerika of Centraal-Europa ${ }^{637}$. De algemene K-klasse omvat een restcategorie en completeert het juridische ordeningssysteem van de LCC dat is gebaseerd op het rechtsstelsel en de regio als grondslagen. De eerste grondslag is de hoogste in rang en modelclassificaties komen op de tweede plats ${ }^{638}$. Het individualiserende vertrekpunt is niet volledig verlaten voor de juridische ordeningssystemen van de LCC.

\section{B. MODELCLASSIFICATIES}

Ter ontwikkeling van een modelclassificatie voor de civil law ${ }^{639}$ werd het Duitse recht gekozen omdat deze deelcollectie de grootste is binnen de Library of Congress ${ }^{640}$. De keuze voor de constructie van een modelclassificatie voor het Duitse recht is ingegeven door prioriteiten ${ }^{641}$ van de Library of Congress. Deze keuze is ook het resultaat van rechtsvergelijkend onderzoek. Van het Duitse recht werd aangenomen

631. Goldberg 1987; 69 . Een regio is niet uitsluitend geografisch bepald ondat rekening wordt gehouden mell de aanwezigheid van rechtsstelsels binnen een regio: of. Goldberg 1987, 68; cf. Goldberg 1994, 353.

632. Cf. Ellinger 1964, 364; cf. Moys 1968, 14.

633. Fischer 1977, in, $10,57$.

634. Goldberg 1977, 50.

635. Schon, 109; cf. Goldberg 1989, viii.

636. Goldberg 1989. xit.

637. Fischer 1977, iii.

638. Goldberg 1993, viii; cf. Goldberg 1994, 352 .

639. Cf. Goldberg 1987, 91 .

640. Ellinger 1956, 455; Ellinger 1968, 225 .

641. Goldberg 1986, 336 . 
dat het een belangrijke invloed heeft gehad op andere rechtsstelsels ${ }^{622}$. Rechtsvergelijkend onderzoek is voorts verticht voor de keuze van de classificatiebegrippen van de modelclassificatie voor Duits recht, de KK-klasse. Deze KK-klasse is een modelclassificatie die afwijkt van het individualiserende vertrekpunt van de LCC omdat de KK-klasse is ontworpen voor een groep rechtsstelsels die voldoet aan de definitie van een regio die in de vorige paragraaf $(\$ 5 . \mathrm{A})$ is weergegeven.

Goldberg heeft de KK-klasse ontwikkeld voor het recht van Duitsland en West-Duitsland; van de KK-klasse heeft zij de notaties van de KKA-klasse voor het toenmalige recht van de DDR afgeleid ${ }^{643}$. Het afleiden van notaties van de KK-klasse zou niet alleen voor het recht van de DDR mogelijk moeten zijn, maar ook voor alle civil law die is geordend volgens het Duitse rechtsstelsel ${ }^{644}$. Daartoe is de volgorde van het Duitse burgerlijk wetboek enigszins aangepast met het oog op de overige civil law die door het Duitse burgerlijke recht werd beïnvloed ${ }^{645}$. Goldberg heeft vergelijkenderwijs gezocht naar de gemeenschappelijke noemer die voor haar samenvalt met: de essentie van het dogma ${ }^{646}$. Voor het vaststellen van deze gemeenschappelijke noemer heeft Goldberg binnen het recht van de DDR een onderscheid moeten maken tussen beginselen van civil law en de socialistische doctrine ${ }^{647}$. Ondanks ideologische verschillen is het volgens Goldberg mogelijk rechtsbeginselen te vinden die van oorsprong Duits recht zijn ofschoon in het recht wan de DDR andere accenten zijn gelegd ${ }^{648}$.

Goldberg ${ }^{649}$ meent dat haar classificatiebegrippen voor de staatsorganen een goed voorbeeld leveren van wat zij noemt: 'classificatie door vergelijking' of een 'gesynchroniseerd ordeningssysteem'. Zij beweert dat de notaties van de KKA-klasse voor Oost-

642. Angetl, 356 .

643. Goldberg 1981a, 65 .

644. Golldberg 1981a, 60; Goldberg 1987, 91.

645. Golloberg 1981a, 72 noot 9, noent Japan, Griekenland, Pen en Brazilie. Cf. Goldberg 1981b, 150151 ; cf. Golliberg $1981 \mathrm{c}, 625$.

646. Goldberg 1981b, 152; cf. Goldberg 1981a, 67. De dogmatick spreekt over techtsnormen: cf. Gusy, 215.

647. Cf Goldberg 1982, ix. Volgens Goldberg 1986, 340, is het rechtssysteem van de woormalige DDR een gemengd rechtssysteem dat is stmengesteld uit elementen wan de civil law en de doctrine van de socialistische partij. De ontwikkelingen die nadien in Oost-Europa hebben plaatsgehad, maken de anpas van Goldberg niet minder interessant; ze tonen bovendien aan dat de indelingen wan rechtsstel. sels in hoge mate tijdgebonden zijn; cf. De Boer 1992, 44.

648. Cf. Goldberg 1981b, 155-156. Cf. Zweigert/Puttfarken 1978, 410 411: overeenkomstentussen socialistische en kapitalistische rechtsselsels zijn te verklaren met de gemeenschappelijke wóórsocialistische geschiedenis. Cf. David 1992, 231.

649. Goldberg 1981a, 68-69; Goldberg 1981b, 152-153; Goldberg 1981c, 629; Goldberg 1982, x. 
Duits recht afgeleid kunnen worden van die van de KK-klasse ofschoon er dogmatische verschillen zijn. Ondanks de wijziging van het oorspronkelijke rechtsbegrip onder invloed van de socialistische doctrine is er volgens Goldberg sprake van een socialistisch equivalent ${ }^{650}$. Goldberg veronderstelt dat er een gemeenschappelijke noemer aanwezig is omdat het rechtsbeginsel of de essentie van het dogma gemeenschappelijk is aan het toenmalige West-Duitse recht en het recht van de voormalige DDR. Het volgende voorbeeld illustreert de afleiding van KKA-notaties van een aantal KK-notaties:

KK 5049 GEWALTENTRENNUNG

KKA 5049 Zentralismus. GEWALtENVEREINIGUNG

KK 5318 BUNDESTAG

KKA 5318 VOLKSKAMMER

KK 5392 BUNDESPRÄSIDENT

KKA 5392 STAATSRAT. KOlLEKTIVES STAATSOBERHAUPT

KK 5418 BUNDESKANZLER UND KABINETT

KKA 5418 MINISTERRAT

KK 5440 BUNDESMINISTERIEN. OBERSTE BUNDESBEHÖRDEN KKA 5440 MINISTERIEN.

Omdat de linguïstische taal voor beide rechtsstelsels dezelfde is, blijkt de aanpassing van terminologie duidelijk uit dit voorbeeld. Het is echter de vraag of het staatsrechtelijke dogma in essentie identiek is voor genoemde organen terwijl de dogmatische verschillen te verwaarlozen zijn. Het is niet vanzelfsprekend dat 'Bundestag' een andere term is voor hetzelfde rechtsbegrip ${ }^{651}$ dat met "Volkskammer" wordt aangeduid in een ander rechtssysteem. Waar geen notatie wordt afgeleid van de KK-klasse, zoals bij KK'A 6631 voor 'Landwirtschaftliche Produktionsgenossenschaften', acht Goldberg ${ }^{652}$ de dogmatische verschillen blijkbaar doorslaggevend. Goldberg maakt onvoldoende duidelijk wanneer een gemeenschappelijk classificatiebegrip met een gemeenschappelijke notatie

650. Cf. Goldberg 1981c, 630 .

651. Cf. Zweigert/Puttarken 1978, 416, de socialistische staatsrechtelijke organesu wijken fundamenteel af wan die van de niet-socialistische landen.

652. Cf. Goldberg 1981b, 160; cf. Goldberg 1986, 343. 
is toegestaan en wanneer niet. De modelclassificatie van Goldberg berust op vereenvoudigende veronderstellingen ${ }^{653}$.

\section{HIËrRARCHISCHE RELATIES}

De keuze van indelingskarakteristieken voor een rechtsvergelijkend ordeningssysteem moet ertoe leiden dat de hiërarchische relaties van de rechtsvergelijkende classificatiebegrippen aansluiten bij de hiërarchische relaties van de nationale rechtsbegrippen. Het is echter de vraag of een rechtsvergelijkend ordeningssysteem volledig in de pas kan lopen met de hiërarchische relaties binnen de rechtsstelsels waarop dat ordeningssysteem betrekking heeft. Dat blijkt uit de hiërarchische relaties van de algemene $\mathrm{K}$-klasse, een compromis tussen de common law en de civil law ${ }^{654}$. Deze K-klasse bevat uitsluitend rechtsvergelijkende classificatiebegrippen omdat hetzelfde classificatiebegrip verwijst naar documenten met betrekking tot meer dan één rechtsstelsel ${ }^{655}$. Dat is niet het geval voor modelclassificaties omdat daarin uitzonderingen voorkomen als een gemeenschappelijke noemer ontbreekt ${ }^{656}$. Daarom wordt hier een voorbeeld genomen uit de algemene K-klasse en niet uit een modelclassificatie van de LCC. Dit voorbeeld is de Engelse 'real mortgage' en 'chattel mortgage' en de Franse 'hypothèque' en 'hypothèque mobilière' ${ }^{657}$; deze rechtsbegrippen behoren tot de common law respectievelijk de civil law.

De hiërarchische relaties van de Engelse en de Franse 'hypotheek' vallen niet samen. Dat is onderkend in de classificatiebegrippen van de LCC voor het Engelse en Franse rechtsstelsel. De LCC bevat de KD-klasse voor het Engelse recht en de KJV-klasse voor het Franse recht ${ }^{658}$. Voor beide klassen geldt het individuele rechtsstelsel als grondslag. De volgende vergelijking van de hiërarchische relaties van de classificatiebegrippen laat zien dat rekening is gehouden met uiteenlopende hiërarchische relaties van de rechtsbegrippen. In đe KD-klasse is de 'hypotheek' ${ }^{359}$ in twee hiêrarchieën ingedeeld:

653. Cf. Svenonius 1979, 209 .

654. Zie IV.\$ 5.A.

65. Zie IV.\$3.A.

656. Zie IV.\$5.B.

657. Zie III. \$ 3.B.

658. Fischer 1973; respectievelijk Goldberg 1985. De LCC bevat malast de regionale ordeningssystemen volledig ontwikkelde, individuele ordeningssystemen voor onder meer Frankrijk en Groct-Brittamnie: Goldberg 1987, 67,69.

659. Strikt genomen is 'mortgage' onvertaalbaar; een alternatieve vertaalsuggestie is 'grondpandrecht': ef. Stöcker, 202. 
PROPERTY

REAL PROPERTY

MORTGAGES (=KD 1013)

CONTRACTS

PARTICULAR CONTRACTS

SECURED TRANSACTIONS

PARTICULAR TRANSACTIONS

ChATTEL MORTGAGES ( $=$ KD 1757)

In de KJV-klasse, die naast de Engelse vertaling de Franse termen bevat, zijn de hiërarchische relaties als volgt:

SECURITY/SÛRETÉS

RIGHTS IN REM UPON DEBTOR'S PROPERTY/SÛ̉RETÉS RÉELLES

PRIVILEGES AND MORTGAGES/ PRIVILËGES ET HYPOTHEQQUES

MORTGAGES/ HYPOTHEQUES (=KJV 2166)

CHATtEL MORTGAGES/ HYPOTHĖQues MOBILIÈRES (=KJV 2167)

In de K-klasse tenslotte zijn de volgende hiërarchische relaties opgenomen:

\section{PROPERTY}

REAL PROPERTY

REAL RIGHTS OF GUARANTY ON REAL PROPERTY

MORTGAGES $(=\mathrm{K} 778)$

COMMERCIAL CONTRACTS

SECURED TRANSACTIONS

CHATTEL MORTGAGES (=K 1102)

Opvallend aan bovenstaande voorbeelden is dat de hiërarchische relaties in de K-klasse grotendeels overeenkomen met die in de KD-klasse en niet met die in de KJV-klasse. De K-klasse is hier gebaseerd op de common law en niet op de civil law. Verder blijkt dat de KJV-klasse "biens immeubles" niet opneemt als hoger classificatiebegrip voor 'hypothèque' terwijl de K-klasse en de KD-klasse 'mortgage' ondergeschikt maken aan 'real property'. Daardoor wijkt de KJV-klasse in dit voorbeeld meer af van de hiërarchische relaties van de nationale rechtsbegrippen ${ }^{660}$. Voor het gemak van de gebrui-

660. Zie III. \$ 3.B. 
ker is de 'chattel mortgage" in alle drie de klassen bij 'security' ingedeeld, het thema van de relevante literatuur ${ }^{66 !}$.

In het volgende hoofdstuk komen de rechtsvergelijkende thesauri aan de orde, een ander toepassingsgebied waarvoor comparatieve begrippen bruikbaar kunnen zijn.

661. Cf. Ellinger 1964, 363; cf. Mills, $21,26$. 


\section{Rechtsvergelijkende thesauri}

\section{$\S 1$. Begripsrepresentatie met een thesaurus}

\section{A. RELATIES TUSSEN DESCRIPTOREN}

Een thesaurus is een verzameling woorden die zijn geselecteerd en gerelateerd op een zodanige wijze dat begrippen worden ingedeeld en weergegeven ${ }^{662}$. De thesaurus verdient bespreking in een afzonderlijk hoofdstuk, omdat de thesaurus wordt gekenmerkt door een grotere nadruk op begripsrepresentatie dan het geval is voor het ordeningssysteem dat in het vorige hoofdstuk is behandeld. Bij thesauri ligt er veelal een grotere nadruk op de selectie en de relaties van woorden uit de natuurlijke taal ${ }^{663}$. Daarom begint dit hoofdstuk met een bespreking van de begripsrepresentatie die met een thesaurus wordt beoogd. Onderdeel V. $\$ 1 . B$ behandelt de hiërarchische relaties tussen de woorden die zijn geselecteerd voor een thesaurus. Omdat bij de constructie van een thesaurus meer rekening wordt gehouden met automatiseringsmogelijkheden dan in het geval van ordeningssystemen, wordf V. $\$ 2$ gewijd aan de geautomatiseerde thesaurus. Daarna volgt de toepassing van een thesaurus op juridische documenten; de bijzondere problemen die daarmee gepaard gaan, worden in V. $\$ 3$ besproken. Tenslotte worden rechtsvergelijkende thesauri aan de orde gesteld: thesauri waarmee documenten omtrent verschillende rechtsstelsels teruggevonden kunnen worden. Daartoe moeten de woorden van een rechtsvergelijkende thesaurus de rechtstermen van verschillende rechtsstelsels zo goed mogelijk dekken. Rechtsvergelijkende thesauri vormen het toepassingsgebied

662. Er bestaat allerminst eenstemmigheid omtrent de definitie van een thesaurus zoals blijkt vit het, overzicht van Wersig, 25-28. Cf. Riesthuis/Wijands, 21 ; cf. Voorbij, 198.

663. Cf. Aitchison/Gilchrist, 122-123. 
waarwoor comparatieve begrippen indirect nut kunnen hebben ${ }^{664}$ zodat een uitvoerige bespreking gerechtvaardigd is.

Er zijn voor de constructie van een thesaurus aanbevelingen of richtlijnen opgesteld die bij het selecteren en relateren van descriptoren in acht genomen moeten worden. Deze richtlijnen zijn geen dwingende voorschriften en bieden veelal geen definitieve oplossingen voor el.k probleem ${ }^{605}$. Het doel ervan is de toekenning van zodanige descriptoren aan documenten dat deze documenten onder het gerepresenteerde begrip teruggevonden kunnen worden door de gebruiker van de thesaurus. De begripsrepresentatie die met een thesaurus wordt beoogd, maakt selectief gebruik van natuurlijke taal. Een thesaurus onderwerpt woorden uit de natuurlijke taal an beperkingen alvorens die woorden op te nemen in permanente relaties ${ }^{666}$ voor de begripsrepresentatie. Er worden woorden wit de naturlijke taal geselecteerd omdat toevallige formuleringen in het document of de vraagstelling geëlimineerd moet worden en herleid moeten worden tot begrippen ${ }^{667}$. Daartoe worden courante en eenduidige woorden geselecteerd ${ }^{668}$. De geselecteerde woorden of woordgroepen ${ }^{669}$ worden 'descriptoren' 670 genoemd. Elke descriptor representeert één begrip ${ }^{671}$. Om de begripsrepresentatie onafhankelijk van toevallige formuleringen te doen zijn, beperkt een thesaurus de varianten eigen aan de natuurlijke taal. Zo zal een thesaurus een aantal spellingsvarianten buiten gebruik laten. Voor Nederlandse thesauri is het meervoud meestal uitgangspunt voor de redactie van descriptoren ${ }^{67}$. Bovendien mogen woordvormen zoals "wettig', "wettige', 'wettigen', 'gewettigd", 'gewettigde', 'wettiging' niet allemaal verschillende descriptoren opleveren. Dergelijke varianten worden genormaliseerd ${ }^{673}$ om tot een selectie te komen die voor opname in een thesaurus geschikt wordt geacht ${ }^{674}$. De toegelaten varianten zijn descriptoren.

664. Zit III. 85.6 .

665. Cf. Austin, 351; cf. Riesthuis/Wijnands, 37, 122, 126 ; cf. Sieverts/Groeneveld/Hofstede 95.

666. Riesthis/Wijnands, 45 .

667. Javsen. 13.

668. Schwck, 459.

669. Riesthuls/Wijnands, 21.

670. Daarmee wordt aangedtuid dat het on elementaire ternen gaat: Voorbij, 200.

671. ISO, 3; Aitchison/Gilchrist, 12; cf. Aitchison/Gilchrist, 108. Cf. Voskamp, 319: in een thesaurus staan de begrippen centraal.

672. Riesthuis/Wijnands $s_{4} 54$

673. Doch niet gestandaardiseerd: Anders, 55-56.

674. Cf. Palstra 1969b, 462, 464. 
Eenduidige begripsrepresentatie wordt nagestreefd met de normalisatie van mogelijke relaties tussen de descriptoren van een thesaurus ${ }^{675}$. De descriptoren van een thesaurus worden met genormaliseerde relaties vastgelegd zodat een begrip eenduidig wordt gerepresenteerd door een descriptor. Binnen een thesaurus bestaat een wederzijdse afharkelijkheid van de descriptoren ${ }^{676}$ " De thesaurus bevat een relatiepatroon ${ }^{677}$ : elke descriptor is met één of meer andere descriptoren verbonden. Tot de genormaliseerde relaties van een thesaurus behoren hiërarchische relaties enerzijds en nevenschikkende relaties anderzijds. Een hiërarchische relatie tussen descriptoren sluit een nevenschikkende relatie tussen diezelfde descriptoren uit ${ }^{678}$. Op de hiërarchische relaties wordt in V.\& 1.B ingegaan. De nevenschikkende relaties komen hier aan de orde. Beide soorten relaties fixeren de betekenis van de descriptoren van een thesaurus; deze relaties kunnen worden gebruikt bij de keuze van descriptoren om documenten terug te winden.

Van belang zijn de volgendle nevenschikkende relaties:

$\mathrm{USE}^{679}$ voor de verbinding van een non-descriptor ${ }^{680}$ met een descriptor ${ }^{681}$;

UF ('use for' ${ }^{682}$ ) voor de verbinding van een descriptor met een non-descriptor.

Deze relaties worden toegekend in het geval van synoniemen: woorden die hetzelfde begrip aanduiden zoals 'auto' en 'motorvoertuig' ${ }^{683}$. Zo kan in een thesaurus voor 'assurantie' consequent 'verzekering' als descriptor worden gebruikt, terwijl de ingang "assurantie" dankzij USE verbonden is met het synoniem 'verzekering' ${ }^{684}$. Hier is vereist dat descriptor en varianten hetzelfde begrip weergeven ${ }^{685}$. In het geval van nevenschikkende relaties tussen synoniemen wordt éên synoniem als descriptor gekozen, terwijl de varianten uit de natuurlijke taal verbonden zijn met die descriptor. Deze varianten uit de natuurlijke taal worden uitgesloten als descriptor en worden 'non-de-

675. Genomaliseerde relaties tussen de descriptoren kunnen tot de eigenschappen van een thesaurus worden gerekend: cf. Voorbij, 201.

676. Cf. Knapp, 269.

677. Cf. Knapp, 283: een thesaunus is een gecompliceerd netwerk van "knopen" (descriptoren) die wederzijds verbonden zijn.

678. Sieverts/Groeneweld/Hofstede, 94.

679. De afkortingen woor de verschillende relaties tussen descriptoren zijn volgens internationall antalard gebruilk in het Engels.

680. De non-descriptor kan ook werwijsterm of ingangsterm worden genoend: cf. Aitchison/Gilchrist, 12.

681. Riesthuis/Wijnands, 40: een 'descriptor' wordt ook 'woorketristerm' genoemd.

682. 'Use for' gaat wit van de gebruiker van de thesauris die documenten zoeki; "used for" is gericht tot degene die documenten klasseert: cf. Riesthuis/Wijnands, 22, 45.

683. Cf. Herberger/Simon, 258.

684. Cf. Palstra 1969b, 462. In geautomatiseerde bestanden wordt de goede zoekterm gezocht bij het door de eindgebruiker opgegeven synoniem: Van de Walle, 50.

685. Wersig, 52 . 
scriptoren' genoemd. Deze non-descriptoren behoren tot de thesaurus maar worden niet gebruikt woor documenten of zoekacties ${ }^{636}$. De descriptoren worden toegekend aan de documenten ${ }^{687}$ die met de thesaurus in kwestie teruggevonden moeten kunnen worden. Om die descriptoren te kunnen hanteren wordt de gebruiker van een thesaurus vanuit de natuurlijke taal geleid naar de juiste descriptor. De varianten uit de natuurlijke talal vormen de ingang tot de descriptoren. In het belang van de gebruikers van de thesaurus moet ernaar worden gestreefd om daarin zoveel mogelijk non-descriptoren als zoekleiding op te nemen ${ }^{688}$.

Eventueel kan hetzelfde begrip aanwezig worden geacht als onderscheidingen voor het doel van een thesaurus overbodig zijn. Gelet op het doel van een thesaurus kan de equivalentie van deze zogeheten "quasi-synoniemen" worden geponeerd ${ }^{6.9}$. Zo kunnen de varianten 'Roß', 'Gaul', 'Mähre', 'Klepper' synoniem worden verklaard met de descriptor 'Pferd' ${ }^{690}$. Dit laat onverlet de verschillende betekenissen van 'Roß', 'Gaul', 'Mähre" en 'Klepper' buiten de thesaurus in kwestie ${ }^{691}$. Binnen de thesaurus wordt de extensie ${ }^{692}$ van het begrip weergegeven met de descriptor 'Pferd' vergroot door de relatie met de quasi-synoniemen die als non-descriptoren worden opgenomen.

Zowel synoniemen als quasi-synoniemen vormen equivalentierelaties ${ }^{693}$. Equivalentierelaties zijn nevenschikkende relaties. Andere nevenschikkende relaties zijn associatieve relaties of verwantschapsrelaties. Associatieve relaties bieden een zoekleiding die wordt afgekort met: RT ('related term'). Omdat het criterium voor associatieve relaties afhankelijk is van hetgeen als ingang nodig wordt geacht voor de gebruikers van een thesaurus, is dit criterium tamelijk arbitrair ${ }^{694}$. Om dit met een voorbeeld te illustreren: als 'related term' bij de descriptor 'Meerssen' zou in een thesaurus 'Nederlandse kampioenschappen wielrennen op de weg' opgenomen kunnen worden omdat met deze toevoeging een associatie met de gemeente Meerssen opgeroepen wordt, althans bij een beperkte gebruikersgroep. Andere gebruikersgroepen kunnen met andere associaties als zoekleiding gediend zijn. Het is onduidelijk waar de grens ligt. Hier volstaat dan ook de con-

686. Liloyd, 21 .

687. Riesthuis/Wijnands, 40 ,

688. Aitohison/Gilchrist, 37 ; cf. Riesthuis/Wijnands, 65 .

689. Cf. Aitchison/Gilclurist, 37; cf. Schuck, 452. Cf. Knapp, 279: kunstmatige synoniemen gaan woorbij aan thet eventueel onibreken van synoniemen in de nanuurlijke taal.

690. Wersig, 52-53.

691. Cf. Austin, 348.

692. Zie II.S1.

693. Aitchison/Gilchrist, 35 .

694. Gödert, 158 . 
statering dat het bij associatieve relaties tussen termen gaat om verwantschapsrelaties die geen synoniemen of hiërarchische relaties opleveren ${ }^{695}$. Associatieve relaties vormen een restcategorie ${ }^{696}$ die verder buiten beschouwing zal bijiven.

\section{B. Hiërarchische relaties}

Behalve nevenschikkende relaties kan een thesaurus hiêrarchische relaties bevatten. Het is echter niet noodzakelijk dat een thesaurus hiërarchische relaties bevat. Hiêrarchische relaties tonen niveaus van bovenschikking en onderschikking ${ }^{697}$. Deze hiërarchische relaties verbinden descriptoren voor soortbegrippen en die voor meer specifieke begrippen. Daartoe is vereist dat de meer specifieke begrippen ondergeschikt zijn aan het soortbegrip ${ }^{698}$. De deel-geheel-relatie tussen objecten behoort niet tot de hiërarchische relatie tussen intensies van begrippen ${ }^{69}$. De deel-geheel-relatie tussen bijwoorbeeld 'fietsbel' en 'fiets' moet niet worden verward met de hiërarehische relatie tussen 'kinderfiets' en 'fiets'. Dit verschil kan als volgt worden toegelicht. elke kinderfiets is tevens een fiets. Het soortbegrip 'fiets' kan roegepast worden op het object 'kinderfiets' . Dit geldt echter niet voor de deel-geheel-relatie: een fietsbel is nier tevens een fiets, maar een onderdeel van een fiets. Het hogere soortbegrip is hier "bel". Het soortbegrip 'fiets' kan niet worden toegepast op het object 'fietsbel". Hiërarchische relaties die deelgeheel-relaties omvatten, zijn misleidlend. De relatie tussen Londen en Engeland is niet de relatie tussen een specifiek begrip en een soortbegrip want van Londen kan niet worden gezegd dat het een soort Engeland is ${ }^{700}$. Het verdient de voorkeur de deelgeheel-relatie, bijvoorbeeld tussen landen en hun continent, als een associatieve relatie te beschouwen ${ }^{701}$.

695. Riesthuis/Wijnands, 71.

696. 'Tot de associatieve relaties in een juridische thesaurus behoren relaties als 'is een gevolg van' of 'ligt ten grondslag aan": Raming, 10 ; of. Riesthuis/Wijnands, 86.

697. Riesthuis/Wijnands, 21.

698. Zie IV.\& 1.A.

699. Cf. Bellertwojtasiewicz, 157

700. Mills, 26.

701. Cf. Aitchison/Gilchrist, 42; cf. Riesthuis/Wijnands, 69. Volgens Aitchison/Gilchrist, 39, kan de hiërarchische relatie van een thesauns behalve voor een generieke relatie ook staan voor een deelgeheel-relatie. 
Als een thesaurus hiërarchische relaties bevat, nemen zij een minder prominente plaats in dan bij ordeningssystemen ${ }^{202}$. Er is geen tegenstelling tussen thesauri en ordeningssystemen in die zin dat een ordeningssysteem $a$ priori is vastgelegd en een thesaurus niet ${ }^{703}$. Een $a$ priori thesaurus waarin eenmalig alle begrippen worden vastgelegd en geen wijzigingen of toevoegingen meer mogelijk zijn, is denkbaar ${ }^{704}$. Bovendien kan een ordeningssysteem ten grondslag liggen aan de indeling van een thesaurus ${ }^{705}$. Er is veeleer sprake van een gradueel verschil tussen ordeningssystemen en thesauri. Thesauri bieden in het algemeen meer mogelijkheden voor expansie omdat descriptoren niet per se in hiërarchische relaties ondergebracht behoeven te worden. Er is echter geen sprake van een absolute tegenstelling zodat de thesaurus een open karakter zou bezitten en het ordeningssysteem een gesloten karakter.

Een thesaurus toont hiërarchische begripsrelaties in het alfabetische register op de thesaurus. Ook de nevenschikkende relaties worden gepresenteerd in het alfabetische register op de thesaurus. Dit register bevat de alfabetische rangschikking van de descriptoren $^{706}$ en is veelal het meest uitgebreide deel van een thesaurus ${ }^{707}$. In het alfabetische register van een thesaurus worden de hiërarchische relaties tussen de descriptoren als volgt afgekort:

BT ('broader term') = hogere, ruimere descriptor;

NT ("narrower term") = lagere, meer specifieke descriptor.

Het volgende voorbeeld ${ }^{708}$ van een fragment van een alfabetisch register op een thesaurus kan illustreren hoe meer hogere en lagere hiërarchische niveaus weergegeven kunnen worden:

\section{DEPRIVED FAMILIES}

UF UNDERPRIVILEGED FAMILIES

BT1 FAMILIES

BT2 SOCIAL INSTITUTIONS

702. Cf. Crunwald, 26: een ruime opvatting omtrent het begrip "classiticatie' leidt ertoe dat een thesaunss als zodanig een ordeningssystem is, ook al bevat een thesantrus andere dan strikt hierrarchische relaties. Een ondeningssysteem bevat echter hierarchische relaties tussen classificatiebegrippen, niet oussen deseriptoren.

703. Deze veronderstelling is te vinden bij Voorbij, 202-203.

704. Cf. Vaskamp, 320.

705. Cf. Aitchison/Gilchrist, 129.

706. Cf, Voorbij, 201: een thesaurus is een (...) verzameling van descriptoren in alfabetische volgorde, watrbij hiërarclische relaties tussen de descriptoren aangegeven kunnen zijn.

707. Riesthuis/Wijnands, 109.

708. Aitchison/Gillchrist, 72. 


\section{NT1 HOMELESS FAMMLIES \\ NT1 ONE-PARENT FAMILIES \\ NT2 FATHERLESS FAMLLIES \\ RT DEPRIVATION.}

Een presentatie van hiërarchische relaties in het alfabetisch register is onvolledig indien daarin niet alle hiërarchische niveaus tussen de descriptoren zichtbaar worden gemaakt. Een systematisch register kan het alfabetisch register van een thesaurus ondersteunen ${ }^{709}$ met een volledige weergave van de hiërarchische niveaus tussen de descriptoren. In het systematische register zijn de descriptoren geordend volgens de hiërarchie van de begrippen die met de descriptoren worden weergegeven. Alle trappen van de hiërarchie, alle hogere en lagere descriptoren zijn in het systematische register te vinden. Het volgende voorbeeld dat is ontleend aan de 'Index Medicus', een thesaurus gekoppeld aan een ordeningssysteem ${ }^{710}$, kan dat illustreren:

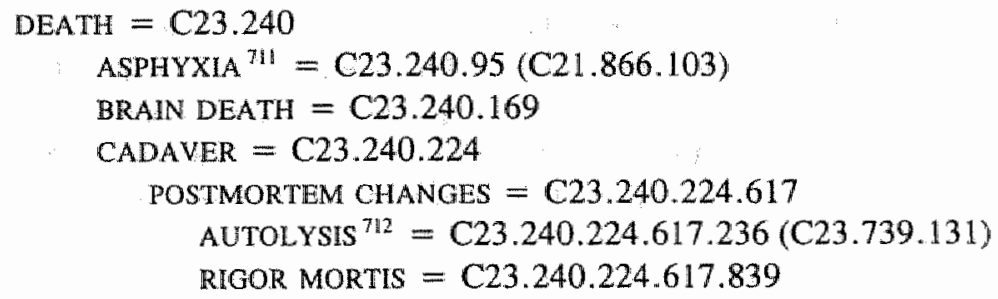

Aan het inspringen en aan de notatie ${ }^{713}$ is te zien dat ASPHYXIA, BRAIN DEATH en CADAVER zich op dezelfde trap van de hiërarchie bevinden. Uit de notaties tussen haakjes blijkt bovendien dat er sprake is van een polyhiërarchie voor de descriptoren ASPHYXIA en AUTOLYSIS: deze descriptoren blijken meer dan éen "broader term" te hebben ${ }^{714}$. Voor deze descriptoren is het voorbeeld onvolledig: de presentatie van de begripshiërarchie zou pas volledig zijn als de gehele begrippenpiramide met alle niveaus zichtbalar zou worden gemaakt. Dat zou vereisen dat niet alleen de rubriek C23.240 maar ook de rubrieken C21.866 en C23.739 integraal gepresenteerd zouden worden. Niettemin blijkt

709. Aitchison/Gilchrist, 70 .

710. Cf. Weinberg, 30.

711. Zonder polsslag.

712. Destructie yan lichaamscellen.

713. De notaties werwijzen maar het alfabetische register: Aitchison/Gilchrist, 79.

714. Cf. Aitchison/Gillchrist, 43; cf. Riesthuis/Wijnands, 70; cf. Wheinberg. 35 . 
wit het voorbeeld dat het systematische register kan tonen dat voor dezelfde descriptor meer dan ến hiêrarchie aanwezig is.

\section{§2. De geautomatiseerde thesaurus}

\section{A. GEAUTOMATISEERD ZOEKEN}

Een computer ${ }^{715}$ maakt het mogelijk een thesaurus op geautomatiseerde wijze te raadplegen. Dit vergemakkelijkt het gebruik van de thesaurus, ofschoon de automatisering van het zoekproces geen remedie is tegen een verkeerde inhoudsanalyse en het daardoor onjuist toekennen van descriptoren. Met een computer kan efficiënter en sneller worden gezocht dan mogelijk zou zijn met het handmatig raadplegen van de papieren editie van een thesaurus. De computer biedt extra faciliteiten om bij de gezochte descriptoren te komen en om gevonden descriptoren te combineren. Geautomatiseerd zoeken is voor een thesaurus van groter belang dan voor een ordeningssysteem, omdat de constructie van een thesaurus is gebaseerd op de mogelijkheid om descriptoren tijdens de zoekfase te combineren zodat de gebruiker niet is gebonden aan vaste combinaties van woorden in een voorgeschreven volgorde ${ }^{716}$. Logische operatoren om met meer descriptoren tegelijkertijd te kunnen zoeken, zijn vrijwel onontbeerlijk voor een thesaurus ${ }^{717}$. Dat geldt in mindere mate voor truncatie ${ }^{718}$, een faciliteit wan geautomatiseerd zoeken die eerst besproken zal worden.

Truncatie is een faciliteit die bij handmatig zoeken ontbreekt. Met behulp van truncatie kunnen descriptoren worden gevonden. Met truncatie wordt geautomatiseerd gezocht naar alle descriptoren in een thesaurus die beginnen met dezelfde letters. Truncatie is het zoeken naar woordfragmenten ${ }^{719}$. Truncatie vindt plaats door het gebruik van een teken, bijvoorbeeld \#, dat staat voor alle eventueel aanwezige letters die genegeerd

715. Veelal gat het daarbij on een thesaurus die met teksten of bibliografische gegevens elektronisch toegankelijk is. De descriptoren zijn opgeslagen op een CD-ROM-schijf, of in een extern computergelyeugendat op afstand ('online) kan worden geraadpleegd. Bibliografische gegevens zijn geen teksten, matr yerwijzen naar documenten.

716. Riesthuis/Wijnands, 34, 59. Een thesaurus pretendeert niet gebruikersvragen te kumen woorspellen door slechts bepaalde combinaties van zoektermen tevoren vast te leggen; cf. Van Laer $1987 \mathrm{~b}, 141$.

717. Riesthuis/Winands, 19 .

718. Truncatie kan niet alleen op descriptoren, maar ook op expressieve notaties (zie IV.\$2.A) van ordeningssystemen worden toegepast. Notaties kunnen eweneens worden gecombineerd met logische operatoren. Deze faciliteiten van geautomatiseerd zoeken worden hier besproken omdat ze van groter belang zijn voor thesauri.

719. Aitchison/Gillchrist, 64. 
moeten worden ${ }^{720}$. Zoeken op BIBLIOT\# levert dan bij een rechtszijdige ${ }^{721}$ truncatiefaciliteit:

BIBLIOTHECARISSEN

BIBLIOTHEEKAUTOMATISERING

BIBLTOTHEEKBOUW

BIBLIOTHEEKCATALOGI

BIBLIOTHEEKCOLLECTIES

BIBLIOTHEEKINTERIEUR

BIBLIOTHEEKWETENSCHAPPEN

BIBLIOTHEKEN

BIBLIOTHERAPIE

Uit dit voorbeeld blijkt dat men met truncatie een descriptor op het spoor kan komen die men niet op voorhand in de thesaurus vermoed had. Met truncatie kan bovendien het gebruik van ontbrekende spellingsvarianten vermeden worden: de descriptor BIBLIOTHEEKKOLLEKTIES komt in het bovenstaande voorbeeld niet voor. Degene die naar dit onderwerp zoekt, kan dankzi truncatie met de in de thesaurus gehanteerde spelling rekening houden en voorkomen dat hij geen enkel document vindt.

Terwijl truncatie vooral een rol speelt bij het oriënterend zoeken, worden logische operatoren veeleer toegepast bij het gericht zoeken. Logische operatoren bieden de mogelijkheid om een combinatie van descriptoren in de zoekactie te betrekken ${ }^{722}$. De volgende logische operatoren zijn van belang: met ' $\mathrm{EN}$ ' wordt gevraagd naar de doorsnede van twee of meer deelverzamelingen; en met 'OF' wordt gezocht naar cle vereniging van twee of meer deelverzamelingen. Met 'EN' kan worden gezocht naar die documenten waaraan zowel de descriptor "universiteiten" als de descriptor "Maastricht' zijn toegekend. De logische operator 'EN' werkt als een trechter' of fuik. De operator 'OF' verbreedt de zoekactie juist; bijwoorbeeld in: 'universiteiten OF Maastricht'. In het tweede voorbeeld levert de zoekactie, behalve de in het eerste voorbeeld gevonden documenten, nog documenten uitsluitend over "universiteiten" of uitsluitend over "Maastricht', aangenomen dat die aanwezig zijn in de collectie die met deze thesaurus wordt ontsloten.

720. Cf. Riesthuis/Wijnands, 18.

721. De linkszijdige truncatie en andere varianten bljwen hier buiten beschouwing. $C f$. Riesthuis/Wijnands, 19: veelal is slechts rechtstruncatie mogelijk.

722. Cf. Aitchison/Gilchrist, 63, met de waarschuwing om de "NOT"-operator terughoudend te hanteren. 
Truncatie en logische operatoren zijn minimale hulpmiddelen om geautomatiseerd te zoeken in een thesaurus. Voor het zoeken in een thesaurus kunnen nog meer computerfaciliteiten worden ontwikkeld ${ }^{723}$. Twee aanbevelingen ${ }^{724}$ zijn daarvoor opgesteld: het beeldscherm moet niet alleen kunnen tonen wat het zoekresultaat is, maar ook langs welke wegen dat resultaat is bereikt. Bovendien werdient het aanbeveling dat de gebruiker het eerst wordt geconfronteerd met die descriptoren die zich in de thesaurus op het hoogste hiërarchische niveau bevinden ${ }^{725}$. Desgewenst moet hij de meer specifieke descriptoren op het eerstwolgende $\|$ agere niveau te zien kunnen krijgen ${ }^{726}$. Daarna moet de gebruiker kunnen overstappen naar een ander hiërarchisch niveau, naar alternatieve hiërarchieën, of naar anderszins gerelateerde descriptoren. Nadat de descriptoren definitief zijn geselecteerd, kunnen er logische operatoren toegepast worden: Aan deze aanbevelingen kan het desideratum worden toegevoegd dat de computer voor elke fase van de zoekactie vermeldt hoeveel documenten er gevonden zijn. In het algemeen zijn de beschikbare beeldschermpresentaties onvoldoende afgestemd op de behoeften van degene die zoekt ${ }^{727}$.

De constructie van een thesaurus is gebaseerd op de mogelijkheid om descriptoren tijdens de zoekfase te combineren met logische operatoren. Het zoeken met logische operatoren heeft grote invloed op 'opbrengst' en 'precisie' van het resultaat van een zoekactie ${ }^{728}$. De toelichting op deze criteria in V. $\S 2 . B$ kan de constructie van de thesaurus ${ }^{729}$ verduidelijken.

\section{B. OPBRENGST EN PRECISIE}

Een zoekactie die met behulp van een thesaurus wordt uitgevoerd, resulteert in een 'vangst' ${ }^{730}$. Deze vangst kan bestaan uit: geen enkel document, één document of meer documenten. De vangst is het aantal feitelijk gevonden documenten en wordt

723. Riesilhuis/Wijmands; 114 .

724. McLelland, 203, 204.

725. Deze anubeveling gat verder dan de wens dat de sottware het systematisch register zichtbaar moet kunnen maken: of. Aitchison/Gilchrist, 148. Overigens moet de gebruiker de mogelijkheid worden geboden van een standardinstelling af te wijken.

726. Cf. Weinberg, 39.

727. Riesthuis/Wijnands, 107.

728. Riesthuis/Wijnands, 19 ,

729. Het resultat van een zoekactie met een ordeningssysteem heeft eveneens een opbrengsten een precisie, mat ondat een ordeningssysteem minder dan een thesaurus is gebaseerd op de mogelijkheid van geautomatiseerd zoeken met logisclye operatoren, worden genoemde criteria hier behandeld.

730. Ook "(bruto)opbrengst" genoemd: Riesthuis/Wijnands, 16. 
uitgedrukt in absolute getallen. Hiervan te onderscheiden zijn de "opbrengst" en de 'precisie': opbrengst en precisie zijn verhoudingsgetallen om het resultaat van een zoekactie aan te geven. Opbrengst en precisie zijn aspecten van de vangst ${ }^{73 !}$. Zowell opbrengst als precisie zijn verhoudingsgetallen die het prestatievermogen van een thesaurus aanduiden. Alleen een perfect samengestelde thesaurus die volmaakt is gehanteerd, levert een precisie van $100 \%$ en een opbrengst van $100 \%$. Dit komt in de praktijk niet voor.

Als de vangst documenten bevat, kan deze vangst worden gesplitst in documenten die handelen over het gezochte onderwerp en in documenten die niet daarover gaan. De eerste categorie is per definitie relevant ${ }^{732}$, de tweede categorie is dat niet. Daarbij dient te worden bedacht dat relevantie van documenten mede wordt bepaald door de thesaurusgebruiker die naar documenten over een of ander onderwerp zoekt ${ }^{733}$. De verhouding tussen de relevante deelverzameling van de vangst en de ten onrechte gevonden irrelevante deelverzameling van diezelfde vangst, wordt 'precisie" genoemd ${ }^{734}$. Dit verhoudingsgetal is te onderscheiden van de 'opbrengst'. Als de vangst niet alle in de collectie aanwezige documenten over het gezochte onderwerp bevat, is de opbrengst niet $100 \%$. In dat geval bevat de collectie die met een thesaurus wordt ontsloten, relevante documenten die ten onrechte buiten de gevonden verzameling vallen. Dit aspect van de vangst wordt aangegeven met de opbrengst: de verhouding tussen het aantal feitelijk gevonden documenten over het gezochte onderwerp en alle relevante documenten in de collectie ${ }^{735}$. Bij een hogere opbrengst worden meer relevante documenten gevonden, een hogere precisie leidt tot een sterkere reductie van het aantal irrelevante documenten in de vangst ${ }^{736}$. De opbrengst is echter moeilijk te meten omdat het aantal relevante documenten dat niet is gevonden, zelden bekend is; daarentegen is de precisie tamelijk gemakkelijk te berekenen omdat daarvoor niet bekend behoeft te zijn welk deel van een collectie niet is gevonden met een zoekactie ${ }^{737}$.

De opbrengst en de precisie dlie met een thesaurus worden bereikt, zijn geen absolute gegevens, maar gerelateerd aan de opbrengst en de precisie van het zoekresultaat waar-

731. Deze teminologie is overigens niet vast.

732. Riesthuis/Wijnands 10,16 . Overigens kan de frequentie van een of ander woord bepalend zijn voor de relevantie van een document ten opzichte van andere documenten waarin het gezoclate woord minder vaak voorkomt. In dat geval doen zich graduele verschillen in relevantie voor.

733. Dabney. 15; cf. Riesthuis/Wijnands, 16.

734. Riesthuis/Wijnands, 16.

735. Ook 'vangst(verhouding)' genoemd: Riesthuis/Wijnands, 16 en noot 4.

736. Aitchison/Gillchrist, 8.

737. Dabney, 16. 
voor geen gebruik is gemaakt van een thesaurus, bijwoorbeeld omdat uitsluitend in ongecontroleerde woorden van documenten is gezocht. Zoekacties in teksten waaraan geen descriptoren zijn toegewoegd, leiden veelal tot een minder precies resultaat. De woorden in de titels van juridische tijdschriftartikelen zijn niet altijd voldoende precies ${ }^{738}$. Dit geldt bijvoorbeeld ook voor de titels van 'statutes' in het Verenigd Koninkrijk deze titels geven geen uitsluitsel over de inhoud wan de 'statutes' en kunnen zelfs misleidend zijn ${ }^{739}$. Overigens kan het toekennen van descriptoren de opbrengst van de vangst verhogen, bijwoorbeeld wanneer het begrip 'goodwill' niet consequent wordt gebruikt in de uitspraken die daarover gaan ${ }^{740}$.

Het is de vraag aan welke woorwaarden een thesaurus moet voldoen om opbrengst en precisie optimaal te doen zijn. In elk geval is de precisie afhankelijk van de mate van specificiteil van de descriptoren die in een thesaurus zijn opgenomen ${ }^{741}$ : hoe specifieker de descriptoren, des te minder irrelevante documenten worden er gevonden. De precisie wordt nadelig beïnvloed door een ruime extensie van de descriptoren ${ }^{742}$. Om dit met cen voorbeeld ${ }^{743}$ te verduidelijken: als in een thesaurus 70 documenten over damesfietsen en 30 documenten over herenfietsen gaan, zou de ruimere term 'fietsen' 100 documenten opleveren. De gebruiker van de thesaurus die uitsluitend is geïnteresseerd in documenten over damesfietsen, kan de irrelevante documenten over herenfietsen bij voorbaat uitsluiten met de meer specifieke descriptor 'damesfietsen' indien meer specifieke descriptoren voor herenfietsen en damesfietsen zijn toegekend. Dat is niet mogelijk als 'damesfietsen' en 'herenfietsen' slechts non-descriptoren zijn omdat deze woorden synoniemen worden geacht voor 'fietsen'. In het laatste geval is de gebruiker van de thesaurus die uitsluitend is geïnteresseerd in damesfietsen, genoodzaakt om 30 documenten over herenfietsen te schiften uit een vangst van 100 documenten die van de descriptor 'fietsen" voorzien zijn. Een grotere specificiteit van de descriptoren maakt de selectie van de 70 relevante documenten overbodig.

738. Cf. Klatsse, 14:18\% wan de onderzochie titels bleken ofwel gex, of wel onjuiste dan wel onvoldoende informatie te verschaffen ower de inhoud van het betreffende artikel. Overigens kan men evenmin witsluitend afgaan op de woorden in de titels van boeken. Vertullende titels voor wetenschappelijke publicaties moeten uit een oogpunt van betrouwbare communicatie hetzij misteidend hetzij overbodig worden geacht. De precisie wan de vangst kan worden verhoogd door het toevoegen van descriptoren anth de titels.

739. Tapper. 47.

740. Cf. Pălstra 19696, 463. Door consequent "goodwwill" als descriptor toe te kennen kan de opbrengst van een zoekactie worden verhoogd ten opzichte van het zoeken in de volledige tekst van documenten waaraan geen descriptoren zijn toegevoegd.

741. Cf. Aitchison/Gilchrist, 8, 23; cf. Riesthuis/Wijnands, 17.

742. Cf. Grunwald, 27-28.

743. Cf. Van Laer $1987 \mathrm{~b}, 140$. 
Als het raadplegen van een thesaurus is geautomatiseerd, beschikt de gebruiker over faciliteiten om de opbrengst en de precisie van zijn zoekactie te bepalen. Truncatie verhoogt de opbrengst van een zoekactie ${ }^{74}$ indien daarmee wordt woorkomen dat relevante documenten ten onrechte buiten de gevonden verzameling vallen. Om het voorbeeld van $\$ 2$.A te hernemen: de gebruiker die in diverse aspecten van het bibliotheekwezen is geïnteresseerd, kan na truncatie zoeken naar alle documenten met descriptoren die beginnen met BIBLIOT\#. Als een gebruiker van een thesaurus geinteresseerd is in bibliotheekcollecties in het bijzonder, kan hij met truncatie ook de precisie van zijn zoekresultaat verhogen door slechts die meer specifieke descriptor te kiezen. Verder kan met de logische operator ' $O F$ ' de opbrengst en met 'EN' de precisie worden verhoogd ${ }^{745}$. Een ander voorbeeld uit $\$ 2$.A illustreert dit: de logische operator ' $E N$ ' beperkt de opbrengst van de zoekactie, maar verbetert de precisie ervan als men zoekt naar documenten over de universiteit te Maastricht.

Als men drie descriptoren met ' $E N$ ' combineert in een zoekactie, wordt de precisie nog eens vergroot; de opbrengst nog eens verminderd. Bovendien wordt de precisie in sterkere mate verhoogd wanneer de logische operator 'EN' wordt toegepast op specifie$k e$ in plaats van op ruime descriptoren ${ }^{746}$. Wanneer de gebruiker van de thesaurus een dergelijk resultaat niet wenst, dient hij anders te werk te gaan: de logische operator 'OF' heeft het omgekeerde effect als dat van 'EN'. Met de logische operator 'OF'. kan de opbrengst van de zoekactie worden vergroot en de precisie ervan worclen verminderd. Dit geldt a fortiori als de logische operator ' $O F$ ' wordt toegepast op een aantal getrunceerde descriptoren. Daarmee is toegelicht dat ook van de gebruiker afhankelijk is of een geautomatiseerde thesaurus een optimale opbrengst en precisie biedt. Daarnaast is van belang of de thesaurus specifieke descriptoren bevat.

\section{De juridische thesaurus}

\section{A. SELECTIE VAN RECHTSTERMEN}

Als een thesaurus wordt samengesteld voor juridische documenten, moeten er woorden uit de natuurlijke taal geselecteerd worden om te voorzien in descriptoren. Dit levert

744. Aitchison/Gilchrist, 8, 64; of. Riesthuis/Wijnands, 19.

745. Aitchison/Gilchrist, 63; Riesthuis/Wijnands, 19.

746. Cf. Van Laer $19876,141$. 
problemen op voor de samenstelling van een juridische thesaurus. De gebruiker van een juridische thesaurus werwacht dat deze rechtstermen bevat: hij wil zijn zoekactie naar documenten omtrent een rechtsbegrip gestalte geven in rechtstermen. Dit leidt tot de vraag waarin rechtstermen zich onderscheiden van andere woorden. Op deze vraag kan niet als antwoord worden gegeven dat juridische documenten uitsluitend rechtstermen bevatten zodat daaruit zonder meer kan worden geput voor de samenstelling van een juridische thesaurus. Niet alle woorden in juridische teksten zijn geschikt als descriptoren voor de weergave van rechtsbegrippen. Uit juridische documenten zullen rechtstermen geselecteerd moeten worden, geen woorden uit de omgangstaal. Voor die selectie kan het volgende algemene criterium worden gehanteerd; slechts die woorden die een jurist gebruikt in een betekenis die afwijkt van die in de gewone taal, kunnen rechtstermen worden genoemd ${ }^{747}$. De overige woorden behoeven niet te worden opgenomen in een juridische thesaurus, ook al staan die woorden in juridische documenten ${ }^{748}$.

De afbakening van rechtstermen ten opzichte van de omgangstaal is niet problematisch voor termen die uitsluitend in het juridische spraakgebruik voorkomen zoals 'toerekeningsvatbaarheid', maar met dergelijke woorden is de juridische terminologie geenszins uitgeput ${ }^{749}$. De selectie van rechtstermen levert moeilijkheden op in het geval van uitdrukkingen die zowel tot de rechtstal als tot de algemene omgangstaal behoren zoals "contract' ${ }^{750}$ en 'echtscheiding ${ }^{755}$. Dergelijke termen worden binnen de rechtstaal in een andere betekenis gebruikt dan daarbuiten ${ }^{752}$ : ze hebben voor de jurist een meer specifieke betekenis dan voor de leek ${ }^{753}$. Het onderscheiden van deze betekenissen is problematisch indien algemeen gangbare woorden binnen de rechtstaal worden voorzien van betekenisnuances ${ }^{754}$. Dan is het voor de precisie van de descriptoren van belang dat de samensteller van een thesaurus telkens nagaat of het gaat om rechtstermen of om woorden uit de omgangstaal. Daartoe dient hij zich af te vragen om welke redenen een begrip door de rechtswetenschap wordt gedefinieerd in afwijking van het gewo-

747. Van den Bergh, 33 .

748. Cf. Mazer 1986b, 28.29.

749. Van den Bergh. 33.

750. Cf. Jolowice, 4.

751. Knapp, 276; cf. Knapp, 277; ef. Wan den Bergh, 33; cf. Weston, 18.

752. Loth 1987,359 .

753. Cf. Jettinghoff, 387. Het versehil tussen rechtstaal en omgangstaal kan belangrijke conseguenties hebben, zoals moge blijken uit een Conclusie wan AG Moons (HR 19-10-1965, Nederlandse Jurisprudentie 1970 no. $324, p .921$ ): de mededeling "iemand vernoord te hebben "die is gedaan in de dagelijkse omgangstal, impliceert niet de opzet gericht op het doden wan het slachtoffer.

754. Cf. Van Waelsden, 2. 
ne spraakgebruik ${ }^{755}$. Het kan aanbeveling verdienen om de beoogde betekenis van de descriptor toe te lichten ${ }^{756}$ als termen niet uitsluitend in het juridische spraakgebruik optreden.

Een tweede probleem bij de selectie van descriptoren voor een juridische thesaurus betreft de keuze van de documenten waaraan de rechtstermen ontleend moeten worden. Omdlat een descriptor een courant woord moet zijn $^{757}$, is het aanvaardbaar ${ }^{758}$ on descriptoren te selecteren uit de rechtstermen in de documenten waarop de thesaurus zal worden toegepast ${ }^{759}$. Wetgeving of jurisprudentie kunnen het heersende taalgebruik bevatten; daarbij moet de samensteller van een juridische thesaurus bedacht zijn op bijzondere problemen.

De selectie van eenduidige woorden uit wetgevingsdlocumenten kan worden bemoeilijkt door het gebruik van meerduidige woorden om verschillende politieke partijen te verzoenen ${ }^{760}$. Door de noodzaak om compromissen te sluiten in de wetgevende vergadlering wordt wetgeving onder meer een middlel om groepsconflicten te verzachten zodat de wetgever er niet in slaagt een maximum aan helderheid en eenvoud in de tekst te leggen ${ }^{761}$. Bovendien kunnen wijzigingen in de wetgevingsterminologie problemen veroorzaken wanneer oude termen niet meer herkenbaar zijn voor een modern publiek $^{762}$. De selectie van descriptoren uit jurisprudentie kan problematisch zijn wanneer deze documenten veel synoniemen bevatten, zoals het geval is voor rechterlijke uitspraken die in het Verenigd Koninkrijk worden gedaan ${ }^{763}$. Dan is problematisch

755. Ledig, 326; cf. Von Jhering, 332 noot 482. Overigens zullen redenen voor de afwijking wan het uniforne sprazkgebruik nict expliciet geformuleerd zijn indien de regelgever zich niet bewust is van dat spraakgebruik: of. Gusy, 219. Als de regelgever zich bewust moet zijn van dreigende afwijkingen van thet normale spraakgebnik is het de vrage of hij zich aan de betreffende alanwijzingen houdt. Zite Borman, 47: (54.1) Het normate spraakgebruik wordt zoweel mogelijk gevolgd; en Borman, 63: (121.2) In een begripsbepaling wordt aan een term geen sterk van het nornale sprakgebuik afwijken. de betekenis gegeven.

756. Met een 'kwalificatie' of een 'gebruiksomschrijwing': cf. Riesthuis/Wijnands, 46-47.

757. Zile V.81.A.

758. Het is mogelijk on een juridisch document te klasseren met descriptoren die niet in dat document woorkomen maar in andere juridische documenten.

759. Er kunnen ook rechtstermen worden geselecteerd uit wakwoordenboeken, lexica of reeds beschikbare juridische thesauri.

760. Tapper, 47

761. Aubert, 57, 61; cf. Friedman, 90,

762. Corbett, 763 .

763. Tapper, 48. Het stapeler van synoniemen komt ook voor in Engelse en Amerikaanse regrelgewing: Friedman, 90 . 
welk synoniem descriptor moet zijn in verband met het heersende taalgebruik. Bovendien kan door de toepassing van regelgeving een van die regelgeving afwijkende terminologie ontstaan ${ }^{764}$ waarbij de rechtstoepasser impliciete definities hanteert om tegemoet te komen aan het te beoordelen geval ${ }^{765}$. Deze definities in de jurisprudentie kunnen op hun beurt verschillen van de definities waarbij de wetgever afwijkt van het gewone spraakgebruik. Door dergelijke variaties in de rechtstaal ${ }^{766}$ wordt de selectie van rechtstermen bemoeilijkt.

\section{B. POSTCOÖRDINATIE}

Bij de constructie van een thesaunis wordt verondersteld dat pas tijdens de zoekfase descriptoren worden gecombineerd ${ }^{767}$. Met een thesaurus kan een complex onderwerp worden gevonden door te zoeken met een combinatie van descriptoren waarmee elementen van dat onderwerp worden aangeduid ${ }^{768}$. De thesaurus is gebaseerd op het beginsel van 'postcoördinatie'. Dit beginsel impliceert dat de descriptoren van de thesaurus zoveel mogelijk staan voor enkelvoudige begrippen en zo min mogelijk voor samengestelde begrippen ${ }^{769}$. Het beginsel van postcoördinatie leidt tot een zodanige selectie van rechtstermen dat elke descriptor zoveel mogelijk een enkelvoudig rechtsbegrip weergeeft; het opnemen van descriptoren voor samengestelde rechtsbegrippen wordt vermeden ${ }^{770}$. Door de toepassing van het beginsel van postcoördinatie worden de documenten geklasseerd met descriptoren die onafhankelijk van elkaar zijn omdat ze niet op voorhand zijn gecombineerd ${ }^{771}$. Daarbij wordt verondersteld dat de gebruiker van de thesaurus deseriptoren in elke volgorde kan combineren met de logische operator ' $E N$ ' om een samengesteld rechtsbegrip weer te geven. Wanneer naar een samengesteld begrip wordt gezocht moeten de descriptoren tijdens de zoekfase worden gecombineerd; daarbij is het aantal combinaties in beginsel onbeperkt. Het is echter de vraag in welke mate een juridische thesaurus kan worden geconstrueerd volgens het beginsel van post-

764. Cf. Tapper, 48 .

765. Gisy, 218. Daarbij zou een onderscheid gematkt kunnen worden tussen vaste jurisprudentie met uitgekristalliseerde definities enerzijds, en jurispnudentie die neer op het geval in kwestie is toegesneden anderzitds. Cf. Palstra 1969a, 997, 999: de afbakening wan vage begrippen zoals "goede trouw" bleek problematisch in het betreffende computerproject. Het probleem is dat de betekenis van dergelijke vage terinen wordt bepaald voor verschillende situaties; of. Hage 1981, 710.

766. Cf. Engelien, 102: het wordt betwijfeld of een standardisering van de juridische vaktaal kan slagen.

76\%. Voorbij, 204; cf. Riesthuis/Wijnands, 59.

768. Riesthuis/Wijnands, 14 .

769. $\mathrm{Cf}$. Nederlandse Classificatie Stichting. 10, 14.

770. Dalamee wondt de omvang van de thesaurus beperkt: cf, Riesthuis/Wijnands, 140.

771. Aitchison/Gilctirist, 62 . 
coördinatie. Een grotere mate van postcoördinatie leidt tot minder specifieke descriptoren ${ }^{72}$ zodat een beperking tot de weergave van enkelvoudige begrippen de precisie $^{73}$ van de thesaurus nadelig kan beînvloeden. Om die reden dient telkens de vraag te worden gesteld of rechtstermen gesplitst kunnen worden in afzonderlijke woordelementen. Dit probleem zal hierna worden toegelicht, eerst aan de hand van Nederlandse rechtstermen.

De Nederlandse rechtstaal is rijk aan composita of woordsamenstellingen als deze: 'beschikkingsbevoegde', 'servituutgerechtigde', 'terbeschikkingstelling" en 'ondertoezichtstelling' ${ }^{774}$. Als woordsamenstellingen zoals "eigendomsoverdracht" gangbaar zijn in de rechtstaal, verdient splitsing geen aanbeveling ${ }^{775}$. Van de gebruiker van een juridische thesaurus kan niet worden verwacht dat hij in de zoekfase de onafhankelijke descriptoren 'processen' en 'recht' 776 combineert als hij documenten wil vinden over 'procesrecht" 77 . Een splitsing in 'processen' en "recht' doet degene die documenten over 'procesrecht" zoekt ook irrelevante documenten vinden over de onderwerpen 'processen' en 'recht'. Dit is nadelig voor de precisie van de vangst. Door het toepassen van het beginsel van postcoördinatie dreigt bovendien het onderscheid tussen omgangstaal en rechtstaal verloren te gaan ${ }^{778}$ : 'processen' is nauwelijks herkenbaar als de weergave van een rechtsbegrip. Het verdient geen aanbeveling om rechtstermen te splitsen; de splitsing van woordsamenstellingen is ondoelmatig voor de gebruikers van een juridische thesaurus.

Bij het hanteren van postcoördinatie moet worden gewaakt voor een onaanvaardbare vermindering van specificiteit. Een voorbeeld ${ }^{779}$ kan dit illustreren: de rechtsterm 'trust by operation of law' kan in een juridische thesaurus met de descriptor 'trust by operation of law' worden weergegeven. Volledige postcoördinatie zou ertoe leiden dat pas in de zoekfase de combinatie van de drie descriptoren 'trust' EN 'operation' EN

772. Cr. Aitchison/Gilehrist, 8-9, 24; of. Riesthuis/Wijnands, 17: meer precoordinatie vergroot de precisie.

773. Zie V.\$2.B.

774. Van den Bergh, $52-54$.

775. Cf. Riesthuis/Wijnands, 81-82; cf. Weinberg, 26.

776. Weliswaar is het meervoud uitgangspunt woor een Nederlandse thestums (zie W. 1.A), maar het enkelvoud 'recht' is een toegelaten uitzondering: $\mathrm{cf}$. Riesthuis/Wijmands, $42,56$.

777. Cf. Riesthuis/Wijnands, $41,62$.

778. Zie V. 3.A.

779. Knapp, 282. Hij vermeldt hier met aan welk rechtsstelsel zijn voorbeeld is ontleend. Hij beweert hier bovendien dat het probleen van precoördinatie of postcoürdinatie een dilemma oplevert. De overgarig tussen 'precoördinatie' en 'posicoördinatie' is echter veeleer vloeiend omdat er in het algemeen geen scherpe scheiding is te maken tussen enkelvoudige en samengestelde begrippen: cf. Riesthuis/Wijnands, 14-15. 
'law' plaatsvindt. Het afzonderlijk toekennen van deze descriptoren zou ernstig afbreuk doen aan de precisie van de thesauns. Bovendien is 'operation' niet herkenbaar als de weergave van een rechtsbegrip. Een tussenoplossing verdient de voorkeur. Zo kan worden overwogen voor de uitdrukking 'term of years absolute' de woordsamenstelling "term of years" als descriptor te introduceren ${ }^{780}$. Daardoor blijft de rechtsterm 'term of years' herkenbaar als de weergave van een Engelstalig rechtsbegrip voor een gefixeerde periode van enkele jaren. De splitsing in 'term of years' enerzijds en 'absolute' anderzijds is aanvaardbaar omdat de toevoeging van het dagelijkse woord 'absolute" achterwege kan blijven; het woord 'absolute' behoeft niet opgenomen te worden in de thesaurus ${ }^{78 !}$.

Gelet op het voorafgaande moet de samensteller van een juridische thesaurus het beginsel van postcoördinatic terughoudend hanteren. Bovendien speelt een rol voor welke documenten ${ }^{782}$ de thesaurus wordt geconstrueerd. Overigens zijn de voorkennis, ervaring en deskundigheid van de gebruiker van een juridische thesaurus van belang bij de selectie van deseriptoren. Wellicht moet er een verschil worden gemaakt tussen een thesaurus die wordt ontwikkeld voor praktijkjuristen en een thesaurus voor wetenschappelijke onderzoekers ${ }^{783}$. Het is dan ook de vraag of eén thesaurus voor alle documenten van hetzelfde rechtsstelsel te realiseren is ${ }^{784}$. Het is a fortiori de vraag hoe er een thesaurus voor meer rechtsstelsels met verschillende rechtstalen samengesteld kan worden. Over de laatste vraag gaat V. $\$ 4$.

\section{\$ 4. Rechtsvergelijkende thesauri}

\section{A. MEERTALIGE THESAURI}

Een thesaurus met descriptoren geselecteerd uit verschillende talen is een meertalige thesaurus ${ }^{785}$. Een rechtsvergelijkende thesaurus behoeft niet meertalig te zijn $^{786}$ en

780. Knapp, 282.

781. Het is annenelijk dat de roevoeging 'absolute' bij 'term of years' de betekenis van 'term of years' thiet wijzigt in de context wan "property".

782. Zie V.\$3.A.

783. Cf. Groll 1974a, 17

784. Cf. Van de Walle, 55: in Nedertand ontbreekt een algemene richtijn voor de ontsluiting van rechtsdocumentatie:

785. 150,3

786. Een rechtsvergelijkende thesauns behoeft niet meertalig te zijn indien deze thesaurus witsluitend is bestemd voor documenten omtrent verschillende rechtsstelsels die dezelfde linguistische taal hanteren. 
een meertalige juridische thesaurus behoeft geen rechtsvergelijkende thesaurus te $\mathrm{zijn}^{787}$. Het is echter onvermijdelijk dat de samensteller van een meertalige rechtsvergelijkende thesaurus wordt geconfronteerd met problemen wan meertalige thesauri. Daarom worden eerst meertalige thesauri met rechtstermen behandeld. Er worden twee vormen van meertalige thesauri onderscheiden: de talen hebben dezelfde status en er zijn descriptoren in verschillende talen ${ }^{788}$; er zijn descriptoren in éen dominante taal met non-descriptoren in andere talen ${ }^{789}$. De tweede vorm blijft hier buiten beschouwing omdat daaraan het gevaar kleeft dat slechts non-descriptoren worden opgenomen die relevant worden geacht voor de thesaurusgebruikers die de dominante taal beheersen. Vervolgens gaat V.\$ 4.B over de termen in de "Index to Foreign Legal Periodicals" die een aanzet tot een meertalige rechtsvergelijkende thesaurus vormen. Onderdeel V. $\$$ 4. C bevat tenslotte criteria voor een optimale rechtsvergelijkende thesaurus.

De presentatie van descriptoren in verschillende talen is nauwelijks problematisch waar identiek geschreven woorden met verschillende betekenissen, onderscheiden kunnen worden met een afkorting voor de taal: zo is "bail(E)" te onderscheiden van 'bail(F)' ${ }^{790}$. Dergelijke afkortingen zijn internationaal aanvaard ${ }^{791}$. De constructie van een meertalige juridische thesaurus levert echter bijzondere problemen op bij de selectie van synonieme descriptoren uit verschillende linguïstische rechtstalen. Als wordt uitgegaan van cen bronversie ${ }^{792}$ in de ene linguïstische taal, is het de vraag welke rechtstermen van een andere linguistische taal als synonieme descriptoren kunnen getden. Synoniemen duiden hetzelfde begrip aan ook al worden deze termen uitgedrukt in verschillende talen ${ }^{793}$. Het eigenlijke probleem bij de samenstelling van meertalige thesauri is de bepaling van het begrip dat weergegeven moet worden in verschillende talen ${ }^{794}$. De relatie tussen de synoniemen moet omkeerbaar zijn. Aan dit vereiste voldoen bijvoorbeeld de Engelse descriptor 'barrister' en de Nederlandse descriptor "advocaat' niet ${ }^{795}$ omdat Engeland ook nog de 'solicitor' als advocaat kent zodat 'barrister'

787. Een meertalige thesaurus die uitshuitend is bestemd yoor de documenten van ten meertalig rechtssysteem zoals dat van Belgie , is niet rechtsvergelijkend.

788. Europees Parlement, 9.

789. Ce. ISO, 3.

790. Het woorbeeld is ontleend an Gutteridge, 118 . Vermelde wijze on onderscheid te maken tussen talvarianten is te vinden bij Aitchison/Gilchrist, $113 \mathrm{en} \mathrm{bij} \mathrm{Riesthuis/Wijnands,} \mathrm{155.} \mathrm{'Bail(E)'} \mathrm{kan}$ worden vertaald met borgtocht; 'bail(F)' met huur of pacht.

791. Cf. Dahlberg 1974, 285; cf. Lansky 1982, 25.

792. Cf. Aitchison/Gilchrist 108.

793. Cf. Franken, 69; cf. Loth 1991, 76; of. Sartori, 84.

794. Cf. Jansen, 14-15; cf. Somers, 72.

795. De Groot/Rayar, 529 noot 14. Sarcevic, 278, 282, geeff andere voorbeelden. 
specifieker is dan advocaat'. Synoniemen in meertalige thesauri moeten even specifieke begrippen representeren ${ }^{79}$. Aan de descriptoren in verschillende talen kunnen overigens non-descriptoren worden toegevoegd overeenkomstig de woordenschat van de betreffende taal ${ }^{797}$. Weliswaar worden non-descriptoren niet gebruikt voor documenten of zoekacties, maar ze behoren evenals descriptoren tot de thesaurus ${ }^{798}$. Eventueel wordt er een tussenschakel geïntroduceerd: een uniforme notatie ${ }^{799}$ waaronder alle nationaal-specifieke uitdrukkingen voor eenzelfde begrip worden samengevoegd ${ }^{800}$. Deze notatie kan in de plaats treden voor de nationaal-specifieke uitdrukkingen voor hetzelfde begrip ${ }^{801}$.

De problematiek bij de constructie wan een meertalige juridische thesaurus is niet dezelfde als die bij het samenstellen van een juridisch woordenboek: een meertalige thesaurus heeft een ander doel dan een meertalig vakwoordenboek. Met een thesaurus zoekt men niet de exacte vertalende term, maar documenten waarbij de vangst niet $100 \%$ precies kan zijn ${ }^{302}$. Een woordenboek beschrijft geen synoniemen maar verdedigt bet woordgebruik dat de voorkeur verdient ${ }^{803}$. Een juridisch woordenboek bevat eventueel verschillende vertaalsuggesties die voor de tekst in kwestie overwogen kunnen worden ${ }^{804}$. Daarentegen worden verschillende betekenissen van een term in een thesaurus opzettelijk beperkt met het oog op het terugvinden wan documenten ${ }^{805}$. De keerzijde daarvan is dat een meertalige thesaurus niet als een vakwoordenboek gebruikt kan worden. Het principiële verschil tussen een meertalige thesaurus en een woordenboek is juist dat een thesaurus niet beoogt wreemdtalige begrippen uit een tekst volstrekt exact te vertalen in een synonieme term ${ }^{806}$. Dit verschil wordt toegelicht met het volgende voorbeeld: een woordenboek kan 'kolchosnoe pravo' onder meer vertalen in 'Kolchosrecht'; een thesaurus dient slechts 'LPG-recht' 8107 als equivalent te geven. Het woordenboek verwijst dan met een Duitstalig woord naar Russisch recht omtrent collectieve

796. Het abstractieniveau moet hetzelfde zijn: zie III.84.B (slot) ten anzien van nieuwe temen.

797. Europees Parllement, 9, 13.

798. Zie V. 1.A.

799. Deze notaties vormen een 'Umschaltsprache'; cf. Svenonius 1979, 205, 210: 'switching language".

800. Anders, 96; of. Neville, 621: met de notatie kan het begrip geïdentificeerd worden.

801. De nationale begripskenmerken moeten dus geidentificeerd zijn: of. Dahlberg 1981a, 19. Vervolgens kan het begrip worden vervangen door de notatie die het begrip representeert: Dahtberg $1974,115$.

802. Cf. Linant de Bellefonds, 707:

803. Cf. Mackaay, 54. Bovendien bevat en woordenboek zelden hiërarchische relaties. Een thesaurus is beschrijvend: Didier, 356. Cf. Didier, 352-353; ten aanzien van juridische woordenboeken.

804. Cf. De Groot 1990a, 24; cf. De Groot 1990b, 128

805. Ct. Aitchison/Gilchrist, 12.

806. Anders, 96.

807. "LPG" is de afkorting voor: "landwirtschaftliche Produktionsgenossenschaft". 
economie, de thesaurus voorziet in een Duitstalige pendant in de vorm van een rechtsterm van de voormalige DDR. Dankzij de descriptor 'LPG-recht' kan de thesaurusgebruiker met een term van zijn eigen rechtsstelsel overeenkomstige documenten terugvinden met betrekking tot het Russische recht.

Een meertalige thesaurus legt synoniemen in verschillende rechtstalen vast. In een meertalige thesaurus moeten alle synoniemen van elke taal corresponderen ${ }^{808}$ "Synoniemen zijn volgens Knapp ${ }^{809}$ corresponderende uitdrukkingen met betrekking tot dezelfde of zeer gelijkende rechtsinstellingen in verschillende rechtssystemen. Daartoe behoren volgens hem de volgende uitdrukkingen voor de wettelijke erfgenaam die zijn wettelijk erfdeel ${ }^{810}$ niet kan worden onthouden bij testament: 'réservataire' in het Franse recht, 'Pflichtteilsberechtigter' in het Duitse en Zwitserse recht, 'Noterbe' in het Oostenrijkse recht en 'heredero forzoso' in het Spaanse recht. Dergelijke synoniemen moeten volgens Knapp ${ }^{811}$, worden onderscheiden van quasi-synoniemen: uitdrukkingen met betrekking tot rechtsinstellingen die niet geheel identiek zijn doch zozeer gelijkend dat de uitdrukkingen voor die rechtsinstellingen ten behoeve van een nuttige simplificatie ${ }^{812}$ equivalent worden verklaard. Het voorbeeld van Knapp leidt echter tot de vraag of daarin niet veeleer sprake is van quasi-synoniemen: er is een verschil tussen het Duitse en Oostenrijkse recht enerzijds en het Franse, Zwitserse en Spaanse recht anderzijds. Er zijn opmerkelijke verschillen qua inbreuk op de beschikkingsvrijheid van de erflater ${ }^{81.3}$. Anders dan in het Franse, Zwitserse en Spaanse recht bestaat er in het Duitse en Oostenrijkse recht slechts een verbintenis om uit de nalatenschap een geldbedrag aan bepaalde wettelijke erfgenamen te betalen; deze wettelijke erfgenamen is in beide rechtsstelsels niet een deel van de erfenis gegarandeerd waarover de erflater niet mag beschikken ${ }^{814}$. Volgens het Duitse en Oostenrijkse recht heeft bedoelde wettelijke erfgenaam een aanspraak op een aandeel in de waarde van de nalatenschap ${ }^{815}$. Het voorbeeld van Knapp Jaat zien dat zijn criteria voor de grens tussen synoniemen en

808. Somers, 72

809. Knapp, 280.

810. Coene/Geelhand, 20 en noot 5 , zien "voorbehouden erfdeel" als een meer neutrale term.

811. Knapp 281.

812. Equivalentie wordt hier pragmatisch benaderd. Dit is conform de opwatting wan Kisch, 209. Deze opvating is echter onbevredigend voor vertalingen van juridische terminologie, ondat bijvoorbeeld de echtscheidingsgronden en het huwelijksvermogensrecht kunnen verschillen zodat een absolute begripsequivallentie voor 'echtscheiding' ontbreekt: De Groot 1990b, 124, Cf. De Groot 1990a, 22: een pragmatische beslissing is gericht op een of ander doel.

813. Coene/Geelhand, 35.

814. Ferid/Firsching, Grundzuge sub F resp. Texte A I voor Spanje.

815. Mellema, 142-143. 
quasi-synoniemen niet in alle gevallen gemakkelijk zijn te hanteren ${ }^{816}$. Dit lijkt geen bezwaar omdat de equivalentie van quasi-synoniemen voor het doel van een thesaurus geponeerd kan worden ${ }^{517}$. Het achterwege laten van onderscheidingen zoals ten aanzien van de wettelijke erfgenaam in het voorbeeld van Knapp vermindert echter de specificiteit van de descriptoren en daarmee de precisie van de thesaurus ${ }^{818}$. Deze onderscheidingen zijn niet zonder meer overbodig voor een meertalige thesaurus.

Het beginsel van postcoördinatie waarop de constructie van een thesaurus is gebaseerd, vraagt om bijzondere aandacht in het geval van een meertalige thesaurus. Bij de constructie van een meertalige thesaurus doet zich het probleem voor dat de splitsing van woordsamenstellingen niet voor éen rechtstaal afzonderlijk kan worden bezien, maar slechts in samenhang met de andere rechtstalen van die thesaurus. De samenhang met de andere talen geeft in een meertalige thesaurus eerder aanleiding tot een parallelle splitsing die met het voorbeeld ${ }^{819}$ van de Duitse woordsamenstelling 'Lehrerbildungsgesetz' geilllustreerd kan worden:

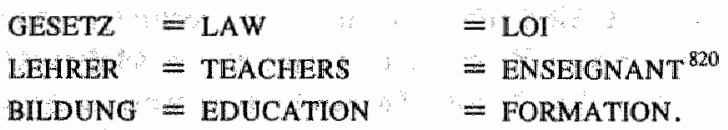

Met de splitsing van 'Lehrerbildungsgesetz' worden ongeschikte vertalingen als 'Law of education of teachers' en 'Loi sur la formation des enseignants' vermeden ${ }^{821}$; 'Lehrerbildungsgesetz' kan als non-descriptor worden opgenomen ${ }^{822}$. Met de splitsing van 'Lehrerbildungsgesetz' wordt het probleem opgelost dat een overeenkomstige woordsamenstelling ontbreekt in andere talen. Ook Anders ${ }^{823}$ beveelt aan om woordsamenstellingen zoveel mogelijk te splitsen voor meertalige thesauri. Ondlanks dit uitgangspunt moeten woordsamenstellingen in een aantal gevallen gehandhaafd blijven. Dit geldt bijwoorbeeld voor de woordsamenstelling die een courant rechtsbegrip weergeeft dat gebruikt wordt ter aanduiding van een rechtsgebied of een thema van een groot

816. Dat geldt ook voor het onderscheid ussen exucte equivalentie en onnauwkeurige equivalentie bij Aitchision/Gilehrist, 109 .

817. Zie V.\&1.A.

818. Zie V.s.2. B.

819. $1 \mathrm{SO}^{3} 3$

820. Deze Franse descriptor moet blijkbaar in het enkelvoud geredigeend worden.

821. $150,2$.

82. Somers, 70.

823. Anders, 97. 
aantal documenten ${ }^{\$ 24}$. Op deze uitzondering moet worden gelet in het geval van een rechtsvergelijkende thesaurus.

\section{B. De Index to Foreign Legal Periodicals}

De 'Index to Foreign Legal Periodicals' (IFLP) is een onovertroffen ${ }^{825}$ bibliografie voor het toegankelijk maken van tijdschriftartikelen ${ }^{826}$ die onderwerpen bevatten met betrekking tot verschillende rechtssystemen. De IFLP is beperkt tot de rechtssystemen van andere landen dan die van de Verenigde Staten, de Britse eilanden en het Britse Gemenebest; met deze omschrijving wordt het common law in beginsel uitgesloten ${ }^{827}$. Dit impliceert dat de IFLP tijdschriftartikelen die uitsluitend de common law betreffen, niet toegankelijk maakt tenzij die gaan over de perifere common law. Men kan zeggen dat de IFLP een bibliografie is die het Anglo-Amerikaanse recht buiten beschouwing laat.

Ofschoon Steiner ${ }^{828}$ meldt dat een poging is gedaan om voor de IFLP een meertalige thesaurus samen te stellen, bevat de IFLP geen thesaurus ${ }^{829}$, laat staan een meertalige thesaurus met descriptoren in verschillende talen. In de zoekleiding wordt geen duidelijk onderscheid gemaakt tussen hiërarchische relaties enerzijds en associatieve relaties anderzijds ${ }^{830}$ zodat er geen sprake is van een thesaurus ${ }^{834}$; omdat het Engels de dominante taal is ${ }^{832}$, is er evenmin sprake van een meertalige thesaurus ${ }^{833}$. Niettemin zijn er interessante beschouwingen gewijd aan de selectie en de redactie van termen die

824. Anders, 97.

825. Gödan $1992,167$.

826. Bronmenpublicaties zoals overheidspublicaties en jurisprudentieperiodieken worden niet onitsloten door de IFLP: Godan 1992, 148. Deze beperking is geen bezwaar indien het juist is dat de andacht van de rechtswergelijkende onderzoeker primair uitgaat natr literatutur en dahrna pas naar regetgeving of jurisprudentie: cf. Gớdan 1986, 4, 39.

827. Reynolds/Kenefick/Durkin 1991: 'Editorial policies and subscription information'; ef. Godan 1992. 143; cf. Reynolds, 139.

828. Steiner $1977,858$.

829. De IFLP is op CD-ROM beschikbaar en daarmee kan er geautomatiseerd worden gezoch met de termen wan de IFLP. Dit impliceert ecliter niet datt de IFLP en thesaums bevat: de termen die de iijdschriftartikelen toegankelijk maken, zijn noch geselecteerd noch gerelateerd met het oog op genutomatiseerd zoeken.

830. Zie V.81.A.

831. Cf. Riesthuis/Wijnands, 34-35.

832. Reynolds, $138,140,142$.

833. Zie V. 4.A. 
de IFLP gebruikt om tijdschriftartikelen toegankelijk te maken. Deze beschouwingen vormen een aanzet tot een meertalige rechtsvergelijkende thesaurus.

De selectie van termen voor de IFLP is problematisch gebleken. Zo signaleert Steiner ${ }^{834}$ dat begrippen geëigend voor het ene rechtssysteem ongeschikt zijn voor een verschillend rechtssysteem of een andere rechtsfamilie. De oplossing voor dit probleem werd gezocht in het zoveel mogelijk gebruiken van generieke termen. Generieke termen worden omschreven als technische termen die voldoende onderscheidingen missen om van toepassing te zijn op rechtsinstellingen die een globale gelijkenis in functie en doel vertonen terwijl hun essentiêle aard van rechtssysteem tot rechtssysteem verschilt. Steiner laat echter in het midden wat hij verstaat onder de essentiële aard van reclitsinstellingen; het gaat blijkbaar om toonaangevende eigenschappen die niet worden onderscheiden met generieke termen. Elders geeft Steiner ${ }^{835}$ een enigszins afwijkende omschrijving van generieke termen: termen die een object of een groep van objecten aanduiden met een klasse waarbij het gebruik van de specifieke terminologie van een land achterwege wordt gelaten. Noch de functie noch het doel van rechtsinstellingen worden in deze laatste omschrijving genoemd.

Het eerste voorbeeld van een generieke term dat Steiner ${ }^{836}$ geeft; is 'adoption' waarbij het volgens hem gaat om een begrip dat in vele rechtsstelsels een zodanige gelijkenis vertoont dat de vertaling van deze term niet leidt tot een gebrek aan precisie of tot enige vervorming. Toch is 'adoption' geen synoniem, althans niet voor de rechtsstelsels die uitsluitend de zwakke adoptie ${ }^{837}$ kennen: de rechtsterm 'adoption' van het Engelse rechtsstelsel is slechts synoniem met de sterke adoptie. Een tweede voorbeeld van een generieke term is volgens Steiner ${ }^{838}$ 'judicial review of administrative acts' omdat deze term niet alleen geschikt is voor de activiteiten van bijzondere administratieve rechtbanken zoals de Franse 'conseil d'état', maar ook voor de procedure in Engelse rechtbanken die wordt ingeleid met 'prerogative orders' ${ }^{339}$. Daardoor wordt er geen rekening gehouden met de omstandigheid dat in landen als Groot-Brittannië de conceptuele tegenhianger van de Franse "conseil d'état' ontbreekt ${ }^{840}$. In het tweede voorbeeld

834. Steiner $1973 b, 54$; cf. Steiner $1977,858,861$.

835. Steiner 1974a, 8, gelijkluidend aan de veel oudere passage bij Stern, 310 .

836. Steiner 1977,859 .

837. Zie thoofdstuk I.

838. Steiner $1973 b, 54 ;$ ct. Steiner $1974 a, 8$.

839. Te vertalen met: beslissing van de overheid. Overigens is het opvallend dat Steiner hier het Engelse recht in zijn voorbeeld betrekt, omdat de IFLP het Engelse recht niet ontsluit tenzij het om rechtswergelijkende publicaties gaat.

840. Cf. Koopmans, 6. 
gaat het volgens Steiner om activiteiten ${ }^{841}$ die gericht zijn op hetzelfde doel zodat eén generieke term volstaat. Weliswaar is er een essentieel verschil tussen de Engelse 'Crown proceedings' enerzijds en de 'contentieux administratif' of de 'Verwaltungsgerichtsbarkeit' anderzijds, maar de functie van deze procedures, die tot verschillende rechtsfamilies gerekend moeten worden, is volgens Steiner ${ }^{842}$ identiek. De IFLP vat deze procedures samen met de generieke term "judicial review of administrative acts $^{243}$. De toelichting van Steiner geeft aan dat deze nieuwe woordgroep ${ }^{844}$ is ge formuleerd vanuit de functie van de verschillende rechtsinstellingen ${ }^{845}$. De generieke term 'judicial review of administrative acts' is echter te ruim voor degene die slechts op zoek is naar documenten over de "conseill d'état' ${ }^{846}$.

De termen van de IFLP zijn niet alleen generieke termen. Het gebruik van generieke termen is volgens Steiner ${ }^{847}$ beperkt in verband met instellingen en begrippen die dermate verschillend zijn dat ze niet passen in de klassen waarop de generieke termen het oog hebben. Het gebruik van generieke termen vindt zijn grens in verschillen tussen rechtsstelsels die niet met generieke termen verzoend kunnen worden zonder dat er vervorming optreedt. Zo kan de term 'rule of law' niet worden gebruikt voor de communistische versie ervan omdat dit laatste begrip volledig verschilt van de "rule of law" in de westerse landen ${ }^{848}$; derhalve werd in de IFLP de term 'socialist legality" geïntroduceerd met een zie-verwijzing naar onder meer 'rule of law'. Daardoor kan de niet-generieke term 'rule of law' toch worden toegepast op communistische landen.

De Engelstalige termen van de IFLP zijn vertaald in Franse, Duitse en Spaanse termen. Daarbij bleek de vergelijking van de taalversies een aantal voordelen te bieden: dankzij de vertalingen werden er inconsistenties ontdekt en werden extensie en intensie van de

841. Die activiteiten worden niet onderscheiden: cf. Gödan $1992,150$.

842. Steiner $1974 a, 8$.

843. Een consequentie van deze formulering zou overigens de keuze van de volgende parallei kunnen zijn: "judicial review of private acts".

844. De samenstellende woorden zijn niet nieuw maar de woordgroep alls zodanig: of. Weston, 28. Cf. Mazet 1986b, 15: de betekenis van een begrip zonder pendant kan wellicht worden betiaderd met een korte woordgroep. De nieuwe woordgroep verschilt echter nauwelijks van de volgende woordgroep die tot de rechtstaal wan het Engelse rechtsstelsel behoort: "judicial review of administratswe action" ,

845. Leser 1961,461 , ziet de functionele benadering als oplossing voor het probleem wan het ontbreken van een terminologie waarmee de onderscheidingen van de nationale rechtshegrippen geneutraliseerd zouden kunnen worden. De selectie van termen woor de IFLP zou deze functionele benadering dienten te volgen. Uit het bovenstaande blijke dat in de IFLP daamaar wordt gestreefd: et. Godan 1992, 159 .

846. Steiner $1977,859$.

847. Siteiner $1974 a, 8$.

848. Steiner 1977, 859; cf. Groll 1974b, 29. 
geselecteerde termen preciezer ${ }^{849}$. Er was sprake van correcties over en weer ${ }^{850}$. De niet-Engelstalige termen verwijzen telkens naar Engelse termen waarmee de tijdschriftartikelen toegankelijk worden gemaakt. Op de overheersende positie van de Engelse taal is echter kritiek geuit. David ${ }^{85}$ acht de dominantie van de Engelse termen een nadeel omdat de Engelse taal word gebruikt voor de common law; hij geeft de voorkeur aan Franstalige termen omdat het Frans beter wordt begrepen door continentale juristen. Zijn kritiek kan worden aangevuld met het volgende voorbeeld: de Engelstalige term 'legitimate portion' is in de IFLP vertaald met de Franstalige term "réserve héréditaire", de Duitstalige term 'Pflichtteil' ${ }^{852}$ en de Spaanstalige term "porción legítima'. Daarbij maakt de term 'legitimate portion' deel uit van de omvattende term "family provision' ${ }^{853}$. Deze rubricering in de IFLP is echter misleidend omdat het Engelse recht in de "family provision" weliswaar een indirecte beperking van de testeervrijheid kent, doch geen directe beperking door een wettelijk erfdeel, ook niet in de gemitigeerde vorm van het Duitse of Oostenrijkse recht ${ }^{854}$. Het Engelse recht laat de erflater in principe volkomen vrij, maar onderhoudsbehoeftige verwanten hebben een aanspraak op geld ter verzekering van hun onderhoud ${ }^{855}$. De gebruiker van de thesaurus van de IFLP dient zich ervan bewust te zijn dat de Engelstalige rubriek 'family provision' staat voor een erfrechtelijk begrip dat het Engelse rechtsstelsel niet kent ${ }^{856}$. Daartoe dient de ruimere term 'inheritance' die boven de term 'family provision' is opgenomen in het systematisch register bij de IFLP ${ }^{857}$ : met deze hiërarchische relatie wordt aangegeven dat vermelde term in het erfrecht is te situeren. Deze hiërarchische relatie fungeert in de IFLP als een toelichting op de betekenis van een Engelstalige term die geen Engels rechtsbegrip weergeeft. Deze toelichting zou overbodig zijn als de tijdschriftartikelen met de continentale rechtsterm 'réserve héréditaire' toegankelijk gemaakt zouden worden.

849. Steiner $1973 b, 55 ;$ ef. Steiner 1977,857 .

850. Cf. Aitchison/Gilchrist, 109; cf. Riesthuis/Wijnands, 152.

851. David 1960, 235.

852. Door Kreuzer, 145, is een neutrale vervangende omschrijving voorgesteld: 'Beschränkungen des Erblassers bei Verfügungen won Todes wegen zugunsten bestimmter Personen ( $z$.B. Ehegatten)'.

853. Reynolds/Kenefick/Dumkin $1991,41,110,116,132$.

854. Zie V. 4.A an Coene/Geellwand 22 ; Ferid/Firsching, Grundzöge sub F XII tw. . Engeland; cf. Herbots, 318.

855. Mellema, 143.

856. De Engelse "family provision" heeft vooral een alimentatieve functie: of. Coene/Geelhand, 31 ; of. Margrave, 205, 212, 218, 229.

857. Reynolds/Kenefick/Durkin 1991, 41. De 'Systematic arrangement' is overigens niet bestemd voor juristen die gevefend zijn in de common law: Gödan 1992, 161; Reynolds, 139-140. 


\section{RECHTSVERGELUKENDE THESAURI}

Met een rechtsvergelijkende thesaurus moeten documenten teruggevonden kunnen worden die voldoen aan buitenlandse begrippen die corresponderen met de begrippen van bijvoorbeeld het Nederlandse rechtssysteem. Daarbij mag geen belemmering zijn dat de Nederlandse jurist de buitenlandse rechtstaal niet of nauwelijks kent ${ }^{858}$. Wanneer een Nederlandse jurist documenten wil terugvinden omtrent een rechtsstelsel dat een andere linguïstische taal hanteert, is hij gebaat bij een meertalige rechtsvergellijkende thesaurus. De termen van de IFLP zijn weliswaar meertalig, maar vormen tezamen geen meertalige thesaurus ${ }^{859}$. Toch vormen de termen van de IFLP een bescheiden aanzet tot een rechtsvergelijkende thesaurus die voor meer rechtsstelsels bruikbaar is ${ }^{860}$. De generieke termen van de IFLP zouden een bijdrage kunnen leveren aan het wegnemen van terminologische belemmeringen waarmee rechtsvergelijkende onderzoekers worden geconfronteerd ${ }^{861}$. Volgens Steiner ${ }^{862}$ zouden de termen van de IFLP een waardevol conceptueel instrument voor rechtsvergelijkende onderzoekers kunnen worden mits aan drie voorwaarden wordt voldaan: er worden meer vertalingen gerealiseerd, de termen worden verder verfijnd en er wordt voldaan aan de vereisten van alle rechtsstelsels. Daaruit is af te leiden dat deze termen volgens Steiner onvoldoende precies zijn. Dit roept de vraag op: kan een zodanige thesaurus worden geconstrueerd dat de overeenkomsten en de verschillen waarin de rechtsvergelijkende onderzoeker geînteresseerd is, teruggevonden worden ${ }^{863}$ ?

De termen van de IFLP zijn in het Engels geformuleerd om een mondiaal publiek te bereiken. De keuze van de Engelse taal kan echter afbreuk doen aan de precisie. De Engelse taal is niet universeel want er bestaan terminologische verschillen tussen het Engels van het Verenigd Koninkrijk, het Engels van internationale organisaties en het Engels dat buiten het Verenigd Koninkrijk wordt gebezigd ${ }^{864}$. Zo wordt de Ameri kaanse term 'domestic relations' gebruikt naast het Europees-Engelse 'family law' 865 .

858. Zie III.\& 5.B.

859. Zie V. 4.B.

860. Leser 1981, 68. Een universele thesaurus woor alle Europese rechtsinformatie wordteen hersenschim genoemd door Bauer 1982, 254, 260.

861. Stern, 310 .

862. Steiner 1973b, 61; cf. Steiner 1973b, 56.

863. Cf. Steiner 1977, 856.

864. Lehto, 165; cf. Kisch, 214.

865. Kisch, 215. 
In de IFLP ${ }^{866}$ wordt deze Amerikaanse term equivalent verklaard met de EuropeesEngelse term. De term "family law" blijft op deze wijze niet beperkt tot het Engelse rechtsstelsel. De keerzijde daarvan is dat de precisie van de term "family law" geringer is dan die van het Europees-Engelse rechitsbegrip.

De stelling dat descriptoren slechts dan synoniem zijn indien er sprake is van eén rechtstaal en een rechtsstelsel, is te absoluut. Ook in het geval van twee of meer rechtstalen zijn echte synoniemen mogelijk indien de rechtstermen op hetzelfde rechtssysteem betrekking hebben ${ }^{867}$. Zo bestaan in Finland alle rechtsbegrippen in het Fins en in het Zweeds ${ }^{868}$. Voor een meertalig rechtssysteem zoals dat van België kunnen Franstalige en Nederlandstalige descriptoren synoniem zijn. Indien hetzelfde begrip wordt weergegeven, kan een descriptor ongeacht de taalwersie worden vervangen door eenzelfde notatie ${ }^{869}$. Dezelfde notatie is dan de tussenschakel ${ }^{870}$ tussen de descriptoren in verschillende taalversies. Zodra er sprake is van verschillende rechtssystemen is absolute begripsidentiteit echter onmogelijk vanwege de sterke systeemgebondenheid van juridische begrippen ${ }^{871}$. Dit leidt ertoe dat een meertalige rechtsvergelijkende thesaurus geen synonieme descriptoren kan bevatten voor verschillende rechtsstelsels. Er kunnen weliswaar quasi-synoniemen geselecteerd worden, maar hun specificiteit is geringer dan die van synoniemen zodat de vangst van een zoekactie minder precies is ${ }^{82}$. In het geval van quasi-synoniemen ontbreekt een betekenisonderscheid. Bovendien zijn er nationale rechtsbegrippen zonder pendant in een ander rechtsstelsel ${ }^{873}$; dan is er zelfs geen quasi-synoniem beschikbaar.

Het opnemen van quasi-synonieme descriptoren is onontkoombaar door de sterke systeemgebondenheid van de rechtsbegrippen die worden weergegeven. Een meertalige rechtsvergelijkende thesaurus vereist dan ook een grondige bestudering van de verschillende nationale rechtsregels en rechtsbegrippen ${ }^{874}$. In VIL.\$2.B zullen conclusies

866. Reynolds/Kenefick/Durkin 1989, 127. Cf. Reynolds/Kenefick/Durkin 1991, 'Editorial policies and subscription information': de separate lijst van Engelse 'Subject headings and cross references' is woor het laatst verschenen in de cumulatieve edite 1989 wan de UFLP.

867. Cf. Sacco, 29 .

868. Lehto, 164, cf Mincke 1987, 105, 110.

869. Houtart, 16 en Storme, 679 ten aanzien van het Belgische CREDOC.

870. Zie V.8.4.A.

871. Kisch, 209; of. De Groot 1990a, 21, 22, 24.

872. Zie V.\$2.B.

873. Mazet 1986a, 781.

874. Cf. Mazet 1986a, 781-782. 
worden getrokken ten aanzien van rechtsvergelijkende thesauri als toepassingsgebied van comparatieve begrippen. 


\section{Rechtsvergelijkende begripskwalificatie in het IPR}

\section{§ 1. Het kwalificatieprobleem in het IPR}

\section{A. VERWIIZINGSREGELS IN HET IPR}

Het internationaal privaatrecht (IPR) heeft het doel problemen die voortvloeien uit de samenloop van nationale rechtsstelsels bij internationale privaatrechtelijke rechtsverhoudingen, toe te wijzen aan één rechtsstelsel. Het IPR heeft privaatrechtelijke rechtsverhoudingen met een grensoverschrijdende dimensie tot onderwerp. De bronnen van het Nederlandse IPR worden gevormd door een aantal losse wettelijke regelingen, ongeschreven recht en een vrij groot aantal verdragen ${ }^{875}$. Als er geen sprake is van een samenloop van rechtsstelsels heeft het IPR geen taak te vervullen ${ }^{876}$.

Naar Nederlandse opvattingen worden de wolgende drie hoofdonderdelen van het IPR onderscheiden:

a. het internationale bevoegdheids- of jurisdictierecht dat de rechtsmacht van de nationale rechter afbakent;

b. het conflictenrecht dat aangeeft door welke nationale rechtsregels internationale rechtsverhoudingen worden beheerst;

876. Strikwerda, 23. 
c. het recht inzake de erkemning en tenuitwoerlegging van buitenlandse rechterlijke beslissingen ${ }^{877}$.

Uit de drie hoofdonderdelen is af te leiden dat het IPR bestaat uit regels voor feitencomplexen die elementen bevatten die met een buitenlands rechtsstelsel zijn verbonden.

Met het conflictenrecht ${ }^{878}$ van het Nederlandse IPR stelt de Nederlandse rechter vast welke privaatrechtelijke regels hij moet toepassen op een internationaal feitencomplex. Daarbij moeten drie soorten ${ }^{879}$ conflictregels worden onderscheiden:

I. de eenzijdige conflictregel: zwijgt over de eventuele toepasselijkheid van vreemd recht;

II. de meerzijdige conflictregel: staat toepassing van vreemd recht toe zonder een onderscheid te maken tussen eigen en vreemd recht;

III. de materiële of zelfstandige conflictregel: lost het internationale wetsconflict niet op door het te verwijzen naar enig rechtsstelsel doch voorziet zelf in een materiële norm ${ }^{\text {Ban }}$.

De belangrijkste conflictregel is de meerzijdige conflictregel ${ }^{881}$; de uitdrukking 'verwijzingsregel' wordt hierna beperkt tot de meerzijdige conflictregel.

Verwijzingsregels worden toegepast op gevallen als deze: twee Nederlanders zijn gehuwd in Duitsland; dient dit huwelijk in Nederland te worden erkend? Is voor de beantwoording van die vraag het Nederlandse of het Duitse recht beslissend? De Duitse of Nederlandse verwijzingsregels geven aan naar welk nationaal rechtsstelsel het geval moet worden beoordeeld. Voor het geval de Nederlandse rechter wordt geroepen om

877. Strikwerdin, 20-21. Daarbij merkt Strikwerda, 21, op dat het conflictenrecht wel wordt aangeduid als: het nateriële IPR, en dat in Duitsland de term IPR wordt gereserveerd voor het conflictenrecht met uitsluiting van thet formele IPR: het internationale bevoegdhe idsrecht en het internationale erkenningsenl executierech.

878. Hiernd blifft hat renvoiprobleem buten beschouwing. Bij het renvoiprobleen doet zich de wrag voor of bij strijd tussen het eigen en het vreente conflictenrecht, de werking van de eigen conflictregel afgestemd moet worten op de inhoud van het vreemde conflictenrecht: Strikwerda, 85.

879. De semi-publiekrechtelijke voorrangsregels blijven hier buiten beschouwing ondat deze voorschriften ongeacht de verwijzingsregel toepasselijk kunnen zijn; zie Strikwerda, 91.

880. Strikwerda, $45-47$.

881. Audit 1993, 55; cf. Strikwerda, 47. 
de gestelde vraag te beantwoorden, kan hij artikel 5 lid 1 van de Wet conflictenrecht huwelijk ${ }^{882}$ hanteren:

Een buiten Nederland gesloten hwwelijk dat ingevolge het recht wan de Staat waar de huwelijksvoltrekking plaatsvond rechtsgeldig is of nadien rechtsgeldig is geworden, wordt als zodanig erkend.

Volgens deze verwijzingsregel is het van toepassing zijnde recht: het recht van de Staat op welks grondgebied het huwelijk is voltrokken; als het huwelijk volgens dat recht rechtsgeldig is of nadien rechtsgeldig is geworden, wordt dat huwelijk erkend. Bovenstaande verwijzingsregel verwijst de Nederlandse rechter voor dit geval naar buitenlandse privaatrechtelijke wetten. Deze buitenlandse rechtsregels worden ter onderscheiding van de verwijzingsregels 'materiële regels' genoemd. Deze materiële regels kunnen dankzij bovenstaande conflictregel worden geïdentificeerd ${ }^{833}$ : Materiële regels zijn in dit geval de Duitse regels omtrent de wijze van huwelijksvoltrekking en ten aanzien van de huwelijksbevoegdheid ${ }^{884}$. Deze Duitse regels bepalen de rechtsgeldigheid van het aldaar voltrokken huwelijk.

Verwijzingsregels bestaan uit drie te onderscheiden delen ${ }^{885}$. Die drie delen kunnen worden geillustreerd met het bovenstaande voorbeeld uit de Wet conflictenrecht huwelijk:

(1) de verwijzingscategorie: het onderwerp van de verwijzing. Dit onderwerp is een deelgebied van het privaatrecht, bijvoorbeeld "huwelijk" ${ }^{886}$;

(2) de aanknopingsfactor: de norm van de verwijzing. Deze is de spil van de verwijzingsregel: de aanknopingsfactor legt de verbinding tussen de concrete internationale rechtsverhouding en het daarop toe te passen rechtsstelsel ${ }^{887}$. Aanknopingsfactor in het voorbeeld is "plaats van huwelijksvoltrekking";

882. Wet van 7-9-1989, Statsblad 1989, 392; inwerkingtreding 1-1-1990. Artikel 5 lid 1 van de Wet conflictenrecht linwelijk stat in verband met artikel 9 van het Haags Verdrag inzake de voltrekking en de erkemning wan de geldigheid van huwelijken. Volgens artikel 5 lid $\mathbb{v}$ van bedoelde wet komt het Nederlandse recht niet, woor toepassing in aanmerking zodat strikt genomen niet wordt voldan aan het kenmerk van een meerzijdige contlictregel; naat ju ist ondat deze regel uitdrukkelijk handelt over de toepasselijkheid van vreemd recht, is deze regel geen eenzijdige conflictregel, laat staan een materiêle conflictregel.

883. Cf. Dörner, 346.

884. Cf. Strikwerda, 118. Lid 3 wan artikel 5 van de Wet conflictenrecht hw welijk, dat in casu ook nat het Duitse IPR verwijst, blijft in het yoorbeeld buiten beschouwing.

885. Strikwerda, 50 .

886. Strikwerda, 50 .

887. Strikwerda, 51 . 
(3) het als toepasselijk aangewezen rechtsstelsel: het gevolg van de verwijzing ${ }^{888}$. De conflictregel van het voorbeeld verwijst naar 'het recht van de Staat waar de huwelijksvoltrekking plaatsvond".

De samenhang fussen de drie delen van de verwijzingsregel is als volgt: deel (1), de verwijzingscategorie, vormt de toepassingswoorwaarde van het rechtsgevolg ${ }^{899}$ dat in deel (3) is te vinden. Deel (1) bepaalt de toedracht die geconstateerd moet zijn alvorens deel (3) via de aanknopingsfactor in werking kan treden. De aanknopingsfactor leidt naar het rechtsstelsel dat het onderwerp van de verwijzingscategorie zou moeten beheer$\operatorname{sen}^{850}$. Deel (3) leidt echter niet onmiddellijk tot een oplossing van het rechtsprobleem: deel (3) van de verwijzingsregel geeft slechts aan van welke nationale regels de oplossing uiteindelijk moet komen ${ }^{89 !}$. De rechter kan een geschil niet uitsluitend met een verwijzingsregel beslechten. Deel (3) van de verwijzingsregel schrijft voor met welk nationale rechtsstelsel het geschill in verbinding gebracht moet worden. De aanknopingsfactor, deel (2); leidt tot dit voorschrift vanuit de verwijzingscategorie. De aanknopingsfactor bewerkstelligt samen met de verwijzingscategorie het rechtsgevolg van de verwijzingsregel dat het nationale recht waaraan wordt aangeknoopt, moet gelden. De aanknopingsfactor is beslissend voor de toepassing van een rechtsstelsel op een internationaal feitencomplex dat in deel (1) van de verwijzingsregel is omschreven ${ }^{892}$. Het praktische belang van de aanknopingsfactor wordt duidelijk w/anneer de in aanmerking komende verwijzingsregels aanknopingsfactoren met een verschillende inhoud bevatten ${ }^{893}$. De keuze van een verwijzingsregel aan de hand van zijn verwijzingscategorie manifesteert zich dan in een verwijzing die varieert met de aanknopingsfactor zodat telkens een ander rechtsstelsel als toepasselijk wordt aangewezen.

De verwijzingscategorie is van cruciaal belang voor de afbakening en de toepassing van verwijzingsregels. De verwijzingscategorie omschrijft het onderwerp waarvoor de in aanmerking komende materiële regels geïdentificeerd moeten worden ${ }^{84}$. Verwijzingscategorieën bezitten eerder de extensie van een rechtsgebied dan die van een specifiek rechtsbegrip. Een ruime formulering van verwijzingscategorieën is veelal onvermijde-

888. Strikwerdas; 53 .

889. Dörner, 347: het rechtsgevolg behellst een verwijzing naar dat rechtsstelsel dat wà de aanknopingsfactor wordt aringegewen.

890. Downer, 347 .

891. Cf. Rabel 1958, 47.

892. Het is minder juist om met Fikentscher, 777, 779, de aanknopingsfactor tot het rechtsgevolg van de verwijzingsregel te rekemen: diens stankipunt lijkt ingegeven door zijn kritiek op Kegel.

893. Cf. Von Bar, 507.

894. Dörner, 347 . 
lijk, bijvoorbeeld als "huwelijk" 895 . Verwijzingscategorieën geven veeleer vage contouren aan dan precieze grenzen omdat de begrippen van de verwijzingscategorieën de nationale rechter in staat moeten stellen om zich te richten op situaties die zijn beschreven met buitenlandse begrippen ${ }^{896}$. De definitie van de verwijzingscategorie kan niet op voorhand gereduceerd worden tot die van een nationaal of buitenlands rechtsbegrip ${ }^{897}$. De verwijzingscategorie kan niet bij voorbaat worden gereduceerd tot een onveranderlijke definitie. De verwijzingscategorie moet openstaan voor de op voorhand onbepaalbare diversiteit van de verschillende nationale rechtsregels ${ }^{898}$.

\section{B. KWALIFICATIE MET EEN VERWUZINGSCATEGORIE}

De verwijzingscategorie is een deel van de verwijzingsregel. De verwijzingscategorie is een begrip, bijvoorbeeld het begrip 'huwelijk'. Een begrip wordt hier verwijzingscategorie genoemd als het begrip als verwijzingscategorie wordt gebruikt ${ }^{890}$. Kwalificatie aan de hand van een verwijzingscategorie heet dienovereenkomstig 'begripskwalificatie'. Bij het kwalificeren wordt de reikwijdte van het betrokken begrip onderzocht ${ }^{900}$. De kwalificatie aan de hand van een verwijzingscategorie is het middel om te concluderen dat de ene verwijzingsregel wèl en de andere niet toepasselijk is ${ }^{901}$ Verwijzingsregels worden afgebakend na begripskwalificatie. Wanneer er niet gekozen behoeft te worden

895. Knoepfler/Schweizer, 141.

896. Rigaux $1987,319-320$.

897. Esser, 338, 340; cf. Allarousse, 503; cf. Van Ginsbergen 1968, 354; cf. Van Ginsbergen 1970, 1, 8; cf. Weber, 235 .

898. Rigaux 1984. 244.

899. Rigaux 1984, 241; Rigavx 1987, 319. Ook hier is de terminologie niet vast. Voot het Duitse IPR kunnen minstens acht equivalente termen worden opgesomd: Schlosshater, 28 . Owerigens is niet uit te sluiten dat in één yerwijzingscategorie meer begrippen zijn te onderscheiden.

900 . Lemaire, 333.

901. Cf. Lemaire, 332; cf. Mayer, 111 ; cf. North/Fawcett, 44. Meyer, 129, meent dat de kwalificatie is ontwikkeld tot het centrale probleen wan de toepassing van conflictregels. 
tussen verwijzingsregels is er geen kwalificatieprobleem ${ }^{902}$, althans geen kwalificatieprobleem dat een definitieve oplossing vraagt ${ }^{903}$.

Met de verwijzingscategorieën wordt een toedracht, een feitelijke situatie ${ }^{904}$ of een feitencomplex gekwalificeerd: Met kwalificatie wordt aangegeven dat een reële toedracht correspondeert met de definitie van de verwijzingscategorie ${ }^{505}$. Kwalificatie aan de hand van de verwijzingscategorie 'huwelijk' is de beslissing dat een feitencomplex voldoet aan de definitie van de verwijzingscategorie. Aan de kwalificatie gaat vooraf dat de definitie van de verwijzingscategorie wordt geconfronteerd met de eigenschappen van het feitencomplex ${ }^{906}$. Er dient een kwalificerend begrip te worden gezocht ${ }^{900}$ dat de definitie van de verwijzingscategorie preciseert. Het kwalificatieprobleem is het probleem van het definierren van conflictenrechtelijke begrippen ${ }^{908}$. De moeilijkheid is dat de definitie wan de nationale verwijzingscategorie niet precies is ${ }^{909}$.

902. Kegel, 242, geeft het voorbeeld van materièle regels omtrent "Pflichteil' en 'Noterbe' die onder de Duitse verwijzingstegel voor het erfrecht vallen en niet onder de verwijzingsregel voor het zakenrecht. Cf. Stone, 387: het kwalificatieprobleem doet zich uitsluitend voor als materiêle regels verschillende oplossingen voor een casus bieden. Overigens is her kwalificatieprobleem te onderscheiden van thet kwallificatieconflict. Een kwalificatieconflict doet zich voor wanneer het feitencomplex door het vreemde rechtsstelsel afwijkend gekwalificeerd zou worden met als bijzonder gevolg dat het buitenlandse rechtsstelsel een verwijzingsregel van toepassing zou achten met een resultaat dat strijdig is met de verwijzing die het gevolg zou zijn wan de kwalificatie volgens het eigen rechtsstelsel: Audit 1991, 170171; Batiffol/Lagarde, 476, 489; Mayer, 115. Indien niet beslist kan worden of de eigen dan wel de buitenlandse kwalificatie met de daa ruit voortwoeiende verwijzing prevaleert, wordt het kwalificatieprobleem verscherpt tot een $k$ wallificatieconflict: rechtsstelsel $A$ kwalificeert een verloving alan de hand wan het contractenrecht en verwijst daarom naar rechtsstelsel B, terwijl rechtsstelsel $B$ dezelfde verlowing aan de hand van het familierecht kwalificeert en daarom mar rechtsstelsel $A$ of $C$ verwijst: cf. Levontin, 141, 146; of. North/Fawcett, 45. Dit kwalificatieconflict is eigenlijk een verwijzingsprobleen omdat de afwijketade verwijzing het resultaat is wan een strijdige kwalificatie: of. Niederer, 49 ; cf. Rigaux 1989, 127. Het kwalificaticconflict voegt een verwijzingsprobleem toe aan het kwalificatieprobleem: Knoepfler/Schweizer, 137. Dit verwijzingsprobleen blifft herna buitem beschouwing. In het algemeen zijn uiterenlopende kwalificaties te verzoenen: of. Audit 1993, 59.

903. Zie BGH 28-1-1987. Neue Juristische Wochenschrift 1987, 2161-2164: ongeacht de kwalificatie van de "mahr" moet naar Duitse nateriële tegels verwezen worden zodat en definitieve beslissing omtrent de $\mathrm{kwalificatie}$ overbodig is. Hienuit blijkt dat het $\mathrm{kwalificatieprobleem} \mathrm{toch} \mathrm{aan} \mathrm{de} \mathrm{orde} \mathrm{gesteld} \mathrm{moet}$ worden.

904. Cf. Ancel, $233-234$.

905. Cf. Eisenmatno, 28, 34.

906. Cf. Batiffol/Lagarde, 480 .

90\%. Rigaux 1987, 228. Bij de aanduiding "begripskwalificatie' dient men zich ervan bewust te zijn dat het begrip warnee gekwalificeerd moet worden, in eerste instantie niet beschikbaar is.

908. Niederer; $42,49$.

909. Of dat dete definitie zells ontbreekt. Cf. Gusy, 218: ten rechtsbegrip bevat veelal geen definitie. 
Het zoeken van een kwalificerend begrip is de kern ${ }^{910}$ van het kwalificatieprobleem in het IPR. Om te kunnen kwalificeren dient de vaagheid van de verwijzingscategorie ${ }^{911}$ te worden verminderd. De samenhang tussen begripskwalificatie en vaagheid van begrippen is echter niet expliciet verwoord in de literatuur van het IPR. Vandaar de volgende opmerkingen omtrent vaagheid van begrippen in het geval van vaagheid kan niet worden beslist tot toepassing van een begrip op een object ${ }^{912}$. Dit object is een 'neutrale kandidaat' omdat onduidelijk is of het object tot de extensie ${ }^{913}$ van het vage begrip behoort ${ }^{914}$. De intensie ${ }^{915}$ van een vaag begrip is niet volledig; deze intensie moet worden omgezet in een preciserende definitie die de vaagheid vermindert ${ }^{916}$. De onvolledige intensie moet worden aangevuld met additionele kenmerken ${ }^{917}$. Deze opmerkingen impliceren het volgende voor het kwalificatieprobleem in het IPR: zolang de verwijzingscategorie een vaag begrip is met een onvolledige intensie kan het feitencomplex niet gekwalificeerd worden door toepassing van een verwijzingscategorie. Om de vage contouren van de verwijzingseategorie af te bakenen moet eerst de intensie van de verwijzingscategorie worden aangevuld met additionele kenmerken. In het stadium dat nog niet vaststaat naar welk rechtsstelsel moet worden verwezen, moet de definitie van de verwijzingscategorie worden gepreciseerd. Met een preciserende definitie wordt de vaagheid van de verwijzingscategorie verminderd en wordt het toepassingsbereik van de verwijzingsregel exacter bepaald.

Een geschikt kwalificerend begrip is onontbeerlijk voor de oplossing van het kwalificatieprobleem. De kwalificatie aan de hand van een verwijzingscategorie gaat noodzakelijkerwijs vooraf aan de toepassing van de gekozen verwijzingsregel. Begripskwalificatie staat aan het begin van het traject dat eindigt met de beslechting van het geschil. Eerst dient de kwalificatievraag beantwoord te worden; van die beslissing hangt af welke verwijzingsregel gehanteerd wordt om de toepasselijke wet aan te wijzen ${ }^{918}$. Het kwalificatieprobleem is prealabel aan de verwijzing ${ }^{919}$. Het probleem van het kwallificeren

910. Overigens is niet zozeer sprake van bet kwalificatieprobleem als zodanig, nuar weeleer van min of meer samenhangende wragen die zich richten op het begripsmatig te werk gaan: Salomon, 31,135 . Kegel, 259: er zijn massa's kwalificatievragen zonder algemene oplossing.

911. Rigaux 1987, 319.

912. Kuhlen 1976,53 noot 1; Kuhien 1977, 81-82; cf. Pawlowski, 168.

913. Zie II.\& 1.

914. Franken, 73; Herberger/Simon, 288-289; Loth 1991, 96. Cf. Pawlowski, 17l: vage begrippen zijn niet wetenschappelijk; cf. Sartori, 28,43 .

915. Zie 11.81 .

916. Franken, 72, 77, 79; cf. Herberger/Simon, 316-317.

917. Kuhlen 1977, 146; cf. Sartori, 26, 42, 46.

918. Kosters/Dubbink, 242; cf. Keller/Sielur, 438-439.

919. Batiffol/Lagarde, 479; cf. Ancel. 263; cf. Schlosshauer, 27 noot 160. 
van een feitencomplex gaat vooraf aan de verwijzing naar het toepasselijke recht ${ }^{\$ 20}$. Van de kwalificatie aan de hand van een verwijzingscategorie is afhankelijk door welke verwijzingsregel het toepasselijke rechtsstelsel wordt aangewezen. De toepassing van materiële regels is pas mogelijk na kwalificatie aan de hand wan een verwijzingscategorie. Deze kwalificatie vereist op haar beurt dat de definitie van de verwijzingscategorie wordt gepreciseerd aan de hand van nationale of buitenlandse rechtsbegrippen.

De kwalificatie van een feitencomplex is gesitueerd in een internationaal kader. Het kwalificatieprobleem in het IPR behelst de noodzaak om de definitie van de verwijzingscategorie te preciseren zonder buitenlandse rechtsbegrippen bij voorbaat uit te sluiten. Het kwalificatieprobleem in het IPR zal hierna worden afgebakend ten opzichte van achtereenvolgens:

a. de vaagheid van een begrip van nationalle regelgeving;

b. de concretisering van een aanknopingsfactor;

c. de zogeheten 'secundaire kwalificatie".

Ad a: het verschil tussen de vaagheid van een verwijzingscategorie en de vaagheid van nationale begrippen zal met het volgende voorbeeld worden toegelicht: de Hoge Raad ${ }^{921}$ heeft vastgesteld dat de zeilplank een vaartuig is in de zin van het Vaarreglement. De kwalificatie van een zeilplank als vaartuig berust op een opsomming van onderdelen, hoedanigheden, bestemming en gebruiksmogelijkheden van dlat voorwerp. Ondanks de afwijkende constructie acht de Hoge Raad de overeenkomst met andere zeilschepen zodanig doorslaggevend dat de zeilplank voldoet aan de definitie van het begrip 'vaartuig' in het Vaarreglement. Het onmiddellijke gevolg van de kwalificatie van een zeilplank als een vaartuig is dat het nationale Vaarreglement wordt toegepast op zeilplanken ${ }^{922}$. Het Vaarreglement verwijst niet naar materiële regels maar bevat zelf de toepasselijke norm. Hierin ligt het eerste verschil met de begripskwalificatie in het IPR: de begripskwalificatie leidt tot toepassing van een verwijzingsregel. Bovendien wordt de vaagheid van het begrip 'vaartuig' op andere wijze verminderd dan de vaagheid van een verwijzingscategorie: in het eerste geval is rechtsvergelijking overbodig. Door de aanvulling van de intensie van het begrip 'vaartuig' is de zeilplank niet langer een neutrale kandidaat ${ }^{2 / 3}$. Het verschil tussen kwalificatie binnen één rechtsstelsel en rechtsvergelijkende begripskwalificatie is de complicatie dat in het laatste geval de

920. Cf. Rigaux 1956, 263; cf. Rigaux 1987, 324.

921. HR 4-3-1980, Nederlandse Jurispridentie 1980 no. 350, met noot T. W. van Veen; cf. Schuyt 1981. 14.

922. Franken, 88.

923. Franken, 73, 87. 
buitenlandse wet soms anders kwalificeert dat de onze, hetgeen de vraag doet rijzen of wij overeenkomstig die buitenlandse dan wel overeenkomstig onze eigen wet moeten kwalificeren ${ }^{924}$. De selectie van juridische eigenschappen van het te kwalificeren voorwerp is in het IPR afhankelijk van verschillende begrippenstelsels ${ }^{925}$. Het kwalificerende begrip moet door middel van rechtsvergelijking voorzien in de selectie van gemeenschappelijke eigenschappen.

Ad b: het kwalificatieprobleem in het IPR doet zich uitsluitend voor bij de verwijzingscategorie. Andere delen van de verwijzingsregel zoals de aanknopingsfactor leiden niet tot een kwalificatiewraag. De aanknopingsfactor wordt niet gekwalificeerd maar uitgelegd ${ }^{926}$. Zo behoort de bepaling van het woonplaatsbegrip in een aanknopingsfactor niet tot het kwalificatieprobleem ${ }^{927}$. De uitleg van de aanknopingsfactor is pas aan de orde nadat vaststaat welke verwijzingsregel toegepast moet worden. Pas nadat tot toepassing van de verwijzingsregel is geconcludeerd, wordt de aanknopingsfactor na interpretatie geconcretiseerd voor een feitelijke situatie ${ }^{928}$, hetgeen iets anders is dan kwalificeren ${ }^{929}$. De uitleg van de aanknopingsfactor kan strikt genomen uitsluitend aan de hand van het eigen recht geschieden maar een internationaal uniforme uitleg is wenselijk. De aanknopingsfactor is een norm van het eigen recht zodat het begrip van de aanknopingsfactor kan worden uitgelegd aan de hand van het nationale begrippenstelsel ${ }^{930}$. Het woonplaatsbegrip wordt uitgelegd ${ }^{931}$ aan de hand wan het rechtsstelsel met de verwijzingsregel die wordt toegepast ${ }^{932}$. De woonplaats is een begrip van het eigen IPR; dit begrip dient zo universeel mogelijk gedefinieerd te worden om te beantwoorden aan eenheidseisen ${ }^{933}$. Als de woonplaats een autonoom conflictenrechtelijk begrip is, wordt er niet uitsluitend gerefereerd aan het internrechtelijke begrip woon-

924. Van Brakel, 64 .

925. Cf. Van Ginsbergen 1968, 353, 356; ef, Weber, 216, 231. Cf. Brouwer, 41: welke eigenschappen van verschijnselen men waaneemt, is in sterke mate afhankelijk van het geheel van samenhangende begrippen warmee die verschijnselen worden benaderd.

926. Firsching/von Hoffmann, 198.

927. Knoeptler/Schweizer, 136-137.

928. Dörner, 349: "nationaliteit' is een uitzondering in dit opzichut. In een ander opzicht is 'nationaliteit" een uitzondering ondat 'mationaliteit' in beginsel wordt bepaald door de stat waarvan men beween de nationaliteit te bezitten: of. Dörner, 350, cf. Strikwerda, 100, 108; cf. Sehurig, 227. Qua feitelijkhe id en qua autonomie neemt 'nationaliteit' als aanknopingsfactor een uitzonderingspositie in,

929. Lemaire, 333; Neuhaus, 114.

930. Cf. Strikwerda, 63.

931. Keller/Siehr, 436.

932. Raape/Sturm, 106-107.

933. Cf. Rigaux 1987, 247-248. 
plaats dat van land tot land nogal sterk verschilt en wordt er in beginsel zelfstandig bepaald wat onder woonplaats verstaan dient te worden ${ }^{934}$.

Ad c. van het kwalificatieprobleem in het IPR is niet langer sprake wanneer de gekozen verwijzingsregel gevolg heeft gekregen in de toepassing van een of ander rechtsstelsel. Daarom behoort de kwalificatie na het vinden van een verwijzingsregel, de zogeheten 'secundaire kwalificatie', niet tot het kwalificatieprobleem in enge zin. Met de secundaire kwalificatie wordt de $\mathrm{kwalificatie}$ aangeduid die nodig blijkt nadat men heeft uitgemaakt welke rechtsorde ingevolge de in aanmerking komende regel van IPR moet worden toegepast ${ }^{\text {955 }}$. De secundaire kwalificatie is een kwestie van toepassing van het buitenlandse materièle recht ${ }^{936}$. Het begrippenstelsel van de toepasselijke wet is beslissend voor de uitleg van de buitenlandse bepalingen die van toepassing zijn ${ }^{937}$. Bovendien is het buitenlandse begrippenstelsel bepalend voor de omvang waarin het aangewezen recht moet worden toegepast als het vreemde rechtsstelsel een afwijkende indeling in rechtsgebieden kent ${ }^{938}$. Is bijvoorbeeld ${ }^{939}$ een in Duitsland verbroken verloving naar Frans recht als een onrechtmatige daad gekwalificeerd dan respecteert de Franse rechter dat het toepasselijke Duitse recht de aanspraken uit het verbreken van de verloving bij het familierecht indeelt ${ }^{240}$. De Duitse secundaire kwalificatie wordt geèerbiedigd ook al is die afwijkend van de Franse kwalificatie. Het vreemde materiële recht moet worden toegepast zoals de buitenlandse rechter dat zou doen ${ }^{941}$. Het buitenlandse recht bepaalt de omvang waarin dat toegepast moet worden. De toepassing van de verwijzingsregel moet volledig worden gescheiden van de toepassing van de materiele regel van het rechtsstelsel waarnaar is verwezen ${ }^{942}$. Als de toepasselijke verwij-

934. Cf. Strikwerda 108 .

93. Van Pragg, 531.

936. Lemaine, 342; cf. Kosters/Dubbink, 249. Anders dan bij het kwalificatieconflict is hier de buitenlandse verwijzingsregel niet atan de orde: of. Levontin, 146.

937. Van Btakel, 70; ef. Schwander, 142.

938. Mayer, 122, cf. Strikwerda, $63-64$.

939. Striewe, 288-289; wolgens frans recht kan een verbroken verloving ten onrechtmatige daad opleweren. Een ander voorbeeld: indien een Zwitserse rechter Frans recht wan toepassing acht op een verbroken verlowing wordt de omvang van de toepasselijke Franse regels niet beperkt tot het familierecht waarbij het $Z$ witserse recht deze kwestie indeelt: Knoepfllen/Schweizer, 140, Vischer, 17.

940. Knoephler/Schweizer, 139.

941. Lemaire, 354: North/Fitwcett, 49; Robertson, 32, 130-132. Anders Strikwerda, 64: de secundaire kwalificatie volgt de primaire $k$ walificatie bij het vaststellen van de omvang waarin het aangewezen rechtsstelsel moet worden toegepast. Cf. Schwimann, 17: gekanaliseerde verwijzing.

942. Niederer, 99. 
zingsregel nog niet is gevonden, is de buitenlandse begripsindeling niet bepalend voor de omvang van de verwijzing ${ }^{943}$.

Het zoeken van een kwalificerend begrip is de kern van het kwalificatieprobleem. Het kwalificerend begrip wordt toegepast op het voorwerp van de begripskwalificatie. Verschillende opyattingen omtrent het voorwerp van begripskwalificatie komen ter sprake in $\$ 2$. In $\& 3$ wordt ingegaan op de grondslag van de begripskwalificatie de maatstaf voor de precisering van de definitie van de verwijzingscategorie.

\section{§ 2. Het voorwerp van de begripskwalificatie}

\section{A. HET PREJURIDISCHE VOORWERP}

In het voorafgaande is het voorwerp van begripskwalificatie aangeduid als een feitencomplex, een toedracht of een feitelijke situatie. Daarbij moet sprake zijn van een samenloop van rechtsstelsels want anders ontbreekt het object van het IPR ${ }^{944}$. Dit is echter een te eenvoudige voorstelling van datgene waarop de begripskwalificatie volgens de literatuur betrekking zou kunnen hebben. Wat het voorwerp van kwalificatie is of moet zijn, is omstreden ${ }^{945}$. Er zijn verschillende perspectieven mogelijk ten aanzien van het voorwerp van de begripskwalificatie ${ }^{946}$. De aard van het voorwerp van de begripskwalificatie is van belang voor het vaststellen van de definitie van de verwijzingscategorie omdat het te beoordelen geval aanleiding is voor het zoeken van een definitie ${ }^{947}$. Er wordt geen kwalificerend begrip gezocht als de verwijzingscategorie niet vaag wordt geacht ten opzichte van het voorwerp van begripskwalificatie, maar wel als dit voorwerp een neutrale kandidaat is ${ }^{948}$. Daarom wordt het voorwerp van begripskwalificatie hierna besproken. Het is van belang of het voorwerp van begripskwallificatie al dan niet rechtsnormen bevat: in het eerste geval vindt de precisering van bedoelde definitie plaats voor rechtsnormen ook al hebben deze rechtsnormen geen gelding ${ }^{949}$ in de prealabele fase waarin het kwalificatieprobleem optreedt. In het tweede geval kunnen rechtsnormen geen aanleiding geven tot precisering van de definitie van de verwijzingscategorie. Daarom zal het voorwerp van begripskwalificatie hierna worden

943. Firsching/von Hoffmann, 199, 202; Raape/Sturm, 276.

944. Zie VI.\$1.A.

945. Weber, 215. Volgens Von Bar, 518, is de kwestie van weinig belang.

946. Cf. Niederer, 94.

947. Cf. Gusy. 218.

948. Zie VI.\$1.B.

949. Cf. Gusy, 220. 
onderscheiden in een prejuridisch voorwerp en een juridisch voorwerp. Het prejuridisch voorwerp bevat geen rechtsnormen en is een feitencomplex, een toedracht of een feitelijke situatie. Het juridische voorwerp komt aan de orde nadat het prejuridische voorwerp is besproken. Het juridische voorwerp van begripskwalificatie zal worden onderscheiden in "rechtsvragen" en "rechtsregels"; daarover gaan \& 2.B en \$2.C. Eerst komt aan de orde wat is te verstaan onder de opvatting dat het voorwerp van begripskwalificatie een prejuridisch object is.

Rabel is de grote voorstander van de opvatting dat het voorwerp van begripskwallificatie een prejuridisch voorwerp is. Volgens Rabel ${ }^{950}$ is er in het stadium dat de materiële rechtsregels nog onbekend zijn, slechts een feitelijke of 'sociale' situatie; er kan dan geen sprake zijn van een rechtsverhouding. Hij huldigt het standpunt dat verwijzingsregels betrekking hebben op de feiten van het leven, op feitelijke gebeurtenissen zoals het overlijden van een persoon die geen testament nalaat. Hij bestrijdt dat het voorwerp van begripskwalificatie abstract zou moeten zijn, hetgeen het gevolg zou zijn van de hantering van een juridische definitie. Naar zijn mening is de opvatting van het prejuridische voorwerp van kardinaal belang: er zou niet langer beweerd kunnen worden dat verwijzingsregels noodzakelijkerwijs afhankelijk zijn van een of ander rechtsstelsel. Volgens Rabel heeft de verwijzingscategorie geen betrekking op materiële rechtsverhoudingen, maar op feiltelijke 'Lebensverhältnisse' die nog juridisch beoordeeld moeten worden ${ }^{551}$. Deze 'Lebensverhältnisse' zijn een centraal begrip bij Rabel ${ }^{952}$. Volgens Rabel is de ideale $_{;}$zij het utopische verwijzingsregel gericht op zuivere feiten als op een "Urstoff" ${ }^{953}$. Deze 'Urstoff' is volgens Rabel universeel omdat overal uniforme levensvragen terugkeren ${ }^{954}$. Verondersteld wordt dat de 'Lebensverhältnisse' en de daaruit voortkomende problemen in de moderne wereld veel meer overeenkomst vertonen dan de juridische constructies om die problemen op te lossen ${ }^{955}$. Het juridische voorwerp is slechts een middel om bij het substraat van de "Lebensverhältnisse" te komen: rechtsverhoudingen en juridisch beoordeelde feiten zijn niet meer dan een

950. Rabul 1958, 51 52 .

951. Rabel 1931, 245; Rigaux 1956, 146, Drobnig 1977, 32, herkent zijn opvatting in die van Rabel. Volgens Kötz (mondeling op 12-1-1996) zijn de "Lebenswerhältnisse' identiek aan de sociale problemen die in de functionele beginvrage (zie $11 . \$ 3 . C$ ) omschreven worden.

952. Weber, 116.

953. Rabel $1931,244$.

954. Rabel 1931, 258; cf. Weber, 241-242.

955. Kropholler 1994, 110; Neuhaus, 129; cf. Rigaux 1956, 149. Coing, 15 geeft aan op welke 'achterliggende" identificatiecriteria deze veronderstelde overeenkonist op haar beurt gefundeerd kan zijn waar het on het Europese continent gaat; of. Rheinstein, 13, 26. Het reelutsstelsel in kwestie moet voldoende ontwikkeld zijn: Batiffol/Lagande, 488. 
middel om het prejuridische voorwerp te bereiken ${ }^{956}$. Volgens Rabel moet zoveel mogelijk worden voorkomen dat het voorwerp van begripskwalificatie bij voorbaat wordt beïnvloed door een of ander rechtsstelsel ${ }^{957}$. Niettemin moeten vreemde materiële regels in de overwegingen betrokken worden indien de "Lebensverhältnisse" optreden in een juridisch beinvloede vorm ${ }^{958}$.

Volgens Rigaux ${ }^{959}$ is de opvatting van Rabel onjuist omdat het voorwerp van begripskwalificatie slechts met rechtsbegrippen beschreven kan worden. 'Lebensverliältnisse' hebben geen betekenis voor de jurist ${ }^{960}$. Het voorwerp van begripskwalificatie is volgens Rigaux ${ }^{961}$ van juridische aard en afhankelijk van een onbepaalbare diversiteit van systemen van materieel recht. Het voorwerp van begripskwalificatie is geen zuivere situatie van het leven ${ }^{962}$. De beschrijving van de feitelijke situatie impliceert volgens hem het gebruik van begrippen van materieel recht die zijn ontleend aan rechtsstelsels die de situatie als het ware op voorhand hebben gevormd ${ }^{963}$. Deze kritiek wordt gedeeld door andere auteurs. Zo wordt tegengeworpen dat 'Lebensverhältnisse' oneindig veel vragen kunnen oproepen zodat het onderzoek geen richting wordt gewezen ${ }^{364}$. Een feitencomplex dat in het geheel niet aan rechtsregels is gerelateerd, is niet vatbaar voor subsumptie onder de verwijzingscategorie ${ }^{965}$. De 'Lebensverhältnisse' moeten een juridische inhoud bezitten om in aanmerking te komen als voorwerp van begripskwalificatie ${ }^{966}$. Het juridische voorwerp van begripskwalificatie is volgens deze kritiek hanteerbaar, het prejuridische niet. Het prejuridische voorwerp van begripskwalificatie geeft altijd aanleiding tot precisering van de verwijzingscategorie maar biedt geen enkele hulp bij het vinden van een kwalificerend begrip.

956. Rabel 1931,244.

957. Rabel 1931, 245.

958. Rabel $1931,262$.

959. Rigaux 1984, 243-244; Rigaux 1987, 228. Zo ook Esser, 299; er moet niet worden beslist ower zuiver voorjuridische feiten zonder juridische karakterisering; het gat om een selectie uit de 'Urstoff'.

960. Rigaux 1989, 88; cf. Robertson, 60 61: het voorwerp van begripskwalificatie is niet juridisch ondat de juridische aard ervan nog vastgesteld moet worden door middel wan $k$ wallificatie. Dit neemt niet weg dat een voorlopige bepaling van de juridische aard van het woorwerp van begripskwalificatie mogelijk is zonder rechtsgevolgen te specificeren aan de hand wan één reclitsstelsel.

961. Rigaux 1984, 244.

962. Rigaux 1956, 151 .

963. Rigaux 1987, 231 .

964. Weber, 230.

965. Dörner, 349. Dörner 350 kiest dan ook voor de rechtsvragg als voorwerp van begripskwalificatie.

966. Makarov, 156 noot 23. 


\section{B. DE RECHTSVRAAG ALS VOORWERP}

Volgens de kritiek op Rabel is het prejuridische voorwerp van begripskwalificatie onhanteerbaar. Dat leidt tot de vraag of het juridische voorwerp hanteerbaar is. Daarbij staat voorop dat de tegenstanders van Rabel toestaan dat materiële regels elementen van het voorwerp van begripskwalificatie zijn voordat de verwijzingsregel materiële regels toepasselijk verklaart. Zo zouden rechtsbetrekkingen het object van kwalificatie kunnen zijn omdat zij niet precies behoeven vast te staan zodat men niet kan beweren dat zij hun rechtskarakter eerst verkrijgen door een rechtsorde die nog moet worden aangewezen door de toe te passen verwijzingsregel ${ }^{967}$. Bovendien staat veelal tevoren vast dat het niet om een zuiver feitelijke verhouding gaat maar om een feitelijke betrekking met juridische inhoud. Daaraan doet geen afbreuk dat bij de begripskwalificatie nog onbekend is welk materiële recht op de feitelijke verhouding wordt toegepast ${ }^{968}$. Met de introductie van materiële regels in het voorwerp van begripskwalificatie wordt echter afstand genomen van een volledige scheiding tussen conflictregells enerzijds en materiële regels anderzijds ${ }^{969}$.

De rechtsvraag is een tussenvariant die gedeeltelijk juridisch is. Dit voorwerp van begripskwalificatie bevat materiële regels maar is niet uitsluitend vanuit een juridisch gezichtspunt bepaald. Dat blijkt uit de volgende overwegingen. De rechtsvraag heeft een centrale plaats in het kwalificatieproces want de rechtsvraag ligt op het snijpunt tussen feiten en recht ${ }^{970}$. De rechtsvraag is de verbindingsschakel tussen de zuiver feitelijke "Lebenssachverhalt" enerzijds en de abstracte juridische verwijzingscategorie anderzijds, met dien verstande dat de rechtsvraag wordt gespecificeerd door de verwijzingscategorie ${ }^{971}$. Hieruit blijkt dat de rechtsvraag heterogeen is omdat dit voorwerp van begripskwalificatie zowel feitelijke als juridische elementen bevat. Daarbij is de rechtsvraag voldoende concreet om werkbaar te zijn terwijl de rechtsvraag voldoende openstaat voor

967. Kosters/Dubbink, 243. Het juridische voorwerp van begripskwallifictie wordt nog op andere wijzen aangeduid. Kosters/Dubbink, 243: rechtsfiguren; Weber, 203: onder meer rechtsinstellingen; Gamillscheg, 84: rechtsvrag of materiẻle rechtsregels; Sauweplanne 1989, 83-85: rechtsfeiten of rechtsinstellingen. Hier volstaat een onderscheid van het juridische voorwerp in de rechtswraag enerzijds en materiale regels anderzijds. Andere varianten blijven buiten beschouwing.

968. Gamillscheg, 84 ,

969. Cf. Niederer, 95, 99. De scheiding ussen conflictregels en materiële regells wordt niet in acht genomen indien nationale verwijzingscategorie wordt vergeleken met een buitenlandse rechtsfiguur die onbekend is in de lex fori: cfi. Meyer, 130-131. De vergelijking van collisieregels en materiële regels is nodig voor de keuze wan een collisieregel voor de verloving: Von Bar, 509.

970. Weber, 228.

971. Heyn, 20-21. 
het vreemde rechtsstelsel ${ }^{972}$. Het is mogelijk dat juridische elementen in de rechtsvraag nog niet vaststaan, bijvoorbeeld of goederen roerend of onroerend zijnn ${ }^{973}$. Deze juridische elementen zijn neutrale kandidaten ${ }^{974}$.

Er zijn bezwaren geformuleerd tegen de rechtswraag als voorwerp van begripskwalificatie. Een bezwaar is dat de rechtsvraag geen zelfstandig voorwerp van begripskwalificatie is omdat de rechtsvraag met behulp van materiële regels wordt gefornuleerd: de rechtsvraag is het probleem dat met de rechtsregel moet worden opgelost ${ }^{975}$. In dit opzicht is de rechtsvraag afhankelijk van materiële regels ${ }^{976}$. Daarbij kan het misverstand ontstaan dat het niet gaat om in aanmerking komende regels van verschillende rechtsstelsels, maar om uiteindelijk gevonden rechtsregels ${ }^{\text {s7 }}$ van het als toepasselijk aangewezen rechtsstelsel. De rechtsvraag doet zich niet alleen voor binnen het kwalificatieprobleem maar ook nadat een rechtsstelsel toepasselijk is verklaard: dan moet de rechtsvraag met behulp van materiële regels worden beantwoord ${ }^{978}$. Het bezwaar tegen de rechtsvraag is bovendien dat de rechtsvraag manipulatie van de kwalificatie ${ }^{979}$ niet voorkomt, omdat niet duidelijk wordt onderscheiden tussen het voorwerp van begripskwalificatie en de uiteindelijk gevonden regels. Dan vindt de kwalificatie plaats met het oog op het gewenste resultaat ${ }^{980}$. De rechtsvraag kan leiden tot een definitieve keuze van materiële regels ofschoon nog niet is verwezen naar een rechtsstelsel waarvan de materiële regels toegepast moeten worden.

Een ander bezwaar is dat de rechtsvraag kan worden opgevat als de rechtsvraag die wordt voorgelegd aan de rechter ${ }^{981}$. Dan is wederom onduidelijk welke materiële regels daarin figureren. Het is minder aannemelijk dat dit uitsluitend de materiële regels zijn waarop een procespartij haar eis baseert ${ }^{982}$. Een aanspraak kan gebaseerd zijn op rechtsregels die in de betrokken rechtsstelsels ontbreken ${ }^{983}$. De presentatie van de

972. Weber, 230-231.

973. Neuhaus, 120; Kropholler 1994, 102.

974. Zie VI.\$1.B.

975. Hoppe, 13 .

976. Cf. Gundmann, 11,28 noot 72 .

977. Cf. Heyn, 18: cf. Hoppe, 13-14.

978. Weber, 223: de verwijzingsregel beantwoordt de rechtsw rag nog niet.

979. Sauveplanne 1982, 38; cf. Audit 1993,60-62; cf. Steindorff, 113; cf. Stome, 387.

980. Cf. Mayer, 120: kwalificatie moet problemen wan 'aanpassing' zoveel mogelijk voorkomen. Het IPRleerstuk van de "aanpassing" blijf hier buiten beschouwing.

981. Dit is het standpunt van Mayer, 112-113.

982. Cf. Batiffol/Lagarde, 477. De eis van een procespartij kan niet zonder meer beslissend zijn voor de kwallificatie.

983. Cf. Gamillscheg, 84 . 
rechtswraag kan niet beslissend zijn voor de inhoud van dit voorwerp van begripskwalificatie want de juridische elementen in de rechtswraag zijn niet beperkt tot de materiële regels die in het woordeel van een procespartij zijn. De procespartij die een verbroken verloving kwalificeerde als een onrechtmatige daad met het oog op schadevergoeding naar Belgisch recht, had geen succes bij de rechtbank ${ }^{984}$. Het is overigens niet denkbeeldig dat een procespartij de voorkeur geeft aan toepassing van het nationale recht. Dit is in strijd met de vard van de meerzijdige conflictregel waarbij geen onderscheid wordt gemaakt tussen de toepassing van buitenlands en nationaal recht ${ }^{985}$. De rechtsvraag is bovendien niet specifiek voor de meerzijdige conflictregel omdat elk rechtsprobleem in het IPR een rechtsvraag oplevert. Daarom wordt hier de voorkeur gegeven aan rechtsregels als voorwerp, mede ondat het prejuridische voorwerp omstreden is. Dit standpunt wordt in $\$ 2 . \mathrm{C}$ toegelicht.

\section{RECHTSREGELS ALS VOORWERP}

Het standpunt dat uitsluitend rechtsregels het juridisch voorwerp zijn van begripskwalificatie verdient de voorkeur mits het slechts gaat om in aanmerking komende rechtsregels: in het onderhavige stadium staat niet vast naar welk rechtsstelsel moet worden verwezen ${ }^{986}$. De kritische waardering van de oplossing van een of ander rechtsstelsel is hier niet aan de orde. Onder deze voorwaarde zijn materiële regels het voorwerp dat past bij de meerzijdige conflictregel ${ }^{987}$. De meerzijdige conflictregel omvat zowel nationale als buitenlandse rechtsregels; de aanknopingsfactor kan naar de buitenlandse regels binnen deze extensie leiden ${ }^{988}$. Ondanks nationale verschillen sluit de meerzijdige conflictregel toepassing van buitenlands recht niet uit ${ }^{989}$. Deze conflictregel is onpartijdig ${ }^{990}$ en verwijst naar een soort ${ }^{99 !}$ van rechtsregels, niet naar die van een of ander rechtsstelsel. De verwijzingscategorie is een soortbegrip ${ }^{992}$. Het onderwerp van de verwijzingscategorie van een verwijzingsregel bestaat uit 'klassifizierte Rechtssătze' ${ }^{993}$. Deze 'klassifizierte Rechtssätze' zijn abstract weergegeven in de verwijzingsregel. De verwijzingscategorie is beperkt tot een groep van rechtsnormen, bijvoor-

984. Rb Rotterdam 27-7-1932, Nederlandse Jurispudentie 1933, p. 311-312; Cohen Henriquez 1980, 47.

985. Zie VI.\& 1.A.

986. Cr. Heym, 18, 72.

987. Cf Collier, 16/17.

988. Zie VI: 1 1.A.

989. Kegel, 54-55, 228-229.

990. Kegel, 54; cf. Rabel 1958, 62; cf. Verheul, 4, 66.

991. Kegel, 53, 240.

992. Heyn, 30.

993. Fikentscher, 778-780; Wengler, 373. 
beeld de adoptieregels. Deze abstract weergegeven rechtsregels hebben niet rechtstreeks ${ }^{994}$ betrekking op een feitelijk substraat: onder die groep van rechtsregels moeten de in aanmerking komende 'wirkliche Rechtssätze' gesubsumeerd worden ${ }^{995}$. Het feitencomplex wordt op zijn beurt gesubsumeerd onder de 'wirkliche Rechtssätze' of materiële regels die het voorwerp zijn van de begripskwalificatie ${ }^{9 \%}$. Het feitencomplex is zelf geen voorwerp van de begripskwalificatie.

Volgens de hier verdedigde opvatting is begripskwalificatie het vormen van een soortbegrip ${ }^{997}$ voor 'klassifizierte Rechtssätze" op een zodanige wijze dat 'wirkliche Rechtssätze' tot de extensie van dat soortbegrip behoren. De in aanmerking komende materiële regels moeten worden geïdentificeerd voor het onderwerp van de verwijzingscategorie ${ }^{998}$. Er dient te worden onderzocht: primo wat de aard is van de materiële bepalingen die de conflictregel aanwijst; secundo wat de aard is van de materiële regels waarvan beweerd wordt dat zij toepasselijk zouden zijn; tertio of het tweede rijmt met het eerste ${ }^{939}$. Indien in het stadium van begripskwalificatie onvoldoende vaststaat om welke 'wirkliche Rechtssätze' het precies gaat zodat een subsumptie onder de verwijzingscategorie onmogelijk is, is er sprake van neutrale kandidaten ${ }^{1000}$. Deze neutrale kandidaten zijn beperkt tot materiële regels van verschillende rechtsstelsels met uitsluiting van een prejuridisch voorwerp van begripskwalificatie en van juridische elementen in een rechtsvraag. De intensie van de verwijzingscategorie moet zonodig worden aangevuld met additionele kenmerken om een geschikt kwalificerend begrip te vinden ${ }^{1001}$. Kenmerken van buitenlandse rechtsbegrippen kunnen behulpzaam zijn bij de precisering van de definitie van de verwijzingscategorie voor materiële regels. De grondslag van begripskwalificatie bepaalt in hoeverre buitenlandse begrippenstelsels betrokken mogen worden bij deze precisering. Over deze grondslag gaat $\$ 3$.

994. Cf. Meyer, 130 .

995. Het concrete dat wordt gesubsumeerd èn het abstracte bestaan hier uit rechtstegels: of. Rapa/Sturm, $276,279,280$. Cf. Heyth, 30 en Rigaw 1956,456 : in het geval wan kwallificatie wordt een rechtsregel gesubsumeerd. Neuhaus, 114 en Kropholler 1994, 98, menen echter dat het spraakgebruik niet toestaat om te spreken van een subsumptie van regels omdat regels slechts 'Obersatx' zoudien kunnen zijn.

996. Fikentscher, 779-780.

997. Zie $11 . \$ 1$.

998. Dörner, 347.

999. Lemaire, 336; nagenoeg gelijkluidend: Raape/Sturm, 276. De derde vraag is volgens Raape/Sturm, 279 , het hoofdthema, het eigenlijke slagveld.

1000. Zie VI. 1.B.

1001. Zie VI.8 1.B. 


\section{§3. De grondslag van begripskwalificatie}

\section{A. LEX FORI ALS UTTGANGSPUNT}

De grondslag van begripskwalificatie is de maatstaf ${ }^{1002}$ voor de precisering van de definitie van de verwijzingscategorie. Omdat bij de begripskwalificatie de reikwijdte van de verwijzingscategorie wordt onderzocht, wordt deze maatstaf nader bepaald ten opzichte van het rechtsstelsel met de verwijzingscategorie: de lex fori. Als de verwijzingscategorie slechts de eigen materiêle regels met alle details zou weerspiegelen, zou de verwijzingscategorie slechts identieke materiële regels uit het buitenlandse rechtsstelsel kunnen selecteren ${ }^{1003}$. De verwijzingscategorie moet ruimer zijn dan een begrip van het materiële recht ${ }^{1004}$ zodat de lex fori geen exclusieve maatstaf kan zijn. Ook al is de lex fori geen exclusieve maatstaf, de lex fori is het uitgangspunt ${ }^{1005}$ voor de begripskwalificatie. Dit impliceert een onderscheid tussen de interne begrippen en die van de verwijzingscategorie ${ }^{10 * 6}$. De grondslag van de kwalificatie met verwijzingscategorieen valt niet samen mel de lex fori: het begrippensysteem van het rechtsstelsel waartoe de verwijzingsregel behoort ${ }^{1007}$. Als de lex fori uitgangspunt voor de begripskwalificatie is, is het de vraag welke buitenlandse begrippenstelsels betrokken mogen worden bij de precisering van de definitie van de verwijzingscategorie. Hoe en tot hoever moet de lex fori worden uitgebreid?

Mits men de betekenis van de verwijzingscategorieën niet reduceert tot die van het interne materièle recht van de lex fori, blijkt de ruime formulering van verwijzingscategorieèn eerder een voordeel dan een nadeel. De ruime verwijzingscategorie omvat niet alleen situaties die zijn beschreven met buitenlandse rechtsbegrippen die verschillen van de begrippen van de lex fori, maar ook situaties die daaraan onbekend zijn zoals in het

1002. Neuhaus, 123. Hiema blijft het standpunt volgens welk het vreende rechtsstelsel maatstaf is voor de kwalificatie, de zogeheten lex causae-opwatting; buiten beschouwing. Een belangrijk bezwaar tegen deze opvatting is dat deze kan leiden tot een te vermijden kwalificatieconflict: of. Strikwerda, 65 . Bovenduten is hier sprake van een petitio principii ondat slechts de voltooide kwallificatie de lex causae als maatstaf voor de kwalificatie zou kunnen bepaten: Makarov, 162; cf. Allarousse, 486; of. Firsohing/von Hoffmann, 203.

1003. Grundmann, 2; Mayer, 117-118.

1004. Schurig. 219. Cr. Rigaux 1984, 243: terminologische overeenkornsten tussen verwijzingscategorieën en interne begrippen zijn misleidend.

1005. Schurig, 220: 'Ausgangsbasis'.

1006. Cf. Kahn-Freund, 231 : "verlichte" lex fori-doctrine.

1007. Strikwerda, 64 . 
geval van de trust ${ }^{1008}$. De vraag is hoe verwijzingscategorieên in staat stellen tot kwalificatie van toedrachten die een aanspraak betreffen die slechts in een buitenlands rechtsstelsel bekend is ${ }^{1039}$. In het laatste geval moet het nationale kwalificatiebegrip worden gepreciseerd zonder hulp van de rechtsbegrippen omtrent de materiële regels van het rechtsstelsel waartoe de verwijzingsregel behoort ${ }^{1010}$. Dit bijzondere probleem is bijvoorbeeld ${ }^{1011}$ aan de orde bij de Anglo-Amerikaanse trust die als zodamig ${ }^{1012}$ in de Nederlandse materiële rechtsregels ontbreekt. De trust kan niet worden ondergebracht bij een in Nederland bekende rechtsfiguur ${ }^{1013}$. Als rechtsfiguren in het eigen rechtsstelsel onbekend zijn, moet de verwijzingscategorieèn een zekere autonomie worden toegestaan ten opzichte van de nationale rechtsbegrippen ${ }^{1014}$.

Kosters hanteert de lex fori als uitgangspunt. Volgens Kosters ${ }^{1015}$ moet bij de kwalificatievraag de toepasselijkheid van de lex fori het uitgangspunt vormen, maar niet meer dan dat. Hij aanvaardt de kwalificatie overeenkomstig de wet van de rechter, zij het onder vergaande reserves en beperkingen. Hij staat toe dat de kwalificatie zoals zij in het vreemde recht voorkomt, wordt gevolgd alls zij in de grond, in grote trekken, naar aard en wezen met de inheemse overeenkomt. Daarbij waarschuwt hij ertegen dat men strenge eisen stelt om te besluiten tot een soortgelijkheid van de vreemde met de eigen rechtsfiguur: dat er eenzelfde juridische constructie aanwezig is, wordt niet vereist. Volstaan kan worden met een gelijkheid in beginsel, in kern ${ }^{1016}$ en functie ${ }^{1017}$ of rechtsgevolg ${ }^{1013}$. Zelfs aanmerkelijke verschillen kunnen worden verwaarloosd als het gaat om uiteenlopende manifestaties van eenzelfde grondgedachte. Kosters staat toe

1008. Rigaux 1987, 233. Een strikte handhaving van de lex fori als uitgangspunt is niet vol te houden wanneer daarin een soontgelijke regel of instelling ontbreekt: cf. Beckett, 56 .

1009. Keller/Siehr, 437 .

1010. Cf. Firsching/von Hoffmann, 200.

1011. Een ander voorbeeld word genoemd door Rigax 1989, 166-167; wen nat Frans reclit toegelateri postuum huwelijk is onbekend in het Belgische recht.

10 2. Overigens kennen wij door de aanvataring van afgezonderde wermogens in de wom van bewind, v. $6 . f$. en kwalliteitsrekening, bijzondere rechtswerhoudingen met eenzelfde werking als de trust: cf. Cohen Henriquez 1986, 273; cf. Snijders, 233. Het gaat hier ont instachtige rechtsfiguren: Uniken Venema, 364-365; cf. 368. Zie echter Van Loon, 56-58; het bewind is geen receptie van de trust.

1013. Van Boeschoten 1993, 219; Van Boeschoten 1994, 5. Het Nederlandse recht verzet zich tegen het aanyaarden van een afgescheiden vermogen bij een overdacht in fiduciaire eigendom: Vegter, 630631; cf. Lipstein, 24 ; of. Strikwerda, 176.

1014. Neuhausi, 126 ; Strikwerda, 65.

1015. Kosters/Dubbink, 247-249.

1016. Kegel, 257 , noemt dit slechts een vuistregel.

1017. Ondat men volgens Kosters/Dubbink, 249 , geen strenge eisen moet stellen tert atanzien van de getijkheid van rechtsfiguren, zal het hier eerder om alternatieve dan om cumulatiewe criteria gaan.

1018. Kosters/Dubbink, 257. 
dat de verwijzingscategorieën een zekere autonomie bezitten ten opzichte van het begrippenstelsel van het materiële recht mits het gaat om soortgelijke rechtsfiguren. Deze soortgelijkheid kan onder meer een gelijkheid in functie zijn. De gelijkheid in functie is door een andere auteur ${ }^{1019}$ uitgewerkt voor materiele regels als voorwerp van begripskwalificatie. Volgens dit standpunt bevatten de verwijzingscategorieën essentialia die de verwijzingscategorieën van de lex fori geschikt maken ook die vreemde materiële regels die niet met de interne voorschriften overeenkomen, te omvatten voor zover die vreemde regels in functionele zin met de essentialia van de lex fori harmoniëren. De 'Funktionsgleichheit' tussen de lex fori en de voorschriften van het vreemde recht zijn beslissend; conceptuele of systematische gezichtspunten ten aanzien van de buitenlandse voorschriften kunnen daarbij buiten beschouwing blijven. De essentialia van de nationale rechtsinstelling vormen de maatstaf voor de kwalificatie van de vreemde materiële regels. Volgens het weergegeven standpunt blijft de lex fori uitgangspunt, zij het gereduceerd tot essentialia die een 'Funktionsgleichheit' met buitenlandse materiële regels kunnen manifesteren.

De essentialia van rechtsinstellingen worden gedistilleerd uit de functie die ze gemeenschappelijk bezitten in meer dan éen rechtsstelsel ${ }^{1020}$. Rechtsvergelijking is hier slechts hulpmiddel bij het kwalificeren ${ }^{102}$. Rechtsvergelijking voorziet in een additionele maatstaf ten opzichte van de lex fori. Een meer radicale benadering van de rechtsvergelijking als maatstaf komt in $\$ 3 . B$ aan de orde. In beide gevallen is sprake van 'rechtsvergelijkende begripskwalificatie in het IPR'.

\section{B. RECHTSVERGELIJKENDE GRONDSLAG}

Volgens Rabel is het tweeslachtig om enerzijds de lex fori als uitgangspunt te nemen en anderzijds rechisvergelijkend te werk te gaan om de definitie van de verwijzingscategorie nader te bepalen: de buitenlandse rechtsinstelling moet uitsluitend vanuit een rechtsvergellijkende grondslag bekeken worden ${ }^{1022}$. Rabel verenigt zijn consequente keuze voor de rechtsvergelijkende grondslag met zijn opvatting dat het voorwerp van begripskwalificatie uit "Lebensverhältnisse" bestaat. Hij staat toe dat deze feitelijke levenssituaties worden beschreven met juridische termen mits deze termen geschikt zijn voor

1019. Sandrock, 25-26; cf. Makarov, 160.

1020. Essser. 339 .

1021. Cf. Lemaire, 339. Cf: Robertson, 91: rechtsvergelijking als dienstknecht.

1022. Rabel 1931, 266-267: cf. Rabel 1931, 255. 
vreemde instellingen, zelfs indien die onbekend zijn aan de lex fori ${ }^{1023}$. Daarvoor is rechtsvergelijkend onderzoek nodig ${ }^{1024}$. Daarvan verwacht Rabel een gemeenschappelijke maatstaf voor de begripskwalificatie.

Rabel verlangt dat er verwijzingsregels opgesteld worden die zo mogelijk alle rechtsverschijnselen van de wereld omvatten, inciusief de constructies die vreend zijn aan de lex fori ${ }^{1025}$. Er zouden gemeenschappelijke rechtsbegrippen gevormd kunnen worden op een rechtsvergelijkende grondslag ${ }^{1026}$. Er is geen compleet, Internationaal classificatiesysteem voor het IPR ontwikkeld ${ }^{1027}$ dat onathankelijk is van de gezichtspunten voor de indeling van de verschillende nationale rechtsstelsels ${ }^{1028}$. Volgens Rabel is het noodzakelijk om eigen begrippen te ontwikkelen voor het systeem van het IPR ${ }^{1029}$; de daartoe vereiste abstractie ${ }^{1030}$ dient de rechtsvergelijkende methode te volgen ${ }^{1031}$. Dit is volgens hem noodzakelijk omdat de verwijzingscategorie geen betrekking heeft op een verschijnsel van de lex fori waarmee verschijnselen van vreemde rechtsstelsels gelijk gesteld zouden moeten worden, maar bij voorbaat op het gemeenschappelijke van deze juridische verschijnselen ${ }^{1032}$. Zijns inziens wordt de kwalifi-

1023. Rabel 1931, 249, verstaat onder de lex fori uitshitend de materiêle regels van het nationale recht van de rechter: Overigens verplaatsen andere juristen zich in de situatie van de rechter. Van Ginsbergen 1970,1 . De lex fori is de interne wet wan de rechter, of eventueel van een advocaat of notaris als er nog. geen geschil bij de rechter aanhangig is: Van Praag, 527, 541 noot 9

1024. Rabel 1958,55. Beckett, 59 noot 1, beweert onafhankelijk van Rabel tot hetzelfde standpunt te zijn gekomen.

1025. Rabel 1931,263; cf. Rabel 1931, 258, 282; cf Rabel 1958, 66. Overigens verwacht Rabel 1931, 267, van de rechter slechts dat hij het eigen rechtsstelsel met een beperkt aantal buitenlandse rechtsstelsels vergelijkt. Daarmee is het bezwaar wan Strikwerda, 66, niet weggenomen dat de rechter over onvoldoende tijd, kennis en middelen beschilkt om een dergelijk onderzoek te verrichten. Datzelfde bezwatr is te vinden bij Allarousse, 488; Collier, 19 en Robertson, 69; of. Lohse, 54; cf. Vranken, 134.

1026. Rabel 1931, 287; cr. Rabel 1931, 279; cf. Esser, 35. Volgens Kalin-Freund, 227, zou het kwalificatieprobleem verdwenen zijn met een arsenaal van rechtsbegrippen dat interwationale instemming zou genieten.

1027. Cf. Rabel 1931, 246: deze systeemworming staat nog in de kinderschoenen. Idealiter is bedoeld classificatiesy steem gebaseerd op een universelle kennis van alle mondiale rechtsstelsels: Wengler, 370 .

1028. Cf. Schurig, 215.

1029. Rabel 1931, 283. Cf. Rabel 1931, 268: het systeem van het IPR kan niet geleverd worten door fen nationaal rechtssysteem. Volgens Kotz (mondeling op 12-1-1996) zoekt Rabell naar een kwalificatie volgens het meest geschikte begrippenstelsel om gestalte te geven atan de beste juridische oplossing voor een sociaal probleem. Cf. Rabel 1931, 266-267; cf. Von Bar, 508.

1030. Van de nationale rechisbegrippen: Firsching/von Hoffmann, 204. Rabel ziet af van een identificatie van begrippen die tot verschillende rechtsstelsets behoren: Schurig, 222.

1031. Rabel 1931, 257; cf. Rabel 1931,267-268.

1032. Rabel 1931, 257, 263. 
catie niet door materièle regels bepaald maar door de conflictregels van de rechter ${ }^{1033}$; De autonome verwijzingscategorieên van het IPR zijn volgens Rabel onafhankelijk van de lex fori ${ }^{1034}$. Rabel wil de verwijzingscategorieën niet met de materiële regels van de lex fori concretiseren, maar met een gemeenschappelijke noemer van de materiêle regels van de werschillende rechtsstelsels ${ }^{1035}$. Gemeenschappelijk aan de verschillende materiële rechtsregels is dat zij dezelfde sociale functie vervullen ${ }^{1636}$. Een identieke functie wordt op haar beurt gepostuleerd door de situatie van het leven: Rabels voorwerp van begripskwalificatie ${ }^{1037}$.

Alleen op een rechtsvergelijkende grondslag zou de formulering mogelijk zijn van autonome verwijzingscategorieën die onafhankelijk zijn van de eigenaardigheden van de verschillende rechtsstelsels waaronder de lex fori ${ }^{1038}$ en die onafhankelijk zijn van de systematiek voor materiële regels ${ }^{1039}$. Met een rechtsvergelijkende grondslag wordt de lex fori als uitgangspunt voor de begripskwalificatie principieel verlaten. Er wordt eehter beweerd dat de doelstelling van Rabel niet volledig gerealiseerd kan worden ${ }^{1040}$. De opvatting dat begripskwalificatie op een algemene rechtsvergelijkende grondslag dient te berusten, is wellicht te beschouwen als een richtsnoer voor de vorming van conflictregels ${ }^{1041}$ die de beoogde mondiale verwijzingscategorieën bevatten. Dan is rechtsvergelijking eerder dienstbaar aan de regelgever dan aan de rechter. Een consequent rechtsvergelijkende grondslag is niet zonder meer een betere maatstaf dan de lex fori als uitgangspunt. Is het altijd een voordeel dat verwijzingscategorieën volledig zijn losgemaakt van de lex fori ${ }^{1042}$ ? De 'Funktionsgleichheit' met de lex fori kan tot eenzelfde resultaat leiden. Zonder radicale breuk met de lex fori is de begripskwalificatie weliswaar afhankelijk van de essentialia van de lex fori, maar niet uitsluitend: de essentialia van vreemde materiële regels zijn eveneens van belang.

1033. Rabel 1931, 249.

1034. Rigaux 1956, 147. Volgens Rabel 1931, 287, is er een cesur tussen de lex for enerzijds en de werwijzingsregels anderzijds. Niettemin erkent Rabel 1931,264 , een genetische afhankelijkheid wan de bestande werwijzingsregels ten opzichte wan de lex fort.

1035. Gundmanin, 34.

1036. Cr. Rigaux 1956,148, 153,154, 157 .

1037. Rigaux 1956, 150; cf. Rigaux 1956, 151 .

1038. Strikwerda, 65-66; cf. Heyn, 23; cf. Wengler, $355,374$.

1039. Kegel, 252.

1040. Audit 1991, 173; cf. Allarousse, 488 .

1041. Lemaire, 339.

1042. CF. Weber, 117-118. 
Begripskwalificatie op een rechtsvergelijkende grondslag kan worden toegepast in het geval van verdragen die conflictregels bevatten ${ }^{1043}$. Dan is rechtsvergelijking, anders dan bij Rabel, beperkt tot de rechtsstelsels van de verdragstaten ${ }^{\text {lo44 }}$. Verwijzingscategorieën in verdragen die conflictregels uniformeren, verlangen een verdragsautonome kwalificatie, dat wil zeggen: onafhankelijk van het nationale recht ${ }^{1045}$. Indien het verdrag een nauwkeurige definitie van een verwijzingscategorie bevat, behoeft er meestal geen kwalificerend begrip te worden gezocht ${ }^{1046}$. Dit geldt voor het Haagse Trustverdrag dat in artikel 2 aangeeft wat voor de toepassing van dit verdrag onder trust moet worden verstaan ${ }^{1047}$. Een rechtsinstelling die voldoet aan de kenmerken van artikel 2 geldt als verdragstrust; deze verdragsautonome kwalificatie vervangt de kwalificatie volgens de lex for ${ }^{1048}$ : het verdrag zet de nationale rechtsbegrippen opzij. Als de verwijzingscategorie in een verdrag gepreciseerd moet worden; moet er een kwalificerend begrip worden gezocht. Dan is de lex fori geen uitgangspunt; dan is rechtsvergelijking slechts hulpmiddel. De verdragsautonome kwalificatie berust niet alleen op een rechtsvergelijkende grondslag omdat het verdrag in kwestie eveneens grondslag is ${ }^{1049}$.

In het geval van een verdrag met gemeenschappelijke begrippen blijven er verschillen tussen de nationale kwalificaties indien een supranationale rechter ontbreekt ${ }^{1050}$. Dit frustreert een uniforme toepassing van het verdrag ${ }^{1051}$. Alleen een supranationale rechter zoals het Hof van Justitie te Luxemburg kan een autonome begripsvorming op rechtsvergelijkende grondslag bespoedigen ${ }^{1052}$. Aan dit Hof is de interpretatie van het EEX opgedragen ${ }^{1053}$. Deze supranationale rechter hanteert geen kwalificatie volgens de lex fori maar een verdragsautonome kwalificatie ${ }^{1054}$. Maatgevend zijn ener-

1043. Schwander, 140.

1044. Meyer, 132 .

1045. Kropholler 1994, 109; Schwander, 144.

1046. Cf. Firsching/von Hoffmarn, 202; cf. Rigaux 1987, 212, 233.

1047. Strikwerda, 177; cf. Herbots, 313-314; cf. Lipstein, 27. Nederland is sinds 1-2-1996 aangesloten bij het Haagse verdrag inzake bet recht dat toepasselijk is op trusts en inzake de erkenning van trusts:

Nederlands internationaall priwatrecht $1996,4849$.

1048. Van Boeschoten 1993,220; Van Boeschoten 1994, 14.

1049. Schlosshauer, 31: Schwimann, 15.

1050. Rigaux 1987, 331.

1051. Cf. Meyer, 119.

1052. Firsching/won Hoffmann, 204; cf. Audit 1993, 64; cf. Vranken, 135.

1053. Strikwerda, 254. Het EEX is een executieverdrag en behoort tot een ander hoofdonderdeel van het IPR dan het conflictenrecht: zie VI \& 1.A. Niettemin is het EEX illustratief voor de verdragsautonome kwalificative.

1054. Lohse, 39; cf. Strikwerda, 257. 
zijds doeleinden en systematiek van het verdrag en anderzijds algemene rechtsbeginselen van alle nationale rechtsstelsels ${ }^{1055}$. De kwalificatie op rechtsvergelijkende grondslag is echter problematisch bij een verdrag voor een groot antal staten ${ }^{1056}$. Zo worden er danzienlijke moeilijkheden verwacht ten aanzien van het onderscheid tussen roerende en ontoerende goederen gelet op de verschillen dienaangaande in de nationale rechtsstelsels ${ }^{1057}$. Het streven van Rabel naar uniforme verwijzingscategorieèn vindt zijn eindpunt niet in het opstellen van verdragen. Het stat bovendien niet vast dat deze verwijzingscategorieên uitsluitend op een rechtsvergelijkende grondslag gebaseerd kunnen worden. Afgezien van verdragen verdient de lex fori als uitgangspunt de voorkeur, mede gelet op de kritiek op Rabels voorwerp van begripskwalificatie ${ }^{1058}$.

\section{\$ 4. Verwijzingscategorie en materiële regels}

\section{A. VERSCHLLENDE BEGRIPPENSTELSELS}

Wanneer de definitie van de verwijzingscategorie voldoende is bepaald, is een kwalificerend begrip gevonden waaraan het te kwalificeren voorwerp moet voldoen. Aangenomen dat het te kwalificeren voorwerp uit nationale en buitenlandse materiële regels bestaat ${ }^{1059}$, moeten deze materiële regels de toepassingsvoorwaarden van de verwijzingscategorie vervullen. Om vast te stellen dat nationale en buitenlandse regels voldoen aan deze toepassingsvoorwaarden, moeten de eigenschappen van deze rechtsregels beschreven zijn. De beschrijving van in aanmerking komende rechtsregels is echter niet identiek wanneer de buitenlandse begripsindeling afwijkt van de nationale begripsindeling ${ }^{1062}$. Omdat de lex fori uitgangspunt is voor de begripskwalificatie ${ }^{1061}$ is de begripsindeling van de lex fori in eerste instantie bepalend voor de beschrijving van materiële rechtsregels, ook van de buitenlandse rechtsregels. De begripsindeling van de Lex fori bepaalt of buitenlandse rechtsregels bijvoorbeeld tot het alimentatierecht of het huwelijksgoederenrecht behoren ${ }^{1062}$. Dit geldt echter niet voor onbekende rechtsinstellingen warvoor een nationale begripsindeling ontbreekt ${ }^{1063}$, zoals voor de

1055. Lohse, 40; Strikwerda "257. Vranken; 136, acht dergelijke interpretatieregels vaag.

1056. Lohse, 54-5.5, 225 noot 95.

1057. Kropholler 1993, 165; cf. Stone, 355; cf. Strikwerda, 271.

1058. Zie VI.\$2.A.

1059. Zie VI. $\$ 2 . C$.

1060. Cl. Ancel, 244, 245. 247, 248.

1061. Zie VI. 3.A en VI. 3.B.

1062. Domer, 351 .

1063. Firsching/von Hoffmann, 202. 
trust ${ }^{1064}$. Over de problematiek van onbekende rechtsinstellingen gaat $\S 4$.B. Eerst is de moeilijkheid van afwijkende begripsindelingen aan de orde.

Problematisch is dat talloze buitenlandse rechtsregels niet passen in een ander systeem: de rechtsstelsels verschillen nogal in hun systematiek ${ }^{1065}$. De begripsindeling van de lex fori is veelal te beperkt. Dat blijkt uit het voorbeeld van de Franse "hypothèque judiciaire provisoire'. Bij vergelijking van deze Franse hypotheekvorm met het Nederlandse recht vallen elementen te ontdekken die gelijkenis vertonen met ons hypotheekrecht, maar ook bestanddelen die beschouwd kunnen worden als een vorm van conservatoir beslag op onroerend goed. Als zodanig is deze hypotheekvorm echter onbekend in het Nederlandse recht ${ }^{1066}$. Het probleem is hier dat de eigensehappen van de buitenlandse regel niet met de lex fori zijn te beschrijven ${ }^{1067}$. Afwijkende begripsin" delingen leiden tot een discrepantie in beschrijvingen van in aanmerking komende materiële regels. Een autonoom begrippenstelsel kan een oplossing bieden.

Een autonome begripsindeling is aanwezig in de dichotomie 'movable' of 'immovable'; een indelling die het Engelse IPR heeft ontwikkeld als een systeem parallel aan dat van het interne recht: 'personalty" of 'realty" ${ }^{0668}$. Het onderscheid tussen 'real' en "personal property' werd ongeschikt geacht voor het conflictenrecht, in tegenstelling tot het begrippenpaar 'immovable' en 'movable property' dat op internationale instemming zou mogen rekenen ${ }^{1069}$ : De autonome begripsindeling 'movable'/ 'immovable' komt voort uit de constatering dat de begripsindeling van het Engelse interne recht geen absolute of universele waarde heeft ${ }^{1070}$. Het begrippenpaar 'movable'/. immovable' bevat criteria die op begrippenstelsels van de civil law toegepast kunnen worden ${ }^{1071}$; het is een bescheiden aanzet tot een alomvattend classificatiesysteem voor het IPR.

1064. Zie VI.\$3.A.

1065. Rabel 1931,255, 266.

1066. Vlas, 249, 252. Overigens acht Vlas, 253, inpassing overbodig oundat hij all heeft geconcludeerd dat de situswet krachtens artikel 7 Wet $\mathrm{AB}$ voorrang heeft aangezien in het besprolken geval het onroerend goed in Frankrijk ligt. Cf. Strikwerda 53 : deze conflictregell laat geen beoorelelingsruinte toe. De eigen verwijzingsregel werwijst bij voorbaat naar de kwalificatie aan de hand wan het vreende rechtsstelsel: cf. Audit 1991, 174. Daarom is er geen aanleiding cm te trachten clit niar Frans recht geschapen zakelijk recht te passen in het Nederlandse gesloten systeem wan zakelijke rechten: Wlas, 253.

1067. Cf. Heyn, 26-27.

1068. Kosters/Dubbink, 246: het gaat hier om verschillende tegenstellingen. Cf. Collins, 916; of. Robertson. 195; cf. Sitone, 352.

1069. Kahn-Freund, 229; North/Fawcett, 46, 779; of. David 1980, 35; cf. Collier, 21.

1070. Rigaux 1956, 274-276.

1071. Zie III.\$ 3.B. 


\section{B. ONBEKENDE RECHTSINSTELLINGEN}

Rechtsinstellingen zoals de trust en de "mahr" hebben geen bekende plaats in de begripsindeling van het rechtsstelsel dat die rechtsinstellingen mist ${ }^{1072}$. Afwijkende begripsindelingen zijn dan niet aan de orde ${ }^{10 \% 3}$. Het functionele gezichtspunt heet onmisbaar voor die gevallen dat door het wreemde materiële recht rechtsinstellingen zijn gecreëerd die ontbreken in het nationale materiële recht ${ }^{1074}$. Vanuit het functionele perspectief wordt gevraagd naar de functie die de te kwalificeren rechtsregel vervult in het buitenlandse rechtsstelsel ${ }^{1075}$. De lex fori is geen uitgangspunt voor rechtsvergelijkende overwegingen omtrent een onbekende buitenlandse rechtsinstelling ${ }^{1076}$. Het is de vraag welke eigenschappen van de in aanmerking komende regels essentieel zijn in het licht van een functiebegrip dat op een onbekende rechtsinstelling wordt toegepast. Daarom wordt eerst ingegaan op de intensie ${ }^{1077}$ waaraan functionele eigenschappen van rechtsregels zouden moeten beantwoorden. Daarna volgen de bijzondere moeilijkheden van de kwalificatie van een onbekende rechtsinstelling die meer functies heeft.

Het functiebegrip is ruimer dan de begrippen van een rechtsstelsel; bovendien kan het onafhankelijk daarvan en tot op zekere hoogte neutraal ${ }^{1078}$ worden geformuleerd ${ }^{1079}$. Het functiebegrip komt tot stand door te abstraheren van de "interne Rechtsgliederung" ${ }^{1080}$. Het is echter de vraag van welke aard bedoelde functies zijn: gaat het om functies die materiële regels moeten vervullen omdat de samenleving dat; al dan niet bij monde van de wetgever ${ }^{1081}$, heeft bepaald? Gaat het om rechtspolitieke functies ${ }^{1082}$ ? Of gaat het om technische functies ${ }^{1083}$ ? Er blijkt geen consensus uit de literatuur. Volgens Esser ${ }^{1084}$ gaat het bij een aan meer rechtsstelsels gemeenschappelijke functie zowel om 'Aufgabe" 1085 als on 'Wirkungsweise'. In andere

1072. Cr. Gnundmann, 43.

1073. Cf. Grundmann, 4.

1074. Schlosshauer, 31 .

1075. Heyn, $27-28$.

1076. Meyer, 113 .

1077. Zie II. 1.

1078. Cf. Schuyt 1986,11 .

1079. Schwind, 488,491 .

1080. Esser, 338 ; cf. Esser, $352,359,363$.

1081. Cf: Rabel 1958, 66 .

1082. Schlosshaner, 30 .

1083. Schwind, 485, onderscheidt technische en teleollogische functies. $\mathrm{Cf}$. Schwind, 489.

1084. Esser, 339; cf. Esser, 348-349, 352-354, 357.

1085. Gamillscheg, 80. Cf. Meyer, 130: 'Ordnungsziel', Cf, Meyer, 131: 'Ordnungsfunktion'. 
woorden: het gaat on "Normzweck' èn 'Normwirkung" ${ }^{1086}$ "om juridische intentie èn sociaal effect van een rechtsregel. De opvatting van Esser impliceert dat zijn functiebegrip twee verschillende intensies bevat; zijn functiebegrip is meerduidig evenals dat

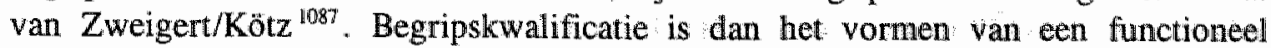
soortbegrip op een zodanige wijze dat materiële rechtsregels tot de extensie van dat soortbegrip behoren ${ }^{1088}$. Ondat dit soortbegrip de kenmerken 'Normzweck' en 'Normwirkung' verbindt ${ }^{1089}$, moeten de in aanmerking komende rechtsregels aan beide kenmerken voldoen om tot de extensie van de verwijzingscategorie te behoren. Overigens is onduidelijk welke intensie het functiebegrip heeft. Dit bemoeilijkt de kwalificatie van een rechtsinstelling die onbekend is in de lex fori.

Een buitenlandse rechtsinstelling die als zodanig onbekend is in het nationale recht, is het islamitische huwelijksgeld ${ }^{1090}$. Dit is geen schenking maar een schuld ${ }^{1091}$. Het islamitische huwelijksgeld ('mahr") ${ }^{1092}$ is een vóór de huwelijkssluiting overeengekomen bedrag dat de bruidegom zijn vrouw moet betalen. Eerst na de feitelijke voltrekking van het huwelijk is het volledige bedrag verschuldigd ${ }^{1093}$. Daarmee heeft het islamitische huwelijksgeld vooreerst de functie van voorwaarde voor de geldigheid van een huwelijk. Daarnaast zijn er nog vier functies te onderkennen: het bemoeilijken van scheiding door verstoting ("talaq"); het waarborgen van het levensonderhoud van de echtgenote; het voorzien in een financiële schadeloosstelling aan de vrouw in het geval van een echtscheiding; en het bieden van verzorging aan de vrouw na de dood van haar man ${ }^{1094}$. De twee laatstgenoemde functies zou men ook kunnen aanduiden als de alimentatieve functie respectievelijk de erfrechtelijke functie van het islamitische huwelijksgeld ${ }^{1095}$, ofschoon deze benaming suggereert dat de functie door een groepering van rechtsregels wordt bepaald. De probleemoplossingen die in de 'mahr' zijn verenigd, zijn afzonderlijk herkenbaar in een westers begrippensteisel; de samenhang van deze pro-

1086. Hoppe, 141 .

1087. Zie III \& 2.A.

1088. Zie VI.\& 2.C.

1089. Zie II. \& 1 .

1090. Schlosshauer, 31. Von Bar, 500; het Duitse materiele recht kent het huwelijksgeld niet. Zo ook BGH 28-1-1987, Neue Juristische Wochenschrift 1987, p. 2161-2164: voor dit "eigenwilliges Rechtsinstitut... für das es in deutschen. Recht kein unmittelbar passendes Gegenstück gibł' komen een al imentatieve, een goederenrechtelijke en een erfrechtelijke functie $c . q$. kwalificatie in anmmerking.

1091. Suddiqui, $21-22$.

1092. Ook met "bruidsschat' vertald: De Groot 1979, 364

1093. Bergmann/Ferid, 11-12; Juynboll. 181-182; cf. Siddiqui, 20.

1094. Heyn, 52 .

1095. De Groot 1979, 364-366. Volgens De Groot 1979, 365, behoort het islamitische instinut vant de bruidsschat tot het huwelijksgoederenrecht. 
bleemoplossingen die kenmerkend is voor de 'mahr' ontbreekt echter in westerse begrippenstelsels ${ }^{1096}$.

Als een rechtsinstelling zoals het islamitische huwelijksgeld meer functies kan manifesteren ${ }^{1097}$, is het de vraag welke functie de primaire functie is. De beantwoording van deze vraag is van belang omdat een veelheid wan functies de keuze van een verwijzingscategorie bemoeilijkt. Er wordt echter ontkend dat een veelheid van functies beperkt kan worden tot éen primaire functie zonder het feitencomplex daarbij te betrekken ${ }^{1098}$. Als het feitencomplex ook gekwalificeerd moet worden, is de kritiek op het prejuridische voorwerp van begripskwalificatie van toepassing ${ }^{1099}$ : een feitencomplex dat in het geheel niet aan rechtsregels is gerelateerd, is onhanteerbaar. Zou het feitencomplex wèl aan rechtsregels gerelateerd worden, dan is de nationale begripsindeling irrelevant omdat de 'mahr' als zodanig ontbreekt in de begripsindeling van de lex fori. Bij een veelheid van functies blijft de verwijzingscategorie vaag zodat het niet mogelijk is om bijvoorbeeld het islamitische huwelijksgeld met een neutraal functiebegrip te kwalificeren. Een uitweg wordt hier geboden door het opstellen van nieuwe verwijzingscategorieën ${ }^{1100}$ op een rechtsvergelijkende grondslag ${ }^{101}$ en na kritische waardering van de juridische oplossingen die worden geboden door de in aanmerking komende rechtsstelsels.

1096. Er is geen uniwerseel functiebegrip dat de "malır" omvat: zie III.\& 3.A slot.

1097. Firsching/von Hoffmann, 200; cf. Schwimann, 16.

1098. Cf. Heyn, 58,78 .

1099. Zie VI. 2.A.

1100. Robertson, 84-85.

1101. Zie VI. 3.B. 


\section{Conclusies}

\section{\$1. Direct nut van comparatieve begrippen}

\section{A. ONZEKERHEID IN DE LITERATUUR}

In dit hoofdstuk worden conclusies geformuleerd op basis van de voorafgaande hoofdstukken. In $\& 1$ staan conclusies omtrent het directe nut van comparatieve begrippen. In $\$ 2$ volgen conclusies omtrent het indirecte nut voor de drie toepassingsgebieden van comparatieve begrippen. De laatste paragraaf van dit hoofdstuk meldt mogelijkheden van verder onderzoek naar comparatieve begrippen.

De relevante literatuur laat onzekerheid zien omtrent de plaats van comparatieve begrippen in de rechtsvergelijking. Zweigert/Kötz en Kokkini beweren dat comparatieve begrippen nuttig zijn in de beginfase van het rechtsvergelijkend onderzoek; Constantinesco beperkt het directe nut van comparatieve begrippen tot de eindfase ${ }^{1802}$. Constantinesco en Rozmaryn verwerpen comparatieve begrippen die op voorhand gemeenschappelijke elementen selecteren uit verschillende rechtsstelsels ${ }^{1103}$. Zweigert/KötZ beweren dat uitsluitend functiebegrippen nuttig zijn voor het rechtsvergelijkend onderzoek; Kokkini ruimt ook plaats in voor een andere benadering "104: de immanente begripsvorming van Eltzbacher of de extensionele begripsvorming van Rozmaryn. Constantinesco levert kritiek op de functionele begripsworming van Drobnig en Zwei-

1102. Zie II.\$2.A en II. \$ 3.C.

1103. Zie III.S 2.A.

1104. Zie II. 4. B. 
gert/Kötz ${ }^{105}$. Mincke staat slechts immanente begrippen toe die zuiver gemeenschappelijk zijn ${ }^{10}$ terwij1 Eltzbacher ruimte laat voor gedeeltelijk verschillende begrippen ${ }^{1107}$. Mincke acht alleen zuiver gemeenschappelijke begrippen mededeelbaar; Kokkini en Drobnig huldigen het standpunt dat ook gedeeltelijk verschillende begrippen weergegeven kunnen worden ${ }^{108}$. Naast soortbegrippen is er incidenteel sprake van typebegrippen: ten onrechte bij Sacco ${ }^{1109}$; terecht bij Drobnig ${ }^{110}$.

De relevante literatuur laat voorts onzekerheid zien omtrent het nut van comparatieve begrippen: alleen Kokkini is uitgesproken positief omtrent het directe nut ${ }^{111}{ }^{2}$. Het nut van comparatieve begrippen is onder meer verdedigd met desiderata omtrent classificatiesystemen ${ }^{11: 2}$. Deze desiderata bieden geen zekerheid omtrent het nut van comparatieve begrippen voor het rechtsvergelijkend onderzoek.

In dit proefschrift is getracht de onzekerheid in de literatuur te verminderen met de volgende aanpak: er zijn onderzoeksactiviteiten onderscheiden waarvoor comparatieve begrippen nuttig kunnen zijn; er is telkens geïnventariseerd welke voorwaarden vervuld moeten worden voor het nut van comparatieve begrippen ${ }^{113}$. Bovendien is er een onderscheid gemaakt tussen het functiebegrip van Zweigert/Kötz en dat van Drobnig: het eerste functiebegrip heeft betrekking op het sociale effect van rechtsregels, het tweede op de juridische intentie ervan 1114. In dit proefschrift is geconcludeerd dat een comparatief begrip een tertium comparationis is: een criterium voor de vergelijkbaarheid van rechtsregells ${ }^{1115}$. Deze vergelijkingsbasis is nuttig voor het rechtsvergelijkend onderzoek. Daaraan is als noodzakelijke voorwaarde verbonden dat het vergelijkbaarheidsoordeel toetsbaar is ${ }^{1116}$.

1105. Zie II.\$2.A en II. \$3.C

1106. Zie II. $\$$ 4.A.

1107. Zie Il.\& 3.A.

1108. Zie II. 4 .A en II.\$ 4.B.

1109. Zie II.8 3.A.

1110. Zie II. 2.A en III. $\$ 2 . B$.

1111. Zie 11 2.A en II.\$ 4.B.

1112. Zie 11.2 .A en II. $\$ 2 . B$.

1113. Zie III.\$1.

1114. Zie III. 2.A en III. \& 2.B.

1115. Zie III. 1 en III. \$2.A.

1116. Zie III.\$1. 


\section{B. VOORWAARDEN VOOR DIRECT NUT}

De toetsbaarheid van het vergelijkbaarheidsoordeel is bepalend voor het empirisch nut van comparatieve begrippen. Aan deze noodzakelijke voorwaarde wordt niet voldaan door intuïtieve begrippen. Comparatieve begrippen moeten bovendien eenduidig zijn vanaf het begin van het rechtsvergelijkend onderzoek ${ }^{117}$. Een noodzakelijke voorwaarde voor het empirisch nut van comparatieve begrippen is dat zij eenduidig zijn. De extensionele begripsvorming van Rozmaryn voldoet hieraan niet en is verworpen in dit proefschrift. De opsomming van rechtsregels die gemeenschappelijk zijn aan een aantal rechtsstelsels bepaalt niet eenduidig in welk opzicht rechtsregels vergelijkbaar worden geacht. Vergelijkbaarheid is niet gegeven met de rechtsregels waarop een rechtsvergelijkende methode wordt toegepast. Dit leidt tot het verwerpen van het standpunt van Constantinesco dat comparatieve begrippen alleen voor de eindfase nuttig zouden zijn. De vorming van comparatieve begrippen is nuttig voor het formuleren van een eenduidige uitgangshypothese.

Een vergelijkbaarheidsoordeel met het functiebegrip van Zweigert/Kötz is moeilijk te toetsen ${ }^{1118}$. Het oorzakelijk verband tussen specifieke rechtsregels en het oplossen van een sociaal probleem is moeilijk vast te stellen. Het functiebegrip van Zweigert/Kötz berust meestal op een vereenwoudigde voorstelling van de sociale werkelijkheid. Dit functiebegrip is wellicht woldoende voor een verkennend onderzoek naar een sociaal probleem waarvoor juridische belangstelling bestaat, of om te voorkomen dat bijvoorbeeld adoptieregelingen en antitrustregelingen worden vergeleken. De kritiek van Constantinesco op het functiebegrip van $Z$ weigert/Köt $Z$ is terecht; Zweigert/Kötz hebben die kritiek niet weerlegd ${ }^{119}$. Hun functiebegrip heeft veelal geen empirisch nut.

De toetsbaarheid van een vergelijkbaarheidsoordeel met een immanent begrip wordt bepaald door de vergeleken begrippenstelsels ${ }^{120}$. Als het butenlandse begrippenstelsel niet dezelfde samenhang heeft als het eigen begrippenstelsel, wordt het vaststellen van een gemeenschappelijke juridische intentie bemoeilijkt. Het Franse en Engelse goederenrecht zijn qua structuur te verschillend om een gemeenschappelijk kenmerk toe te laten. Min of meer overeenkomstige begrippenstelsels zijn een noodzakelijke voorwaarde voor het empirisch nut van immanente begrippen. Deze voorwaarde geldt niet voor het functiebegrip van $Z$ weigert/Kötz dat de nationale begrippenstelsels buiten 
beschouwing laat ${ }^{1121}$, maar dit functiebegrip is meestal onbruikbaar voor rechtsvergelijkend onderzoek.

Voor alle onderzoeksactiviteiten gelden de noodzakelijke voorwaarden dat comparatieve begrippen eenduidig zijn ${ }^{1122}$ en dat het vergelijkbaarheidsoordeel niet is weerlegd ${ }^{1123}$. Aan deze noodzakelijke voorwaarden moet voldaan zijn voor het beschrijven van overeenkomsten tussen rechtsstelsels en voor de presentatie van voltooid onderzoek. Deze onderzoeksactiviteiten berusten op een vergelijkbaarheidsoordeel; ze zijn medebepalend voor het nut van comparatieve begrippen ${ }^{1124}$.

De beschrijving van overeenkomsten of gelijkenissen tussen rechtsregels is een andere activiteit dan het toetsen van een vergelijkbaarheidsoordeel. Voor deze beschrijving zijn immanente begrippen nuttig, het functiebegrip van Zweigert/Kötz niet. Dit functiebegrip is onvoldoende specifiek voor het beschrijven van overeenkomsten van rechtsregels van verschillende rechtsstelsels. Het bezwaar van Constantinesco dat functiebegrippen te globaal zijn, treft de immanente begripsvorming niet ${ }^{1125}$. Zijn kritiek is niet van toepassing op het immanente typebegrip van Drobnig, want dit begrip is voldoende specifiek voor de beschrijving van gelijkenissen in juridische intenties. Immanente begrippen die gedeeltelijk verschillend zijn, zijn voldoende voor het beschrijven van rechtsregels, maar ongeschikt voor het verklaren van dogmatische verschillen tussen rechtsstelsels. Deze verklaring streeft Mincke na met zuiver gemeenschappelijke begrippen. Immanente begrippen zijn veelal onbruikbaar voor deze onderzoeksactiviteit. Het streven van Mincke leidt tot een beperking wan het rechtsvergelijkend onderzoek die niet gekozen behoeft te worden.

De presentatie van voltooid onderzoek kan geschieden met een rechtsvergelijkend classificatiesysteem of met een eenduidige terminologie ${ }^{1126}$. Comparatieve begrippen zijn noodzakelijke bouwstenen voor een rechtsvergelijkend classificatiesysteem. Deze begrippen bevatten echter geen criteria voor de afbakening van vergelijkbare rechtsstelsels in rechtsfamilies. Comparatieve begrippen zijn onvoldoende voor de indeling van een rechtsvergelijkend classificatiesysteem. Uit de analyse van rechtsvergelijkende ordeningssystemen ${ }^{1127}$ kan worden afgeleid dat het absoluut-autonome systeem van Zwei-

1121. Zie II. \$ 3.C.

1122. Zie III 8 .A.

1123. Zie III. $\$ 2 . B$ en III. $\$ 4 . A$.

1124. Zie III \$1.

1125. Zie III $\$ 2 . B$.

1126. Zie III. \$ 4.A en III.\$4,B.

1127. Zie IV.\$1,B,IV.\$2,A, IV, 2 B en IV. \&4.C. 
gert/Kötz overzichtelijk is, maar minder specifiek dan het relatief-autonome systeem van Drobnig.

Comparatieve begrippen zijn eveneens onvoldoende voor het ontwikkelen van een eenduidige terminologie. Hierop moet een uitzondering worden gemaakt: synonieme termen voor zuiver gemeenschappelijke begrippen zijn zonder meer eenduidig. Overigens zijn comparatieve begrippen onvoldoende om verwarring met nationale rechtstermen te voorkomen. Het maken van aanvaardbare afspraken is nodig in het geval van gedeeltelijk verschillende begrippen. Nummers van een rechtswergelijkend classificatiesysteem zijn het meest geschikt voor deze afspraken; nationale of nieuwe termen zijn minder trefzeker voor de vergelijkende betekenis van een comparatief begrip. Termen uit een omgangstaal zijn ongeschikt, ook al geven Zweigert/Kötz daaraan de voorkeur. In het algemeen zijn comparatieve begrippen onvoldoende om misverstanden omtrent voltooid onderzoek te voorkomen.

Vanaf het begin van het rechtsvergelijkend onderzoek genieten immanente begrippen de voorkeur boven de functiebegrippen van Zweigert/Kötz. Comparatieve begrippen zijn niet altijd voldoende voor het beschrijven van rechtsregels van verschillende rechtsstelsels; of voor het voorkomen van misverstanden omtrent voltooid onderzoek.

\section{$\$ 2$. Indirect nut van comparatieve begrippen}

\section{A. RECHTSVERGELIJKENDE ORDENINGSSYSTEMEN}

Het indirecte nut van comparatieve begrippen wordt in deze paragraaf bepaald voor rechtsvergelijkende ordeningssystemen en in $\S 2$.B voor rechtsvergelijkende thesauri. In \$ 2.C volgt het indirecte nut van comparatieve begrippen voor de rechtsvergelijkende begripskwalificatie in het internationaal privaatrecht, het derde toepassingsgebied. Voor het nut van comparatieve begrippen voor deze toepassingsgebieden is vereist dat deze gebieden rechtsvergelijkende momenten bevatten, maar geen beperkingen die de toepassing van comparatieve begrippen verhinderen. Als deze beperkingen ontbreken, kunnen er conclusies worden getrokken omtrent het indirecte nut van comparatieve begrippen. Dit gebeurt aan de hand van twee maatstaven: de relevantie van documenten gevonden met een ordeningssysteem of thesaurus; en de precisie van de definitie van de verwijzingscategorie in het geval van de begripskwalificatie ${ }^{1 / 28}$.

1128. Zie III.\$ 5.B. 
Ordeningssystemen bevatten rechtsvergelijkende momenten waar vergelijkbare rechtsstelsels gegroepeerd worden. Dit is woor een aantal ordeningssystemen het geval. De afbakening van de common law door Moys ${ }^{1129}$ berust op de vergelijking van rechtsstelsels. Dit geldt ook voor de criteria die Steiner ${ }^{130}$ heeft ontwikkeld voor de verwantschap van rechtsstelsels en voor de regionale modelclassificaties van de LCC. Deze ordeningssystemen van de LCC bevatten ook rechtsvergelijkende momenten waar voor onderdelen van rechtsstelsels bepaald is dat de 'essentie van het dogma' hetzelfde is ${ }^{1131}$. Rechtsvergelijking is echter geen hulpmiddel voor de constructie van ordeningssystemen waarmee documenten omtrent de civil law worden geforceerd in categorieën van de common law ${ }^{1132}$. Rechtsvergelijkende momenten ontbreken eveneens in het ordeningssysteem van Schiller die hiërarchische relaties binnen rechtssystemen verwaarloost ${ }^{1133}$. Niettemin is gebleken dat rechtsvergelijking kan bijdragen aan de constructie van ordeningssystemen.

De hiërarchische relaties van een ordeningssysteem moeten zoveel mogelijk aansluiten bij die van de rechtssystemen waarop het ordeningssysteem betrekking heeft ${ }^{1134}$. In het geval van polyhiêrarchie leidt dit beginsel tot beperkingen die de toepassing van comparatieve begrippen in ordeningssystemen beletten. Dit is toegelicht aan de hand van het immanente begrip 'appartementsrecht" "1135. Dit comparatieve begrip kan niet worden toegepast in een ordeningssysteem. Immanente begrippen die in verschillende rechtsgebieden ingedeeld worden, hebben geen nut voor ordeningssystemen. Het indirecte nut van comparatieve begrippen voor rechtsvergelijkende ordeningssystemen is beperkt.

Waar hiërarchische relaties van een ordeningssysteem niet beperkend zijn, kan met een immanent begrip worden bepaald waar een rechtsvergelijkend classificatiebegrip met een gemeenschappelijke notatie is toegestaan, en waar niet. Een ordeningssysteem dat uitsluitend berust op sociale problemen, voldoet daarentegen niet aan de maatstaf dat relevante documenten worden gevonden want de functiebegrippen van Zweigert/Kötz

1129. Zie IV. 4 A.

1130. Zie IV.\$ 4.8 .

11.31. Zie IV. \$.A en IV.\$ 5.B.

1132. $2 \mathrm{ie} \mathrm{IV. \& 3.C}$

1133. Zie IV.\& 3.B.

1134. Zie IV.\$2.A, IV. 3.B en IV.\$ 5.C.

1135. Zie IV 2.B. 
zijn te globaal ${ }^{1136}$. Voor rechtsvergelijkende ordeningssystemen genieten immanente begrippen de voorkeur boven de functiebegrippen van Zweigert/Kötz.

\section{B. RECHTSVERGELUKENDE THESAURI}

Rechtsvergelijking is hulpmiddel voor de constructie van meertalige thesauri indien de relatieve identiteit van nationale rechtsbegrippen bepaalt waar synonieme descriptoren in nevenschikkende relaties worden vastgelegd ${ }^{1137}$. De nevenschikkende relaties van een thesaurus leveren geen beperkingen op voor de toepassing van comparatieve begrippen: quasi-synoniemen voor immanente begrippen die niet zuiver gemeenschappelijk zijn, kunnen equivalent verklaard worden. Eventuele hiërarchische relaties ${ }^{1138}$ zijn evenmin beperkingen: 'adoptie' kan de hogere descriptor ${ }^{139}$ zijn voor de meer specifieke descriptoren 'sterke adoptie' en 'zwakke adoptie' ${ }^{3} 140$. Een hiërarchische relatie tussen descriptoren sluit echter een nevenschikkende relatie tussen diezelffle descriptoren uit ${ }^{1141}$. Aan deze gecombineerde beperking van thesauri is de toepassing van comparatieve begrippen onderworpen. Het is echter niet noodzakelijk dat een thesaurus hiërarchische relaties bevat ${ }^{1 / 42}$.

Er zijn beperkingen ten aanzien van de woorden die worden toegelaten als descriptor omdat een descriptor zo eenduidig mogelijk moet zijn ${ }^{143}$. Rechtstermen zoals 'Pflichtteilsberechtigter' die door het Duitse rechtsstelsel in een andere betekenis worden gebruikt dan door het Zwitserse rechtsstelsel ${ }^{1144}$, zijn niet eenduidig. De toepassing van comparatieve begrippen die door meerduidige rechtstermen worden weergegeven, is beperkt door het streven naar eenduidige begripsrepresentatie. De beperking voor meerduidige rechtstermen geldt niet voor elementaire rechtstermen met een absoluut identieke betekenis. Elementaire rechtstermen worden bovendien niet gehinderd door de beperking van meertalige thesauri dat woordsamenstellingen zoveel mogelijk gesplitst moeten worden ${ }^{1145}$. Elementaire rechtstermen zijn bij uitstek geschikt voor de con-

1136. Zie III.\& 2.B. De 'systemfreie problemorientierte Klassifikanion' van Kreuzer (IV. 8 4.C) berust niet alleen op sociale problemen omdat functiebegroppen ondergeschikt zijn aan immanente rechtsgebieden.

1137. Zie V.\$1.A, V.\$4.A en V.\$4.C.

1138. Zie V.\& I.B.

1139. Zie V.\$4.B.

1140. Zie hoofdstuk I en MI. \& 2.B.

1141. Zie V. 1 .A.

1142. Zie V.\$1.B.

1143. Zie W $\$$ IA

1144. Zie V.\$4.A.

1145. Zie V.\$4.A. 
structie van een meertalige thesaurus, het desideratum van De Wild ${ }^{1 / 46}$. Comparatieve begrippen waarvoor een eenduidige terminologie is afgesproken ${ }^{147}$ worden toegelaten in een thesaurus die national-specifieke uitdrukkingen vervangt ${ }^{1148}$, bijvoorbeeld door nummers wan een rechtsvergelijkend classificatiesysteem ${ }^{1449}$. In het laatste geval dragen comparatieve begrippen bij aan de constructie van een uniforme thesaurus, het desideratum van De Groot ${ }^{1150}$.

Een tweede beperking ten aanzien van de woorden die worden toegelaten als descriptor is dat de descriptor een courante rechtsterm moet zijn ${ }^{151}$. Dit belet de toepassing van functiebegrippen in een thesaurus, want deze begrippen zijn in een omgangstaal geformuleerd ${ }^{1152}$. De functionele woordgroep "judicial review of administrative acts $^{* 1153}$ is ongeschikt yoor een thesaurus, ook omdat ze onvoldoende precies is voor een eenduidige terminologie. Overigens zijn courante rechtstermen veelal geen synoniemen ${ }^{1154}$, maar quasi-synoniemen; zij leiden tot een geringere precisie van de vangst van een zoekactie dan met elementaire rechtstermen mogelijk is ${ }^{1155}$.

Immanente begrippen hebben beperkt nut yoor rechtsvergelijkende thesauri door te bepalen waar nevenschikkende relaties tussen quasi-synoniemen zijn toegestaan. Daarmee wordt bevorderd dat relevante documenten worden teruggevonden met een descriptor. Elementaire rechtstermen voor zaiver gemeenschappelijke begrippen hebben het grootste nut woor thesauri. Overigens hebben immanente begrippen beperkt nut. Het functiebegrip van Zweigert/Kötz heeft geen indireet nut voor rechtsvergelijkende thesauri.

\section{RECHTSVERGELIJKENDE BEGRIPSKWALIFICATIE IN HET IPR}

Het derde toepassingsgebied van comparatieve begrippen is de begripskwalificatie in het internationaal privaatrecht (IPR). Deze begripskwalificatie bevat rechtsvergelijkende momenten omdat de lex fori niet exclusief bepalend mag zijn woor de definitie van de

1150. Zie II.\$ 2.B.

1151. Zie V.S3.A.

11.52. Zie III.\& 4.B.

1153. Zie V.\$4.B.

1154. Zie III. 8 .B.

1155. Zie V. $2 . B$ en V. 4 .C. 
verwijzingseategorie ${ }^{1156}$ : een buitenlands rechtsstelsel moet betrokken worden bij de rechtsvergelijkende begripskwalificatie in het IPR. Daartoe is rechtsvergelijking een hulpmiddel. Aan de literatuur zijn echter drie beperkingen te ontlenen die het indirecte nut van comparatieve begrippen illusoir kunnen maken:

(a) de formulering van de verwijzingscategorie in nationale rechtstermen;

(b) het beperkte aantal verwijzingscategorieën;

(c) de verwijzingscategorie is een soortbegrip.

Ad (a) De formulering van de verwijzingscategorie is geen beperking voor de toepassing van comparatieve begrippen ten behoeve van de begripskwalificatie, omdat de verwijzingscategorie niet alleen nationale maar ook buitenlandse rechtsregels omvat ${ }^{1157}$. De rechtstermen in de verwijzingscategorie hebben een vergelijkende betekenis.

Ad (b) Het beperkte aantal verwijzingscategorieèn is een relevante beperking indien zij de kenmerken van comparatieve begrippen missen. Deze beperking wordt terzijde gesteld door het toestaan van autonomie ten opzichte van de nationale rechtsbegrippen ${ }^{1158}$. Zo is in het Engelse IPR het interne onderscheid tussen 'personalty' en 'realty' vervangen door het autonome begrippenpaar 'movable' en 'immovable" 1159 .

Ad (c) De vorm van de verwijzingscategorie is geen geldige beperking voor de toepassing van een comparatief begrip. Het is niet noodzakelijk dat de verwijzingscategorie een soortbegrip is. In welke gevallen de verwijzingscategorie een typebegrip kan zijn, is een onderwerp voor verdere studie ${ }^{1160}$.

De verwijzingscategorie bevat gemeenschappelijke kenmerken, maar is geen kwalificerend begrip omdat de verwijzingscategorie gepreciseerd moet worden ${ }^{1161}$. De precisering van de definitie van de verwijzingscategorie kan geschieden met immanente begrippen. Immanente begrippen hebben indirect nut voor de begripskwalificatie indien hun gemeenschappelijke kenmerk verbonden kan worden met dat van de verwijzingscategorie zodat een verfijnd comparatief begrip als verwijzingscategorie optreedt. In het geval van min of meer overeenkomstige begrippenstelsels hebben immanente begrippen ${ }^{1162}$ nut voor de begripskwalificatie omdat ze de rechter in staat stellen eenzelfde juridische intentie vast te stellen. In de literatuur is dit "Funktionsgleichheit" ge-

1156. Zie VI. \& 3.A.

1157. Zie VI. $\$ 2 . C$ en VI. $\$ 3 . A$.

1158. Zie VI. 3.A.

1159. Zie VI.\$4.A.

1160. Zie VII. $\$ 3$.

1161. Zie VI.\$1.B.

1162. Zie III. 3.B en VI. $\$ 4$.A. 
noemd ${ }^{1633}$ ofschoon er geen sociologisch tertium comparationis aan de orde is zoals bij Zweigert/Kötz ${ }^{164}$. De uitdrukking 'Funktionsgleichheit' is misleidend. Functiebegrippen berusten op een vereenvoudiging van de werkelijkheid ${ }^{1165}$ en ze zijn te glow bal voor het beschrijven van rechtsregels ${ }^{1166}$. Voor de precisering van de definitie van de verwijzingscategorie heeft het functiebegrip van Zweigert/Kötz geen nut, ook al suggereert Esser ${ }^{167}$ het tegendeel. De vorming van immanente begrippen kan mede worden gerechtvaardigd met hun indirecte nut voor de rechtsvergelijkende begripskwalificatie in het IPR.

Voor de kwalificatie van onbekende rechtsinstellingen zoals de ' $m a h r$ ' 1168 hebben comparatieve begrippen geen mut. Verdragen zoals het Haagse Trustverdrag ${ }^{1699}$ bieden hier uitkomst. Waar verdragen ontbreken, is het pleidooi voor de ontwikkeling van gemeenschappelijke rechtsbegrippen op zijn plaats: het desideratum van Rabel ${ }^{170}$ en verwolgens van De Groot, Mincke en Kokkini ${ }^{117}$. Bij het streven van Rabel passen echter twee kanttekeningen. Rabel wil verwijzingscategorieën ontwikkelen voor feitelijke gebeurtenissen zoals het overlijden van een persoon die geen testament nallaat, maar dergelijke 'Lebensverhältnisse' maken een precisering van de definitie van de verwijzingscategorie niet mogelijk ${ }^{1172}$. Bovendien is rechtsvergelijking niet altijd voldoende voor deze precisering ${ }^{1173}$.

De vaagheid van de verwijzingscategorie 1174 kan worden verminderd maar niet worden weggenomen. Het indirecte nut van comparatieve begrippen voor de begripskwalificatie vindt zijn grens waar de vaagheid van de verwijzingscategorie onvoldoende wordt verminderd om een verwijzingsregel toe te passen.

1163. Zie VI 3.A en VI.\$ 4.B.

1164. Zie II. 3.C en III. 2 2.A.

1165. Zute III. 3. A.

1166. Zit III. 2.B en VI. $2 . C$.

1167. Zie VI. $4 . B$.

1168. Zie VI.\$ 1 .B en VI.8 4.B.

1169. Zie VI 3.3.

1170. Zie VI\& $3.1 B$.

1171. Zie II. 2.B.

1172. Zie VI.\$2.A.

1173. Zie VI. 3.B en VI.\$4.B.

1174. Zie VI. $\$ 1 . B$ 


\section{§ 3. Mogelijke studies omtrent comparatieve begrippen}

Een aantal kwesties zijn in deze studie niet of nauwelijks onderzocht. Deze onderwerpen zijn wellicht geschikt voor toekomstige studies omtrent comparatieve begrippen; ze worden hierna summier aangeduid.

Vaagheid van comparatieve begrippen is een beperking die niet is onderkend in de literatuur over het directe nut. Dit probleem doet zich niet alleen voor in het IPR. Vaagheid van comparatieve begrippen is een probleem voor het rechtsvergelijkend onderzoek indien de onderzoeker niet in het midden wil laten welke rechtsregels tot een internationale verzameling ${ }^{1175}$ behoren. Vaagheid van comparatieve begrippen verdient verdere studie.

Een toekomstige studie omtrent comparatieve begrippen kan uitgaan van de vraag waar deze begrippen zijn toegepast in resultaten van rechtsvergelijking. In dit verband kan het onderzoek van Rozmaryn naar de 'rule of law' buiten beschouwing blijven omdat zijn standpunt ten aanzien van comparatieve begrippen onhoudbaar is ${ }^{1176}$. De onderzoeksresultaten van andere auteurs kunnen worden onderzocht op de eventuele hantering van functiebegrippen of immanente begrippen. De vraag is vervolgens of de onderzoekspraktijk laat zien waar comparatieve begrippen zelfstandig bijdragen aan de resultaten die met een rechtsvergelijkende methode bereikt worden.

Ook de jurisprudentie van verschillende rechtsstelsels kan relevant onderzoeksmateriaal opleveren. Uit een analyse van de eventuele motivering van begripskwalificatie in het IPR kan blijken waar verwijzingscategorieën worden verfijnd met comparatieve begrippen. Het is bovendien de vraag in welke gevallen de verwijzingscategorie een typebegrip kan zijn ${ }^{1 ! n}$.

Dat comparatieve begrippen indirect nut hebben voor rechtsvergelijkende thesauri is in het voorafgaande geconstateerd. De volgende linguïstische problemen kunnen nog worden opgelost: hoe zijn woorden herkenbaar als rechtstermen ${ }^{1178}$ ? Doet splitsing

1175. Zie UII. 2.A.

1176. Zie III. 2.A.

1177. Sporadische opmerkingen in de literatuur bieden weinig houwast voor de begripsk wall ficatie. Constantinesco 1974, 317-318, betwiffelt dat typebegrippen wan belang zijn voor het IPR. Zie echter Sandrock. 66: rechtsvergelijking kan op nutrige wijze voorzien in additionele kermerken voor een national typebegrip. Het is in elk geval niet uitgesloten dat kenmerken van en comparatief begrip worden toegevoegd aan een verwijzingscategorie die als een nationaal typebegrip gegeven is.

1178. Zie V.\$3.A. 
van woordsamenstellingen ${ }^{1179}$ daaraan altijd afbreuk? En wat zijn courante rechtstermen die geschikt zijn als descriptoren ${ }^{180}$ ? Het nut van comparatieve begrippen kan worden vergroot door het ontwikkelen wan richtlijnen ${ }^{1181}$ woor de constructie en het actueel houden van rechtsvergelijkende thesauri ${ }^{1182}$, en door het ontwikkelen van speciale computerfaciliteiten voor het zoeken naar documenten ${ }^{1183}$. Daartoe kunnen er experimenten worden uitgevoerd ten aanzien van het zoekgedrag van thesaurusgebruikers; over dit zoekgedrag is nog onvoldoende bekend ${ }^{1184}$. Meer in het bijzonder kan worden onderzocht hoe een rechtsvergelijkende thesaurus geraadpleegd kan worden met behulp van kunstmatige intelligentie of een rechtsvergelijkend expertsysteem ${ }^{1185}$.

Het verdient tenslotte aanbeveling dat een studie wordt verricht naar de algemene hypothese van De Groot ${ }^{1186}$ dat comparatieve begrippen nuttig zijn voor het prepareren van juridische vertalingen. Het fundamentele probleem ${ }^{1187}$ is hier dat de rechtstermen van de doeltaal veelal niet volledig geschikt zijn voor de weergave van de bijzondere intensie van een rechtsbegrip in de brontaal. Het is de vraag of comparatieve begrippen bruikbare criteria zijn voor het op aanvaardbare wijze vertalen van rechtstermen van brontaal naar doeltaal. Comparatieve begrippen zijn wellicht behulpzaam bij de selectie van een in voldoende mate equivalente term in de doeltaal, maar ze kunnen waarschijnlijk niet beslissend zijn voor een geslaagde vertaling van rechtstermen in teksten. De problematiek van de vertaling van juridische teksten mag niet gereduceerd worden tot de problematiek van het vertalen van rechtsbegrippen of rechtstermen ${ }^{1188}$.

1179. Zie V. 3.B.

1180. Zie V. 3.A.

1181. Zie V. 1.A. Internationale samenwerking is hier aan te bevelen; zie het wertkplan wan Kokkin in II. \& 4. B.

1182. De IFLP bevat geen thesaurus: zie V. 4.B. Het verdient aanbeveling dat een rechtsvergehijkende thesaurus bij voorrang voor de IFLP wordt ontwikkeld ondat de IFLP een onovertroffen bibliografie is.

1183. Zie V. $82 . A$.

1184. Weinberg, 41 .

1185. Van der Wes, 119-120. Expertsystemen kunnen omschreven worden als computersystemen voor de oplossing van problemen waarvoor doorgaans menselijke experts worden geraadpleegd.

1186. Zie II. $\$ 2 . B$.

1187. Zie II. 4. A.

1188. Cf. Schòpping/Weyers, 91-93. 
Samenvatting

Dit proefschrift is een studie naar het nut van "comparatieve begrippen". Dit zijn begrippen die in de rechtsvergelijking worden toegepast. Het is onzeker of comparatieve begrippen nuttig zijn. Het staat niet vast dat comparatieve begrippen nuttig zijn in gebieden waarvoor rechtsvergelijking een hulpmiddel is. Dit proefschrift beoogt een fundering, en een precisering van het nut van comparatieve begrippen.

Comparatieve begrippen die onbruikbaar zijn binnen het rechtsvergelijkend onderzoek, zijn a fortiori onbruikbaar in gebieden waarvoor rechtsvergelijking een hulpmiddel is. Daarom is eerst bepaald onder welke voorwaarden comparatieve begrippen nuttig zijn voor drie onderzoeksactiviteiten: het toetsen van een vergelijkbaarheidsoordeel; het beschrijven van overeenkomsten tussen rechtsregels; en het presenteren van voltooid onderzoek. Daarna komen drie verschillende gebieden aan bod waarvoor rechtsvergelijking slechts hulpmiddel is. Deze toepassingsgebieden kunnen aan hun doel beantwoorden zonder het gebruik van comparatieve begrippen. Deze overwegingen bepalen de opbouw van dit proefschrift.

$\mathrm{Na}$ een inleiding (hoofdstuk I) volgt een analyse van de verschillende standpunten ten aanzien van comparatieve begrippen. Dit gebeurt in een literatuurbespreking (hoofdstuk II). Hierin wordt een onderscheid gemaakt tussen het directe nut en het indirecte nut van comparatieve begrippen: het directe nut is gericht op het rechtsvergelijkend onderzoek; het indirecte nut is gericht op toepassingsgebieden buiten dat onderzoek. Eerst wordt een eigen standpunt ontwikkeld ten aanzien van het directe nut (hoofdstuk III) voordat de volgende toepassingsgebieden aan de orde komen: in hoofdstuk $I V$ de rechtsvergelijkende ordeningssystemen; in hoofdstuk $V$ de rechtsvergelijkende thesauri en in hoofdstuk $V I$ de begripskwalificatie in het internationaal privaatrecht. In hoofdstuk VII worden conclusies getrokken uit de voorafgaande hoofdstukken.

De centrale vraag is of comparatieve begrippen direct nut voor het rechtsvergelijkend onderzoek hebben. De analyse van de literatuur (hoofdstuk (I) maakt geen definitief 
antwoord mogelijk. De literatuur laat drie verschillende wijzen van begripsvorming zien: de immanente, de extensionele en de functionele begripsvorming. Immanente begripsvorming vindt plaats door vereenvoudiging van nationale rechtsbegrippen. Bijvoorbeeld: het immanente begrip 'adoptie' bevat uitsluitend de gemeenschappelijke kenmerken van sterke en zwakke adoptie. Extensionele begripsvorming is de opsomming van elementen die in meer rechtsstelsels worden aangetroffen, bijvoorbeeld de gemeenschappelijke elementen van 'rule of law'. De vorming van functiebegrippen is gericht op een sociaal probleem zoals woningnood, waarvoor bijvoorbeeld 'appartementsrecht" een oplossing biedt.

De literatuurbespreking leidt tot de vraag of het rechtsvergelijkend onderzoek is gediend met immanente, extensionele of functionele begrippen. Daarom volgt een bespreking (hoofdstuk III) van de voorwaarden waaronder comparatieve begrippen direct nut hebben. Het uitgangspunt is dat comparatieve begrippen criteria zijn voor de vergelijk baarheid van rechtsregels van verschillende rechtsstelsels. De rechtsregels die vergeleken worden, moeten beantwoorden aan het gemeenschappelijke kenmerk van het comparatieve begrip. Deze intensie bepaalt op welke rechtsregels het comparatieve begrip van toepassing is. Dit geldt niet voor de extensionele begripsvorming van Rozmaryn. Zijn standpunt wordt verworpen. Vergelijkbaarheid is niet gegeven met de rechtsregels waarop een rechtsvergelijkende methode wordt toegepast.

De immanente en de functionele begripsvorming kunnen leiden tot comparatieve begrippen met empirisch nut. Dit nut is afhankelijk van het oordeel dat rechtsregels van verschillende rechtsstelsels vergelijkbaar zijn. Het oordeel dat een comparatief begrip bevat, wordt een vergelijkbaarheidsoordeel genoemd. Dit is een hypothese die getoetst moet kunnen worden aan de vergeleken rechtsstelsels. Deze hypothese kan bijvoorbeeld als volgt geformuleerd worden: vanwege het immanente begrip 'adoptie' zijn de Nederlandse regels van sterke adoptie verge lijkbaar met de Oostenrijkse regels van zwakke adoptie.

De toetsing van het vergelijkbaarheidsoordeel dat immanente begrippen bevat, is athankelijk van de vergeleken begrippenstelsels. Immanente begrippen missen empirisch nut als deze begrippenstelsels te zeer uiteenlopen. De keuze van functiebegrippen lijkt voordelen te bieden omdat dan volledig wordt geabstraheerd van de nationale begrippenstelsels. De functionele begripsvorming van Zweigert/Kötz heeft echter ook nadelen. De toetsing van een vergelijkbaarheidsoordeel dat een functiebegrip bevat, vereist het vaststellen van thet oorzakelijk verband tussen rechtsregels en het oplossen van een sociaal probleem. Het sociale effect van rechtsregels is moeilijk te bepalen zodat het functiebegrip van $Z$ weigert/Kötz meestal geen empirisch nut heeft. 
In hoofdstuk III wordt het directe nut van comparatieve begrippen bepaald voor drie onderzoeksactiviteiten: het toetsen van een vergelijkbaarheidsoordeel; het beschrijven van overeenkomsten tussen rechtsregels; en het presenteren van voltooid onderzoek. Voor de beschrijving van rechtsregels is het functiebegrip van Zweigert/Kötz te globaal. Volgens de literatuur zouden comparatieve begrippen kunnen dienen voor de presentatie van voltooid onderzoek, bijvoorbeeld in de 'International Encyclopedia of Comparative Law". Comparatieve begrippen zijn echter onvoldoende voor de indeling van een rechtsvergelijkend classificatiesysteem in rechtsfamilies. Comparatieve begrippen zijn ook onvoldoende om door middel van een eenduidige terminologie voor de rechtsvergelijking misverstanden omtrent onderzoeksresultaten te voorkomen.

In dit proefschrift wordt de vraag gesteld of comparatieve begrippen nuttig zijn voor drie toepassingsgebieden. Voor de bepaling van dit indirecte nut zijn specifieke maatstaven geformuleerd: de relevantie van de documenten gevonden met een ordeningssysteem of thesaurus; de precisie van de definitie van de verwijzingscategorie aan de hand waarvan de begripskwalificatie in het internationaal privaatreclnt plaatsvindt. Als er onoverkomelijke beperkingen zijn die de toepassing van comparatieve begrippen verhinderen, kan er geen sprake zijn van indirect nut.

Hoofdstuk $I V$ begint met een bespreking van de opbouw van ordeningssystemen voor bibliotheekcollecties. Deze systemen bestaan uit hiërarchische relaties tussen begrippen. Daarna volgt een toelichting op ordeningssystemen voor juridische documenten. Vervolgens wordt ingegaan op rechtsvergelijkende ordeningssystemen. Deze systemen worden ontwikkeld om documenten omtrent een buitenlands rechtsbegrip, bijvoorbeeld het Duitse begrip 'Wohnungseigentum', terug te vinden vanuit het Nederlandse begrip 'appartementsrecht'. Vanwege zijn rechtsvergelijkende momenten krijgt het ordeningssysteem van de Library of Congress bijzondere aandacht. Er wordt geconcludeerd dat comparatieve begrippen een beperkt nut hebben voor rechtsvergelijkende ordeningssystemen. Immanente begrippen verdienen de voorkeur boven de functiebegrippen van Zweigert/Kötz.

In hoofdstuk $V$ worden thesauri in het algemeen en juridische thesauri in het bijzonder geanalyseerd. Thesauri bestaan uit genormaliseerde relaties tussen geselecteerde termen. Dit geldt ook voor rechtsvergelijkende thesauri. De 'Index to Foreign Legal Periodicals' wordt behandeld als een bescheiden aanzet tot een rechtswergelijkende thesaurus. Met rechtsvergelijkende thesauri moeten documenten omtrent een buitenlands rechtsbegrip, bijwoorbeeld 'zwakke adoptie', teruggevonden kunnen worden vanuit de rechtsterm 'sterke adoptie'. Er wordt geconcludeerd dat de functiebegrippen van Zweigert/Kötz geen indirect nut hebben voor rechtsvergelijkende thesauri. 
In hoofdstuk VI wordt de kern van het kwalificatieprobleem gedistilleerd uit de literatuur over dit onderwerp. Er wordt aandacht besteed aan de grondslag en het voorwerp van begripskwalificatie. Het kwalificatieprobleem komt neer op de moeilijkheid dat een kwalificerend begrip moet worden gevormd aan de hand van een verwijzingscategorie. Zonder begripskwalificatie kan niet worden verwezen naar buitenlandse rechtsregels. De verwijzingscategorie, bijvoorbeeld 'familierecht' of 'overeenkomstenrecht', blijkt echter een vaag begrip. De verwijzingscategorie bepaalt niet zelf de kwalificatie wan bijvoorbeeld een verloving. De verwijzingscategorie moet worden verfijnd met toegevoegde kenmerken, bijvoorbeeld 'affectieve relatie'. Er wordt geconcludeerd dat het functiebegrip van Zweigert/Kötz geen nut heeft woor het preciseren van de definitie van een verwijzingscategorie. Immanente begrippen zijn daarentegen bruikbaar voor de rechtsvergelijkende begripskwalificatie in het internationaal privaatrecht.

De conclusies van hoofdstuk VII betreffen het directe nut van comparatieve begrippen voor het rechtsvergelijkende onderzoek en het indirecte nut van comparatieve begrippen voor de drie toepassingsgebieden. De conclusies komen hierop neer dat immanente begrippen over de hele linie nuttiger zijn dan de functiebegrippen van Zweigert/Kötz. De conclusies bevatten tot slot diverse onderwerpen die geschikt lijken voor verdere studie. 
Summary

\section{The Applicability of Comparative Concepts}

This dissertation concerns the applicability of comparative concepts. 'Comparative concepts' are concepts that are applied in comparative law. The question of whether such comparative concepts are of any use has not been answered conclusively. It is disputed whether these concepts can be usefully employed in those areas where comparative law is used as an aid. This dissertation offers a justification for the use of comparative concepts and elaborates on their applicability.

By definition, comparative concepts that are not applicable in comparative studies, are not applicable either in areas in which comparative law functions as an aid. First, therefore, the conditions have been established under which comparative concepts are applicable in three types of research: testing the comparability assumption; describing similarities between legal rules; and presenting research results. Subsequently, three areas are discussed in which comparative law merely serves as an aid. These areas of application may function without the aid of comparative concepts. The above considerations have determined the organization of the dissertation.

The introduction (Chapter $I$ ) is followed by an analysis in Chapter II of the existing ideas on comparative concepts. This is done on the basis of a literature survey. A distinction is made between the direct and indirect applicability of comparative concepts: their usefulness in comparative law (direct) and their usefulness in areas of application outside of comparative studies (indirect). In Chapter III, the author develops his views on the direct usefulness of comparative concepts, after which the following areas of application are discussed: comparative systems of arrangement (Chapter $I V)$, comparative thesauri (Chapter V) and characterization in private international law (Chapter VI). Chapter VII comprises the conclusions drawn from the preceding chapters. 
The core issue of the dissertation is the suitability of comparative concepts for direct use in comparalive legal studies. The analysis of the literature in Chapter I/ fails to yield a conclusive answer. The literature reveals three types of concept formation: immanent, extensional and functional. Formation of immanent concepts occurs as a result of simplifying national legal concepts. An example is the immanent concept of "adoption' which exclusively contains the shared characteristics of 'full' and 'limited' adoption. Formation of extensional concepts is the listing of the elements that can be found in several legal systems, such as the common elements of the 'rule of law.' The formation of functional concepts occurs in relation to social problems, such as housing shortage, to which, for instance, the concept of 'apartment ownership' is a solution.

The literature survey raises the question of whether comparative legal studies benefit from the use of either immanent, extensional or functional concepts. In Chapter III, therefore, the conditions are discussed under which comparative concepts are directly useful. The premise is that comparative concepts are criteria on the basis of which the rules of different legal systems may be compared. The legal rules to be compared must have the characteristics of the comparative concept. This intension determines the applicability of the comparative concept. Rozmaryn's extensional concepts cannot be applied in this way: the author therefore rejects Rozmaryn's view. The legall rules to be compared do not provide their own comparability.

The formation of immanent and functional concepts may result in comparative concepts which are of empirical use. Such use is contingent on the assumption that legal rules from different systems are comparable. An assumption containing a comparative concept is called the comparability assumption. It is a hypothesis which must be tested on the legal systems compared. It can be formulated as follows: because of the immanent concept of 'adoption,' the Dutch rules for 'full adoption' can be compared to the Austrian rules governing 'limited adoption.'

The testing of the comparability assumption containing immanent concepts depends on the conceptual systems that are being compared. Immanent concepts are of no empirical use if these systems are too conceptually divergent. The option of functional concepts seems more advantageous, because with the help of these complete abstraction from national concepts can be achieved. Zweigert and Kötz's functional concepts, however, have their drawbacks. In order to test the comparability assumption containing a functional concept, the causal relation between legal rules and the resolution of a social problem needs to be established. The social effect of legal rules is difficult to determine, however, so that in most cases Zweigert and Kötz's functional concepts have no empirical use. 
In Chapter III, the suitability of comparative concepts for direct use is determined for three types of research: the testing of the comparability assumption; describing similarities between legal rules; and presenting research results. As concepts for describing legal rules, Zweigert and Kötz"s functional concepts are too broad and ill-defined. According to the literature, comparative concepts may be useful in presenting the outcome of an investigation, for instance, in the International Encyclopedia of Comparative Law. Comparative concepts, however, are inadequate for building comparative classification systems dealing with legal families. Comparative concepts are inadequate as unequivocal comparative terminology and therefore cannot serve to eliminate misinterpretation of research results.

In this dissertation, the author examines the usefulness of comparative concepts for three areas of application. Specific criteria have been formulated to facilitate the assessment of such indirect usefulness: the relevance of documents found with the aid of a system of arrangement or with the aid of a thesaurus; and the precision of the definition of the conflict category by which characterization takes place in private international law. If there are insurmountable impediments preventing the application of a comparative concept, there can be no indirect usefulness.

Chapter IV first discusses the building of systems of arrangement for library collections. These systems consist of hierarchical relations between concepts. This is followed by an explanation of systems of arrangement for legal documents. Subsequently, comparative systems of arrangement are discussed. These systems are developed for the purpose of retrieving documents relating to a foreign legal concept, for instance the German concept of "Wohnungseigentum", with the aid of the Dutch legal concept of 'appartementsrecht.' Because of its comparative nature, the classification system of the Library of Congress is given special attention. It is concluded that comparative concepts are of limited use for comparative systems of arrangement. Immanent concepts are to be preferred to Zweigert and Kötz's functional concepts.

Thesauri, in particular legal thesauri, are the subject of Chapter $V$. Thesauri consist of normalized relations between the terms selected. This also holds true for comparative thesauri. The Index to Foreign Legal Periodicals is discussed as a modest step towards a comparative thesaurus. With the aid of comparative thesauri, documents relating to a foreign legal concept, for instance 'limited adoption', may be retrieved by starting from the concept of 'full adoption.' It is concluded that Zweigert and Kötz's functional concepts are of no indirect use for comparative thesauri. 
In Chapter VI, the essence of the characterization problem is distilled from the literature on this subject. Attention is paid to characterization principles and the object of characterization. The essence of the characterization problem is the difficulty in creating a characterizing concept on the basis of a conflict category. Without conceptual characterization, referral to foreign legal rules becomes impossible. The conflict categories 'family law' and 'law of contract' remain vague concepts. They fail to characterize, for instance, "betrothal." The conflict category must be refined by adding characteristics such as 'affective relation.' The author concludes that Zweigert and Kötz's functional concepts are not useful in fine-tuning the definition of a conflict category. Immanent concepts, on the other hand, are useful for the comparative characterization in private international law.

The conclusions drawn in Chapter VII relate to the direct usefulness of comparative concepts for comparative legal studies on the one hand, and their indirect usefulness in three areas of application, on the other. It is concluded that, both for research purposes and in the above areas, immanent concepts are more useful than the functional concepts of Zweigert and Kötz. In this concluding chapter, suggestions are made with regard to subjects deserving of further study.

Translated by L. Rayar B.tr.

Revised by J.D. Gilbert MA 


\section{Glossarium en register}

Dit register is tevens glossarium waarmee voor dit proefschrift belangrijke begrippen toegelicht worden. Het register verwijst naar de paragrafen waarin begrippen of personen behandeld zijn. Er wordt niet verwezen naar voetnoten.

Aanknopingsfactor

$\rightarrow \quad$ VI. $\$ 1 . A$, VI. $\$ 1 . B$

Adoptie

$\rightarrow \quad$ II, III. $\$ 2 . B$, III.\$3.A, V.§ 4.B, VII. \& 2.B

Appartementsrecht

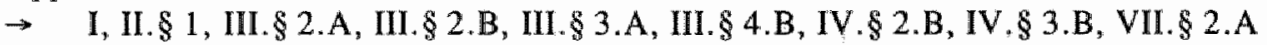
Assimilatie

$\rightarrow \quad$ IV.\&3.C

Begriffsjurisprudenz

$\rightarrow \quad$ II. \$3.C

Begrip

beschrijvend

$\rightarrow$ II. \& 4.A, III.\$2.B

comparatief (criterium voor de vergelijkbaarheid wan rechtsregels van verschillende rechtsstelsels)

$\rightarrow$ I, II. $\$ 1$, II. $\$ 2 . A$, II. \& 3.C, II. \& 5, III.\& 1, III.\& 2.A, III.\& 2.B, III.\& 3.A, III.\& 5.A, III.\& 5.B, VII.\& 1.A, VII.\$ 1.B, VII.\& 2.C, VII.\$ 3

immanent (comparatief begrip met minder kenmerken dan nationale rechtsbegrippen)

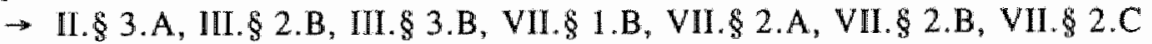


inhoud

$\rightarrow$ Intensie

intuittief

$\rightarrow$ III.\$ 2.A, VII.\& 1.A

normatief

$\rightarrow$ II. $\$ 4 . A$, III. $2 . B$

omvang

$\rightarrow$ Extensie

universeel

$\rightarrow$ II.\$2.A, II.\& 3.C, II.\& 4.A, II. 4.B, III.§ 3.A, VI.\$ 3.B

vaag

$\rightarrow$ II. $\$ 1$, VI.\& $1 . B$, VII.\& $2 . C$

vorm

$\rightarrow$ II.\& 1, II.\$ 3.A, II.\$ 3.B, II.\$ 3.C, III.\& 3.B, III.\& 5.B

Begrippenstelsel (systematisch geheel van begrippen)

$\rightarrow \quad$ II. \$ 3.C, II.\$ 4.A, III.\& 2.B, III. \$ 3.B, VI. \$ 4.A, VII.\$ 1.B, VII. \& $2 . \mathrm{C}$

Begripsidentiteit (gemeenschappelijke kenmerken)

$\rightarrow \quad$ III. \& 4.B, V.\& 4.C, VII.\$2.B, VII.\$ 3

Begripsindeling (indeling van een begrippenstelsel)

$\rightarrow \quad$ II. $\$ 4 . A, I V . \& 1 . A, V I . \S 4 . A$

Begripskenmerk (voorwaarde voor de toepassing van een begrip op een object)

$\rightarrow \quad$ II. $\$ 1$, IV.\$ 1.A

Begripskwalificatie (begripsverfining voor de aanwijzing van het toepasselijke rechtsstelsel)

$\rightarrow \quad$ II. $\$ 2 . B$, VI. $\$ 1 . B, V I I . \S 2 . C$, VII. $\$ 3$

grondslag

$\rightarrow$ VI.\&3.A, VI.\$3.B

secundair

$\rightarrow$ VI. $\$ 1 . B$

verdragsautonoom

$\rightarrow \mathrm{VI} . \S 3 . \mathrm{B}$

voorwerp

$\rightarrow$ VI.\& 2.A, VI.\$2.B, VI.\$2.C

Begripsrepresentatie (weergave van een begrip)

$\rightarrow \quad$ II. $\$ 4 . A$, II. $\$ 4 . B$, III.\$ 4.B, V. $\$ 1 . A$

Begripsvereenvoudiging (begripsworming door het weglaten wan begripskenmerken)

$\rightarrow \quad$ II. $\$ 3 . A$, III.\& 3.B

Begripsverfijning (begripsvorming door het toevoegen van begripskenmerken)

$\rightarrow \quad$ III. $\$ 2 . \mathrm{B}$, III. $\$ 5 . \mathrm{B}, \mathrm{VII} . \$ 2 . \mathrm{C}$ 
Beschrijving (van rechtsregels)

$\rightarrow \quad$ II. \$ 2.A, II.\$ 4.A, III. 2.B, III.\$ 4.A, VI. \$ 4.A.VII.\$ 1.B, VIII. $2 . C$ Bibliotheekcollectie

$\rightarrow \quad$ II.§ 2.B, IV.§ 3.A, IV.§ 3.C. IV.\$ 5.A

Civil law

$\rightarrow \quad$ IV. \$ 3.C, IV.\$ 5.A, IV.\$ 5.B, IV.\$ 5.C, VI.\$4.A, VII.\$2.A

Classificatiebegrip (soortbegrip in een ordeningssysteem)

$\rightarrow \quad$ IV. $\$ 1 . A, I V . \S 2$.A

rechtsvergelijkend (classificatiebegrip met kenmerken gemeenschappelijk aan verschillende rechtsstelsels)

$\rightarrow$ IV.\$ 3.A, IV.\$ 3.B, IV.\$ 5.B, IV.\$ 5.C, VII.\& 2.A

Common law

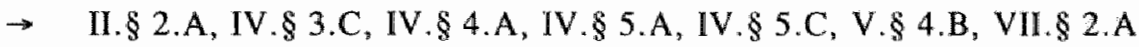

Constantinesco

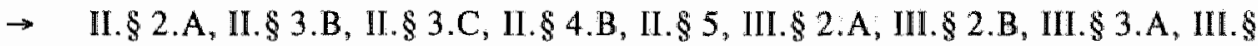
3.B, III.\&4.A, VII.\$1.A, VII.\$1.B

Definitie

$\rightarrow \quad$ II. $\$ 1$, III.§ 2.A, III.\& 5.B IV. \$ 5.A, V.\$3.A, VI.\$ 1.B

Descriptor (woord geselecteerd voor een thesaurus)

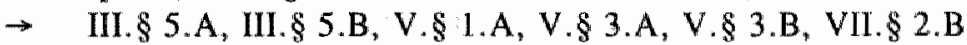

Document (tekst zoals boek of tijdschriftartikel)

$\rightarrow \quad$ IV.\$2.A, V.\$1.A, V.\$2.B, V. \&3.A

Dogmatiek

$\rightarrow$ Begrippenstelsel

Drobnig

$\rightarrow \quad$ II.\$ 2.A, II.\$4.B, III.\$2.B, III.\$3.A, III.\$4.A, III.\$4.B, VII.\& 1.A, VII.\& 1.B

Ellinger

$\rightarrow \quad$ IV.\$3.A, IV.\$3.C. IV.\$4.C

Eltzbacher

$\rightarrow \quad$ II. \& 3.A, II. \& 4.B, III.\& 4.A, VII.\& I.A, VII. \& 1.B

Engisch

$\rightarrow \quad$ II. $\$ 2 . A$, III. \&2.B, III.\$4.A

Erfdeel

$\rightarrow \quad$ III. $\$ 2 . B_{0}$ III. $\$ 4 . B, V . \$ 4 . A, V . \S 4 . B, V I I . \$ 2 . B$

Esser

$\rightarrow \quad$ VI.\& 4.B, VII.\& 2.C 
Extensie (verzameling wan objecten met eigenschappen die overeenkomen met de intensie)

$\rightarrow \quad$ II. $\$ 1$

Extensionele begripsvorming (selectie van gemeenschappelijke elementen)

$\rightarrow \quad$ II. \& 3.B, III.\$2.A, IV.\& 3.C, VII. \& 1.B

Functiebegrip (comparatief begrip zonder kenmerken van nationale rechtsbegrippen)

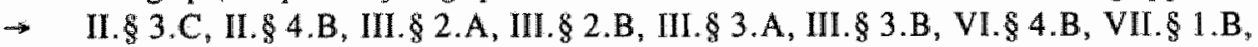
VII.\$ 2.A, VII.\& 2.B, VII.\$2.C

Goederenrecht

$\rightarrow \quad$ II.\& 4.A, III.\$2.B, III.\$ 3.B, III.\& 4.A, VI.\$ 4.A, VII.\$1.B

Goldberg

$\rightarrow \quad$ IV.\$5.B

de Groot

$\rightarrow \quad$ II. $\$ 2 . B$, III. \& 5.A, VII.\&2.B, VII. \& 2.C, VII. 3

Hall

$\rightarrow \quad$ II. \& 3.B

Hiërarchie (relatie tussen lagere en hogere begrippen)

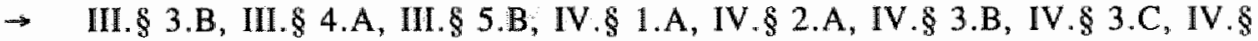

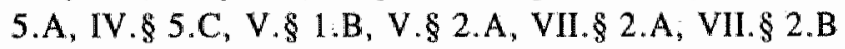

Huwelijksgeld

$\rightarrow \quad$ VI.\& 4.A, VI.\& 4.B, VII. \& 2.C

Hypotheek

$\rightarrow \quad$ III.\$2.B, III.\$3.B, IV.\$2.A, IV.\$3.B, IV.\$ 5.C, VI.\$ 4.A

IFLP

$\rightarrow \quad$ Index to Foreign Legal Periodicals

Indelingskarakteristiek (criterium voor de specificatie van een soortbegrip)

$\rightarrow \quad$ IV.\& 1.B. IV.\$3.A

Index to Foreign Legal Periodicals

$\rightarrow \quad$ V.\$4.B. V.\$4.C

Intensie (éên of meer begripskenmerken)

$\rightarrow \quad \mathbb{1 1 . \$ 1}$

Intentie

$\rightarrow \quad$ Juridische intentie 
Internationaal privaatrecht (recht omtrent de samenloop van nationale rechtsstelsels bij grensoverschrijdende privaatrechtelijke rechtsverhoudingen)

$\rightarrow \quad$ VI. $\$ 1 . \mathrm{A}$

Internationale verzameling (verzameling van rechtsregels die tot verschillende rechtsstelsels behoren)

$\rightarrow \quad$ III. $\$ 2 . \mathrm{A}$, III. $\$ 2 . \mathrm{B}$

Internationall Encyclopedia of Comparative Law

$\rightarrow \quad$ II. $\$ 2 . A$, II. $\$ 4 . B$, III. $\$ 4 . A$

Interpretatie

$\rightarrow \quad$ III. \&3.B, IV.§ 2.A, VI.\& 1.B

IPR

$\rightarrow \quad$ Internationaal privaatrecht

Islamitisch recht

$\rightarrow \quad$ IV.\&4.A, VI. $\$ 4 . B$

Juridische intentie

$\rightarrow \quad$ I, III. $\$ 2 . B$, III.\& 3.B, III. 4 4.B, VII.§ $1 . B$, VII. $\$ 2 . \mathrm{C}$

Klasse (extensie vam een soortbegrip)

$\rightarrow \quad$ IV.\& 1.A, IV.\& 3.C

Klasseren

$\rightarrow \quad$ IV.\$ 2.A

Knapp

$\rightarrow \quad$ V.§ 4.A

Kötz

$\rightarrow \quad$ Zweigert/Kötz

Kokkini

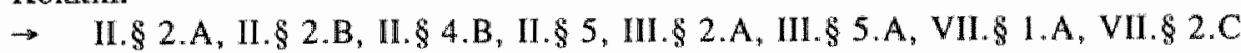

Korevaar

$\rightarrow \quad$ IV.\$4.A

Kosters

$\rightarrow \quad$ VI.\& 3.A

Kreuzer

$\rightarrow \quad$ IV.\$ 4.C, VII.\& 2.A

Kwalificatie

$\rightarrow \quad$ Begripskwalificatie

Lansky

$\rightarrow \quad$ IV.\$3.A, IV.\$ $4 . B$ 
$\mathrm{LCC}$

$\rightarrow \quad$ Library of Congress Classification

Lex fori (rechtsstelsel met de verwijzingscategorie)

$\rightarrow \quad$ VI.\& 3.A, VI.\& 3.B, VI.\& 4.A, VI.\& 4.B, VII.\& 2.C

Library of Congress Classification

$\rightarrow \quad$ IV.\$3.A.IV.\& 5.A, IV.\& 5.B, IV.\$5.C, VII.\& 2.A

Mahr

$\rightarrow$ Huwelijksgeld

Metataal (taal waarmee een aitspraak over een rechtstaal gedaan kan worden)

$\rightarrow \quad$ II.\& 1, II.\&2.B, II.\&4.A

Mincke

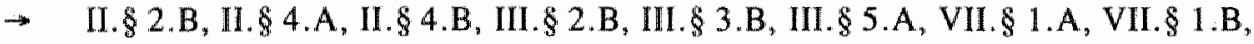
VII. $\$ 2 . \mathrm{C}$

Model (vereenvoudigde voorstelling van zaken)

$\rightarrow \quad$ III. $\$ 3 . A$

Modelclassificatie (rechtsvergelijkend ordeningssysteem dat berust op vereenvoudigende veronderstellingen)

$\rightarrow \quad$ IV.\$5.A, IV.\$5.B, IV.\$ 5.C, VII.\& 2.A

Moys

$\rightarrow \quad$ IV.\$3.A, IV.\$4.A, IV.§4.B, VII. \$2.A

Nagy

$\rightarrow \quad$ IV. $\$ 4$.A

Nevenschikking

$\rightarrow \quad$ IV.\& 2.C, V.\& 1.A, VII.\& 2.B

Non-descriptor

$\rightarrow \quad$ V.\$ 1.A. V. \$ 4.A

Notatie (cijfers en/of letters)

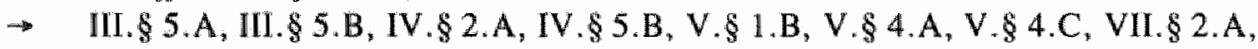
VII. $\$ 2 . B$

Nut

direct (bijdrage aan het verkrijgen, beschrijven of presenteren van resultaten van rechisvergelijkend onderzoek)

$\rightarrow$ I, II. \& 2.A, III.\$1, VII.\$1.A, VII.\$1.B

empirisch (bijdrage van een comparatief begrip dat een internationale verzameling omvar)

$\rightarrow$ III.\$ 1, III. $\$ 2 . A$, III. $\$ 3 . A$, III. \$ 3.B, VII. $\$ 1 . B$

heuristisch (bijdrage aan een zoekproces) 
$\rightarrow$ II. $\$ 2 . A$, III. $\$ 3 . \mathrm{A}$

indirect (bijdrage aan toepassingsgebieden buten het rechtsvergelijkend onderzoek)

$\rightarrow$ I, II. $\$ 2 . A$, II. $\$ 2 . B$, III.\$ 1, III. \$ 5.A, III.\$ 5.B, VII.\$2.A, VII. $\$ 2 . B, V I I . \$$ 2.C

Omgangstaal

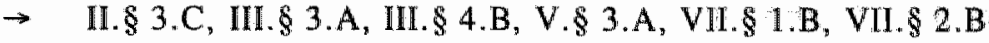

Onderzoek

$\rightarrow \quad$ Rechtswergelijkend onderzoek

Ongerechtvaardigde verrijking

$\rightarrow \quad$ I, II. $\$ 4 . A$, II. $\$ 4 . B$, III. \$ 4.B

Opbrengst (verhouding tussen feitelijk gevonden en alle relevante documenten)

$\rightarrow \quad$ V.\$2.B

Operator $(E N, O F)$

$\rightarrow \quad$ V.\$2.A, V. \$2.B, V.\$3.B

Opvolgingskarakteristiek (criterium voor de volgorde van nevengeschikte classificatiebegrippen)

$\rightarrow \quad$ IV.\$2.C, IV.\$3.A

Ordeningssysteem (hiërarchisch systeem van soortbegrippen en meer specifieke begrippen)

$\rightarrow \quad$ IV.§ 1.A, V. $\S 1 . \mathrm{B}$

rechtswergelijkend (ordeningssysteem voor het terugvinden van documenten omtrent een buitenlands rechtsstelsel)

$\rightarrow$ II. $\$ 2 . B$, IV.\$ 3.A, VII. \&2.A

Polyhiërarchie

$\rightarrow \quad$ IV. $\$ 2 . B$, V. $\$ 1 . B$, VII. $\$ 2 . A$

Postcoördinatie

$\rightarrow \quad$ V.\$3.B, V.\$4.A

Precisie (verhouding tussen relevante en irrelevante deelverzameling van de vangst)

$\rightarrow \quad$ V.\$2.B, V.\$3.B, V.\$4.A, V.\$ 4.C, VII. 2.A, VII.\$2.B

Quasi-synoniem (termen die geacht worden hetzelfde begrip weer te geven)

$\rightarrow \quad$ V.§ 1.A, V.\&4.A, V.\&4.C, VII.\& 2.B

Rabel

$\rightarrow \quad$ II. $\$ 2 . \mathrm{B}, \mathrm{VI} . \$ 2 . \mathrm{A}, \mathrm{VI} . \S 2 . \mathrm{B}, \mathrm{VI} . \S 3 . \mathrm{B}, \mathrm{VII} . \S 2 . \mathrm{C}$

Rechtsbegrip (begrip van een rechtsstelsel dat verwijst naar rechtsregels)

$\rightarrow \quad$ I, II. 3 3.C, II.\$ 4.A, II.\$ 4.B, IV.\$2.A, VI.\& 2.A, VII. \&2.A 
Rechtsfamilie (groep van rechtsstelsels)

$\rightarrow \quad$ II. 2.A, II. 3.A, II. 4.B, III.8 4.A, III.\$ 5.A, IV.\&3.C, IV. \$4.A

Rechtsgebied

$\rightarrow \quad$ II. 2.A, III.\& 3.B, IV.\& 2.B, IV.\& 2.C. IV.\& 3.C, IV.\& 4.C

Rechtsgevolg

$\rightarrow \quad J u r i d i s c h e$ intentie

Rechtsinstelling (complex van rechisregels ter realisering van een maatschappelijk doel)

$\rightarrow \quad$ II. $\$ 1, I I . \$ 3 . B, V I . \$ 4 . B$

Rechtsnorm

$\rightarrow$ Rechtsregel

Rechtsorde

$\rightarrow$ Rechtsstelsel

Rechtsregel (algemeen voorschrift dat behoort tot een rechtsstelsel)

$\rightarrow \quad$ IV.\&2.A, VI.\& 2.C

materieel

$\rightarrow$ VI.\&1.A, VI.\& 1.B, VI.\$2.B, VI.\& 2.C

Rechtsstelsel (begrippenstelsel met rechtsregels die gelden voor een nationale samenleving)

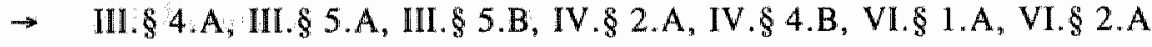
meertalig

$\rightarrow$ V.\&4.C

Rechtssysteem

$\rightarrow \quad$ Rechtsstelsel

Rechtstaal (taal gebruikt door een rechtsstelsel)

$\rightarrow \quad$ I, III. $\$ 4 . B$, V. $\$ 4 . C$

Rechtsterm

$\rightarrow$ Term

Rechtsvergelijkend classificatiesysteem (systematisch geheel van comparatieve begrippen)

$\rightarrow \quad$ II. $\$ 2 . A$, II. \$ 4.B, III.\$ 4.A, III.\$ 5.A, VII.\$1.A, VII. \$1.B

Rechtsvergelijkende methode

$\rightarrow \quad$ II.\$ 2.A. III.\$ 1, III.\& 2.A

Rechtsvergelijkend onderzoek (onderzoek naar overeenkomsten en verschillen met betrekking tot rechtsstelsels of onderdelen daarvan)

$\rightarrow \quad$ I, II. \& 1, III.\$ 5.A, VI. \& 3.B

beginfase

$\rightarrow$ II. $\$ 2 . A$, II.\$ 3.C, II. \$ 4.B, III.\$2.A, VII.\$ 1.A

eindfase

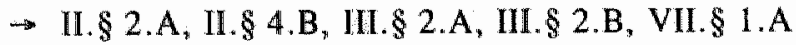


Rigaux

$\rightarrow \quad$ VI.§ $2 . \mathrm{A}$

Rozmaryn

$\rightarrow \quad$ II.\$3.B, II. 4 $4 . B$, III.\$2.A, VII.\$ 1.A, VII.\$1.B, VII. $\$ 3$

Rubrieksomschrijving

$\rightarrow \quad$ IV. $\$ 2 . A$

Rule of law

$\rightarrow \quad$ I, II. $\$ 2 . A$, II. $\$ 3 . B$, III. $\$ 2 . A, V . \$ 4 . B$, VII. $\$ 3$

Sacco

$\rightarrow \quad$ II. 3.A, VII. \& I.A

Schiller

$\rightarrow \quad$ IV. \& 3.A, IV.\$3.B, IV.\$3.C, VII.\& 2.A

Socialistisch recht

$\rightarrow \quad$ II. $\$ 3 . C, I V . \$ 4 . A$, IV.\$ 5.A, IV.\$ 5.B, V.\$4.B

Soortbegrip (begrip met werbonden kenmerken)

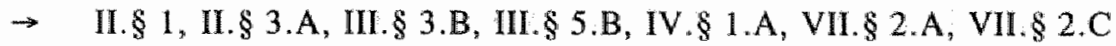

Specificatie

$\rightarrow \quad$ III. \$ 3.B, IV.\$ 1.A, IV.\& 4.C, V.\& 2.B

Steiner

$\rightarrow \quad$ IV.\$ 3.A, IV.\$ 4.A. IV.\$ 4.B, IV.\$ 4.C, V.\$ 4.B, V.\$ 4.C, VII.\$ 2.A

Synoniem (term die hetzelfde begrip weergeeft)

$\rightarrow \quad$ III. $\$ 4 . B, V . \S 1 . A, V . \S 3 . A$, V. $\$ 4 . A, V . \S 4 . C, V I I . \S 1 . B, V I I .2 . B$

Term

$\rightarrow \quad$ I, V.\$3.A

eenduidig

$\rightarrow$ Synoniem

elementair (weergave van zuiver gemeenschappelijke rechtsbegrippen)

$\rightarrow$ II. $\$ 4 . A$, III.\$ 4.B, VII.\$2.B

generiek

$\rightarrow$ IV. \&4.C, V.\& 4.B, V.\$ 4.C

meerduidig (weergave van verschillende rechisbegrippen)

$\rightarrow$ III.\& 4.B, V. \& 3.A, VII.\& 1.B, VII. \& 2.B

Tertium comparationis

$\rightarrow$ Begrip, comparatief

Thesaurus (descriptoren vastgelegd met genormaliseerde relaties)

$\rightarrow \quad$ V.\$1.A

meertalig (thesaurus met descriptoren uit verschillende talen) 
meertalig (thesaurus met descriptoren uit verschillende talen)

$\rightarrow$ II.\& 2.B, V.8 4.A, VII.\& 2.B

rechtsvergelijkend (thesaurus voor het terugvinden van documenten omtrent een buitenlands rechtsstelsel)

$\rightarrow$ II. $\$ 2 . B$, II. \& 4.B, V.\& 4.A, V.\&4.C, VII. \& 2.B, VII. 33

Trust

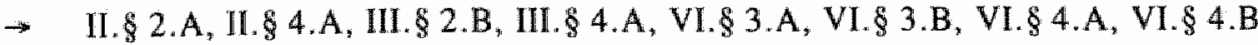
Typebegrip (begrip met kenmerken in disjunctieve verhouding)

$\rightarrow \quad$ II. \& 1, III.\$2.A, III. \& 2.B, III.\& 3.B, VII. \& 2.C, VII. \& 3

Universele Decimale Classificatie

$\rightarrow \quad$ IV.\$4.A, IV.\$5.A

Vaststellingsovereenkomst

$\rightarrow \quad$ III.\& 2.A, IV.\$3.B

Vergelijkbaarheidsoordeel (hypothese die een comparatief begrip bevat)

$\rightarrow \quad$ II. \$ 1, III.\& 1, III.\& 2.A, III.\& 2.B, III.\& 3.A, III.\&3.B, VII.\$1.A

Vergelijkingsbasis

$\rightarrow$ Begrip, comparatief

Verloving

$\rightarrow \quad$ I, III.\$ 5.B, VI.\$ 1.B, VI.\& 2.B

Vertalen

$\rightarrow \quad$ I, II. $\$ 2 . B$, II.\$ 4.A, II.\& 4.B, III. \& 4.B, V.\$ 4.A, V. \$ 4.B, VII. 33

Verwijzingscategorie (toepassingsvoorwaarde voor de rechtsregels van het rechisstelsel dat moet gelden]

$\rightarrow \quad$ VI.\$1.A, VI.\$ 1.B, VI.\& 2.C, VII.\& 2.C

Verwijzingsregel

$\rightarrow$ VI.\$ 1.A. VI.\$ 1.B, VI.\$ 2.B, VI.\$2.C, VII.\$2.C

de Wild

$\rightarrow \quad$ II.\$2.B, VII. \$2.B

Woordenboek

$\rightarrow \quad$ V.\$4.A

Woordgroep

$\rightarrow \quad$ V.\$4.B, VII. $\$ 2 . B$

Woordsamenstelling

$\rightarrow \quad$ V.\$3.B, V.\& 4.A, VII.\$2.B, VII. \$3 


\section{Zweigert/Kötz}

$\rightarrow \quad$ I, II. 2.A, II. 2.B, II. 3.C, II. \$ 4.B, II. \$ 5, III. \$ 2.A, III. \& 2.B, III.\$ 3.A, III.\$3.B, III.\$ 4.A, III.\$4.B, VII.\$ 1.A, VII.\$ 1.B, VII.\$2.A, VII.\$2.B, VII. $\$ 2 . C$ 


\section{Geciteerde literatuur}

Aitchison/Gilchrist J. Aitchison, A. Gilchrist, Thesaurus construction, second edition, London, 1987.

Alchourrón/Bulygin C.E. Alchourrón, E. Bulygin, Normative Systems, Wien/New York, 1971.

Allarousse $\quad$ V. Allarousse, A Comparative Approach to the Conflict of Characterization in Private International Law, Case Western Reserve journal of international law 1991, 479-516.

Altamira R. Altamira, Suggestions pour un plan de travail en vue de rédiger un vocabulaire juridique comparé des langues allemande, anglaise, espagnole, française et italienne, Actorum Academiae Universalis Jurisprudentiae Comparativae Vol. II Pars 1, 1934, 237-239.

Ancel B. Ancel, L'objet de la qualification, Journal du droit international 1980, 227-268.

Anders

M. Anders, Probleme der Erarbeitung des mehrsprachigen Thesaurus Staat und Recht des SGI, Informatik 1986, 54-57, 80; 94-98.

Angell

R.S. Angell, Development of Class $\mathrm{K}$ at the Library of Congress, Law Library Journal 1964, 353-360. 
Arminjon/Nolde/

Wolff

Aubert

Audit 1991

Audit 1993

Austin

von Bar

Barberis

Bartels

Batiffol/Lagarde

Bauer 1973

Bauer 1982
P. Arminjon, B. Nolde, M. Wolff, Traité de droit comparé, Tome I, Paris, 1950.

V. Aubert, Proeven van rechtssociologie uit het werk van Vilhelm Aubert, B. Peper en C.J.M. Schuyt (red.), Rotterdam/Antwerpen, 1971.

B. Audit, Droit international privé, Paris, 1991.

B. Audit, Qualification et droit international privé, Droits 1993, $55-65$.

D. Austin, Progress towards standard guidelines for the construction of multilingual thesauri, in: Third European Congress on Information Systems and Networks, Volume 1, München 1977, 341-351.

C. von Bar, Internationales Privatrecht, Band 1: Allgemeine Lehren, München, 1987.

M. Barberis, Universal Legal Concepts? A Criticism of "General" Legal Theory, Ratio Juris 1996, 1-14.

H.-J. Bartels, Methode und Gegenstand intersystemarer Rechtsvergleichung, Tübingen, 1982.

H. Batiffol, P. Lagarde, Traité de droit international privë, Tome 1, 8e édition, Paris, 1993.

H. Bauer-Bernet, Rechtsdokumentation, Frankfurt am Main, 1973.

H. Bauer-Bernet, Legal thesauri and data processing, in: A. Martino, Deontic Logic, Computational Linguistics and Legal Information Systems, Volume II, Amsterdam/New York/Oxford $1982,237-266$. 
Baurnann

Beckett

Bell

Bellert/Wojtasiewicz I. Bellert, O.A. Wojtasiewicz, On a definition of a thesaurus system and thesaurus structures, in: International scientific symposium on multilingual thesauri, Berlin 1973, 154-157.

van den Bergh

Bergmann/Ferid

Bertels/Nauta

Birch

de Boer 1992

de Boer 1994

van Boeschoten 1993 C.D. van Boeschoten, Rechtsbegrippen in verdragen van de Haagse Conferentie voor internationaal privaatrecht en thet Nederlandse recht, Rechtsgeleerd magazijn Themis 1993, 211-222. 
van Boeschoten 1994 C.D. van Boeschoten, Het Halagse Trustverdrag in Nederlands perspectief, preadvies, Lelystad, 1994.

de Boom/etc.

W.H. de Boom, S. Eelman, H.A. Enting, R. Poede, M.H. ten Wolde, Het toepasselijke recht op ongehuwd samenwonenden. Een aanvulling op de "Schets van een algemene wet betreffende het internationaal privaatrecht"?!, Rechtsgeleerd magazijn Themis 1992, 452-463.

Borman

T.C. Borman, Aanwijzingen voor de regelgeving, Den Haag, 1993.

van Brakel

S. van Brakel, Grondslagen en Beginselen van Nederlands Internationaal Privaatrecht, derde druk, Zwolle, 1953.

Broadfield

Broadfield, The philosophy of classification, London, 1946.

Brouwer

P.W. Brouwer, Samenhang in recht, diss., Groningen, 1990.

Buchanan

B. Buchanan, Theory of library classification, London/Munich/New York/Paris, 1979.

Butler 1985

W.E. Butler, Comparative Approaches to Internationall Law, Recueil des cours de l'Académie de Droit International 1985, 9-89.

Butler 1992

W.E. Butler, Comparative law and international law, in: R. Bernhardt, Encyclopedia of Public International Law, Volume I, Amsterdam/London/New York/Tokyo 1992, 699-702.

Canaris

C.-W. Canaris, Systemdenken und Systembegriff in der Jurisprudenz, 2. überarbeitete Auflage, Berlin, 1983.

Chan

L.M. Chan, Immroth's guide to the Library of Congress classification, fourth edition, Englewood, 1990.

Coene/Geelhand M. Coene, N. Geelhand, De legitieme portie in rechtsvergelijkend perspectief, in: De legitieme portie. 30e Landelijk notarieel studentencongres, Deventer 1995, 19-36. 
Cohen Henriquez

1980

E. Cohen Henriquez, I.P.R. trends, Deventer, 1980.

Cohen Henriquez

1986

E. Cohen Henriquez, Trusts (II). Internationaal privaatrechtelijke aspecten, Maandblad voor ondernemingsrecht en rechtspersonen (TVVS) $1986,270-274$.

Coing

H. Coing, Geschichte und Bedeutung des Systemgedankens in der Rechtswissenschaft, in: $\boldsymbol{H}$. Coing, Zur Geschichte des Privatrechtsystems, Frankfurt am Main 1962, 9-28.

Collier

J.G. Collier, Conflict of laws, second edition, Cambridge, 1994.

Collins

L. Collins, Dicey and Morris on the conflict of laws, Volume 2, twelfth edition, London, 1993.

Constantinesco 1972a L.-J. Constantinesco, Rechtsvergleichung, Band II: Die rechtsvergleichende Methode, Köln/Berlin/Bonn/München, 1972.

Constantinesco 1972b L.-J. Constantinesco, Traité de droit comparé, Tome I: Introduction au droit comparé, Paris, 1972.

Constantinesco 1974 L.-J. Constantinesco, Traité de droit comparé, Tome II: La méthode comparative, Paris, 1974.

Constantinesco 1981 L.-J. Constantinesco, Der Rechtsbegrilf in der Makro-Vergleichung, Zeitschrift für vergleichende Rechtswissenschaft 1981, 177-198.

Constantinesco 1983 L.-J. Constantinesco, Traité de droit comparé, Tome III: La science des droits comparés, Paris, 1983.

Corbett

M. Corbett, Indexing and Searching in Statutory Text, Law Library Journal 1992, 759-767.

Dabney

D.P. Dabney, The Curse of Thamus. An Analysis of Full-Text Legal Document Retrieval, Law Library Journal 1986, 5-40. 
Dahlberg 1974

Dahlberg 1981a

Dahlberg $1981 \mathrm{~b}$

Daly

David 1960

David 1980

David 1992

Didier

Dobrowolski

Dörner

Douven

Drobnig 1966

Drobnig 1969
I. Dahlberg, Grundlagen universaler Wissensordnung, Pullach bei München, 1974.

I. Dahlberg, Conceptual Definitions for INTERCONCEPT, International Classification 1981, 16-22.

I. Dahlberg, Towards Establishment of Compatibility Between Indexing Languages, International Classification 1981, 86-91.

G.M. Daly, Reference Work in a Classified Collection. Is LC Class K Successful? Legal Reference Services Quarterly 1993, 91-104.

R. David, Review. Index to Foreign Legal Periodicals, Law Library Journal 1960, 234-235.

R. David, English law and French law, London/Calcutta, 1980.

R. David, Les grands systèmes de droit contemporains, 10e ếdition, Paris, 1992.

E. Didier, Langues et langages du droit, Montréal, 1990.

Z. Dobrowolski, Étude sur la construction des systèmes de classification, Paris/Warszawa, 1964.

H. Dörner, Qualifikation im IPR - ein Buch mit sieben Siegeln?, Das Standesamt 1988, 345-352.

1. Douven, Intern realisme en incommensurabiliteit, Algemeen Nederlands Tijdschrift voor Wijsbegeerte 1995, 142-164.

U. Drobnig, L'encyclopédie internationale de droit comparé, Revue internationale de droit comparé 1966, 138-141.

U. Drobnig, Methodenfragen der Rechtsvergleichung im Lichte der "International Encyclopedia of Comparative Law", in: $\mathbf{E}$. von Caemmerer, S. Mentschikoff, K. Zweigert, Ius Privatum 
Drobnig 1972

Drobnig 1977

Drobnig 1986

Eckhoff/Sundby

Eisenmann

Eisenstadt

Ellinger 1949

Ellinger 1956

Ellinger 1962

Ellinger 1964
Gentium. Festschrift für Max Rheinstein, Band I: Rechtsmethodik und internationales Recht, Tübingen 1969, 221-233.

U. Drobnig, The international encyclopedia of comparative law. Efforts toward a worldwide comparison of law, Cornell internationall law joumal $1972,113-129$.

U. Drobnig, Rechtsvergleichung und Rechtssoziologie, in: U. Drobnig, M. Rehbinder, Rechtssoziologie und Rechtsvergleichung, Berlin 1977, 20-34.

U. Drobnig, Möglichkeiten und Grenzen intersystemarer Rechtsvergleichung auf dem Gebiet des Zivilrechts, in: G. Gutmann, S. Mampel, Probleme systemvergleichender Betrachtung, Berlin 1986, 195-205.

T. Eckhoff, N.K. Sundby, Rechtssysteme, Berlin, 1988.

C. Eisenmann, Quelques problèmes de mëthodologie des définitions et des classifications en science juridique, Archives de phillosophie du droit 1966, 25-43.

S.N. Eisenstadt, Social Institutions. The Concept, in: D.L. Sills, International Encyclopedia of the Social Sciences, Volume 13, New York/London 1968, 409-421.

W.B. Ellinger, Subject Classification of Law "The Library Quarterly $1949,79-104$.

W.B. Ellinger, Adress on the development of Class K, Law Library Journal $1956,453-457$.

W.B. Ellinger, Basic Problems of Cataloging and Classifying Foreign Legal Materials, Law Library Journal 1962, 377-385.

W.B. Ellinger, Some Observations on Classification Theory in the Development of Class K, Law Library Journal 1964, 360-366. 
Ellinger 1968

Eltzbacher

Engelien

Engisch 1957

Engisch 1958

Engisch 1968

Engisch 1973

Esser

Europees Parlement

Evans

M.M. Evans, A History of the Development of Classification K (Law) at the Library of Congress, Law Library Journal 1969, 25-39.

Ferid/Firsching

Fikentscher

W.B. Ellinger, Classification of Law at the Library of Congress. 1949-1968, Law Library Journal 1968, 224-236.

P. Eltzbacher, Über Rechtsbegriffe, Berlin, 1900.

G. Engelien, Der Begriff der Klassifikation, Hamburg, 1971.

K. Engisch, Sinn und Tragweite juristischer Systematik, Studium Generale 1957, 173-1.90.

K. Engisch, Die Relativität der Rechtsbegriffe, in: M. Ferid, Deutsche Landesreferate zum V. Internationalen Kongre/3 für Rechtsvergleichung in Brüssel 1958, Berlin 1958, 59-75.

K. Engisch, Die Idee der Konkretisierung in Recht und Rechtswissenschaft unserer Zeit, 2. ergänzte Auflage, Heidelberg, 1968.

K. Engisch, Begriffseinteilung und Klassifikation in der Jurisprudenz, in: G. Paulus, U. Diederichsen, C.W. Canaris, Festschrift für Karl Larenz zum 70. Geburtstag, München 1973, 125-153.

$J$. Esser, Grundsatz und Norm in der richterlichen Fortbildung des Privatrechts, 4. Auflage, Tübingen, 1990.

Europees Parlement, Thesaurus Eurovoc, Deel 3: Meertalige versie, derde uitgave, Luxemburg, 1995.

M. Ferid, K. Firsching, Internationales Erbrecht, Band II-V, München (Loseblattausgabe).

W. Fikentscher, Methoden des Rechts in vergleichender Darstellung, Band III: Mitteleuropäischer Rechtskreis, Tübingen, 1976. 
Firsching/

won Hoffmann

Fischer 1973

Fischer 1977

Florijn

Frändberg

Franken

Fratcher

Friedman

Gadamer

Gamillscheg

Gemeenschappelijke Onderwerpsontsluiting
K. Firsching, B. von Hoffmann, Intemationales Privatrecht, 4. neubearbeitete Auflage, München, 1995.

J. Fischer, Library of Congress Classification. Law of the United Kingdom and Ireland. KD, Washington, 1973.

J. Fischer, Library of Congress Classification. Law (General). $\mathrm{K}$, Washington, 1977.

N.A. Florijn, Rechtsvergelijking in het wetgevingsproces, diss., Zwolle, 1993.

A. Frändberg, An essay on the systematics of legal concepts, Scandinavian studies in law 1987, 83-115.

H. Franken, InLeiden tot de rechtswetenschap, 7e druk, Arnhem, 1995.

W.F. Fratcher, Trust, Chapter 11 of Volume VI in: International Encyclopedia of Comparative Law, Tübingen/The Hague/Paris, 1973.

L.M. Friedman, Law and society, Englewood Cliffs, 1977.

H:-G. Gadamer, Wahrheit und Methode, 4. Auflage, Tübingen, 1975.

F. Gamillschegg, Überlegungen zur Methode der Qualifikation, in: H.-M. Pawlowski, F. Wieacker, Festschrift für Karl Michaelis, Göttingen 1972, 79-99.

Werkgroep Gemeenschappelijke Onderwerpsontsluiting en Commissie Basisclassificatie, Nederlandse basisclassificatie, tweede herziene uitgave, Leiden, 1992. 
Gessner

V. Gessner, Überlegungen zu einer Soziologische Theorie der angewandten Rechtsvergleichung, in: U. Drobnig, M. Rehbinder, Rechissoziologie und Rechtsvergleichung, Berlin 1977, 123-150.

van Ginsbergen 1968 G. van Ginsbergen, Het kwalificatieprobleem van het internationaal privaatrecht voor rechter en vertaler, Nederlands Juristenblad 1968, 353-359.

van Ginsbergen 1970 G. van Ginsbergen, Qualifikationsproblem, Rechtsvergleichung und mehrsprachige Staatsverträge, Zeitschrift für Rechtsvergleichung $1970,1-15$.

Glastra van Loon J.F. Glastra van Loon, Norm en handeling, diss., Haarlem, 1956.

Gödan 1986

J.C. Gödan, Legal comparativists and computerized legal information systems. General problems and the present German status of computerized legal information, International journal of legal information 1986, 1-49.

Gödan 1991

J.C. Gödan, Dreißig Thesen zur rechtsbibliographischen Technik und Methode, in: J.C. Gödan, H. Knudsen, Bibliothek und Recht - international, Hamburg/Augsburg 1991, 77-93.

Gödan 1992

J.C. Gödan, International legal bibliographies, Ardsley-on-Hudson, 1992.

Gödert

Goldberg 1977

W. Gödert, Bibliothekarische Klassifikationstheorie und on-line-Kataloge, Bibliothek. Forschung und Praxis 1987, 152-166.

J.E. Goldberg, Klassifizierung des deutschen Rechts bei der Library of Congress, Mitteilungen der Arbeitsgemeinschaft für juristisches Bibliotheks- und Dokumentationswesen 1977, 47-61, 99-116.

Goldberg 1981a

J.E. Goldberg, Sacherschließung deutscher juristischer Literatur an der Library of Congress, Mitteilungen der Arbeitsgemein- 
Goldberg $1981 \mathrm{~b}$

Goldberg 1981c

Goldberg 1982

Goldberg 1985

Goldberg 1986

Goldberg 1987

Goldberg 1989

Goldberg 1993

Goldberg 1994

Griffiths schaft für juristisches Bibliotheks- und Dokumentationswesen $1981,51-73$.

J.E. Goldberg, Classification of German Law at the Library of Congress. A Study in Comparative Law, International Journal of Law Libraries $1981,145-161$.

J.E. Goldberg, Library of Congress Classification System for German Law. A New Approach, Law Library Journal 1981, 619-631.

J.E. Goldberg, Library of Congress Classification. Law of Germany. KK-KKC, Washington, 1982.

J.E. Goldberg, Library of Congress Classification. Law of France. KJV-KJW, Washington, 1985.

J.E. Goldberg, Library of Congress Class KK. Law of Germany. A Historical Review of Law Classification, in: $G$. Hahn, $H$. Kirchner, Parlament und Bibliothek, München/London/New York/Oxford/Paris 1986, 328-344.

J.E. Goldberg, Library of Congress Law Classification. The Regional Schedules, Law Library Journal 1987, 67-91.

J.E. Goldberg, Library of Congress Classification. Law of Europe. KJ-KKZ, Washington, 1989.

J.E. Goldberg, Library of Congress Classification. Law of Asia and Eurasia, Africa, Pacific Area, and Antarctica. KL-KWX, Volume I, Washington, 1993.

J.E. Goldberg, Library of Congress Class $K$ for Law, in: R.A. Danner, M.-L. H. Bernal, Introduction to Foreign Legal Systems, New York/London/Rome 1994, 347-357.

J. Griffiths, Is law important?, oratie, Deventer, 1978. 
Groeneveld

Groll 1974a

Groll $1974 b$

de Groot 1979

de Groot 1987

de Groot 1988a

de Groot 1988b

de Groot 1989

de Groot 1990a

de Groot 1990b
C. Groeneveld, Over de grondslagen van de classificatietheorie, Bibliotheeklleven 1954, 221-248.

H. Groll, Considerations relating to the compilation of a legal thesaurus in German, International Journal of Law Libraries $1974,13-19$.

H. Groll, Zur Frage eines internationalen Rechtsthesaurus. Bericht über ein Treffen von Rechtsbibliothekaren in Grenoble, Mitteilungender Arbeitsgemeinschaft für juristisches Biblliotheksund Dokumentationswesen 1974, 28-31.

G.-R. de Groot, Enkele opmerkingen over het islamitische recht, in het bijzonder over islamitische huwelijkscontracten, Weekblad voor privaatrecht, notariaat en registratie 1979, 341-343; 361-367.

G.-R. de Groot, Het vertalen van juridische teksten, in: J.P. Balkema, G.-R. de Groot, Recht en vertalen, Deventer 1987, 13-36.

G.-R. de Groot, Aantekeningen over indeling van rechtsstelsels in rechtsfamilies, in: Eenheid en verscheidenheid van rechtsculturen en rechtssystemen, Maastricht 1988, 7-18.

G.-R. de Groot, Staatsangehörigkeitsrecht im Wandel, diss. , Den Haag, 1988.

G.-R. de Groot, Vergelijkt alles en behoudt het goede, oratie, Deventer, 1989.

G.-R. de Groot, Een nieuw tweetalig juridisch woordenboek, De Juridische Bibliothecaris 1990, 21-27.

G.-R. de Groot, Die relative Äquivalenz juristischer Begriffe und deren Folge für mehrsprachige juristische Wörterbücher, in: M. Thelen; B. Lewandowska-Tomaszczyk, Translation and Meaning, Part 1, Maastricht 1990, 122-128. 
de Groot/Medendorp A.D. de Groot, F.L. Medendorp, Term, begrip, theorie. Inleiding tot signifische begripsanalyse, Meppel, 1986.

de Groot/Rayar

G.-R. de Groot, L. Rayar, Dictionnaire juridique Navatre, European Review of Private Law 1995, 523-533.

de GrootSchneider G.-R. de Groot, H. Schneider, Das Werturteil in der Rechtsvergleichung, in: K. Boele-Woelki, F.W. Grosheide, E.H. Hondius, G.J.W. Steenhoff, Comparability and Evaluation, Dordrecht/Boston/London 1994, 53-68.

Grundmann

S. Grundmann, Qualifikation gegen die Sachnorm, München, 1985

Grunwald

W. Grunwald, Klassifikationstheorie, Zeitschrift für Bibliothekswesen und Bibliograplie 1968, 17-34.

Gusy

C. Gusy, "Wirklichkeit" in der Rechtsdogmatik, Juristenzeitung $1991,213-222$.

Gutteridge

H.C. Gutteridge, Comparative law, Cambridge, 1949.

Hage 1981

J.C. Hage, Over de betekenis van vage termen als "goede trouw", "redelijkheid" en "billijkheid", Weekblad voor privalrecht, notariaat en registratie $1981,708-710$.

Hage 1986

J.C. Hage, The Objectivity of Value Judgements, Rechtstheorie $1986,501-507$.

Hall

J. Hall, Comparative law and social theory, Baton Rouge, 1963.

Herberger/Simon M. Herberger, D. Simon, Wissenschaftstheorie für Juristen, Frankfurt am Main, 1980 .

Herbots

J.H. Herbots, Pleidooi voor de invoering in België van het fiduciecontract naar het trustnabootsende Franse model, Rechtskundig Weekblad 1993, 313-319. 
Heyn

Hill

van Hoecke

Hoppe

Houtart

Huppes

ISO

Jansen

Jennings/Watts

Jettinghoff

von Jhering

Joachim
H.-C. Heyn, Die "Dopppel-" und "Mehrfachqualifikation" im IPR, Diss., Frankfurt am Main, 1986.

J. Hill, Comparative Law, Law Reform and Legal Theory, Oxford Journal of Legal Studies 1989, 101-115.

M. van Hoecke, Aard en methode van de rechtsdogmatiek, Rechtsfilosofie en Rechtstheorie 1984, 188-205.

H. Hoppe, Die Qualifikation von Rechtssätzen, Berlin 1970.

E. Houtart, Le dictionnaire CREDOC, Cahiers de la documentation 1969, 15-19.

E.A. Huppes-Cluysenaer, Van een analytische naar een functionele rechtsopvatting (II), Rechtsfilosofie en Rechtstheorie 1981, 176-203.

International Organization for Standardization, Documentation * Guidelines for the establishment and development of multilingual thesauri, Genewa, 1985.

R. Jansen, Terminologische Kontrolle und Begriffsrelationen bei der Erstellung mehrsprachiger Thesauri, in: International scientific symposium on multilingual thesauri, Berlin 1973, 13-20.

R. Jennings, A. Watts, Oppenheim's international law, Volume I, ninth edition, Harlow, 1992.

A. Jettinghoff, Juristen en andere leken over rechtstaal en rechtspleging, Praktijkgids 1979, 386-389.

R. von Jhering, Geist des römischen Rechts, Teil 2 Abteilung 2 ,

9. Auflage, Aallen, 1968.

W.E. Joachim, The "Reasonable Man" in United States and German Commercial Law, The Comparative Law Yearbook of International Business 1992, 341-365. 
Jolowicz

Juynboll

Kaden

Kahn-Freund

Kamphuisen

Kant

Kaufmann

Kegel

Keller/Siehr

Kisch

Klaasse

KIug
J.A. Jolowicz, Fact based classification of law; in: J.A. Jolowicz, The division and classification of the law, London 1970 , $1-9$.

T.W. Juynboll, Handleiding tot de kemis van de mohammedaansche wet, Leiden, 1930.

E.-H. Kaden, Rechtswergleichung, in: F. Schlegelberger, Rechtsvergleichendes Handwörterbuch für das Zivil - und Handelsrecht des In- und Auslandes, Band 6, Berlin 1929-1940, 9-27.

O. Kahn-Freund, General problems of private international law, Alphen aan den Rijn/Rockville, 1980.

P.W. Kamphuisen, Beschouwingen over rechtswetenschap, Nijmegen/Utrecht, 1938.

I. Kant, Kritik der reinen Vernunft, Hamburg, 1956.

A. Kaufmann, Analogie und "Natur der Sache", 2. Auflage, Heidelberg/Hamburg, 1982.

G. Kegel, Internationales Privatrecht, 7. neubearbeitete Aullage, München, 1995.

M. Keller, K. Siehr, Allgemeine Lehren des internationalen Privatrechts, Zürich, 1986.

I. Kisch, Droit comparé et terminologie juridique, in: H.U. Jessurun d'Oliveira, Uitgelezen opstellen, Zwolle 1981, 206-217.

F. Klaasse, De informatieve waarde van titels van juridische tijdschriftartikelen, De Juridische Bibliothecaris 1986, 13-15.

U. Klug, Juristische Logik, 4. Auflage, Berlin/Heidelberg/New York, 1982. 
Knapp

Knoepfler/Schweizer

Kötz 1990

Kötz 1992

Kokkini 1985

Kokkini 1988a

Kokkini 1988b

Koopmans

Korevaar 1968

Korevaar 1974
V. Knapp "Legal thesauri, in: A.A. Martino, Deontic Logic, Computational Linguistics and Legal Information Systems, Volume Il, Amsterdam/New York/Oxford 1982, 267-290.

F. Knoepfler, P. Schweizer, Droit international privé suisse, $2 \mathrm{e}$ édition, Bern, 1995.

H. Kötz, Rechtsvergleichung und Rechtsdogmatik, Rabels Zeitschrift für ausländisches und internationales Privatrecht 1990, 203-216.

H. Kötz, A Common Private Law for Europe. Perspectives for the Reform of European Legal Education, in: B. De Witte, C. Forder, The common law of Europe and the future of legal education, Deventer 1992, 31-41.

D. Kokkini-Iatridou, Enkele methodologische aspecten van rechtsvergelijking. Het derde deel van een (pre-)paradigma, Deventer, 1985.

D. Kokkini-Iatridou, e.a., Een inleiding tot het rechtsvergelijkende onderzoek, Deventer, 1988.

D. Kokkini-latridou, The Tertium Comparationis in the Micro-Comparative Research, in: Institute of Comparative Law. Waseda University, Law in East and West. On the occasion of the 30th anniversary of the Institute of Comparative Law. Waseda University, Tokyo 1988, 231-242.

T. Koopmans, Vergelijkend publiekrecht, 2e druk., Deventer, 1986.

J.D. Korevaar, Review. Elisabeth Moys, A classification scheme for law books (1968), Bulletin of the International Association of Law Libraries 1968, 15-18.

J.D. Korevaar, UDC and legal literature, International Journal of Law Libraries 1974, 20-21. 
Kosters/Dubbink

J. Kosters, C.W. Dubbink, Algemeen deel van het Nederlandse internationaal privaatrecht, Haarlem, 1962.

Krause

Kreuzer

H.D. Krause, Creation of Relationships of Kinship, Chapter 6 of Volume IV in: International Encyclopedia of Comparative Law, Tübingen/The Hague/Paris, 1976.

K.F. Kreuzer, Die Klassifikation in rechtsvergleichenden Bibliotheken, Zeitschrift für vergleichende Rechtswissenschaft 1982 , 139-157.

Kropholler 1993

J. Kropholler, Europäisches Zivilprozeß recht, 4. neubearbeitete Auflage, Heidelberg, 1993.

Kropholler 1994 J. Kropholler, Internationales Privatrecht, 2. neubearbeitete Auflage, Tübingen, 1994.

Kuhlen 1976

$\mathbb{L}$. Kuhlen, Die Denkform des Typus und die juristische Methodenlehre, in: H.-J. Koch, Juristische Methodenlehre und analytische Philosophie, Kronberg/Ts. 1976, 53-69.

Kuhlen 1977

L. Kuhlen, Typuskonzeptionen in der Rechtstheorie, Berlin, 1977.

van Laer 1977

C.J.P. van Laer, Kan de redelijkheid van de wil van de wetgever een axioma zijn voor de rechtswetenschap?, Kennis en methode $1977,368-389$

van Laer 1978

C.J.P. van Laer, De "applicatio" bij H.-G. Gadamer, Algemeen Nederlands Tijdschrift voor Wijsbegeerte 1978, 245-266.

van Laer 1982

C.J.P. van Laer, UDC toegepast binnen LCC. De verenigbaarheid van twee universele classificaties, Open 1982, 147-155.

van Laer 1984

C.J.P. van Laer, Classeren van juridica in de Rijksuniversiteit Limburg, De Juridische Bibliothecaris 1984, 34-35. 
van Laer 1987a

van Laer $1987 b$

van Laer 1990

La Fontaine

Langridge

Lansky 1968

Lansky 1981

Lansky 1982

Lecheler

Ledig

Lehto
C.J.P. van Laer, Toegankelijkheid van juridische informatie middels gemeenschappelijke onderwerpsontsluiting, De Juridische Bibliothecaris 1987, 17-20.

C.J.P. van Laer, Co-referaat. Welke trefkans is gebruikersvriendelijk?, in: M.P. van Buijtenen, M.J. Schiltman, Onderzoek in bibliotheek-en informatiewetenschap, Den Haag 1987, 139-141.

C.J.P. van Laer, Demarcatie van functionele rechtsgebieden, Rechtsfilosofie en Rechtstheorie 1990, 100-108.

H. La Fontaine, Classification décimale universelle. 3: Sciences sociales, 5e édition, Bruxelles; 1952.

D.W. Langridge, Classification. Its kinds, elements, systems and applications, London/Melbourne/Munich/New York, 1992.

R. Lansky, Systematik der Rechtswissenschaft in Grundzügen, Bonn, 1968.

R. Lansky, Handbuch der Bibliographien zum Recht der Entwicklungsländer, Frankfurt am Main, 1981.

R. Lansky, Bibliothek des Schweizerischen Instituts für Rechtsvergleichung in Lausanne. Vorschlag zur Gliederung der Literatur, Mitteilungen der Arbeitsgemeinschaft für juristisches Bibliotheks- und Dokumentationswesen 1982, 25-30.

H. Lecheler, "Funktion" als Rechtsbegriff?, Neue Juristische Wochenschrift 1979, 2273-2277.

G. Ledig, Der Begriff als Instrument der Rechtspflege, Kant-Studien 1927, 320-329.

L. Lehto, Methodological aspects of legal translation, in: J. Tommola, K. Battarbee, Papers of the conference of departments of English in Finland, Turlin 1985, 147-176. 
Lemaire

Leser 1961

Leser 1981

Levontin

Linant de Bellefonds
W.L.G. Lemaire, Nederlands internationaal privaatrecht, Leiden, 1968.

H.G. Leser, Rezension. Index to Foreign Legal Periodicals, Archiv für die civilistische Praxis 1961, 459-461.

H.G. Leser, Juristische Bibliotheken und juristische Dokumentationen, Zeitschrift für vergleichende Rechtswissenschaft 1981 , 59-71.

A.V. Levontin, Choice of Law and Conflict of Laws, Leiden, 1976.

X. Linant de Bellefonds, L'utilisation d'un "système expert" en droit comparé, Revue internationale de droit comparé 1994, 703-718.

Lipstein

K. Lipstein, Trusts, Chapter 23 of Volume III in: International Encyclopedia of Comparative Law, Tübingen/Dordrecht/Boston/Lancaster, 1994.

Lloyd

J.J. Lloyd, Concept relations in a multilingual thesaurus, in: International scientific symposium on multilingual thesauri, Berlin 1973, 21-23.

Lohse

M. Lohse, Das Verhältnis von Vertrag und Delikt, Diss., München, 1991.

van Loon

J.H.A. van Loon, Anglo-Amerikaanse trusts en het Nederlandse recht. Aanrakingspunten met het Nederlandse recht, preadvies, Deventer, 1983.

Loth 1986

M.A. Loth, De anomalie van de rechtstaal, Rechtsfilosofie en Rechtstheorie 1986, 232-252.

Loth 1987

M.A. Loth, Taal en relativisme, Recht en kritiek 1987, 355-372.

Loth 1990
M.A. Loth, De geest van Begriffsjurisprudenz, Rechtsgeleerd magazijn Themis $1990,3-12$. 
Loth 1991

Mackaay

Makarov

Margrave

Mayer

Mazet 1986a

Mazet 1986b

McLelland

McVeigh

Mehl

Meier

Meijers 1948
M.A. Loth, Recht en taal, $2 e$ druk, Arnhem, 1991.

E. Mackaay, La création d'un Thésaurus bilingue pour Datum, Revue juridique Themis 1971, 51-67.

A.N. Makarov, Theorie und Praxis der Qualifikation, in: E. von Caemmerer, A. Nikisch, K. Zweigert, Vom deutschen zum europäischen Recht. Festschrift für Hans Dölle, Band II, Tübingen 1963, 149-177.

C.V. Margrave-Jones, Mellows. The Law of Succession, fifth edition, London/Dublin/Edinburgh, 1993.

P. Mayer, Droit international privé, 5e édition, Paris, 1994.

G. Mazet, Les systèmes informatisés de documentation juridique. Leur utilisation dans les recherches de droit étranger, comparé et international, Revue internationale de droit comparé $1986,775-783$.

G. Mazet, JANUS ou conception et réalisation d'un instrument bilingue d'accès aux banques de données juridiques françaises et italiennes, Montpellier, 1986.

J. McLelland, Computers, databases and thesauri, Aslib Proceedings 1990, 201-205.

K. McVeigh, Reclassifying the Squire Law Library, Law Librarian $1984,48-49$.

L. Mehl, Informatique juridique et droit comparé, Revue internationale de droit comparé 1968, 617-627.

A. Meier-Hayoz, Berner Kommentar, Band IV: Das Sachenrecht, 1. Abteilung: Das Eigentum, 1. Teilband: Systematischer Teil und Allgemeine Bestimmungen, 5: Auflage, Bern, 1981.

E.M. Meijers, De Algemene Begrippen van het Burgerlijk Recht, Leiden, 1948. 
Meijers 1972

Mellema

Mertens

Mertens/van der Merwe

van der Merwe

Meyer

Mills

Mincke 1984

Mincke 1987

Mincke 1991

Mincke 1993
E.M. Meijers, Ontwerp voor een Nieuw Burgerlijk Wetboek. Toelichting vierde gedeelte, 's-Gravenhage, 1972.

T.J. Mellema-Kranenburg, De legitieme portie, diss., Deventer, 1988.

R.F.H. Mertens, Appartementsrecht en de welstandsbepalingen, diss., Deventer, 1989.

R.H.F. Mertens, C.G. van der Merwe, Besluitvorming in de gemeenschap van appartementseigenaars, Weekblad voor privaatrecht, notariaat en registratie 1994, 275-281.

C.G. van der Merwe, Appartment Ownership. Chapter 5 of Volume VI in: International Encyclopedia of Comparative Law, Tübingen/Dordrecht/Boston/Lancaster, 1994.

W. Meyer-Sparenberg, Staatsvertragliche Kollisionsnormen, Diss., Berlin, 1990.

J. Mills, A modern outline of library classification, second impression, London, 1960.

W. Mincke, Eine vergleichende Rechtswissenschaft, Zeitschrift für vergleichende Rechtswissenschaft 1984, 315-328.

W. Mincke, Vertalen binnen een tweetalig rechtssysteem (Finland), in: J.P. Balkema, G.-R. de Groot, Recht en vertalen, Deventer 1987, 103-112.

W. Mincke, Die Problematik von Recht und Sprache in der Übersetzung von Rechtstexten, Archiv für Rechts- und Sozialphilosophie 1991, 446-465.

W. Mincke, Verständlichkeit und Verstehen im Recht, in: S. Erlinghagen, D. Geck, A. Junker, R. Schmitz, "Die Freuden des jungen Bäckermeisters Lehmann", Münster 1993, 159-177. 
Moys 1968

Moys 1976

Moys 1982

Moys 1992

Nagy

Neuhaus

Neville

Niederer

Norreklit

North/Fawcett

Palstra 1969a

Palstra $1969 b$
E.M. Moys, A classification scheme for law books, Londion, 1968.

E.M. Moys, Classification, in: E.M. Moys, Manual of Law Librarianship, London 1976, 548-580.

E.M. Moys, Moys Classification Scheme for Law Books, second edition $_{i}$ London, 1982.

E.M. Moys, Moys classification and thesaurus for legal materials, third edition, London/Melbourne/Munich/New York, 1992.

L. Nagy, Reform Efforts in the Universal Decimal Classification of the Legal and Administrative Sciences, International Forum on Information and Documentation 1979, 31-32.

Nederlandse Classificatie Stichting, Criteria voor een classificatie, Den Haag, 1987.

P.H. Neuhaus, Die Grundbegriffe des internationalen Privatrechts, 2. Auflage, Tübingen, 1976 .

H.H. Neville, Thesaurus reconciliation, Aslib proceedings 1972 , 620-626.

W. Niederer, Die Frage der Qualifikation als Grundproblem des internationalen Privatrechts, Nendeln/Liechtenstein, 1977.

L. Norreklit, Concepts, Odense, 1973.

P.M. North, J.J. Fawcett, Cheshire and North's private international law, twelfth edition, London/Dublin/Edinburgh, 1992.

J.T.M. Palstra, Het Computerproject "Goede trouw". Ervaringen en conclusies, Nederlands Juristenblad 1969, 997-1004.

J.T.M. Palstra, De computer als hulpmiddel bij de juridische documentatie, Ars Aequi 1969, 461-467. 
Pawlowski

van Peursen

Pierard

Plato

Popper

van Praag

Raape/Sturm

Rabel 1931

Rabel 1958

Raming

Rayar

van Reenen 1995
T. Pawlowski, Begriffsbildung und Definition, Berlin/New York, 1980.

C.A. van Peursen, Het model in wijsgerig perspectief, Wijsgerig perspectief $1965,205-220$.

J.-P. Pierard, La classification traditionnelle dans les bibliothèques de droit comparé et l'impact de l'informatique dans celles-ci, in: W.J. Ganshof van der Meersch, Rapports belges au Xle Congrès de l'Aca-démie internationale de droit comparë, Anvers/Bruxelles 1982, 833-852.

Plato, Sämtliche Werke, Band 4, Hamburg, 1958.

K.R. Popper, Logik der Forschung, zehnte verbesserte und vermehrte Auflage, Tübingen, 1994.

L. van Praag, Bijdrage tot de leer der kwalificaties in het internationaal privaatrecht, Rechtsgeleerd Magazijn Themis 1939, 525-548.

L. Raape, F. Sturm, Internationales Privatrecht, Band I: Allgemeine Lehren, 6. Auflage, München, 1977.

E. Rabel, Das Problem der Qualifikation, Rabels Zeitschrift für auslän-disches und internationales Privatrecht 1931, 241-288.

E. Rabel, The conflict of laws, Volume I: Introduction. Family Law, second edition, Ann Arbor, 1958.

J.C.F. Raming, Terugvinden van juridische informatie bij een gestaag groeiend voiume, Deventer, 1996.

L. Rayar, Het vertalen van het Wetboek van Strafrecht. Aanzet tot een methodologie, in: G.-R. de Groot, Recht en vertalen II, Deventer 1993, 63-87.

T.P. van Reenen, Major theoretical problems of modern comparative legal methodology (1). The nature and role of the "tertium 
van Reenen 1996

Reynolds

Reynolds/Kenefick/

Durkin

Rheinstein

Riesthuis/Wijnands

Rigaux 1956

Rigaux 1978

Rigaux 1984

Rigaux 1987

Rigaux 1989

Ritzmann comparationis", Comparative and international law journal of Southern Africa 1995, 175-199.

T.P. van Reenen, Major theoretical problems of modern comparative legal methodology (3). The criteria employed for the classification of legal systems, Comparative and international law journal of Southern Africa 1996, 71-99.

T.H. Reynolds, Legal Indexing on an International Scale, Australian law librarian 1995, 134-143.

T.H. Reynolds, M.L. Kenefick, R.K. Durkin, Index to Foreign Legal Periodicals. Cumulation, Berkeley (annual).

M. Rheinstein, Einführung in die Rechtsvergleichung, 2. Auflage, München, 1987.

G. Riesthuis, G. Wijnands, Thesaurusbouw, Den Haag, 1992.

F. Rigaux, La théorie des qualifications en droit international privé, Bruxelles, 1956.

F. Rigaux, Le droit comparé comme science appliquée, Revue de Droit international et de Droit comparé 1978, 65-77.

F. Rigaux, Les notions à contenu variable en droit international privé, in: C. Perelman, R. Vander Elst, Les notions à contenu variable en droit, Bruxelles 1984, 237-249.

F. Rigaux, Droit international privé, Tome l: Théorie Générale, 2e édition, Bruxelles, 1987.

F. Rigaux, Les situations juridiques individuelles dans un système de relativité générale, Recueil des cours de l'Académie de Droit International $1989,9-407$.

U.J. Ritzmann, Über den Feststellungsvertrag, Diss., Hamburg, 1973. 
Robertson

Rodríguez Molinero

Rottleuthner

Rozmaryn 1958

Rozmaryn 1973

Sacco

Salomon

Samuel

Samuel/Rinkes

Sandrock

Sarcevic

Sartori
A.H. Robertson, Characterization in the conflict of laws, Cambridge, 1940 .

M. Rodriguez Molinero, System und Systembildung in Recht und Rechtswissenschaft, in: W. Schreckenberger, C. Starck, Praktische Vernunft, Gesetzgebung und Rechtswissenschaft, Stuttgart 1993, 122-127.

H. Rottleuthner, Rechtstheorie und Rechtssoziologie, Freiburg/München, 1981.

S. Rozmaryn, Communication du Professeur Stefan Rozmaryn, Revue internationale de droit compare 1958, 70-75.

S. Rozmaryn, Les grandes controverses du droit comparé, in: M. Rotondi, Buts et méthodes du droit comparé, Padova/New York 1973, 577-591.

R. Sacco, La comparaison juridique au service de la connaissance du droit, Paris, 1991.

R. Salomon, Het qualificatieprobleem in het international privaatrecht, diss., Amsterdam, 1933.

G. Samuel, System und Systemdenken - Zu den Unterschieden zwischen kontinentaleuropäischem Recht und Common Law, Zeitschrift für Europäisches Privatrecht 1995, 375-397.

G. Samuel, J. Rinkes, Contractual and non-contractual obligations in English law, diss., Nijmegen, 1992.

O. Sandrock, Über Sinn und Methode zivilistischer Rechtsvergleichung, Frankfurt am Main/Berlin, 1966.

S. Sarcevic, Conceptual Dictionaries for Translation in the Field of Law, International Journal of Lexicography 1989, 277-293.

G. Sartori, Social science concepts, Beverly Hills/London/New Delhi, 1984. 
Sauveplanne 1974 J.G. Sauveplanne, Conclusion, in: J.G. Sauveplanne, Security over corporeal movables, Leiden 1974, 293-303.

Sauveplanne 1975a J.G. Sauveplanne, De methoden van privaatrechtelijke rechtsvergelijking, Deventer, 1975.

Sauweplanne 1975b J.G. Sauveplanne, Rechtsstelsels in vogelvlucht, Deventer, 1975.

Sauveplanne 1981 J.G. Sauveplanne, Rechtsstelsels in vogelvlucht, tweede druk, Deventer, 1981.

Sauveplanne 1982 J.G. Sauveplanne, New Trends in the Doctrine of Private International Law and Their Impact on Court Practice, Recueil des cours de l'Académie de Droit International 1982, 9-98.

Sauveplanne 1989 J.G. Sauveplanne, Elementair internationaal privaatrecht, 9e druk, Deventer, 1989.

van Schendel

W.A.M. van Schendel, Vertegenwoordiging in privaatrecht en bestuursrecht, diss., Deventer, 1982.

Schiller 1948

A.A. Schiller, Address. Proceedings of forty-first annual meeling, Law Library Journal 1948, 265-276.

Schiller 1964

A.A. Schiller, Foreign Law Classification in the Columbia University Law Library, revised edition, Dobbs Ferry, 1964.

Schlosshauer

S. Schlosshauer-Selbach, Internationales Privatrecht, Heidelberg, 1989.

Schmidt

G.E. Schmidt, Sterke en zwakke adopties, diss., Den Haag, 1996.

Schön

H.G. Schön, Book reviews. Classification. Class K. Law (General). Draft (1976), International Classification 1977, 109.

Schöpping/Weyers J. Schöpping, G.R. Weyers, Contextgebonden elektronisch juridisch woordenboek, in: G.-R. de Groot, Recht en vertalen II, Deventer 1993, 89-109. 
Scholten

Schuck

Schurig

Schuyt 1981

Schuyt 1986

Schwab

Schwander

Schwimann

Schwind

Siddiqui

Sieverts/Groeneveld/Hofstede

Snijders
P. Scholten, Mr. C. Asser"s Handleiding tot de beofening van het Nederlands burgerlijk recht. Algemeen deel, derde druk, Zwolle, 1974.

H.J. Schuck, Linguistic aspects in the translation of thesauri, in: Third European Congress on Information Systems and Networks, Volume 1, München 1977, 447-462.

K. Schurig, Kollisionsnorm und Sachrecht, Berlin, 1981 .

C.J.M. Schuyt, Recht en samenleving, Assen, 1981.

C.J.M. Schuyt, Filosofie van de sociale wetenschappen, Leiden, 1986.

W.J. Schwab, La réalisation du thésaurus-s et du thésaurus-g, Revue juridique Thémis 1971, 69-83.

I. Schwander, Einführung in das internationale Privatrecht, Band I: Allgemeiner Teil, 2. Auflage, St. Gallen, 1990.

M. Schwimann, Internationales Privatrecht, Wien, 1993.

F. Schwind, Systembegriff und Funktionsbegriff, in: N. Horn, Europäisches Rechtsdenken in Geschichte und Gegenwart, Band II, München 1982, 483-494.

M. Siddiqui, Mahr. Legal obligation or rightful demand?, Journal of Islamic Studies 1995, 14-24.

E.G. Sieverts, C. Groeneveld, M. Hofstede, Microcomputerprogrammatuur voor documentatie en bibliotheek, Den Haag, 1992.

W. Snijders, Trustverdrag en Nederlands materieel recht, in: Grensoverschrijdend privaatrecht, Deventer 1993, $231-243$. 
Somers

Speck

Steindorff

Steiner 1973a

Steiner $1973 b$

Steiner 1974a

Steiner $1974 b$

Steiner 1977

Steiner 1981

Steiner 1982
H.L. Somers, Observations on Standards and Guidelines Concerning Thesaurus Construction, International Classification 1981, 69-74.

J. Speck, Handbuch wissenschaftstheoretischer Begriffe, Band 1, Göttingen, 1980.

E. Steindorff, Sachnormen im internationallen Privatrecht, Frankfurt am Main, 1958.

W.A.F.P. Steiner, Review. Dewey decimal classification (1971) Law, Law Librarian 1973, 14-15.

W.A.F.P. Steiner, Problems and possibilities of indexing legal periodical literature in the international field, International Journal of Law Libraries 1973, 49-61.

W.A.F.P. Steiner, Thesaurus problems as exemplified by the Index to Foreign Legal Periodicals, International Journal of Law Libraries $1974,5-13$.

W.A.F.P. Steiner, Classification scheme and list of subject headings for the Squire Law Library of the University of Cambridge, Dobbs Ferry, 1974.

W.A.F.P. Steiner, The possibility and limits of the unification of methods of using computers in the field of law. Rapports généraux au IXe Congrès international de Droit comparé, Bruxelles $1977,849-863$.

W.A.F.P. Steiner, Grundprobleme bei der Klassifikation der Rechtsliteratur in Bibliotheken, in: R. Lansky, Zur Klassifikation der Rechtsliteratur in der Bundesrepublik Deutschland, Hamburg/Augsburg 1981, 115-122.

W.A.F.P. Steiner, Some Problems of Classification in International and Comparative Law, International journal of legal information 1982, 320-325. 
Steiner 1991

Stepan

Stern

Stöcker

Stone

Storme

Striewe

Strikwerda

Svenonius 1979

Svenonius 1983

Szladits
W.A.F.P. Steiner, The Squire law library of the university of Cambridge, in: J.C. Gödan, H. Knudsen, Bibliothek und Recht - international, Hamburg/Augsburg 1991, 243-294.

J Stepan, A new classification of law for a foreign, comparative, and international research law library, Vanderbilt journal of transnational law 1983,557-582.

W.B. Stern, Comparative Law. The History of the Language Problem and the Use of Generic Terms, Law Library Journal $1962,300-310$.

O.M. Stöcker, Die "Eurohypothek", Díss., Berlin, 1992.

P. Stone, Conflict of laws, London/New York, 1995.

M. Storme, Data processing as applied to the law. CREDOC, a Beigian experiment. Rapports belges au Xe Congrès international de droit comparé, Bruxelles 1978, 677-683.

P. Striewe, Ausländisches und internationales Privatrecht der nichtehelichenLebensgemeinschaft, Köln/Berlin/Bonn/München, 1986.

L. Strikwerda, Inleiding tot her Nederlandse internationaal privaatrecht, vierde druk, Groningen, 1995.

E. Svenonius, Translation between hierarchical structures. An exercise in abstract classification, in: A. Neelameghan, Ordering systems for global information networks, Den Haag 1979 , 204-211.

E. Svenonius, Use of Classification in Online Retrieval, Library resources and technical services 1983, 76-80.

C. Szladits, Classification in a Comparative Law Library, American Journal of Comparative Law; Supp. 1982, 575-582. 
Tapper

Tsouyopoulos

Uniken Venema

Vegter

Verheul

Vischer

Vlas

Voorbij

Voskamp

Vranken

de Vries
C. Tapper, The retrieval of legal information by computer, in:

F. de Graaf, Computer en recht, Deventer 1972, 45-54.

N. Tsouyopoulos, Die Entdeckung der Struktur komparativer Begriffe in der Antike, Archiv für Begriffsgeschichte 1970 , 152-171.

C. AE. Uniken Venema, Het Haagse Trustverdrag. De in het verdrag voorziene "externe werking" van Anglo-Amerikaanse trusts, Weekblad voor privaatrecht, notariaat en registratie 1993, 362-369.

J. B. Vegter, Een kleine rechtsvergelijking, Weekblad voor privaatrecht, notariaat en registratie $1993,612-613 ; 629-631$.

J.P. Verheul, Rechtsvinding in thet internationaal privaatrecht, Amsterdam, 1973.

F. Vischer, A. von Planta, Internationales Privatrecht, 2. Auflage, Basel/Frankfurt am Main, 1982.

P. Vlas, Over hypotheken op in het buitenland gelegen onroerend goed, in: A.A. van Velten, J.F. Visser, D.C. Hannema, M.H.G. Rempt, 85 jaar Nederlandse Vereniging van Hypotheekbanken, Deventer 1991, 239-253.

H. Voorbij, Thesaurusproblematiek. Definitie, terminologie en functie, Open 1980, 198-205.

E. Voskamp, CREDOC en LEXIS. Documentatiesystemen ter ontsluiting van juridische literatuur, Informatie 1975, 316-326.

J.B.M. Vranken, Mr. C. Asser's Handleiding tot de beoefening van het Nederlands burgerlijk recht. Algemeen deel, Zwolle, 1995.

G. de Vries, De ontwikkeling van wetenschap, 3e herziene druk, Groningen, 1995. 
Wähler

van Waelsden

van de Walle

Wank

Weber

van der Wees

Weinberg

Wengler

Wersig

Weston

de Wild

Wittgenstein
K. Wähler, Zum Problem der Vergleichbarkeit sozialistischer und nichtsozialistischer Ptivatrechtsordnungen, in: G. Gutmann, S. Mampel, Probleme systemvergleichender Betrachtung, Berlin $1986,207-227$.

P.B.J.M. van Waelsden, De juridische Thesaurus, De Juridische Bibliothecaris $1987,1-3$.

J. van de Walle, Ontsluiting van documentaire informatie an recht, in: I.C.W. Magillsen, W.E.C.A. Valkenburg, Recht en publikatie, Lelystad 1995, 45-56.

R. Wank, Die juristische Begriffsbildung, München, 1985.

H. Weber, Die Theorie der Qualifikation, Tübingen, 1986.

L. van der Wees, Expertsystemen en rechtsvergelijking, NVKI-Nieuwsbrief 1994, 119-120.

B.H. Weinberg, Library Classification and Information Retrieval Thesauri. Comparison and Contrast, Cataloging and Classification Quarterly 1995, 23-44.

W. Wengler, Die Qualifikation der materiellen Rechtssätze im internationalen Privatrecht, in: E. von Caemmerer, W. Hallstein, F.A. Mann, L. Raiser, Festschrift für Martin Wolff, Tübingen $1952,337-374$.

G. Wersig, Thesaurus Leitfaden, 2, ergånzte Auflage, München/New York/London/Paris, 1985.

M. Weston, An English Reader's Guide to the French Legal System, New York/Oxford, 1991.

A.H. de Wild, Juridische databanken, rechtsinformatica en rechtsvergelijking, Deventer, 1991.

L. Wittgenstein, Tractatus logico-philosophicus, Frankfurt am Main, 1969. 
Wróblewski

Zweigert 1960

Zweigert 1969

Zweigert 1973

Zweigert $1977 \mathrm{a}$

Zweigert $1977 \mathrm{~b}$

Zweigert/Kötz 1984

Zweigert/Kötz 1996

Zweigert/Puttfarken 1978
J. Wróblewski, Problem of incomparability in comparative law, Rivista internazionale di filosofia del diritto 1976, 92-109.

K. Zweigert, Zur Methode der Rechtsvergleichung, Studium Generale 1960, 193-200.

K. Zweigert, Rechtswergleichung, System und Dogmatik, in: K.A. Bettermann, A. Zeuner, Festschrift für Eduard Bötticher, Berlin 1969, 443-449.

K. Zweigert, Die "Praesumptio similitudinis" als Grundsatzvermutung rechtsvergleichender Methode, in: $\mathbf{M}$. Rotondi, Buts et méthodes du droit comparé, Milaan/Padua/New York 1973, 735-758.

K. Zweigert, Die soziologische Dimension der Rechtsvergleichung, in: U. Drobnig, M. Rehbinder, Rechtssoziologie und Rechtsvergleichung, Berlin 1977, 151-168.

K. Zweigert, Buchbesprechung. Constantinesco L.-J. Rechtsvergleichung, Band I: Einführung in die Rechtsvergleichung (1971); Band II: Die rechtsvergleichende Methode, Rabels Zeitschrift für ausländisches und internationales Privatrecht 1977 , $171-177$.

K. Zweigert, H. Kötz, Einführung in die Rechtsvergleichung, Band I: Grundlagen, 2. neubearbeitete Auflage, Tübingen, 1984.

K. Zweigert, H. Kötz, Einführung in die Rechtsvergleichung, 3. neubearbeitete Auflage, Tübingen, 1996.

K. Zweigert, H.-J. Puttfarken, Zur Vergleichbarkeit analoger Rechtsinstitute in verschiedenen Gesellschaftsordnungen, in: $\mathbf{K}$. Zweigert, H.-J. Puttfarken, Rechtsvergleichung, Darmstadt $1978,395-429$. 


\section{Curriculum vitae}

Conrad Jean Pierre van Laer werd op 1 september 1952 geboren in Venlo. In 1970 behaalde hij het diploma gymnasium B aan het Bisschoppelijk College te Roermond. Vervolgens studeerde hij rechtsgeleerdheid en filosofie aan de Katholieke Universiteit te Nijmegen waar hij zich specialiseerde in de rechtstheorie. In 1975 respectievelijk 1978 werden de doctoraalexamens rechtsgeleerdheid en filosofie met goed gevolg afgelegd. In 1979 en 1980 werkte hij als medewerker Algemene inleiding voor de rechtenfaculteit van Nijmegen. Nadien is hij als juridisch bibliothecaris verbonden aan de Universiteit Maastricht.

Sinds 1977 publiceert Coen van Laer regelmatig over juridische, wijsgerige en bibliothecaire onderwerpen. Hem werd de Victorine van Schaickprijs 1985 toegekend voor twee publicaties omtrent het door hem ontwikkelde juridische classificatiesysteem voor de Universiteitsbibliotheek. Vanaf 1990 is hij eindredacteur van het tijdschrift 'De Juridische Bibliothecaris'. 